\title{
FAU-USP
}

Dissertação de mestrado

\section{O papel da ideologia na expansão urbana: a questão econômica e os impactos socioambientais do Arco Metropolitano do Rio de Janeiro}

Ticianne Ribeiro de Souza

São Paulo 2015 


\section{Ticianne Ribeiro de Souza}

\section{O papel da ideologia na expansão urbana:}

a questão econômica e os impactos socioambientais do

Arco Metropolitano do Rio de Janeiro.

Dissertação apresentada à Faculdade de Arquitetura e Urbanismo da Universidade de São Paulo para obtenção do título de Mestre em Arquitetura e Urbanismo.

Área de Concentração: Planejamento Urbano e Regional, linha de pesquisa: Urbanismo e planejamento.

Orientador: João Sette Whitaker Ferreira 
AUTORIZO A REPRODUÇÃO E DIVULGAÇÃO TOTAL OU PARCIAL DESTETRABALHO, POR QUALQUER MEIO CONVENCIONAL OU ELETRÔNICO, PARA FINS DE ESTUDO E PESQUISA, DESDE QUE CITADA A FONTE.

E-MAIL DA AUTORA: ticianne.r4@gmail.com

Souza, Ticianne Ribeiro de

S729p O papel da ideologia na expansão urbana: a questão econômica e os impactos socioambientais do Arco Metropolitano do Rio de Janeiro / Ticianne Ribeiro de Souza. --São Paulo,2015. 212 p. : il.

Dissertação (Mestrado -Área de Concentração: Planejamento Urbano e Regional) - FAUUSP.

Orientador: João Sette Whitaker Ferreira

1.Planejamento territorial urbano - Rio de Janeiro (RJ) 2.Impactos ambientais (Aspectos sociais) 3.Ideologia 4.Rodovia 5.Expansão urbana 6.Arco metropolitano 7.Neodesenvolvimento

CDU711.4(815.31) 
Nome: Ticianne Ribeiro de Souza

Título: 0 papel da ideologia na expansão urbana: a questão econômica e os impactos socioambientais do Arco Metropolitano do Rio de Janeiro.

Dissertação apresentada à Faculdade de Arquitetura e Urbanismo da Universidade de São Paulo para obtenção do título de Mestre em Arquitetura e Urbanismo.

Área de Concentração: Planejamento Urbano e Regional, linha de pesquisa: Urbanismo e planejamento.

Aprovado em: 12 / 05 / 2015

Banca examinadora:

Prof. Dr.: João Sette Whitaker Ferreira Instituição: FAU - USP Julgamento: aprovada Assinatura:

Instituição: FAU - USP

Assinatura: Julgamento: aprovada Instituição: UFABC Prof. Dr.: Francisco de Assis Comarú Julgamento: aprovada Assinatura: 


\section{Agradecimentos:}

Ao final dessa jornada, agradeço imensamente

aos meus pais, que sempre me proporcionaram uma educação de excelência e, ao longo de toda a minha vida, foram exemplo de força de vontade, paciência, dedicação e perseverança;

aos meus irmãos, que sempre estiveram ao meu lado, me ajudaram nos momentos mais difíceis, foram e sempre serão parceiros de alegrias e de tristezas;

aos meus amigos, que me deram forças para continuar na minha jornada acadêmica, em especial Juliana Pan e Alice Amorim, que sempre estiveram disponíveis para me ouvir e me ajudar prontamente;

aos meus colegas do Núcleo de Assessoria, Planejamento e Pesquisa (NAPP), pelo apoio e, principalmente, pelo incentivo;

aos meus professores da Escola de Arquitetura e Urbanismo da Universidade Federal Fluminense (EAU-UFF), em especial a Glauco Bienenstein, que me orientou com esmero no meu trabalho final de graduação, e a Cristina Nacif, por, no momento certo, ter me dito, sem qualquer hesitação, ”vá para São Paulo";

aos meus colegas e professores da Instituto de Pesquisa e Planejamento Urbano e Regional, da Universidade Federal do Rio de Janeiro (IPPUR-UFRJ), em especial a Adauto Cardoso, por ter me orientado na monografia de especialização e por continuar me ajudando na minha pesquisa de mestrado;

aos meus colegas da pós graduação da Faculdade de Arquitetura e Urbanismo Universidade de São Paulo (FAU-USP), em especial Alex Rosa, João Taqueda e Patrícia Cordeiro, companheiros de angústias, mas também de almoços e de risadas;

aos meus professores da FAU-USP, em especial a Eduardo Nobre, por ter participado da minha banca de qualificação, expondo sua opinião franca e ótimas criticas construtivas;

aos funcionários da pós graduação da FAU-USP, em especial a coordenadora Maria Lucia Refinetti e os funcionários da pós graduação lsa e André, a quem tanto perturbei com milhões de questões nos últimos três anos e que sempre foram muito prestativos e gentis;

por fim mas, sem dúvida, não menos importante, ao meu caro orientador João Sette, pelo voto de confiança, pela grande dedicação, pela paciência e pelos conselhos que tornaram essa dissertação possível. 


\section{Resumo}

Em 2003 inicia-se uma mudança no cenário político brasileiro classificada por alguns autores como período neodesenvolvimentista. Nesse momento são retomadas políticas de estruturação territorial, pensadas em décadas anteriores no contexto do desenvolvimentismo, como por exemplo, o Arco Metropolitano do Rio de Janeiro (AMRJ). Entretanto, a decisão da construção de rodovias como esta ocorre pela ênfase na necessidade de crescimento econômico, não ficando claro e nem sendo amplamente debatido com a população, quais os impactos socioambientais negativos e quais setores serão favorecidos com tais empreendimentos.

Este trabalho analisa o papel da ideologia nas grandes obras viárias metropolitanas, através da influência do discurso neodesenvolvimentista na implementação do Arco Metropolitano do Rio de Janeiro.

Utilizando o conceito de ideologia definido por Marx e Engels (1989), analisamos a presença do discurso ideológico nas principais fontes governamentais de informação sobre o AMRJ, considerando seus aspectos econômicos, institucionais e socioambientais. Para estes autores, através da ideologia, a classe dominante legitima suas ideias, apresentando-as como justas, válidas e benéficas para toda a população.

Segundo a documentação oficial, o Arco tem como intuito viabilizar o escoamento da produção do Complexo Petroquímico do Rio de Janeiro (COMPERJ) pelo porto de Itaguaí, e diminuir o fluxo de veículos em importantes vias metropolitanas especialmente na Avenida Brasil e Ponte Rio - Niterói, ao criar uma nova possibilidade de rota para veículos que utilizam as referidas vias apenas como passagem para outros destinos que não a cidade do Rio de Janeiro. Contudo, assinalamos aqui os fatores que levaram à insignificante melhora de transito nessas vias após a inauguração do AMRJ. Além disso, apontamos que o COMPERJ provavelmente não usará a rodovia como forma principal de escoamento, dado que a Petrobrás está construindo seu próprio porto e estrada em localidade consideravelmente mais próxima que Itaguaí, em São Gonçalo.

No material analisado também é constante a divulgação dos benefícios do Arco quanto à criação de empregos e facilitação do acesso às áreas não urbanizadas da Região Metropolitana do Rio de Janeiro (RMRJ). No entanto, 98\% da quantidade propagandeada de empregos se baseia apenas na expectativa do crescimento industrial a longo prazo. Já a expansão da fronteira urbana implica em diversos impactos socioambientais negativos, 
como: agravamento dos problemas de infraestrutura existentes nos municípios cortados pelo arco; aumento de pressões antrópicas nas áreas de preservação ambiental; aumento da ocorrência de inundações; gentrificação de locais ocupados por pescadores artesanais; entre outros.

Desta forma, questionando os reais benefícios do Arco, percebemos que suas principais justificativas são apenas peças de um discurso ideológico. 0 Arco pode acarretar inúmeros problemas e poucas benesses à população de baixa renda fluminense. Ele beneficiará sobretudo o setor logístico e o setor industrial através da redução dos custos com deslocamento e da criação de oportunidades locacionais. Notamos assim, que o discurso do AMRJ deturpa os impactos sociais dessa nova rodovia e omite questões políticoeconômicas e socioambientais fundamentais para o debate da validade dessa obra. É, portanto, um discurso ideológico elaborado para camuflar o interesse de classes dominantes como interesse coletivo.

Palavras chaves: arco metropolitano; neodesenvolvimentismo; impactos socioambientais; planejamento territorial urbano; ideologia; rodovias; expansão urbana. 


\section{Title :}

The role of ideology in urban sprawl: the economic issue and the social and environmental impacts of the Metropolitan Ring Road of Rio de Janeiro (AMRJ)

\section{Abstract:}

In 2003 a change on the Brazilian political scene starts, some authors would describe it as the "new developmentalism" period. Therefore, some territorial structuring policies elaborated in previous decades within the "developmentalism" context returns, such as the Metropolitan Ring Road of Rio de Janeiro (AMRJ). However, the decision of whether or not to build constructions of that magnitude lays sole on the intense need for economic growth, leaving aside broad debates with the population in order to clarify its negative social and environmental impacts, in addition to which sectors will profit from such projects.

This master's thesis analyzes the role of ideology in large metropolitan highways works, through the influence of neodesenvolvimentista speech in the implementation of the Metropolitan Ring Road of Rio de Janeiro.

Using the concept of ideology defined by Marx and Engels (1989) this study analyzed the presence of ideological discourse in major governmental sources of information about the AMRJ considering its economic, institutional and social and environmental aspects. According to these authors, the use of ideology by the ruling class legitimizes their ideas presenting them as fair, valid and beneficial for the entire population.

As stated in the official documentation, this ring road purpose is to enable the distribution of the Petrochemical Complex of Rio de Janeiro's production (COMPERJ) via ltaguai's port, as well as reduce the vehicles's flow in the major metropolitan routes, especially on Avenida Brazil and Rio-Niterói bridge creating a new possibility route for vehicles that are only passing through the Rio de Janeiro city. However, we evinced here the factors that led to insignificant improvement of traffic in these routes after the inauguration of AMRJ. In addition, we pointed that the COMPERJ probably will not use this highway as a primary route since Petrobras is building its own road and port in a place closer than Itaguaí, in São Gonçalo.

The analyzed material also constantly publicizes the benefits of the Ring Road about a boost on job creation and the facilitation of access to non-urbanized areas of the 
Metropolitan Region of Rio de Janeiro (RMRJ). However, 98\% of the increased number of jobs advertised is based only on the expectation of a long-term industrial growth. As to the expansion of the urban frontier, it implies many social and environmental negative impacts, such as worsening of existing infrastructure problems in the municipalities slashed by this road; increased human pressures in the areas of environmental preservation; increased occurrence of floods; gentrification of places occupied by artisanal fishermen; etcetera.

Thus, questioning the real benefits of the AMRJ, we realized that its main justifications are just pieces of an ideological discourse. It can cause many problems and few handouts to the low-income population of Rio de Janeiro. The ring clearly benefits the logistics sector and the industrial sector by the reduction of transport costs and the creation of locational opportunities. We note as well that AMRJ's speech distorts the social impacts of this new highway and omits political, economic, social and environmental key issues to debate the validation of this project. It is therefore an ideological discourse designed to camouflage the interest of the ruling classes as a collective interest.

Keywords: metropolitan ring road; new developmentalism; social and environmental impacts; urban and territorial planning; ideology; highways; urban growth. 


\section{Lista de abreviaturas e siglas:}

AlE - Aparelhos ldeológicos do Estado

AMRJ - Arco Metropolitano do Rio de Janeiro

APA - Área de Proteção Ambiental

BNDES - Banco Nacional de Desenvolvimento Econômico e Social

BNH - Banco Nacional de Habitação

CEBRAP - Centro Brasileiro de Análise e Planejamento

CEPAL - Comissão Econômica para a América Latina e o Caribe

CEPERJ - Fundação Centro Estadual de Estatísticas, Pesquisas e Formação de Servidores Públicos do Rio de Janeiro

COMPERJ - Complexo Petroquímico do Rio de Janeiro

DER - Departamento de Estradas de Rodagem

FLONA - Floresta Nacional

FMl - Fundo Monetário Internacional

FUNDREM - Fundação para o Desenvolvimento da Região Metropolitana do Rio de Janeiro

IBGE - Instituto Brasileiro de Geografia e Estatística

PAC - Programa de Aceleração do Crescimento

PDAM - Plano Diretor do Arco Metropolitano

PDTU - Plano Diretor de Transporte Urbano

RIMA - Relatório de Impacto Ambiental

RMRJ - Região Metropolitana do Rio de Janeiro

RMSP - Região Metropolitana de São Paulo

SEOBRAS - Secretaria de Obras do estado do Rio de Janeiro

SETRANS - Secretaria de Transportes do estado do Rio de Janeiro

TSE - Tribunal Superior Eleitoral

UC - Unidade de Conservação 


\section{Lista de lmagens:}

Figura 1 - Queima de café em Santos, patrocinada pelo governo Vargas, nos anos 1930. Foto de Theodor Preising.

Figura 2 - Dados de saneamento básico no Brasil.

Figura 3 - Evolução da produção de petróleo e gás natural do Estado do Rio de Janeiro (1995-2000).

Figura 4 - Investimentos no setor industrial previstos pelo PAC na RMRJ.

Figura 5 - Principais rodovias e empreendimentos atendidos pelo AMRJ.

Figura 6 - Mapa do AMRJ e sua divisão por segmentos.

Figura 7 - Seções transversais do AMRJ.

Figura 8 - Novos acessos ao Arco Metropolitano.

Figura 9 - Municípios da Região Metropolitana do Rio de Janeiro.

Figura 10 - Diferença entre zoneamento do PDAM (à esquerda) e do PD de Seropédica.

Figura 11 - 0 AMRJ nas APAs de Nova lguaçu.

Figura 12 - Trecho do AMRJ sobre o zoneamento do PD de Duque de Caxias.

Figura 13 - Arco com só 35\% das obras do trecho 'C' concluídas em meados de 2011.

Figura 14 - Notícia sobre abandono de obras no trecho da DELTA.

Figura 15 - Canteiro de obra funcionando após inauguração do Arco.

Figura 16 - Passarela para pedestre sendo construída após a inauguração do Arco.

Figura 17 - 0 AMRJ e a RMRJ.

Figura 18 - Investimentos Previstos em 2011 nos "Empreendimentos Aderentes.

Figura 19 - Província Portuária da Baía de Sepetiba.

Figura 20 - Reportagem que ressalta os possíveis empregos gerados a partir da construção do ARMJ.

Figura 21 - PIB no Estado do Rio de Janeiro em 2012.

Figura 22 - Empregos previstos pelos investimentos do PAC na RMRJ.

Figura 23 - Qualidade de vida X empregos na indústria.

Figura 24 - Índice FIRJAN de Desenvolvimento Municipal das cidades cortados pelo AMRJ.

Figura 25 - Tempo habitual de deslocamento para o trabalho de pessoas que trabalham fora do domicílio e retornavam para seu domicílio diariamente (\%) em 2010.

Figura 26 - Manchete sobre manifestações contra o aumento da tarifa das barcas no Rio de Janeiro. 
Figura 27 - Manifestação em junho de 2013 no centro do Rio de Janeiro.

Figura 28 - Aspectos Ambientais dos meios de transporte.

Figura 29 - Carregamento atual dos eixos de transporte da RMRJ.

Figura 30 - Divisão modal das viagens motorizadas da RMRJ.

Figura 31 - Arco após inaugurado o trecho "C".

Figura 32 - 0 Arco e os vazios urbanos da Região Metropolitana.

Figura 33 - "Boom" imobiliário no entorno do Arco.

Figura 34 - Áreas desmatadas para extração mineral em Seropédica (surgimento entre 2006 e 2015).

Figura 35 - Precariedade atual dos municípios cortados pelo AMRJ.

Figura 36 - Rodovia Rio-Santos - Evolução percentual de residentes com rede geral de esgoto.

Figura 37 - Rodovia Rio-Santos - Evolução percentual de crianças que trabalham.

Figura 38 - Déficit habitacional relativo por componente.

Figura 39 - Evolução do déficit habitacional.

Figura 40 - Percentual de cobertura de uso do solo Agropastoril, Florestal e Urbano dos Municípios da área de influência do Arco Metropolitano em 2007.

Figura 41 - Extração ilegal de argila que abastecia obras do arco.

Figura 42 - Áreas desmatadas para extração mineral em Seropédica (surgimento entre 2008 e 2015).

Figura 43 - Entrada da área de extração mineral em Seropédica (local marcado na figura 42).

Figura 44 - Áreas desmatadas para extração mineral vinculada ao AMRJ.

Figura 45 - 0 acesso direto ao AMRJ da área desmatada marcada na figura 43.

Figura 46 - Áreas desmatadas para extração mineral.

Figura 47 - Notícia sobre o conflito envolvendo a rã.

Figura 48 - 0 Bichoduto durante a obra.

Figura 49 - Assoreamento em poça da Physalaemus Soaresi.

Figura 50 - Cartaz de divulgação da Audiência Pública "Impactos Ambientais da Construção do AMRJ”.

Figura 51 - Interferência do Arco no Rio Guandu e na sua faixa marginal de proteção.

Figura 52 - Unidades de Conservação listadas por proximidade ao AMRJ.

Figura 53 - Opções de traçado do Arco sobre FlONA Mário Xavier. 
Figura 54 - A trilha que abriga a maior rodovia do estado.

Figura 55 - Dinâmica de Uso de Solo.

Figura 56 - Pressão sobre as Unidades de Conservação.

Figura 57 - Divisão entre a rodovia e a APA do Rio D’Ouro, com edificações em locais planos.

Figura 58 - Passagem entre a APA Tinguazinho e a APA do Rio D'Ouro.

Figura 59 - Inexistência de barreiras entre o Arco Metropolitano e a APA da Pedra Lisa.

Figura 60 - Potencial poluidor dos empreendimentos alicerces e dos empreendimentos aderentes.

Figura 61 - A distribuição da receita da campanha de Sérgio Cabral nas eleições para governador do estado do Rio de Janeiro em 2006. 


\section{Sumário:}

Introdução

Capítulo 1 ldeologia, Neodesenvolvimentismo e os seus Impactos Socioambientais..... 17

1.1. Mito, Ideologia e Planejamento Urbano ........................................................................ 19

1.2. Do desenvolvimentismo ao neoliberalismo ..................................................................... 27

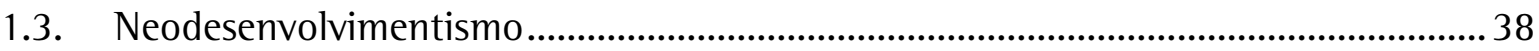

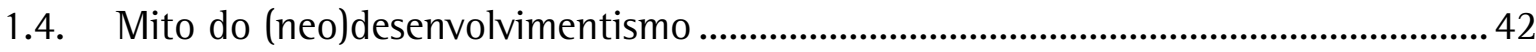

1.4.1. Neodesenvolvimentismo no contexto do capitalismo internacional .................. 44

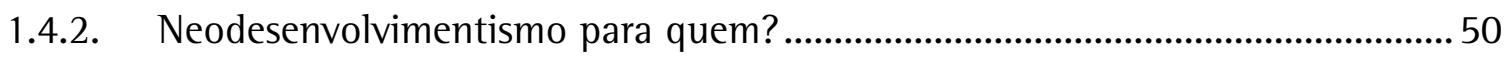

1.4.3. Neodesenvolvimentismo e a questão socioambiental........................................... 54

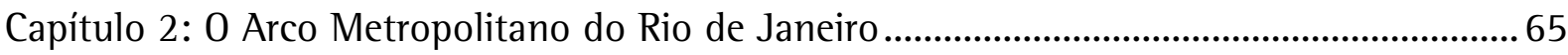

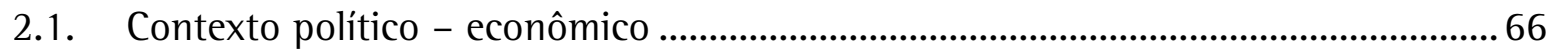

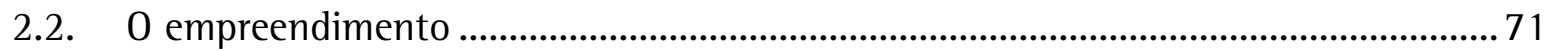

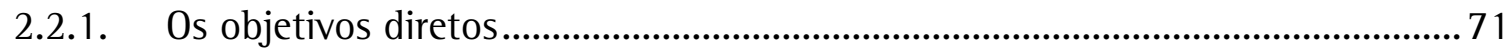

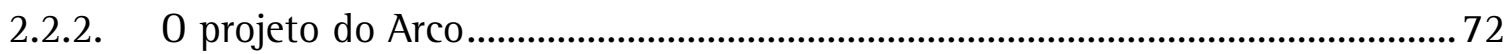

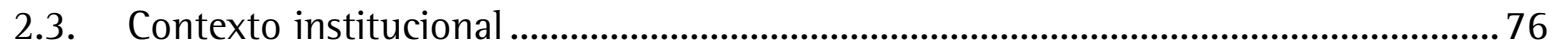

2.3.1. Planejamento de incongruências .............................................................................. 77

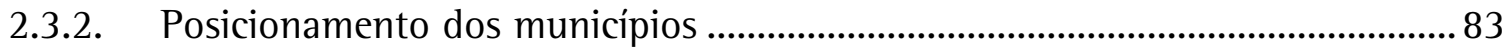

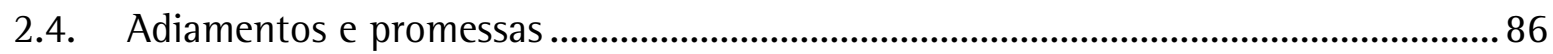


Capítulo 3: Principais justificativas e contradições do AMRJ: aspectos socioeconômicos, e a estruturação do território

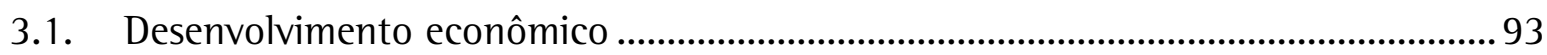

3.1.1. COMPERJ, porto de ltaguaí e empreendimentos aderentes............................... 93

3.1.2. A população local e suas atividades econômicas ................................................... 99

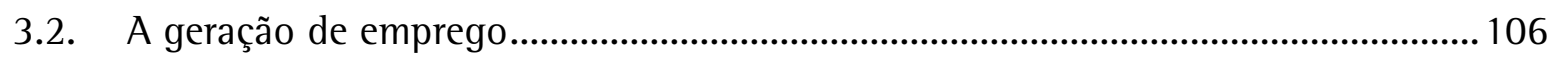

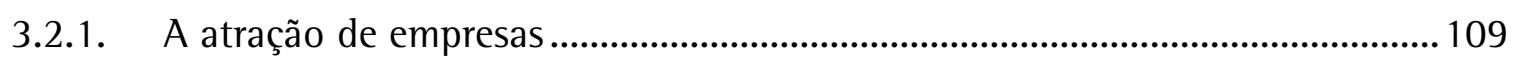

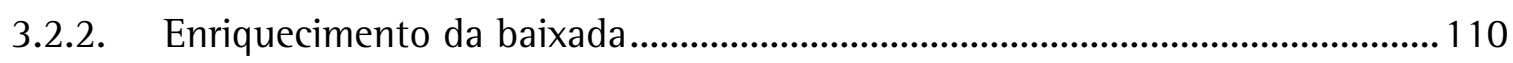

3.2.3. A criação de empregos de qualidade............................................................... 112

3.2.4. A criação de empregos e a melhoria da qualidade de vida .............................. 113

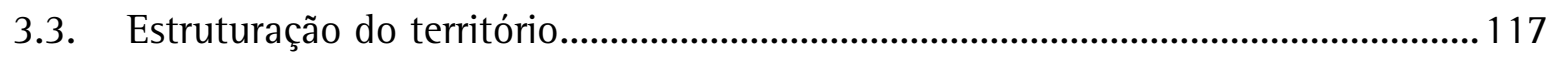

3.3.1. Mobilidade da RMRJ e a melhora do tráfego nas grandes vias....................... 119

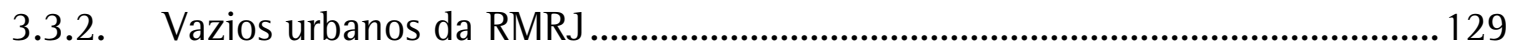

Capítulo 4: Impactos sobre a urbanização e o meio ambiente ............................................139

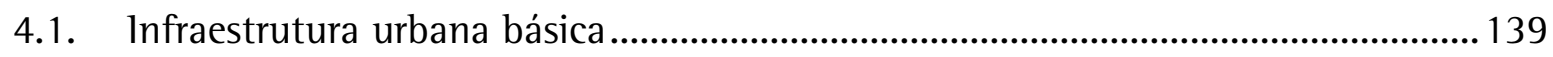

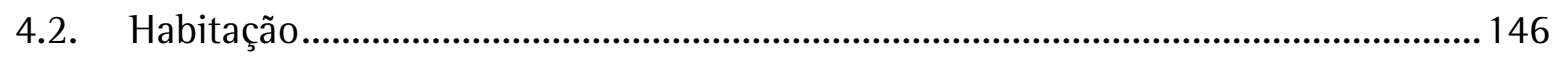

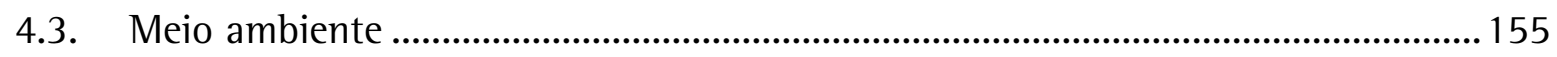

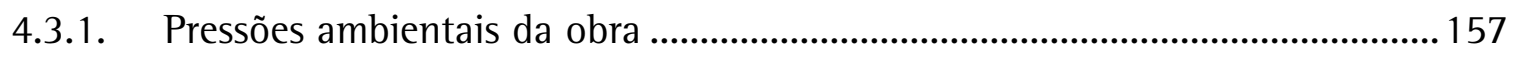

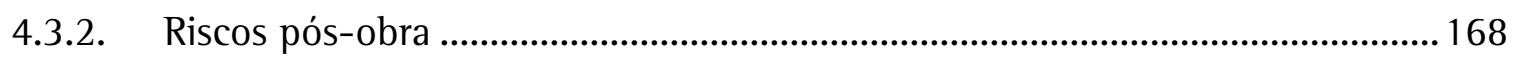

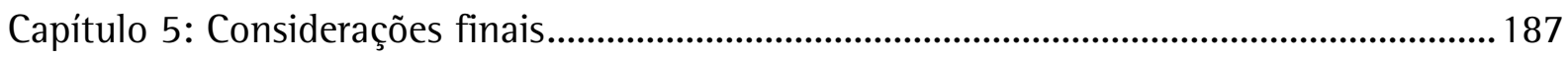

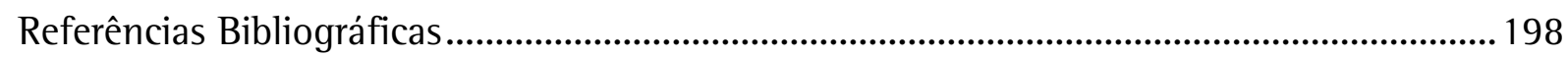




\section{lntrodução}

0 presente trabalho visa analisar a existência de um discurso ideológico no planejamento de grandes obras públicas rodoviárias brasileiras, com enfoque nos impactos socioambientais que decorrem desse tipo de empreendimento. Como estudo de caso, foi escolhido o Arco Metropolitano do Rio de Janeiro (AMRJ). Esta rodovia foi idealizada inicialmente em 1974, no contexto das políticas desenvolvimentistas iniciadas por Getúlio Vargas na década de 1930, e continuada pelo governo militar. No entanto, somente em 2007 o projeto do Arco Rodoviário começou a virar realidade, sendo incluído no Programa de Aceleração do Crescimento (PAC) do Governo Federal, que faz parte do período neodesenvolvimentista brasileiro. As obras foram finalizadas em novembro de 2014, no primeiro mandato da atual presidente Dilma Rousseff.

0 traçado do Arco corta oito municípios da Região Metropolitana do Rio de Janeiro (RMRJ). Com uma extensão de aproximadamente 145 quilômetros, a autopista interliga as cinco principais rodovias que atravessam a região, sendo dividida em quatro segmentos. Neste trabalho será analisado o empreendimento do ARMJ como um todo, mas focaremos no novo trecho de via correspondente ao segmento "C", já que os demais segmentos correspondem a rodovias existentes que passaram por reformas e/ou duplicação.

De acordo com as principais fontes governamentais de informação, o AMRJ é uma obra que se justifica fundamentalmente pelo intuito de atender à necessidade logística de ligação do Complexo Petroquímico do Rio de Janeiro (COMPERJ) com o Porto de Itaguaí, pelo qual a produção do COMPERJ será escoada. Nesse contexto, o Arco também é visto como viabilizador e estruturador do crescimento industrial na RMRJ.

Contudo, tanto a obra como o funcionamento de uma rodovia desse porte envolvem importantes questões socioambientais. 0 segmento "C" do AMRJ secciona longitudinalmente áreas da região metropolitana que permanecem desprovidas de urbanização (não possuem adequada rede de abastecimento de água, esgotamento sanitário, energia elétrica, etc.), cortando rios, passando próximo a áreas de preservação ambiental e também dentro da Floresta Nacional Mario Xavier, que é uma área endêmica de espécies ameaçadas de extinção. Esse cenário conflituoso entre crescimento industrial e impactos socioambientais negativos foi as motivação inicial dessa dissertação, que abrange também outros temas relacionados com o estudo da rodovia em questão. 
Esta dissertação está dividida em cinco capítulos. No primeiro capítulo, apresentaremos as bases teórico-conceituais que envolvem a aplicação de uma ideologia no planejamento urbano e regional brasileiro. Ademais, faremos uma contextualização histórico-política, nos aproximando do debate sobre o neodesenvolvimentismo e seus impactos socioambientais.

No segundo capítulo será apresentado o estudo de caso da presente dissertação. Ele contém uma breve descrição da conjuntura político-econômica em que esse empreendimento foi lançado e informações básicas sobre o projeto do Arco Metropolitano do Rio de Janeiro (AMRJ). Além disso, traz apontamentos sobre o contexto institucional, com base na análise dos planos diretores e leis orgânicas vigentes nos municípios cortados pelo Arco, em contraponto com o Plano Diretor do Arco Metropolitano (PDAM) e o Relatório de Impacto Ambiental (RIMA).

Posteriormente, analisaremos as justificativas de implantação do Arco e as contradições nelas existentes. 0 terceiro capítulo foca nos aspectos socioeconômicos e na estruturação do território. Assim, nele iremos abordar as quatro grande justificativas para a construção do Arco: a conexão do COMPERJ com o porto de Itaguaí; a geração de emprego; a expansão da mancha urbana e a melhoria da mobilidade na Região Metropolitana do Rio de Janeiro.

Já o quarto capítulo foca nos rebatimentos da construção do Arco e na expansão urbana por ele promovida. Portanto, nele abordaremos a problemática da infraestrutura básica, da habitação e dos impactos socioambientais.

Por fim, teceremos algumas considerações sobre o que foi descrito nos capítulos anteriores, apontando possíveis desdobramentos da presente pesquisa. 
Capítulo 1 


\section{Capítulo 1 \\ Ideologia, Neodesenvolvimentismo e os seus Impactos Socioambientais}

O presente capítulo consiste em uma introdução sobre as bases teórico-conceituais e político-econômicas que serão utilizadas para a análise do AMRJ nos próximos capítulos desta dissertação de mestrado. Ele está dividido em quatro tópicos. 0 primeiro trata dos conceitos de mito e ideologia, aplicados no planejamento urbano e regional.

0 segundo faz um apanhado histórico-político que inclui o desenvolvimentismo no Brasil no seu contexto internacional e a transição para a época neoliberal com os respectivos rebatimentos nas questões socioambientais.

No terceiro tópico, falaremos sobre o século atual com foco no período chamado de "neodesenvolvimentismo" (BRESSER-PEREIRA, 2012), abordando as suas diferenças com relação aos dois períodos anteriores e alguns aspectos do debate político-econômico relacionado às medidas governamentais desse período.

No último tópico entraremos no debate mais relevante desse capítulo para a posterior análise do nosso estudo de caso, os aspectos ideológicos do Neodesenvolvimentismo. Nele, usaremos também as críticas feitas ao desenvolvimentismo que continuam sendo aplicáveis ao Neodesenvolvimentismo, pois permanecem pertinentes quando transpostas para a conjuntura atual.

Visando apenas a uma melhor organização de ideias, subdividimos esse último tópico em três subtópicos para expor de forma clara o debate sobre o uso de ideologias no Neodesenvolvimentismo. 0 primeiro corresponde ao contexto no Capitalismo Internacional; o segundo entra na questões sobre as classes beneficiadas e as prejudicadas por essa visão político-econômica; por último, mas não menos importante, o terceiro foca nos debates mais voltados para as questões socioambientais. 


\subsection{Mito, ldeologia e Planejamento Urbano}

A origem da palavra mito vem do grego antigo, mythos, que por sua vez deriva de dois verbos: mytheyo (contar, narrar, falar alguma coisa para outros) e mytheo (conversar, contar, anunciar, nomear, designar). Assim, na história grega, um mito era uma narrativa de caráter simbólico-imagético que propõe explicar um determinado tema do qual pouco (ou nada) se sabia, como, por exemplo: "de onde vem os seres humanos" (CHAUl, 2000).

Chaui (2000) explica que antes de a filosofia surgir, cabia à religião, às tradições e aos mitos a explicação de todas as coisas sobre as quais pouco se sabia. A autora contrapõe a mitologia à filosofia, mostrando que enquanto a mitologia admite contradições, fabulação e coisas incompreensíveis, a filosofia, ao contrário, formula explicações baseadas necessariamente na coerência, na lógica e na racionalidade.

Por conseguinte, para ter respaldo, os contos míticos eram proferidos por figuras de autoridade, as quais não se contestava. Os ouvintes admitiam a informação como verdadeira, porque confiavam plenamente naquele que a narrava. Em geral, era uma narrativa feita em público, realizada por uma pessoa escolhida pelos deuses, cuja autoridade vem do fato de ter testemunhado diretamente o que está narrando ou por ter recebido a narrativa de quem testemunhou os acontecimentos relatados. Há, assim, um respaldo imaterial e subjetivo, que convence o ouvinte, tendo como base apenas a fé deste. lsso fazia do mito uma história indiscutível e irrefutável, embora fosse desprovido de razão.

Quem narra o mito? O poeta-rapsodo. Quem é ele? Por que tem autoridade? Acredita-se que o poeta é um escolhido dos deuses, que lhe mostram os acontecimentos passados e permitem que ele veja a origem de todos os seres e de todas as coisas para que possa transmiti-la aos ouvintes. Sua palavra - o mito é sagrada porque vem de uma revelação divina. 0 mito é, pois, incontestável e inquestionável (CHAUl, 2000, p.32).

Furtado (1974), em seu livro "0 Mito do Desenvolvimento Econômico", traz o conceito de mito para a época atual e define que os mitos se formam por um conjunto de hipóteses que não podem ser testadas. Sua função principal é, num plano intuitivo, orientar, nortear um processo social ou um trabalho analítico, dando sentido a estes, de modo que os mitos são ideias que exercem influência sobre o pensamento dos seres humanos que se empenham em compreender a realidade social na qual vivem ${ }^{1}$. 0 autor compara um mito a

\footnotetext{
${ }^{1}$ Exemplos disso são o mito do bonsauvage de Rousseau, a ideia do desaparecimento do Estado de Marx ou o "princípio populacional" de Malthus.
} 
um farol na escuridão, que pode iluminar o campo de percepção de um cientista social. Logo, tal farol permite ter uma visão clara de certos problemas e concomitantemente obscurece e até inviabiliza a visão de outras questões.

Desta forma, Furtado adverte que um trabalho analítico pode usar um mito como Norte, como a visão pré-analítica ${ }^{2}$, indispensável para guiar e dar sentido ao ato da análise. Contudo, posteriormente, o pesquisador precisa se aproximar da realidade, dissecando-a com base na racionalidade para que sua pesquisa não seja apenas um reflexo da realidade objetiva. Fazendo uma análise de Furtado (1974), Cavalcanti (2003) afirma que um mito resulta de uma criação coletiva em que a sociedade, não conscientemente, dá forma a um plano de ação. Assim, um mito é também histórico, temporal, e não é desafiado pelos seus contemporâneos. Para este autor, o mito se apresenta como um estereótipo, que determina comportamentos a todo momento, se firmando por meio de costumes e hábitos. Como uma crença compartilhada, a ação ou argumentação baseada em um mito dispensa reflexões, independe de ponderação.

No presente estudo, usaremos o conceito de mito sempre relacionado ao conceito de ideologia conforme colocado por Marx e Engels (1989) no livro "A ideologia Alemã". Para isso, é preciso esclarecer que a origem do termo ideologia está atrelada a uma corrente do pensamento francês da qual fazia parte o filósofo Destutt de Tracy, ${ }^{3}$ que entendia a ideologia como uma ciência que estuda a formação das ideias como fenômenos naturais que exprimem a relação do ser humano com o seu entorno. (CHAUÍ, 1980)

Inicialmente esses filósofos franceses antimonárquicos apoiaram o começo da ditadura napoleônica na França. Porém, as discordâncias sobre a criação da Universidade Francesa levaram Napoleão Bonaparte a, em 1812, usar pejorativamente o termo, declarando que a ideologia queria "fundar sobre suas bases a legislação dos povos, em vez de adaptar as leis ao conhecimento do coração humano e às lições da história" (CHAUí, 1980, p.24-25). Logo, podemos dizer que o sentido Napoleônico do termo percebe a ideologia como um conjunto de ideias que pretende se firmar como lei de uma sociedade sem nem ao menos levar em consideração o seu povo. É, assim, um apanhado de ideias de alguns cidadãos que visam legislar sobre a vida de todos os demais, camuflando essas ideias que lhes beneficiam como sendo comuns a todos e aplicáveis por meio dos aparelhos do Estado.

\footnotetext{
${ }^{2}$ conforme colocado por Schumpeter in Furtado (1974).

${ }^{3}$ no livro "Elementos da ldeologia", publicado em 1801 in Chaui (1980).
} 
Marx e Engels (1989) se apropriaram desse sentido napoleônico do termo para fazer uma crítica aos ideólogos alemães. No livro "A ideologia Alemã", os autores fazem uma análise histórica da divisão social do trabalho e da desigualdade entre as classes sociais, concluindo que não é o Estado que cria a sociedade civil e sim a classe dominante da sociedade civil que dita e molda o Estado. Eles mostraram que independentemente da época, o Estado sempre foi um representante da sua classe dominante, aquela que dispõe dos meios de produção material e também dos meios de produção intelectual. Entretanto, para evitar que as classes dominadas se revoltem, este conjunto 'Estado - classe dominante' precisa manter-se aparentemente como o defensor do interesse coletivo, dando aos seus pensamentos a forma de universalidade, apresentando-os como sendo os únicos razoáveis, os únicos universalmente válidos (MARX E ENGELS, 1989).

Assim, através da ideologia, as normas e leis do Estado que favorecem a classe dominante se apresentam como legítimas, verdadeiras, justas, benéficas e válidas para todos. A função do discurso ideológico assumido pelo Estado tem como objetivo impedir que as classes dominadas fiquem indignadas e se insurjam contra a sua situação de dominação, ao passo que essa realidade é substituída por uma ideia de interesse geral protagonizado pelo Estado (CHAUÍ, 1980).

Em seu livro "Aparelhos ldeológicos do Estado", escrito em 1970, Louis Althusser, tendo como base Marx e Engels (1989), afirma que o discurso ideológico das classes dominantes é propagado através das instituições de Estado, que ele classifica como os Aparelhos ldeológicos do Estado (AIE). Estes AlE podem ser subdivididos em AlE religioso, escolar, familiar, jurídico, político, sindical, cultural e AIE de informação. É possível considerar o Planejamento Urbano e Regional como integrante do AIE jurídico, uma vez que ele pode ter caráter de lei e/ou orientar normas governamentais.

Também baseado na concepção crítica de ideologia colocada por Marx e Engels (1989), Thompson (1993) estuda as maneiras nas quais a ideologia assume diversos tipos de formas simbólicas, servindo para estabelecer e sustentar relações de dominação. Já Chaui (1980), nota que a ideologia pode se apresentar como um conjunto lógico, sistemático e coerente de normas ou regras que indicam e prescrevem aos membros da sociedade o que eles devem fazer e como devem fazer. Este corpo explicativo e prático (normas, regras, preceitos) tem como função dar uma explicação racional para as diferenças sociais, políticas e culturais, sem jamais atribuir tais diferenças à divisão da sociedade em classes. 
Nos capítulos a seguir, usaremos os conceitos de mito e de ideologia aplicados ao planejamento urbano e regional, mais especificamente ao seu discurso escrito: os planos urbanísticos e regionais. Afinal, eles são a expressão textual da ideologia pela via do Estado. O urbanista Flávio Villaça (2001) lembra que instrumentos de planejamento urbano que usam discursos ideológicos têm como função básica facilitar a dominação, tornando-a mais palatável e viabilizando a aceitação por parte dos dominados ao ocultar o real processo social.

Villaça (1999) expõe que há algumas décadas as classes dominantes no Brasil desenvolvem interpretações sobre as origens dos problemas sociais que marcam as nossas cidades, sobretudo nas questões de habitação, transportes, saneamento e meio ambiente. Muitos desses pensamentos se concretizaram em forma de Planos Diretores, que foram vendidos para a sociedade como forma de solução desses problemas. Contudo, o autor ressalta que essas ideias visam na verdade usar o Estado para ocultar as verdadeiras origens daqueles problemas, dado que faltam, às classes que comandam o Estado, capacidade para resolver os problemas e o interesse em fazê-lo.

0 espaço, como disse Lefebvre, tem sido um campo fundamental para a sobrevivência do capitalismo (SOJA, 1980, p.214). Assim sendo, não é surpresa que uma categoria excepcionalmente importante de espaço - o urbano - seja privilegiada na produção de ideologias. "Space is political and ideological. It is a product literally filled with ideologies" (SOJA, 1980, p.210). Isso é o que vem ocorrendo há muitas décadas no Brasil (e provavelmente em toda a América Latina), durante as quais o planejamento urbano tem sido usado como ideologia, inclusive através de contínuas transformações de sua aparência (nomes, formas, conteúdos) (VILLAÇA, 1999 ,p. 185).

Assim, divisão de classes tem seu rebatimento no espaço urbano, sendo as cidades, ao mesmo tempo: resultantes inacabadas das intervenções realizadas ao longo do tempo (pois estão sempre em transformação) e reflexo da sociedade no espaço e local de reprodução dos meios de produção, como indústrias e seus desdobramentos. Enquanto as classes dominantes ditam as transformações "oficiais" das cidades, as classes dominadas implementam as transformações "extraoficiais". Devido ao baixo poder aquisitivo, às classes dominadas não resta outra opção senão habitar em locais periféricos, cujo valor do solo urbano é baixo justamente devido ao difícil acesso e à falta de infraestrutura. Percebemos então que, embora apresente uma aparente desordem, a produção do espaço urbano ocorre de forma coerente, seguindo a ordem do modo de produção dominante (REZENDE, 1982).

Desta forma, o Estado combate essa paradoxal "desordem" com a elaboração de planos urbanísticos que têm como principais objetivos a apropriação do espaço urbano de 
forma organizada e produtiva (sendo desenvolvidos planos e políticas para resolver a crise urbana), minimizar os conflitos e disciplinar o aparente caos. Nesta conjuntura, alguns planejadores tentam, por vezes, levantar e resolver problemas que transcendem a questão propriamente urbana. (REZENDE, 1982; VILLAÇA, 1999).

A história do planejamento urbano brasileiro foi marcada pela presença de um discurso ideológico comum a planos urbanísticos desde a década de 1960 (VILLAÇA, 1999). Em muitos casos, os planos não foram concretizados por ações sólidas do Estado, pelo contrário, eram usados como mecanismos que auxiliavam a ocultar os interesses políticoeconômicos das classes dominantes e a manipular o entendimento das ações que seriam de fato executadas pelo poder público. Por isso, Villaça (1999) ressalta que a intenção de dominação e poder era comumente escondida detrás da fachada do planejamento urbano. Desta forma, planos urbanísticos representaram um instrumento de controle do pensamento, de aceitação e credibilidade das ações impostas por estas classes dominantes. Estando assim, ainda bem próximos das ideologias às quais Napoleão chamou a atenção em 1812 e validavam o pensamento de Marx e Engels sobre a relação de subordinação do Estado às classes dominantes.

Os primeiros planos de intervenções urbanas no Brasil ocorreram nos finais do século XIX e início do XX, tendo como principal objetivo o embelezamento urbano. Nesta fase embrionária, o planejamento não adotava discursos ideológicos e realmente representava instrumentos que visavam organizar as futuras obras públicas. Diferente do que vemos hoje, elas eram efetivamente executadas conforme o planejado. Os planos eram discutidos buscando construir acordos sobre o que e como fazer. Porém, isso só foi possível em decorrência do fato de que apenas os integrantes da classe dominante podiam opinar sobre eles. Sendo um acordo entre iguais, não havia conflitos estruturais e interesses antagônicos na sua essência (VILLAÇA, 1999).

Com o passar do tempo, a sociedade e os seus instrumentos de planejamento urbano e regional foram se transformando. No início do século $X X$, temos a concessão do direito ao voto estendido para as mulheres ${ }^{4}$ e também o surgimento da classe operária no Rio de Janeiro e em São Paulo e, com elas, a consciência popular associada ao seu espaço urbano. Nesta mesma época, surge também uma burguesia urbano-industrial que se alia às camadas populares reunindo forças para derrubar a aristocracia agrícola. Com o declínio da

\footnotetext{
${ }^{4}$ Em 1932 foi instituído o Código Eleitoral Brasileiro, que prevê pela primeira vez o voto das mulheres. 0 sufrágio universal no Brasil é determinado somente na Constituição de 1988, na qual o Brasil finalmente reconhece o direito de voto aos analfabetos, estendendo-o também aos jovens a partir de 16 anos.
} 
hegemonia das classes dominantes no âmbito urbano, os planos passam a não mais publicizar as obras que seriam implantadas, para não criar revoltas populares. 0 medo de revoltas se dava pelo fato de que as obras continuavam não tendo comprometimento com os interesses da classe trabalhadora, beneficiando apenas as elites, pois a classe dominante não tinha propostas e nem interesse em resolver os problemas que se agravavam. Assim, os planos tornam-se apenas discursos nada aliados à prática, afinal não era vantajoso tornar público que seriam feitas apenas as obras que não eram de interesse popular (VILLAÇA, 1999).

Ao longo da primeira metade do século XX, a burguesia urbano-industrial foi assumindo, cada vez mais, o controle da sociedade brasileira e o planejamento urbano também mudou de forma. As décadas de 1960 e 1970 foram marcadas pelo caráter cientificista dos planos urbanos, nos quais imperava a visão de que a única maneira de solucionar os problemas das cidades se dava mediante um forte amparo técnico e científico (VILLAÇA, 1999).

Uma característica recorrente nestes planos foi a realização de extensos diagnósticos. Publicado em 1965, o plano diretor elaborado pelo urbanista grego Constantino Doxiadis para o Rio de Janeiro (também conhecido como Plano Policromático) é um clássico exemplo de tecnicismo da época. Sem nenhuma intenção de ampliar o debate sobre o planejamento da cidade, o plano foi divulgado em inglês e continha um diagnóstico que se estendia longamente por quase quinhentas páginas, das quais apenas nove eram sobre implementações (implementations) e, uma única página foi dedicada a recomendações (recommendations) (VILLAÇA, 1999). Nesse cenário de sucessivos planos que nunca solucionam os problemas urbanos, Villaça pergunta:

Diante dessa situação, algumas perguntas são inevitáveis. Como entender a sobrevivência da ideia de plano diretor como algo importante e consequente apesar de seus sucessivos fracassos? Como entender o prestígio dessa ideia e o fervor com que a ela aderem nossas elites intelectuais, a imprensa e a opinião dominante, quando na verdade ela devia estar desmoralizada? (VILLAÇA, 1999, p. 224).

Para este autor a resposta está na capacidade das classes dominantes de inventar novos discursos ideológicos. Os planos acompanham esses novos argumentos, ganham nova roupagem e uma nova enxurrada de verbetes aparecem: Planos Integrados, Planos Programáticos, Planos Setoriais, Planos Estratégicos, etc., etc.. Todos eles se apresentam como inovadores, como se tivessem o poder de, enfim, solucionar os velhos e os novos problemas. 
No entanto, há que se admitir que, ao longo das ultimas décadas, a classe dominada logrou alguns avanços no campo das políticas urbanas. Dentre elas estão: a moradia como direito constitucional; a função social da propriedade também marcada na Constituição de 1988; a criação do Ministério das Cidades e a criação do Estatuto da Cidade, que estabelece instrumentos e regras para que uma reforma urbana possa, ao menos, ser iniciada. Todos esses avanços, entretanto, estão subordinados aos Planos Diretores Municipais, o que pode ser um limitador da ação dos instrumentos criados na instância federal. Sem a iniciativa dos gestores municipais não há como fazer transformações reais no espaço urbano.

De acordo com Villaça (1999), na história do planejamento urbano brasileiro, a década de 1990 representa o fim de um período. Várias cidades brasileiras voltaram a elaborar planos diretores no início dos anos 1990 e, devido ao avanço da consciência e das organizações populares da década anterior, se inicia um processo de politização. Com o apoio e estímulo do Governo Federal, através do Ministério das Cidades, aconteceram experiências significativas de elaboração de Planos Diretores Participativos no Brasil. Segundo Santos Jr. e Montandon (2011), a publicação da Rede de Avaliação e Capacitação para Implementação dos Planos Diretores Participativos mostra que ainda há inúmeras dificuldades a serem superadas, mas também aponta os benefícios de mecanismos de gestão democrática já criados, como conselhos e instâncias nos quais a participação social influencia no planejamento urbano.

$\mathrm{Na}$ contramão desses avanços, ainda é comum a elaboração de instrumentos de planejamento sem nenhum tipo de participação popular. E, pior, em pouco tempo, esse conceito passa a ser ideologicamente apropriado por planos quase nada participativos, que cumprem superficialmente uma "cota mínima" de participatividade, realizando algumas poucas audiências públicas cheias de apresentações das decisões já tomadas pelos dirigentes municipais e vazias de debates com a população.

Além disso, cabe lembrar que Maricato (2002) expõe que há no Brasil as "leis que pegam" e as "leis que não pegam". Em geral, as primeiras favorecem aos grupos dominantes, enquanto as que caem no esquecimento favorecem aos grupos mais pobres da nossa sociedade. Para a autora, não é por falta de planos que as cidades brasileiras crescem de modo predatório. Os instrumentos de planejamento urbanístico também passam pela lógica da aplicação discriminatória da lei. Assim, ainda que um plano diretor seja montado para atender aos distintos setores da sociedade, ele pode ser parcialmente concretizado, executando apenas as medidas que favorecem as camadas mais altas da sociedade, vez que 
”a aplicação da lei é instrumento de poder arbitrário" (MARICATO, 2002, p.148). Nesse sentido, a autora lembra que a aparente ineficácia de algumas leis ou a inviabilização de algumas medidas pode, na verdade, ser bastante eficaz para favorecer pequenos interesses corporativos.

A leitura das justificativas de planos ou projetos de leis urbanísticas, no Brasil, mostra o quão pode ser ridículo o rol de boas intenções que as acompanham. Ridículo sim, porém não inocente. Cumprem o papel do planodiscurso. Destacam alguns aspectos para ocultar outros. É de conhecimento geral que no Brasil há "leis que pegam" e "leis que não pegam". Tudo depende das circunstâncias e dos interesses envolvidos. É mais freqüente parte do plano ser cumprida ou então ele ser aplicado apenas a parte da cidade. Sua aplicação segue a lógica da cidadania restrita a alguns. (MARICATO, 2002, p.148)

Ferreira (2007) lembra que esse fenômeno do planejamento urbano e regional ocorre pelo caráter patrimonialista do Estado brasileiro. Usaremos aqui o conceito weberiano de patrimonialismo do Estado para descrever a falta de distinção, por parte de alguns governantes, entre as esferas pública e privada, verificando-se, assim, a aliança da burguesia com o Estado burocrático. Segundo Faoro (1975), o patrimonialismo é um domínio institucionalizado, uma forma de poder no qual a comunidade política conduz, comanda, supervisiona os negócios, em primeira instância, como negócios privados seus para, só depois, gradualmente, tratar-los como negócios públicos. Na sua pesquisa, Faoro (1975) conta que, desde da época do Brasil Colônia, nosso Estado reproduz o patrimonialismo culturalmente herdado de Portugal.

0 autor mostra que o patrimonialismo estatal brasileiro sempre esteve ligado ao setor econômico. Da lavoura colonial de exportação à industrialização do século XX, mudase as categorias econômicas mas não a questão social em relação às camadas exploradas. Os recursos ideológicos se diversificam, tomam novas formas, mas seguem compatíveis com o patronato político, em uma "modernização conservadora".

0 poder - a soberania nominalmente popular - tem donos, que não emanam da nação, da sociedade, da plebe ignara e pobre. 0 chefe não e um delegado, mas um gestor de negócios, gestor de negócios e não mandatário. 0 Estado, pela cooptação sempre que possivel, pela violência se necessário, resiste a todos os assaltos, reduzido, nos seus conflitos, à conquista dos membros graduados de seu estado-maior. E o povo, palavra e não realidade dos contestatários, que quer ele? (...) A lei, retórica e elegante, não o interessa. A eleição, mesmo formalmente livre, lhe reserva a escolha entre opções que ele não formulou. (Faoro, 1975,p.882).

Analisando a cidade de São Paulo no século XXl, Ferreira (2007) afirma que, apesar de muito se falar da influencia da "globalização" nos dias atuais, as dinâmicas de produção 
das cidades ainda obedecem, preponderantemente, as relações arcaicas e patrimonialistas. Isso ocorre, dado que "a imiscuição entre Estado e iniciativa privada permite significativos ganhos capitalistas e influencia a produção do espaço da cidade em torno das 'centralidades terciárias" (FERREIRA, 2007, p.222). Assim, temos o que este autor chama de "arcaica cidade-global”, caracterizada pela atual subordinação do desenvolvimento urbano à lógica do capital, sob o histórico patrocínio do Estado patrimonialista.

\subsection{Do desenvolvimentismo ao neoliberalismo}

Como vimos, ao longo da história brasileira, o planejamento urbano se pautou sobretudo pela conjuntura político-social de escala nacional e local. Afinal, se ampliarmos o nosso horizonte de análise, veremos que o microcosmo das cidades é intrínseco ao entendimento da estruturação da sociedade a da situação macropolítica (interna e externa) de um país. Paralelamente à questão do planejamento (como disciplina), iremos aqui introduzir os aspectos histórico-econômicos que nos levam ao debate sobre o Neodesenvolvimentismo. Todavia, antes de entrarmos na questão do discurso ideológico presente no planejamento urbano de políticas neodesenvolvimentistas, abordaremos, sucintamente, o início do processo de industrialização no Brasil para contextualizar os processos político-econômicos dos dias atuais.

De acordo com Furtado (1974), o aumento da renda de uma comunidade (de forma geral, sem considerarmos a distribuição desta renda entre os habitantes) pode decorrer de, no mínimo, três processos diferentes. 0 primeiro seria o desenvolvimento econômico daquele local (que pode concentrar ou distribuir a renda acumulada), o segundo é a simples exploração de recursos naturais não renováveis e o terceiro diz respeito à realocação de recursos objetivando uma especialização em um sistema de divisão internacional do trabalho.

Furtado (1974) explica que na maioria dos países conhecidos como subdesenvolvidos na década de 1970, o processo de modernização e diversificação do consumo, com a introdução de novos padrões de consumo, ocorreu baseado na elevação da renda. Nestes países, a elevação de renda, em geral concentrada em poucas camadas da população, foi gerada pelo segundo e pelo terceiro tipo de processos acima mencionados. Na história da 
economia brasileira, por muito tempo, o motor da geração de renda foi a alocação de recursos visando o comércio exterior, sobretudo com a extração vegetal e mineral. Nesse contexto, o autor frisa que, na mudança da agricultura tradicional para a moderna, a concentração da propriedade territorial no Brasil foi fator fundamental para que os aumentos de produtividade beneficiassem apenas uma pequena parcela da população. E foi essa minoria rica e modernizada a propulsora do desenvolvimento urbano e do começo da industrialização.

Entre os anos de 1894 e 1930, época em que, como já mencionamos aqui, o planejamento urbano era feito por um acordo entre dirigentes de um mesma classe social, a economia brasileira dependia quase que exclusivamente da agricultura e da pecuária. No plano político do Brasil, estava estabelecida a chamada "política do café com leite”, em que a oligarquia paulista cafeeira se revezava no poder com a oligarquia pecuarista mineira, escolhendo em mandatos alternados o presidente da República.

Enquanto isso, após o fim da primeira guerra mundial (1918), os Estados Unidos da América (EUA) viviam o seu "boom" industrial. A indústria americana cresceu muito, no entanto, o poder aquisitivo da população não acompanhou esse crescimento. Em 1929 veio a crise gerada por várias razões, entre elas pelo fato de que a superprodução agrícola e o aumento da produção industrial colapsaram com a diminuição das exportações para a Europa e com a não capacidade de absorção pelos consumidores internos de todo o excedente. Toda essa instabilidade acarretou na desvalorização das ações de muitas empresas americanas e consequentemente na quebra da bolsa de Nova lorque.

Nessa época, o Brasil era fortemente dependente das exportações de café e tinha uma enorme dívida externa, que precisava ser financiada com a venda desse produto. Por ter os EUA como o seu principal mercado consumidor de café, o Brasil foi intensamente afetado pela crise americana. Com uma enorme produção e sem comprador, a saca do café no mercado internacional caiu quase $90 \%$ em um ano. Nesse cenário, sobe ao poder Getúlio Vargas. Na tentativa de controlar o valor do café, o governo federal comprou grande parte dos estoques dos produtores e queimou milhões de sacas no porto de Santos. A partir daí, na Era Vargas (1930-1945) o Brasil começa a transformar a sua economia e se intensificam os investimentos na industrialização nacional. 


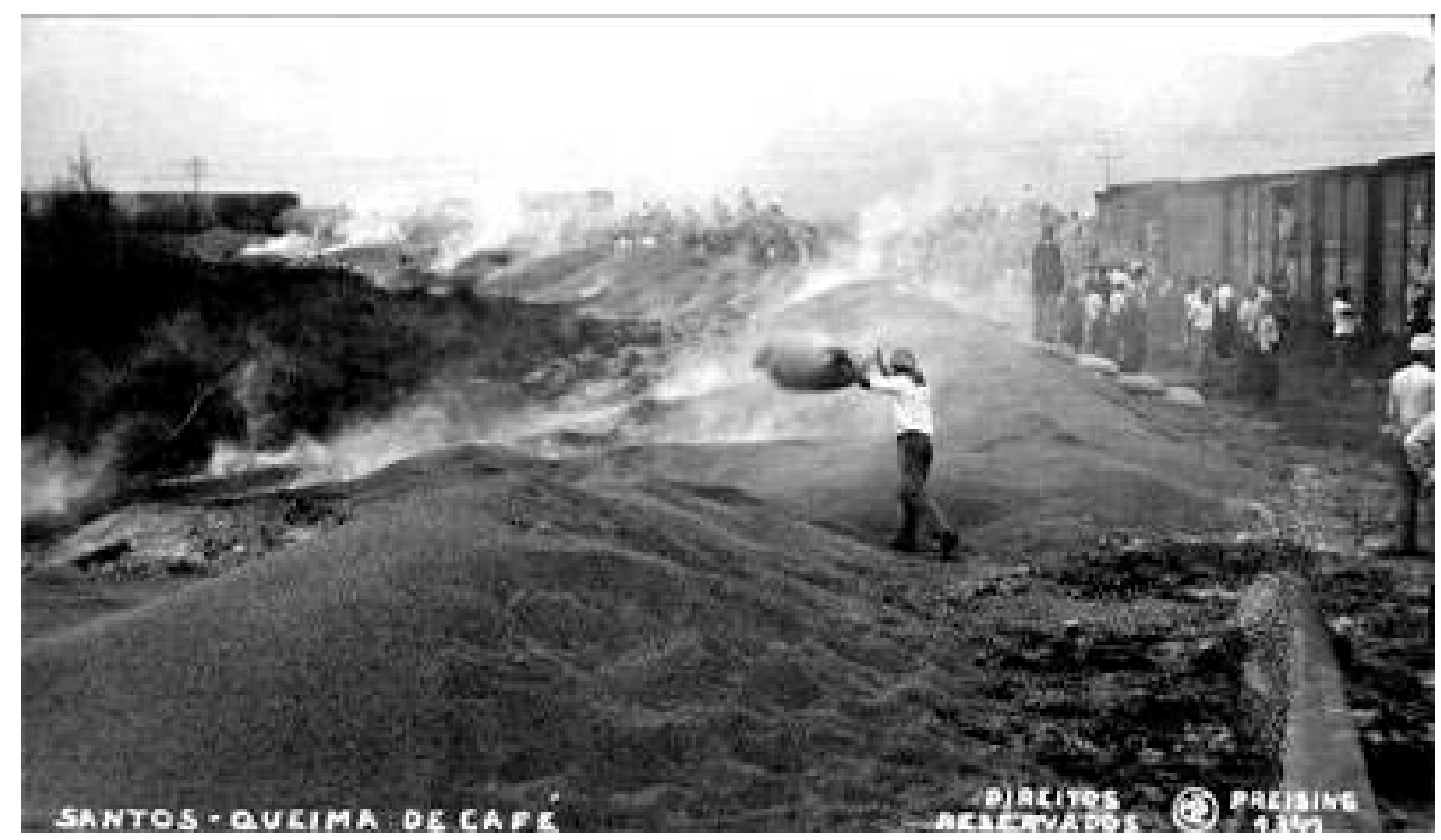

Figura 1 - Queima de café em Santos, patrocinada pelo governo Vargas, nos anos 1930. Foto de Theodor Preising.

É devido a esse cenário de crise do sistema de produção vigente que o processo de industrialização torna-se o eixo norteador das discussões e medidas políticas. Em decorrência, na Era Vargas (1930-1945) ocorrem as primeiras grandes medidas para o desenvolvimento industrial brasileiro, como a construção da Usina de Volta Redonda, no Rio de Janeiro em 1941, e a fundação da Companhia Vale do Rio Doce, em 1942. Paralelamente, Vargas também criou as leis trabalhistas fundamentais para a organização da sociedade nessa fase de crescimento econômico-industrial.

Após o primeiro mandato de Vargas, o cenário mundial já está reorganizado. Entre 1944 e 1945 são criados o Banco Mundial, o Fundo Monetário Internacional (FMI) e a Organização das Nações Unidas (ONU). Conforme colocado por Ferreira (2012), é importante frisar que a história do desenvolvimentismo no Brasil e na América Latina sempre foi marcada, fundamentalmente, pela relação Norte-Sul, em situação de dependência e são sempre assinaladas pela marca dos interesses a ele associado. Porém, a relação de submissão aos interesses estrangeiros e a hegemonia regular desses interesses nas decisões internas só foram possíveis porque, internamente, havia uma elite oligárquica que fez essa opção política.

De que desenvolvimento estamos falando? Este termo, na análise da história da AL, deve estar sempre acompanhado de fórmulas "para que finalidade?" e "para quem?". A dominação Norte-Sul é tão marcante na história do continente, que as opções de "desenvolvimento" também são sempre assinaladas pela marca 
dos interesses a ele associado. "Desenvolvimento" para que finalidade? e para beneficiar quem? (tradução livre de Ticianne R. de Souza) ${ }^{5}$ (FERREIRA, 2012, p.2).

É nessa lógica que a ONU cria, em 1948, o seu braço regional na América Latina, a Comissão Econômica para a América Latina e Caribe (CEPAL), com o objetivo de incentivar a cooperação econômica entre os seus membros. Contando com a participação de grandes economistas como Raul Prebisch e Celso Furtado, a CEPAL, desenvolveu estratégias políticas para os chamados "países subdesenvolvidos" superarem a pobreza. Tais estratégias focavam em reduzir a diferença econômica entre eles e os países ricos através do crescimento industrial nacional e, consecutivamente, da substituição de importações. Logo, o pensamento Cepalino foi uma resposta às teorias liberais em voga na América Latina e no Brasil durante os anos 1930 e 1940.

Efetuando uma crítica à essa doutrina dominante, a CEPAL salientava que a industrialização e a incorporação do progresso técnico eram as únicas saídas que os países latinoamericanos dispunham para elevar paulatinamente a qualidade de vida da população. Deste modo, a CEPAL influenciou a implantação de um modelo econômico calcado no keynesianismo ${ }^{6}$, auxiliando o Estado brasileiro no seu processo de industrialização pesada. Ferreira (2012) lembra que as mudanças políticas internas ocorridas durante os primeiros anos do século XX aumentaram as pressões internas por mudança, com o apoio das novas gerações altamente empreendedoras e da elite local burguesa.

Nesse contexto, Getúlio Vargas volta ao poder para o seu segundo mandato (19511954) e começa a implementar o desenvolvimentismo nacionalista ${ }^{7}$, tendo como marcos a criação do Banco Nacional de Desenvolvimento Econômico (BNDE) ${ }^{8}$, em 1952, e a célebre frase ”0 petróleo é nosso!", conhecida por ter sido exclamada por Getúlio na ocasião da descoberta de reservas de petróleo na Bahia que culminaram na criação da Petrobras em

\footnotetext{
${ }^{5}$ Texto original em francês: "De quel développement parlons nous ? ce terme devrait, dans l'analyse de l'histoire de l'AL, être toujours accompagné des formules "pour quels objectifs ? " et "pour qui ? ". La domination N/S est si marquée dans l'histoire du continent, que les options de " développement " sont elles aussi toujours marquées par l'empreinte des intérêts qui s'y associent. "Développement " pour quels objectifs ? et pour bénéficier qui ?"

6 Se refere a um teoria econômica, contrária às concepções liberais, consolidada pelo economista John Maynard Keynes, na qual o Estado controla a economia com o objetivo atingir o pleno emprego e é o responsável por promover políticas sociais, também conhecido como "Estado de bem-estar social".

7 Segundo Bresser Pereira, "o nacionalismo é a ideologia fundamental da terceira fase da história da humanidade, a fase industrial, quando os estados nacionais se tornam a forma de organização políticocultural que substitui o império". In BRESSER-PEREIRA (2014).

${ }^{8}$ Cabe lembrar que as preocupações sociais só são incluídas, em tese, na política de atuação do BNDE em 1982, quando passou a se chamar Banco Nacional de Desenvolvimento Econômico e Social (BNDES). Fonte: http://www.bndes.gov.br/SiteBNDES/bndes/bndes_pt/lnstitucional/ 0_BNDES/A_Empresa/historia.html último acesso em 11 de dezembro de 2014.
} 
1953. Após a frase tornar-se famosa, historiadores descobriram que ela foi, na verdade, criada por Otacílio Raínho, professor e diretor do Colégio Vasco da Gama, no Rio de Janeiro, um marqueteiro casual. ${ }^{9}$

Anos depois, foi a vez do presidente Juscelino Kubitschek (no poder entre 1956 e 1961) incentivar o crescimento das indústrias com medidas como o seu conhecido "Plano de Metas”, cujo principal objetivo era acelerar o processo de substituição de importações, já iniciado por Vargas. Pertencente à corrente nacional-desenvolvimentista, Juscelino representava aqueles que queriam substituir a elite agrária por uma revolução democráticoburguesa, baseando-se no discurso ideológico de que seria possível superar o subdesenvolvimento brasileiro em apenas cinco anos de mandato.

Tanto Getúlio como Juscelino podem ser classificados como desenvolvimentistas. Contudo, há que se pontuar que a era Vargas foi marcada pela consolidação da industria brasileira de base, que permitia assim a formação de indústrias de bens intermediários e, consequentemente, as de bens de consumo. Já o período de Juscelino foi marcado pela abertura do Brasil para a entrada das multinacionais, que produziam bens de consumo sem a transferência da tecnologia e sem executar a estruturação de toda cadeia industrial brasileira.

Assim, a rapidez dos "50 anos em 5" se dá de forma superficial e em um modelo de dependência, atendendo à pressão das multinacionais que visavam entrar no Brasil por conta da oferta de mão de obra barata. Segundo Oliveira (1972), "a aceleração da inversão a partir do período Kubitschek, fundada numa base capitalística interna pobre e nas condições internacionais descritas, requeria, para sua viabilização, um aumento na taxa de exploração da força de trabalho." Notamos então, que a questão do trabalhador teve tratamento diferente nesses dois períodos. Enquanto Vargas cria leis de proteção e benefícios aos trabalhadores, o modo de industrialização de Kubitschek tem como base a exploração dos mesmos.

Algumas das medidas que de fato saíram do papel, no período de Kubitschek, foi a criação da Usina hidrelétrica de Furnas em 1958 e a implantação de rodovias. Porém, foram realizadas às custas de um alto endividamento público, já que foram financiadas, em grande parte, por investimentos privados nacionais e estrangeiros, interessados em viabilizar a

\footnotetext{
${ }^{9}$ Segundo: MÜLlER, Angélica Müller e DI SÁBATTO, Tatiana. Entrevista com Maria Augusta de Toledo Tibiriçá Miranda. Data da entrevista: 24/05/2005. Editora Relume, p. 5.
} 
instalação de suas indústrias. Paradoxalmente, o dito desejo de cortar a relação de dependência com o comércio exterior gerou uma grande dívida externa.

Com o Regime Militar, o Brasil experimentou o chamado "milagre econômico", com taxas de crescimento do Produto Interno Bruto (PIB) que chegaram a atingir 14\% em 1973 (SISCÚ; PAULA; MICHEL, 2007). Contudo, alguns autores, como Siscú, Paula e Michel, questionam os "milagres" desta época pontuando que a industrialização brasileira foi realizada sem a criação de capacidade própria de inovação e financiamento. 0 "desenvolvimentismo" continuou tendo o Estado como principal planejador, sustentador financeiro e produtor direto de insumos básicos e infraestrutura. A educação básica não foi prioridade e tampouco foi criado um sistema nacional de inovação com interface entre universidades, centros de pesquisa e o setor produtivo. 0 financiamento pode ser considerado o "calcanhar de Aquiles" do processo de industrialização brasileiro, já que, comumente utilizou-se a via do financiamento inflacionário e do endividamento externo.

Siscú, Paula e Michel (2007) se baseiam na história mundial para mostrar que não há capitalismo forte sem um empresariado nacional robusto. Ou seja, quando em um processo de desenvolvimento não se consolida um "núcleo endógeno" constituído de um empresariado nacional forte e competitivo, esse desenvolvimento se torna frágil, já que não são criados grupos empresariais com capacidade para enfrentar a pesada competição internacional de comércio e investimentos.

Já em 1974, Furtado considerava que o subdesenvolvimento tem raízes em condições históricas, em que são concomitantes o processo interno de exploração e o processo externo de dependência. Analisando a sua contemporaneidade, ele conclui que a intensidade do influxo de novos padrões de consumo induz que a renda seja mais concentrada. Portanto, o aumento da dependência externa também demanda o crescimento da taxa interna de exploração. Assim, o autor enfatiza que, nesse contexto de forte dependência externa, a alta das taxas de crescimento ao invés de reduzir o subdesenvolvimento na verdade tende a agravá-lo, uma vez que tende a aumentar as desigualdades sociais. Nessa mesma linha, pesquisando o cenário atual, Piketty (2014) segue demonstrando que o crescimento por si só não é capaz de reduzir as desigualdades econômicas de uma nação. Os estudos desse autor mostram que até países com altos indices de crescimento econômico, como os Estados Unidas da América, podem apresentar uma significativa desigualdade de distribuição de renda. 
No que tange às questões ambientais, cabe lembrar que entre 1930 e 1950 foram criados alguns departamentos relacionados ao tema, como o Departamento Nacional de Obras de Saneamento (DNOS), o Departamento Nacional de Obras contra a Seca (DNOCS), o Serviço Especial de Saúde Pública (SESP) e a Fundação Brasileira para a Conservação da Natureza. Contudo, apesar do grande crescimento de uma indústria de base (petróleo, aço, portos e outras infraestruturas), nessa época a preocupação ambiental ainda não era pauta relevante no âmbito nacional.

Apenas em 1962, com o lançamento do livro de Rachel Carson, "Primavera Silenciosa" (Silent Spring) - um best seller, traduzido para 30 idiomas - é que o debate ambiental ganha repercussão. Carson apontava os malefícios do uso excessivo de pesticidas que vinham sendo largamente usados, sobretudo do DDT $^{10}$ (Dicloro-Difenil-Tricloroetano), que contamina alimentos (e consequentemente humanos, tendo sido inclusive detectado no leite materno) aumenta os riscos de câncer, causa alterações genéticas e até a extinção de algumas espécies de animais.

Alguns anos depois, em 1966, é firmado o Pacto Internacional sobre os Direitos Humanos em Assembléia Geral da ONU. Na sequência, em 1968, é fundado o Clube de Roma que, posteriormente, em 1972, publica o Relatório "Os Limites do Crescimento" (The Limits to Growth). Paralelamente, no Brasil, em 1965, surge o Código Florestal e, em 1967, a Lei de Proteção à Fauna, o Código de Pesca e o Código de Mineração. Nos finais da década de 1960, o Brasil participa de convenções e reuniões internacionais relacionadas à ONU nas quais assina acordos, pactos e termos de responsabilidade.

Em 1974, Furtado declara que a referida publicação do Clube de Roma nada agradou aos economistas da época. Eles estavam apenas voltados para os complexos esquemas financeiros e para o impulso dinâmico da acumulação de capital trazido pelo progresso tecnológico e não se preocupavam com o seu contexto e suas consequências sociais, culturais ou ambientais. Observa-se no texto de Furtado (1974) que as tensões entre industrialização e questões socioambientais surgem nessa época já claramente como conflito.

As grandes metrópoles modernas, com seu ar irrespirável, crescente criminalidade, deterioração dos serviços públicos, fuga da juventude na anticultura, surgiram como um pesadelo no sonho de progresso linear em que se embalavam os teóricos do crescimento. Menos atenção ainda se havia dado ao

\footnotetext{
${ }^{10}$ Informações do filme Earth Days, dirigido por Robert Stone e distribuido por Zeitgeist Films in theaters. 2009. Disponível em: < https://www.youtube.com/watch?v=NtZWMHjDX78>, último acesso em dezembro de 2014.
} 
impacto no meio físico de um sistema de decisões cujos objetivos últimos são satisfazer interesses privados. Daí a irritação causada entre muitos economistas pelo estudo The Limits to Growth, preparado por um grupo interdisciplinar, no M.I.T. para o chamado Clube de Roma (FURTADO, 1974, p.16-17).

Em 1977, a Organização das Nações Unidas para a Educação, a Ciência e a Cultura (UNESCO) promoveu a conferência intergovernamental sobre educação ambiental. Quatro anos depois, seguindo uma tendência mundial, o Brasil, através da Secretaria Especial do Meio Ambiente (de 1973), estabelece a Política Nacional do Meio Ambiente, na qual criouse o Sistema Nacional do Meio Ambiente (SISNAMA) e instituiu-se o Cadastro Técnico Federal de Atividades e Instrumentos de Defesa Ambiental. A partir daí começaram a ser criadas unidades de conservação do meio ambiente, entre elas a Floresta Nacional Mario Xavier $^{11}$ que será citada nos próximos capítulos dada a sua relação como o Arco Metropolitano do Rio de Janeiro.

Apesar desses avanços, Bertucci et al. (2002) observam que durante a década de 1970 até o início dos anos 1980, vigorou nas esferas do governo brasileiro o que eles chamam de "conservadorismo dinâmico". Este termo se refere a uma estratégia política na qual inicialmente se aceita o discurso da preservação ambiental. Entretanto, em seguida, a prática real das medidas ambientais é hermeticamente isolada e mantida em uma estrutura burocrática sem poder. Desta forma, não existiam conflitos, pois havia sido construído um bloco estatal único do meio ambiente, que era perfeitamente apropriado ao modelo de desenvolvimento expansivo vigente.

Esses autores fazem uma crítica similar à de Furtado, comentando que o capitalismo fordista vendia uma concepção ideológica de mundo, criando uma cultura urbanoconsumidora que transformava o cidadão em comprador, impondo uma noção de cidadania a ser adquirida através do poder de compra, do consumo, "ameaçando assim transformar nossos sonhos para o futuro num grandioso pesadelo que pode crescer até consumir todo o planeta” (BERTUCCl et al., 2002, p.23). Logo, o crescimento econômico tornou-se a meta central dos governos e das cidades, sendo o Produto Interno Bruto (PIB) visto como o maior indicador do desenvolvimento nacional.

Nesse cenário, em nome do desenvolvimento econômico se tornaram aceitáveis a destruição de grandes parcelas do meio ambiente, além da sobre-exploração dos recursos naturais e do trabalho humano. Além disso, construiu-se um discurso no qual os impasses

\footnotetext{
${ }^{11}$ Criada pelo Decreto no 93.369 de 08 de outubro de 1986.
} 
sociais e ambientais seriam resolvidos com os avanços tecnológicos e econômicos (BERTUCCl et al., 2002).

Ferreira e Ferrara (2012) observam que este modelo desenvolvimentista brasileiro chamado por alguns autores de "Fordismo periférico", ou "modernização conservadora" 12 revelou-se uma forma desregulada de crescimento, baseado em um padrão econômico de extrema concentração das riquezas e, consequentemente, de alto impacto ambiental. Os problemas urbanos, sobretudo no que diz respeito à moradia popular, foram enormemente agravados pelo processo de crescimento demográfico exponencial em decorrência da instalação de novas oportunidades de emprego, aliado à falta de investimentos no setor habitacional e às profundas desigualdades sociais. Dentre os problemas ambientais estão a destruição sistemática da vegetação e os elevados níveis de poluição, incluindo fenômenos como chuvas ácidas decorrentes do modo de produção de certos tipos de indústria.

Esta dupla de autores ainda afirma que ao longo do processo de industrialização, a ausência proposital do Estado foi interessante para manter o baixo custo da mão de obra, beneficiando a taxa de lucro da burguesia e sustentando o crescimento econômico. Não por acaso, nos países subdesenvolvidos a precariedade habitacional tornou-se regra, assumindo a forma de favelas, cortiços, loteamentos irregulares, palafitas, etc. Também passou a ser comum a autoconstrução de habitações por vezes insalubre, em locais impróprios para moradia, de péssimas condições físicas, frágil relação com a malha e as infraestruturas urbanas e distanciamento dos centros de trabalho.

Segundo Bresser-Pereira (2012), a partir dos anos 1980, grande parte dos países passaram pelos trinta anos neoliberais do Capitalismo (1979-2008) ${ }^{13}$, caracterizados pela abertura das fronteiras aos movimentos internacionais de capitais. Ele conta que durante esse período a palavra 'desenvolvimentismo' tornou-se pejorativa, sendo usada como populismo e/ou irresponsabilidade fiscal, fazendo menção às práticas de alguns governantes no final dos anos 1960 e início dos 1970. Para o autor, nessa época de fato se praticou um "populismo em nome de um keynesianismo vulgar e equivocado" ${ }^{14}$ face à crise econômica decorrente do aumento mundial do custo do petróleo, da quebra das principais bolsas de valores brasileiras, da dívida externa contraída nos anos anteriores, entre outros.

\footnotetext{
12 Segundo os autores estes termos foram respectivamente usados por Alain Lipietz, no Norte, e pelos intérpretes da formação brasileira, como Tavares e outros, no Brasil. TAVARES, Maria da Conceição. (Des) ajuste global e modernização conservadora. Rio de Janeiro: Paz e Terra, 1993.

${ }^{13}$ Da posse de Margaret Thatcher como primeira-ministra do Reino Unido à crise econômica global de 2008.

${ }^{14}$ Bresser-Pereira(2012), p. 1.
} 
Ferreira (2007) detalha o cenário econômico mundial do final do século XX lembrando que, se por um lado a informatização elevou a produção a níveis nunca antes vistos, por outro, instaurou-se um processo de substituição da mão de obra humana por máquinas. Assim, o sistema capitalista produzia cada vez mais, empregando cada vez menos. De modo que "a crise do capitalismo contemporâneo é, em essência, a típica crise de superprodução que já assolara o sistema em 1929" (Ferreira, 2007, p.95). 0 diferencial seria que, agora, as inovações na informática e na telemática permitiram uma desconcentração geográfica da produção.

Nesse contexto, inicia-se uma onda neoliberal na América Latina, que tem seu auge no Brasil com os dois governos consecutivos do presidente Fernando Henrique Cardoso. Em 1993, o "Consenso de Washington" determina medidas como: a abertura de seus mercados para investimentos do exterior, a privatização de empresas estatais (as de infra-estruturas) e a abolição de regulamentações que impeçam a aquisição das empresas desses países pelas gigantes transnacionais. Desse modo, esse tipo de relação com o capital internacional "condiciona não só o que vai ser produzido internamente, mas também como (padrões tecnológicos, ambientais, laborais e outros) e para quem (bens de consumo supérfluos, commodities para exportação)” (BERTUCCl et al., 2002, p.45-46, grifos dos autores).

Nesse cenário, Ferreira (2007) aponta que essa expansão internacional é uma "modernização conservadora" e ocorre sob dois aspectos. 0 primeiro é a incorporação dos ricos dos países periféricos no mercado de consumo, favorecendo não só o setor industrial (com o aumento do consumo de celulares, tênis, etc.) como também o setor de serviços e infraestrutura (com a entrada de companhias de telefonia, bancos, seguradoras, etc.).

0 segundo aspecto é o aprimoramento da divisão internacional do trabalho. As novas tecnologias possibilitaram uma "reengenharia" da gestão empresaria, que permitiu essa desagregação espacial do sistema produtivo (FERREIRA, 2007), no qual, em geral, as empresas multinacionais mantém suas sede econômicas nos países centrais e suas indústrias em países periféricos. As empresas buscaram em cada país aquilo que eles poderiam oferecer de vantagem: mão de obra e matéria prima baratas, oferta de isenções fiscais, desregulação ambiental, etc. (BERTUCCl et al., 2002; FERREIRA, 2007).

Bertucci et al. (2002) apontam que nessa época, o equilíbrio econômico era prioridade máxima do governo e o descaso com relação às demais políticas públicas se dava em nome deste. Fiori (1995) frisa essa tortuosa relação entre as taxas da economia e as políticas públicas ao expor que "o esquema rígido da política deflacionária e o risco de 
instabilização especulativa eliminaram as possibilidades de qualquer política pública - a saúde do povo depende da saúde dos bancos" (FlORI, 1995). Bertucci et al. (2002) acrescentam que durante os dois governos de Fernando Henrique Cardoso "a sustentabilidade do meio ambiente dependeu fortemente da sustentabilidade dos bancos" (BERTUCCl et al., 2002, p.50). Para estes autores, com o estreitamento da esfera pública, as questões ambientais também foram influenciadas pela lei de mercado, entrando no ambiente de negócios. Assim, esse "mandato do mercado" foi marcado pelo derrame clandestino de efluentes nos rios e baías, pela exploração predatória das florestas, pela intensificação da exportação de recursos naturais e pela energia barata para o mercado global.

Paralelamente, em âmbito internacional, as questões ambientais ganharam alguma força com a realização da Conferência das Nações Unidas sobre o Meio Ambiente e o Desenvolvimento, que se tornou conhecida como Rio92, ou Eco92. Ainda que nesse encontro tenha sido elaborado um programa de ação conhecido como Agenda 21, na época, poucas medidas de fato foram implantadas no Brasil. Pelo contrário, a degradação ambiental se dava de forma livre, com pouquíssimo controle do Estado, sobretudo pelo acesso relativamente fácil e barato à energia e aos recursos naturais e pelo fato de a produção agrícola e industrial estarem voltadas para o consumo das elites e para a exportação.

Nesse contexto, as melhorias de alguns padrões ambientais de produção e das exportações da década de 1990 tiveram, na verdade, origem nas pressões que os países importadores faziam para que o Brasil seguisse as exigências internacionais dos mercados consumidores externos. Ou seja, como não poderia deixar de ser, em pleno neoliberalismo, as medidas que de fato foram implantadas foram aquelas com origem nas exigências do mercado. Todavia, o mercado interno não foi beneficiado, pois os setores produtivos que estavam voltados para o mercado interno obedeciam a padrões ambientais significativamente menos rigorosos (BERTUCCl et al., 2002)

Apesar da população não ter conseguido as mesmas reivindicações internacionais, Bertucci et al. (2002) frisam que, nessa época, em um primeiro momento pós-ditadura, surgem os movimentos ambientalistas brasileiros. Após o momento do "meio ambiente do Estado" e do "meio ambiente de negócios", os movimentos sociais começaram a desenvolver uma visão mais consolidada de meio ambiente. No entanto, aos poucos, alguns setores organizados da sociedade civil foram sendo neutralizados, diversas Organizações 
Não Governamentais (ONGs) foram sendo cooptadas e se viram induzidas a substituir o seu envolvimento em lutas sociais por atividades de prestação de serviços de consultoria, para empresas que buscavam mitigar ou até legitimar a poluição.

0 'sindicalismo de resultados' reflete, em parte, a substituição de um welfare que nunca existiu em nosso país por um welfare mais incitativo, que reserva a benevolência do estado aos trabalhadores que se submetem aos salários e às condições que lhes impõem as empresas. Um 'ecologismo de resultados', por analogia, também evidencia a disposição de se sacrificar as conquistas obtidas na legislação e nas normas ambientais em troca de apoio a ações fragmentárias e subsidiárias que sancionam a 'poluição legítima' (BERTUCCl et al., 2002, p.52).

\subsection{Neodesenvolvimentismo}

Após o período neoliberal vivido no país no final do século $X X$, alguns autores observam o crescimento do chamado Neodesenvolvimentismo. Usaremos aqui esse termo para tratar da conjuntura política brasileira a partir de 2003 até os dias atuais. Como veremos, algumas correntes teóricas no Brasil, passaram a usar o termo de forma a indicar que, nos últimos anos, houve uma maior preocupação com a industrialização brasileira, fazendo assim alusão ao período desenvolvimentista de meados do século passado.

Segundo Sampaio Junior (2014), o neodesenvolvimentismo é um fenômeno recente e localizado. É uma nova tendência do pensamento econômico, mas circunscreve-se a pequenos círculos acadêmicos, ainda que venha se expandindo e resistindo à prova do tempo.

Sampaio Júnior vê no cenário político atual a configuração de duas grandes forças, a neodesenvolvimentista, que está hoje à frente do governo federal, e a monetarista, que visa a volta do neoliberalismo da década de 1990.

A onda neodesenvolvimentista está diretamente relacionada às intrigas e conspirações palacianas entre as duas facções que disputam o controle da política econômica brasileira: a monetarista - braço direito do neoliberalismo - e a autoproclamada 'desenvolvimentista' - braço esquerdo da ordem. Fenômeno análogo já tinha se esboçado no primeiro governo de Fernando Henrique Cardoso, contrapondo as diretrizes do Banco Central, liderado por Gustavo Franco, às políticas do BNDES, então sob a influência dos irmãos Mendonça de Barros (SAMPAIO JUNIOR, 2012, p.678). 
Ex-ministro da Administração e Reforma do Estado no governo Fernando Henrique Cardoso, mas atualmente um neodesenvolvimentista declarado, Bresser-Pereira (2012) julga que o neodesenvolvimentismo começou a ser identificável no início dos anos 2000 quando havia ainda uma hegemonia total neoliberal e neoclássica. Segundo ele, tanto o neodesenvolvimentismo quanto o neoliberalismo defendem a responsabilidade fiscal. Contudo, os liberais ignoram a nação e defendem o crescimento com poupança externa, ou seja, com déficit em conta corrente e endividamento externo. Além disso, consideram que o mercado regula a taxa de câmbio de forma satisfatória. Já os neodesenvolvimentistas se caracterizariam por: entender o Estado como agente do desenvolvimento; buscar o capital internamente (com a venda de títulos públicos, por exemplo); rejeitar os déficits em conta corrente; observar que na taxa de câmbio há uma tendência à sobreapreciação devido à doença holandesa e às entradas excessivas de capitais e, com isso, recomendar a administração da taxa de câmbio. Assim, na visão deste autor, os neodesenvolvimentista são os mais responsáveis do ponto de vista cambial e são os mais nacionalistas do ponto de vista Econômico.

Siscú, Paula e Michel (2007) concordam que o neodesenvolvimentismo se diferencia do neoliberalismo sobretudo por visar a constituição de um Estado forte capaz de regular a economia e voltado para o financiamento (complementar à ação privada) da atividade produtiva e não para a atividade especulativa. A partir daí, para otimizar a atividade produtiva é necessário fazer o que alguns autores chamam de "reforma da gestão pública". Para esses autores, trata-se de adotar uma forma de gestão que aproxime a relação entre gerentes públicos e privados, mas mantendo no Estado o controle das decisões mais importantes relativas às políticas públicas, sem descentralizá-las (afinal, cabem às esferas governamentais, eleitas democraticamente, as definições que mais impactam a sociedade).

Na visão de Bresser-Pereira (2012), a estratégia novo desenvolvimentista se baseia numa coalizão entre classes formada por empresários dos setores industriais e terciário, pela tecnoburocracia pública, por parte da tecnoburocracia privada e pelos trabalhadores. Já a coalizão neoliberalista (contrária ao desenvolvimento) conta com capitalistas rentistas (interessados em juros elevados e baixa inflação), pelos financistas locais (que recebem comissões dos primeiros para administrar sua riqueza), e pelos interesses estrangeiros, que objetivam ocupar o mercado interno nacional com suas exportações ou a produção de suas empresas multinacionais. Na análise do autor, esta coalizão decorre do complexo de inferioridade em relação ao Norte sentido pelas elites dos países retardatários que ainda 
mantêm um elevado grau de dependência ou de colonialismo. Para ele, a coalizão desenvolvimentista visa distribuir riqueza, já a rentista busca apenas capturar renda, sem necessariamente envolver produção ou trabalho.

A grande questão está no fato de que a coalizão liberalista é composta por classes com interesse mais harmônicos. Já os neodesenvolvimentistas contam com a coalizão de duas classes historicamente conflitantes: empresários e operários. 0 autor reconhece que o desenvolvimentismo demanda uma associação básica bastante contraditória entre a elite e o povo. Contudo, para ele, estas classes vivem "uma relação permanente de amor e ódio, de conflito e cooperação" (BRESSER-PEREIRA, 2012, p.14). Nesse contexto, o autor usa o argumento do interesse coletivo ao falar que, há que se buscar uma cooperação entre os setores da sociedade, visando o crescimento do mercado interno e a garantia de autonomia nacional.

Embora tenha suas origens no "velho desenvolvimentismo", o neodesenvolvimentismo se difere em alguns aspectos referentes ao seu tempo, tendo um olhar crítico para a estratégia levada a cabo em meados do século XX. A realidade atual é mais múltipla, mais complexa e em certo sentido muito mais indecifrável (SISCÚ, PAULA e MICHEL, 2007; BRESSER-PEREIRA, 2012). Além disso, em meados do século XX, o setor privado não tinha capacidade de realizar grandes investimentos na infraestrutura e na indústria de base, e por isso coube ao antigo Estado desenvolvimentista fazê-los. Atualmente, o setor privado tem maior protagonismo, não faz mais sentido a atuação direta do Estado brasileiro em setores como indústria siderúrgica ou petroquímica, pois as disputas comerciais internacionais são muito mais acirradas e complexas. 0 Estado-empresário nos moldes do passado é desnecessário, embora a atuação do Estado continue sendo importante nos setores que são monopólios naturais (SISCÚ, PAULA e MICHEL, 2007; BRESSERPEREIRA, 2012).

A partir desses autores, notamos que o desafio do neodesenvolvimentismo é conciliar alguns dos aspectos "positivos" do neoliberalismo com os aspectos "positivos" do velho desenvolvimentismo. Dentre o primeiro grupo está o comprometimento com a estabilidade da moeda, a austeridade fiscal e a competitividade no mercado internacional. No segundo está a pretensão de conservar o crescimento econômico e de promover o crescimento industrial com mais rapidez, mantendo a autonomia nacional e o papel regulador do Estado. 0 neodesenvolvimentismo ainda objetiva aliar estes posicionamentos com outras 
demandas atuais com olhar especial para as exportações de bens manufaturados e fazer tudo isso sem perder a sensibilidade social.

Siscú, Paula e Michel complementam que essa proposta do papel regulador do Estado não significa redução do Estado (como no liberalismo) e sim uma reconstrução do Estado tendo em vista o cenário atual no qual a iniciativa privada tem um postura mais ativa na economia. Consequentemente, o Estado fica liberado da postura empreendedora e pode reorganizar-se para atuar de forma mais capacitada no plano político, regulatório e administrativo, tornando-se mais forte e financeiramente mais sólido.

No governo do ex-presidente Luiz Inácio Lula da Silva, após quase três décadas de estagnação, tem-se uma inegável retomada do crescimento econômico. Embora alguns autores julguem que a recuperação do poder aquisitivo do salário tenha se dado de forma modesta (SAMPAIO JUNIOR, 2012), a significativa expansão de programas de transferência direta de renda a famílias em situação de pobreza e de extrema pobreza auxiliaram no aquecimento da economia. Consequentemente, os primeiros anos do século XXI são marcados pelo boom da chamada "classe C" que, notadamente, passou a ter acesso a produtos (como televisores modernos e celulares) e a serviços (como viagens de avião). Bresser-Pereira (2012) aponta que, juntamente com a ampliação dos empréstimos às empresas, dado pelo Banco Nacional de Desenvolvimento Econômico e Social (BNDES), o Bolsa-Família e o aumento do salário mínimo foram fatores fundamentais para que o Brasil tivesse fôlego para aumentar o consumo e não sucumbir à crise financeira global de 2008 .

Contudo, Sampaio Junior (2012), aponta que esses avanços não são indicadores de que o novo desenvolvimentismo constitui a chave para o enfrentamento das desigualdades sociais. Fazendo uma provocação, Oliveira (2003) fala que o Partido dos Trabalhadores, avalizado pela "socialização da política" gramsciana, ao se estabelecer no poder, pôs em prática políticas consideradas o "avesso do mandato de classes recebido nas urnas", se rendendo ao capitalismo periférico. As propostas eram intensamente reformista ${ }^{15}$, prometendo a socialização da política com alargamento na participação da população das decisões, avanços reais na problemática da redistribuição da renda, além da reforma política, objetivando por fim ao histórico patrimonialismo. Contudo, Oliveira (2003), bastante taxativo, opina que os resultados alcançados nos dois mandatos de Luiz Inácio Lula da Silva são o oposto do que o mandato avalizava.

\footnotetext{
${ }^{15}$ no sentido clássico que a sociologia política aplicou ao termo.
} 
Tanto para Sampaio Junior (2012), como para Oliveira (2003), ainda que se tenha avançado nas políticas sociais, no campo econômico, o neodesenvolvimentismo não se opôs a algumas práticas neoliberais. Sob esse aspecto, Sampaio Junior (2012), considera que o desenvolvimentismo se comporta como uma versão ultra light da tática de ajuste da economia brasileira aos imperativos do capital financeiro. Já Oliveira (2003), acredita que ”o governo Lula, na senda aberta por Collor e alargada por Fernando Henrique, só faz aumentar a autonomia do capital, retirando às classes trabalhadoras e à política qualquer possibilidade de diminuir a desigualdade social e aumentar a participação democrática.” (OLIVEIRA, 2003)

\subsection{Mito do (neo)desenvolvimentismo}

No seu livro "0 Mito do desenvolvimentismo", Furtado (1974) fez uma crítica à visão puramente economicista do período desenvolvimentista vivido no Brasil até a década de 1970. Embora faça duras considerações sobre a supervalorização de índices econômicos, o autor não nega todo o valor dos conceitos criados nessa época e não propõe substituí-los por outros. Ele apenas demonstra que o uso de índices como o PIB para avaliar o progresso do país é falacioso e faz parte de um discurso ideológico. Nesse sentido, há que se admitir que índices (como o PIB) podem ser alavancados não só por um suposto acúmulo de riqueza que beneficiará toda a nação, mas também por um crescimento desigual com o aumento da concentração de renda, beneficiando assim apenas poucos e, concomitantemente, iludindo muitos. Deste modo, o uso do aumento do PIB para demonstrar uma melhoria social e econômica geral da população pode ser caracterizado como um discurso ideológico e, consequentemente, um mito.

Sampaio Junior (2012) ratifica essa visão, ressaltando que ainda hoje muitos economistas ${ }^{16}$ supervalorizam os fatos considerados positivos do neodesenvolvimentismo e desconsideram os aspectos negativos. Assim, o debate fica centralizado nas estratégias de utilização dos instrumentos da política econômica, visando superar os entraves ao crescimento de forma a conciliar as exigências do equilíbrio macroeconômico com os

\footnotetext{
${ }^{16}$ Sampaio Junior (2012) recomenda ver a apologia neodesenvolvimentista feita na tese de doutorado de Aloísio Mercadante (As bases do novo desenvolvimentismo: análise do governo Lula - Instituto de Economia da Universidade Estadual de Campinas, Campinas, 2010).
} 
objetivos da política industrial e as necessidades orçamentárias da política social. No entanto, na maioria das discussões não se coloca a questão chave da dupla articulação: dependência externa e segregação social. Também não são considerados os pesos reais dos impactos negativos globais do capitalismo, nem a posição do Brasil na divisão internacional do trabalho. Logo, "alimentam a mitologia de que a economia brasileira estaria passando por um ciclo endógeno de crescimento com distribuição de renda e aumento da soberania nacional” (SAMPA1O JUNIOR, 2012, p.681).

Ao explicar o mito do progresso, ${ }^{17}$ Dupas (2007) argumenta que no final do século XX e início do século XXl, a vertiginosa evolução das tecnologias gerou inegáveis benefícios, como a possibilidade do ser humano de deslocar-se mais rápido, viver com saúde por mais tempo, comunicar-se instantaneamente e outros feitos. Porém, todas essas proezas são englobadas no discurso hegemônico do progresso trazido pela globalização juntamente com o discurso da necessidade incessante de crescimento. Com isso, a ideia de progresso se associa, não com a ideia de melhoria de qualidade de vida, mas com a ideia de expansão, de crescimento financeiro. Paradoxalmente, esse progresso (baseado nos índices econômicos) presente no discurso dominante das elites globais é acompanhado de exclusão; concentração de renda; graves danos ambientais; restrições e agressões aos direitos humanos essenciais. 0 progresso deixa de ser sinônimo de benefícios para a população e passa a ser renda para aqueles poucos que detêm o controle das decisões econômicas de uma nação. (DUPAS, 2007)

Para Dupas (2007), a necessidade de legitimação econômica permite ao sistema de dominação adapte-se às novas exigências. Assim, por vezes é necessário uma despolitização da grande massa da população e, para que essa legitimação econômica se torne plausível é que surge a ideologia do progresso técnico.A seguir, com base em atores como Furtado (1974) e Dupas (2007), iremos retomar a discussão sobre ideologia feita no início deste capítulo. Aplicaremos o conceito de ideologia a alguns aspectos do neodesenvolvimentismo e do desenvolvimentismo, tendo em vista que certos mitos estabelecidos em meados do século XX perduram no modelo atual. Para uma fácil leitura, separamos as ideias dos autores em três subtópicos:

Primeiramente, vamos focar nas argumentações de Furtado (1974), quais sejam: a) que seria falsa a noção de que um país subdesenvolvido só pode avançar seguindo o

\footnotetext{
17 No ensaio publicado na revista Novos Estudos número 77 em março 2007, no qual o autor sintetiza os principais temas do seu livro 0 mito do progresso, publicado em 2006 pela Editora da UNESP.
} 
modelo dos ditos países ricos; b) que o sistema econômico vigente não permite que todos os países tenham o mesmo padrão de crescimento e de consumo.

No segundo subtópico, passaremos para os argumentos com os quais se pontua que, embora o desenvolvimentismo e o neodesenvolvimentismo sejam contra a corrente liberal que privilegia a classe rentista (que vive de renda), eles privilegiam a classe burguesa (sobretudo a industrial). Esta, através dos aparelhos do Estado, usa argumentos (como a criação de empregos) para fazer com que grande parte da população acredite que as ações burguesas têm como objetivo os benefícios da coletividade, mesmo que em nada alterem a desigualdade de renda.

No terceiro, iremos abordar os prejuízos socioambientais trazidos pelo aumento da industrialização a qualquer custo feito pelo desenvolvimentismo. Para Furtado (1974), a industrialização desenfreada provoca a destruição de culturas "arcaicas" e a homogeneização cultural e, consequentemente, o empobrecimento cultural, além de irreversíveis danos aos recursos naturais.

\subsubsection{Neodesenvolvimentismo no contexto do capitalismo internacional}

A apropriação dos recursos naturais não renováveis se dá de forma desigual no capitalismo internacional (DUPAS, 2007). Nos últimos anos, a Ásia e a América do Norte foram responsáveis pela maior parte do crescimento do uso de combustíveis fósseis e, consequentemente, da emissão de gases que contribuem para o efeito estufa. Algumas estimativas indicam que os Estados Unidos produzem dez vezes mais gás carbônico per capita que a média dos países em desenvolvimento. 0 autor informa que desde 1960, um quinto das florestas tropicais desapareceram e, mesmo sabendo o quão é elevado o custo para reverter a degradação, as ações de degradação continuam constantes.

Reforçam-se os indícios de que as emissões de gases de combustíveis fósseis estão tendo forte impacto no aquecimento global e causando derretimento acentuado do gelo polar. A Revolução Industrial foi o marco da mudança de tendência, quando se começou a queimar pesadamente carvão e óleo, produzindo os gases causadores do efeito estufa. Só no último século, a concentração de gás carbônico subiu de 260 para 380 partes por milhão (ppm) e a temperatura média do planeta elevou-se em 0,7 graus Celsius (DUPAS, 2007,p.85).

Bertucci et al. (2002) mantêm uma posição crítica ao desenvolvimentismo similar à de Furtado (1974). Os primeiros chamam de "ilusão" e "engodo" o que Furtado caracterizou 
como "mito" e "ideologia" respectivamente. Eles afirmam que o termo "desenvolvimento" revela-se como parte de um engodo construído a partir de duas ilusões (ou contradições) básicas. A primeira se refere à hipótese da existência de uma única trilha (sem qualquer possibilidade de bifurcação) a ser seguida pelos diferentes países (independentemente das suas características e peculiaridades) para atingir o tão aclamado desenvolvimento. Lideram esse caminho os que se auto proclamam como "países desenvolvidos" e devem percorrer rápido o mesmo longo trajeto os chamados "países em desenvolvimento", qualquer que seja a sua história. Como consequência, tem-se a segunda llusão. Esta se refere à hipótese fantasiosa de que no planeta existam condições ambientais para que todos alcancem o ponto de chegada da trilha."Isto é, consigam, antes tarde do que nunca, se encaixar no modelo que se pretende ideal. E aí os problemas se adensam: afinal, que modelo é esse?" (BERTUCCl et al., 2002, p.14).

Cabe lembrar que este modelo se baseia numa divisão internacional do trabalho, no qual cada um tem um papel bem definido e ordenado por aqueles que já chegaram no final da trilha. Assim, a conjuntura política econômica mundial, baseada no sistema capitalista, pressupõe a existência de patamares de desenvolvimento econômico, sendo impossível a manutenção de todos os países no primeiro patamar. Contudo, Furtado (1974) reforça que, com a publicação do Clube de Roma, ficou claro e irrefutável que os países da periferia nunca serão desenvolvidos como os países centrais.

Por isso, Bertucci et al. (2002) colocam que o engodo é ainda maior se pensarmos que difunde-se a ideia de que todos poderão atingir esses padrões impostos como ideais, desde que sigam certas regras econômicas. Tais regras são propagadas sem questionamentos, sem análise, sem pensar se essa é a melhor forma de crescer ou ainda em quem as definiu. No atual mundo tecnológico, a escada do crescimento e do consumo parece infinita. Bem como Furtado (1974), os autores concluem que não importa quanto os países subdesenvolvidos se esforcem, o fosso da desigualdade entre essas nações e o resto do mundo não diminui, só cresce.

De acordo com Dupas (2007), importantes cientistas afirmam que a população mundial continuará crescendo até 2050, quando terá atingido de oito a nove bilhões de pessoas. Pelas estimativas, para todos atingirem o mesmo padrão da elite atual seriam necessários quase três planetas Terra com seus recursos naturais existentes. Dupas (2007) aponta que fica claro que a ideia de progresso para todos esbarra no fato de que será 
impossivel a toda essa massa humana alcançar o padrão de vida médio equivalente ao do europeu e do norte-americano atual.

Quarenta anos atrás, Furtado (1974), analisando o cenário político do capitalismo na época, previa que a crescente concentração da renda no centro do sistema se constituiria como um fator adicional do aumento da pressão sobre os recursos não reprodutíveis.

Recentemente, tendo como base dados do imposto de renda de mais de vinte países em todo o mundo, Piketty (2014) comprova que essa concentração de renda chegou a níveis extremos. Para este autor, um determinado nível de desigualdade de renda pode ser necessário e útil para viabilizar inovações empresarias e crescimento econômico, desde que também sirva aos interesses dos segmentos mais pobres das sociedades. 0 problema é que, nos dias atuais, temos uma situação de excessiva desigualdade. Os dados da organização não governamental OXFAM também apontam para essa situação alarmante, prevendo que em 2016 um por cento da população mundial deterá cinquenta por cento de toda a riqueza do mundo. (ROSSI, 2015)

Piketty (2014) coloca que, do ponto de vista estritamente econômico, esse padrão de acumulação poderá continuar se reproduzindo dentro do sistema capitalista. Contudo, caso isso ocorra, o altíssimo nível de desigualdade e de perpetuação da concentração de capital pode acarretar em problemas políticos, com o comprometimento das instituições democráticas. Assim, Piketty (2014) faz um alerta para que as instituições democráticas repensem, entre outras, as políticas sociais, trabalhistas e fiscais, sobretudo no que diz respeito aos impostos progressivos sobre grandes rendas e heranças.

Para Furtado (1974), a grande desigualdade dos padrões de consumo é o principal fator que faz com que o planeta não colapse, com que a pressão sobre os recursos naturais não reprodutíveis seja substancialmente inferior à que está na base das projeções ambientalistas alarmistas. 0 fator secundário se refere à falta de disponibilidade de terra arável a ser utilizada no contexto da agricultura de subsistência, ou seja, à ideia de freio malthusiano.

Ainda que existam esses freios, essas projeções e previsões de ruptura cataclísmica, "proporciona uma demonstração cabal de que o estilo de vida criado pelo capitalismo industrial sempre será o privilégio de uma minoria” (FURTADO, 1974, p.76). É a partir delas que este estilo de vida tem altos custos de depredação do mundo físico e, sendo assim, não só devemos repensá-los, como a tentativa de generalização levaria inexoravelmente ao colapso, pondo em risco a sobrevivência da espécie humana como um todo. Tem-se assim, 
o que Furtado considera como "a prova cabal de que o desenvolvimento econômico - a ideia de que os povos pobres podem algum dia desfrutar das formas de vida dos atuais povos ricos - é simplesmente irrealizável”. Fica claro então, que não só a ideia de "desenvolvimento para todos" é um mito, como também que essa ideia da necessidade de crescimento é parte de um discurso ideológico que, na verdade, é usado de forma a manter a desigualdade. Esse mito faz com que a população mais periférica (em geral os grandes empreendimentos desenvolvimentistas não abalam os ricos dos países periféricos, e sim, os pobres dos países já atrasados) aceite os sacrifícios das destruição cultural, social e ambiental em nome de um suposto "benefício coletivo".

Em 1974, vendo emergir questionamentos quanto ao modelo de consumo planetário, Furtado afirmou que graças a esses cálculos alarmantes e a modelos como os expostos no livro "The limits to growth" (1972), foi viável comprovar esse mito e foi possível desviar as atenções desse conceito irrefutável do desenvolvimento (e de seus objetivos abstratos, como investimentos, exportações e crescimento) e voltar a atenção para a tarefa básica de identificação das necessidades fundamentais da coletividade, analisando as possibilidades de atendê-las frente ao avanço da ciência.

Analisando o século XXl, Harvey (2014) faz uma leitura mais atual do que a de Furtado (1974). Ele comenta que a ideia de que o capitalismo estaria entrando em contradição devido à crise ambiental pode ser questionada, sobretudo, devido a quatro pontos. Primeiramente, Harvey coloca que o capital tem uma longa experiência em resolver com sucesso as suas dificuldades ecológicas e que há muito vem sendo dito que o crescimento do capitalismo esbarrará em uma catástrofe socioambiental (como a teoria Malthusiana de 1798, o livro" the limits to growth" de 1972, entre outros), mas até hoje o capitalismo em si, não foi substancialmente colocado em xeque.

Pela exposição feita por Dupas (2007), esse pensamento aparenta ser uma tendência entre os cientistas. Parece haver um consenso de que é ingênua a ideia de colapso geral do planeta por conta da superexploração capitalista dos recursos naturais. Há concordâncias de que a manutenção desse modelo econômico causará prejuízos socioambientais para algumas sociedades, ou partes de sociedades, mas não para toda a humanidade. As classes dominantes, sobretudo as dos países centrais, encontrarão maneiras de não serem atingidas pelos malefícios dos seus estilos de vida. Dupas mostra que há hoje duas correntes: uma que busca medidas de prever e gerir os danos e outra mais radical que propõe que se renuncie às ações que colocam em risco a vida humana futura. 
A maioria dos cientistas considera que nem mesmo as mais rigorosas mudanças climáticas concebíveis destruiriam diretamente toda a humanidade, mas algumas delas poderiam anular décadas de avanço econômico e social. Para Paretti-Watel, 'não se trata mais de eliminar o risco, mas, mais modestamente, de geri-lo'. É o princípio da precaução, incluído em diversos tratados internacionais. Esse princípio afirma que 'na ausência da certeza científica formal, a existência de um risco de um dano sério ou irreversivel requer a implementação de medidas que possam prever este dano'. 0 princípio da precaução é muitas vezes confundido com o princípio da responsabilidade de Hans Jonas, que exige que se renuncie à ação, desde que ela inclua riscos de colocar em perigo uma vida humana futura. 0 direito humano fundamental de longo prazo é o do direito à existência como espécie (DUPAS, 2007,p.86).

O segundo ponto de Harvey (2014) explica que a questão ambiental não limita o capitalismo porque ela é internalizada na circulação e acumulação de capital. As práticas capitalistas não visam mais "dominar a natureza", e sim integrar-se a elas. Nesse sentido, Harvey coloca que o capitalismo é um sistema que se mantém trabalhando e evoluindo, no qual tanto a natureza como o capital estão constantemente sendo produzidos e se reproduzindo. logo, o atual ecossistema é construído a partir da união contraditória entre capital e natureza, na mesma forma que a mercadoria é uma unidade na qual estão os valores contraditórios de uso e de troca, tal qual colocado por Marx no livro "O Capital". Harvey (2014) expõe que nos últimos três séculos entramos em uma fase em que o Capital reconfigura e recria o seu ambiente, produz ativamente uma natureza propícia para o seu estabelecimento e para sua própria reprodução. Contudo, essa recriação não necessariamente é feita em benefício de toda a humanidade e, algumas delas podem até vir a se tornar maléficas para a saúde humana.

Lembrem-se, também, da definição de tecnologia como uma apropriação humana das coisas e dos processos naturais para facilitar a produção. A natureza que resulta é algo que não está apenas evoluindo de forma imprevisivel a sua própria vontade (por causa das mutações aleatórias autônomas e interações dinâmicas incorporadas ao processo evolutivo em geral), mas também está ativa e constantemente sendo reformulada e re-projetada pelas ações do Capital. Isto é o que Neil Smith chamou de "a produção da natureza" e hoje em dia é a produção até o nível de biologia molecular e seqüenciamento de DNA. 0 sentido desta produção da natureza leva a um processo aberto e não uma questão fechada. Também tem sido evidente que há muitas consequências inesperadas. Os frigoríficos que facilitaram a entrega de alimentos contaminados para as crescentes populações urbanas foram muitos anos mais tarde identificados como a fonte dos clorofluorocarbonetos - CFC - que estavam destruindo a camada de ozônio 
estratosférica que nos protege da radiação solar excessiva! (HARVEY, 2014, p.236) (tradução livre de Ticianne Ribeiro de Souza) ${ }^{18}$

0 terceiro ponto de Harvey (2014), como consequência do segundo ponto, é que o capital transformou questões ambientais em um grande negócio. A cada dia aparecem novas soluções ambientais. "Salvar a natureza" é um novo mercado em expansão, que já foi englobado em vários setores do capitalismo, seja na indústria de produtos "eco-friendly" 19 , que ganham da sua concorrência por ter algum componente da sua produção que cause menos prejuízo ao meio ambiente, seja nas estratégias de marketing conhecidas como "greenwashing" ${ }^{20}$, que vão desde uma simples mudança em uma embalagem, para que ela se pareça com a embalagem de um produto "eco-friendly", até a criação de programas de mitigação de impactos ambientais com resultados mais significativos. Nesse sentido, Harvey (2014) destaca que as tecnologias ambientais são agora um item caro nas bolsas de valores do mundo. Assim, na atualidade há que se avaliar a finalidade de qualquer projeto que se diz de alguma forma ecológico. A quem ele mais beneficia? Ao bem-estar das pessoas ou à taxa de lucro? Veremos ao longo do presente trabalho que estas são questões centrais também no caso do AMRJ.

0 quarto ponto do autor é, talvez, o pensamento mais desconfortável de todos, tamanha sua desconexão com os valores humanitários. Harvey (2014) cita vários incidentes desastrosos para deixar claro que é perfeitamente possível para o capital continuar a circular e se acumular em meio a catástrofes ambientais. Os desastres ambientais não são necessariamente um problema para a reprodução do capital, pelo contrário, neles se criam oportunidades abundantes para lucrar generosamente. 0 "capitalismo de desastre" vê as mortes por fome das populações expostas e vulneráveis e a maciça destruição do habitat não como um empecilho (a menos que provoque rebelião ou revolução anticapitalista), mas sim como uma possibilidade de gerar lucros na reconstrução do local ou na resolução de

${ }^{18}$ Texto original em inglês: "Recall, also, the definition of technology as a human appropriation of natural things and processes to facilitate production. The nature that results is something that is not only evolving unpredictably of its own accord (because of the autonomous random mutations and dynamic interactions built into the evolutionary process in general) but actively and constantly being reshaped and re-engineered by the actions of capital. This is what Neil Smith has called 'the production of nature' and these days it is production 'all the way down' in to the level of molecular biology and DNA sequencing. The direction this production of nature takes is an open and not a closed question. It has long been apparent, also, that it is full of unintended consequences. The refrigerators that facilitated the delivery of on contaminated food supplies to burgeoning urban populations were many years later identified as the source of the chloro-fluorocarbons CFCS - that were destroying the stratospheric ozone layer that protects us from excessive solar radiation!"

${ }^{19}$ Termo em inglês que significa ecologicamente amigáveis.

${ }^{20}$ Termo em inglês que significa "lavagem verde". Sua origem está associada a um artigo da revista New Scientist, publicado em 1989. Neste artigo, o termo greenwashing fazia uma analogia ao termo brainwashing, que em português significa lavagem cerebral. 
alguma questão ambiental. 0 autor lembra que na lógica do lucro capitalista, a massa de população pobre, com baixo padrão de consumo é descartável e, mais do que isso, ”o capital nunca se retraiu ao destruir as pessoas em busca do lucro" (HARVEY, 2014, p.236) ${ }^{21}$

\subsubsection{Neodesenvolvimentismo para quem?}

De acordo com Dupas (2007), os danos ambientais decorrentes das ações das corporações tornaram-se mais problemáticos a partir da segunda metade do século XX, com a intensificação do setor industrial. 0 cenário se agrava ainda mais com um período de liberdade quase absoluta das empresas no que tange à criação de produtos ou serviços transformados em objetos de desejo dos consumidores, visando à manutenção da lógica da acumulação, essencial à produção de riqueza no capitalismo. Dupas (2007) conta que a conferência internacional Rio-92 foi o primeiro grande espaço de debate no qual empresas e governos, por estarem na mira dos ambientalistas, concordaram em considerar parâmetros ambientais em suas variáveis de planejamento público e mercadológico. No entanto, aqueles compromissos não impediram que o modelo global de produção seguisse contribuindo para o progressivo aumento da degradação ambiental.

A partir da observação do comportamento dos agentes que controlam os principais centros do poder, Furtado (1974) explica que podemos, mediante a análise macroeconômica, verificar como os que mandam falam em nome da coletividade. Afinal, os que exercem o poder derivam sua autoridade do consenso das maiorias ou da simples repressão. Contudo, na hipótese democrática do consenso, há que se levar em consideração o habitual uso ideológico de manipulação da informação e da interação de forças sociais.

Essa manipulação tem origem no desejo pelo crescimento do lucro. Logan e Molotch (1987) pontuam que a cidade é vista pela classe industrial e pela classe rentista como local de produção e de fonte de renda enquanto para os seus habitantes ela é local de moradia e lazer. Tem-se, então, uma situação de conflito entre aqueles que se interessam pelo valor de uso do espaço e aqueles que interessam pelo valor de troca que pode surgir da especulação dele (classe rentista) ou da apropriação dele para a produção (classe industrial).

\footnotetext{
${ }^{21}$ tradução livre de Ticianne Ribeiro de Souza. Texto original em inglês: "And capital has never shrunk from destroying people in pursuit of profit."
} 
Para os urbanistas da Escola de Chicago, as cidades crescem pela sua capacidade de fazer uma contribuição positiva para o sistema maior de cidades, sendo cidades bem sucedidas aquelas que têm vantagens especiais, como um porto de águas profundas, como é o caso de Nova lorque, ou fácil acesso aos mercados, a matérias-primas e posicionamento central no país, como a cidade de Chicago (LOGAN; MOLOTCH, 1987). Conforme colocado por Ferreira (2007), ${ }^{22}$ à ideia de marketing urbano está alinhada com essa visão da Escola de Chicago. Para os defensores do marketing urbano as cidades devem fazer um planejamento estratégico focando nas suas "vocações" e procurando fazer campanhas para se promoverem no mercado internacional de cidades globais.

Discordando da Escola de Chicago, Logan e Molotch (1987) defendem que há uma relação entre a estrutura marxista de classes e os processos de urbanização e de acumulação do capital. E que existem coalizões entre as classes, sobretudo entre aquelas que têm o mesmo interesse, que visam o valor de troca, o mercado. Portanto, os autores assinalam que é o mercado que molda a paisagem urbana e as "vocações". Consequentemente, é ele também que altera as relações pessoais, para ter como resultado uma melhor ordenação da ocupação humana que atenda aos interesses do mercado de funcionamento harmonioso do seu sistema.

Os autores reforçam que um lugar tanto é definido por sua posição organizacional (político, econômico e cultural), como por sua constituição física e topográfica. 0 espaço tem características físicas inerentes, mas também tem características físicas construídas e identificações de construções sociais. Para eles, são as relações sociais de classes que transformam esse lugar, e não o contrário. Dentre muitos casos, citam a África do Sul, local em que a característica física inerente de existência de diamantes só foi transformada em mercadoria após a exploração colonial de uma minoria branca sobre uma maioria negra, que nada ganhou com esta extração mineral da sua terra.

Outro exemplo curioso do processo de formação de um local é o caso de Chicago, onde a coalizão entre o setor privado e o setor público se deu por um único homem: William Ogden. Em 1983, a cidade tinha menos de quatro mil habitantes. Foi quando William Ogden chegou a Chicago e comprou propriedades e também algumas ferrovias. Pouco tempo depois, ele tornou-se prefeito e combinou as suas funções cívicas com os seus interesses empresariais. Para suposto benefício dos poucos habitantes de Chicago e em

\footnotetext{
${ }^{22}$ Ferreira, J. 0 mito da cidade global: o papel da ideologia na produção do espaço urbano. São Paulo: Vozes/Editora da UNESP/ANPUR, 2007.
} 
nome do seu "dever público", o prefeito Ogden investiu em ferrovias que transformaram a pequena Chicago no cruzamento da América. Construindo assim, uma verdadeira fortuna para si através das alterações de uma cidade que os alunos da Escola de Chicago caracterizaram como possuidora de "vocação" para centralidade.

Chicago se tornou uma encruzilhada, não só porque era "central" (outros locais também estavam no "meio"), mas porque um pequeno grupo de pessoas (liderada por Ogden) tinha o poder de, literalmente, fazer com que os caminhos se cruzassem no local que eles escolheram. Ogden espontaneamente comentou sobre um dos seus negócios imobiliários viabilizados por esses cruzamentos de ferrovia: "Eu comprei por \$ 8,000, e oito anos depois, vendi por 3 milhões de dólares" (Boorstin, 1965: 117). A história Ogden, diz Boorstin (p 118). "foi reencenada mil vezes em toda a América" (LOGAN; Molotch, 1987, p.54-55). (tradução livre de Ticianne Ribeiro de Souza) ${ }^{23}$

Com o exemplo de Chicaco, fica claro que a influência sobre a máquina pública pode render benefícios significativos a quem conseguir direcionar os investimentos do Estado segundo seus interesses de rendimento financeiro. Cabe ressaltar que as principais questões aqui colocadas por Logan e Molotch (que mais à frente serão retomadas na análise do caso do Arco Metropolitano por serem também centrais para o presente trabalho), são: era uma necessidade desses quatro mil habitantes que a sua cidade fosse transformada em centralidade de um sistema de ferrovias? Quem fez a opção por essa transformação? Quem de fato se beneficiou com ela? Logan e Molotch (1987) afirmam que a questão: "quem governa?" ou "quem cria as regras?" tem que ser feita juntamente com a seguinte pergunta: "com que objetivo o faz?" Segundo eles, com raras exceções, a questão do crescimento nas localidades tende a ser consenso entre as elites, mas não entre as pessoas que usam a cidade como um lugar para morar e trabalhar. Boa parte das elites vê a cidade como uma "máquina de crescimento" ${ }^{24}$, que pode aumentar as suas rendas imobiliárias ou empresariais. Não importa o quanto os diversos grupos da elite sejam diferentes e divididos no que tange a outras questões, eles sempre terão o desejo de crescimento do seu lucro.

Quem efetivamente detém o controle da cidade é, portanto, uma questão fundamental, ainda mais se os objetivos fixados por quem governa forem

\footnotetext{
${ }^{23}$ Texto original em inglês: "Chicago became a crossroads not only because it was 'central' (other places were also in the 'middle') but because a small group of people (led by Ogden) had the power to literally have the roads cross in the spot they chose. Ogden candidly reminisced about one of the real estate deals this made possible: '1 purchased for \$8.000, what 8 years thereafter, sold for 3 millions of dollars' (Boorstin, 1965: 117). The Ogden story, Boorstin says (p. 118), 'was re-enacted a thousand times all over America' (LOGAN; MOLOTCH, 1987, p.54-55). "

${ }^{24}$ Conceito utilizado inicialmente em paper individual de Harvey Molotch, "The city as a growth machine", em 1976.
} 
exatamente os de transformá-la em uma máquina de crescimento que pode gerar significativos ganhos agregados (FERREIRA, 2007, pág.153, grifo do autor).

Conforme observado por Ferreira (2007), é justamente por ter essa visão de classes que a teoria da "máquina de crescimento" consegue explicar uma dinâmica local, mas também evidenciar como muitas vezes os fenômenos macroeconômicos são apropriados em favor dos atores mais poderosos ou da união de atores das classes mais ricas. Esse raciocínio leva à construção da hipótese de que, independentemente do grau de influência das dinâmicas macroeconômicas (globais ou não), o processo de produção do ambiente responde, antes de tudo, a uma dinâmica socioeconômica e política de âmbito local. $\mathrm{Ou}$ seja, ainda que se mude a conjuntura internacional, um Estado patrimonialista sempre obedecerá os desejos da sua Elite. A influência das dinâmicas macroeconômicas globais se daria na medida que elas possam, de alguma maneira, exacerbar os processos locais. Os interessados no espaço pelo seu valor de troca criam coalizões em torno de um objetivo específico. Essas coalizões podem envolver o setor industrial, os proprietários fundiários, os políticos locais, a mídia, as agências de serviços públicos, setores sindicais, instituições culturais, etc., ou seja, todos aqueles que tenham algo a ganhar com o "crescimento" da cidade.

\footnotetext{
"O poder político dessas coalizões torna as cidades verdadeiras 'empresas devotadas ao crescimento da renda agregada através da intensificação do uso do solo urbano'. É a 'máquina de crescimento urbano'”(FERREIRA, 2007, p.152. grifo do autor).
}

Desta forma, no contexto do neodesenvolvimentismo, podemos dizer que o crescimento industrial em uma determinada localidade se dá por uma coalizão local que aproveita as dinâmicas macroeconômicas nacionais e se conforma como uma "máquina de crescimento", fazendo com que a industrialização local ganhe força para uma transformação regional. Podem ser exemplos brasileiros o Porto de SUAPE, concebido como "porto-indústria" (que vincula o setor logístico ao setor industrial, contando hoje com mais de 100 empresas em operação) e o Porto de Itaguaí, que possui a mesma dupla função. Cabe lembrar que não é por acaso que esses dois portos-indústrias conseguiram verbas públicas para serem construídos no momento em que havia alinhamento partidário entre os seus respectivos estados e um governo federal neodesenvolvimentista, proporcionando assim um forte peso político em acordo com a coalizão de setores privados favoráveis à instalação desses porto-indústrias economicamente significativos. Para Ferreira, ”à medida que coalizões são mais fortes, conseguem impor seus objetivos e apropriar-se do espaço que 
não se conforma portanto naturalmente apenas como uma 'lei de mercado'" (FERREIRA, 2007, pág.152).

Para Furtado (1974), o Estado desenvolvimentista se apoiou em grandes empresas (nacionais ou multinacionais) para garantir a sua estabilidade econômica. Essa relação quase dependente faz com que, mesmo que os Estados se preocupem com os interesses coletivos, a sua ação no campo social só será plena à medida que as questões econômicas ganhem estabilidade. Nesse contexto, o Estado desgasta-se com essa dupla-função de ora criar atrativos para as grandes empresas e ora preservar o meio ambiente e investir em algum benefício para a população.

\subsubsection{Neodesenvolvimentismo e a questão socioambiental}

Como vimos, diversos autores mostram que os índices que medem o "desenvolvimento" do Brasil (como o PIB) não retratam a concentração de renda e a desigualdade social e, assim, nada informa sobre a melhoria de vida da população. Logan e Molotch (1987) salientam que a "contribuição para a base tributária" pode ser publicizada como algo necessariamente benéfico para o bem-estar social de uma cidade. Contudo, essa não é uma relação direta de causa e efeito. Apenas após uma análise cuidadosa de cada localidade e dos seus impactos é que pode-se chegar a conclusões precisas sobre os benefícios sociais das contribuições tributárias de um novo empreendimento.

Em contrapartida, Bresser-Pereira (2012) faz uma análise de grandes teóricos do desenvolvimento como Celso Furtado, Raul Prebisch e lgnacy Sachs e conclui que eles sempre enfatizaram que o desenvolvimento implica mudanças estruturais em toda a sociedade. Assim, para ele, o desenvolvimento econômico é historicamente acompanhado por desenvolvimento político, por desenvolvimento social e por desenvolvimento ambiental. Bresser-Pereira deixa claro que "o desenvolvimentismo é a ideologia e é a estratégia desse desenvolvimento econômico que, na medida em que avança, se quer também ser social e ambiental” (BRESSER-PEREIRA, 2012, p.15).

Já Sampaio Junior (2012) acredita que o neodesenvolvimentismo comete um vulgar reducionismo economicista ao renunciar à problemática do desenvolvimento, ocultando conflitos estruturais de classe. Ele ainda faz uma crítica aos autores neodesenvolvimentistas que reivindicam explicitamente o legado de Furtado sem mencionar sua implacável crítica à 
perspectiva economicista para o entendimento dos problemas do desenvolvimento. Já em 1974, Furtado definia sua posição comentando:

Não é minha intenção abordar aqui, em detalhe, o problema da especificidade dessa industrialização fundada na chamada "substituição de importações"; limitar-me-ei a assinalar que ela tende a reproduzir em miniatura sistemas industriais apoiados em um processo muito mais amplo de acumulação de capital. Na prática, essa miniaturização assume a forma de instalação no país em questão de uma série de subsidiárias de empresas dos países cêntricos, o que reforça a tendência para reprodução de padrões de consumo de sociedades de muito mais elevado nível de renda média. Daí resulta a conhecida síndrome de tendência à concentração da renda, tão familiar a todos os que estudam a industrialização dos países subdesenvolvidos (FURTAD0, p.27-28).

Assim, Sampaio Junior (2012) afirma ainda que os defensores do novo desenvolvimentismo não possuem uma perspectiva totalizante da política econômica, o que acarreta na não percepção da complexidade da teia institucional. Esta teia envolve de forma engenhosa o Estado brasileiro, atando-o aos interesses do grande capital internacional e nacional e, consequentemente, perpetuando a dupla articulação entre dependência externa e segregação social. Com isso, o autor critica duramente a teoria neodesenvolvimentista pela incongruência entre o que esta teoria pensa ser e o que ela de fato é. Para Sampaio Junior, ela acredita ser uma alternativa qualitativa de desenvolvimento com capacidade de resolver os problemas renitentes da pobreza e a dependência externa. No entanto, ela na verdade é "apenas uma nova versão da surrada teoria do crescimento e da modernização acelerada como solução para os problemas do Brasil. Nada mais do que isso" (SAMPAIO JUNIOR, 2012, p.685).

Na visão de Sampaio Junior, ainda que de fato os neodesenvolvimentistas acreditem que estão propondo uma solução para a pobreza, estão na verdade ressuscitado uma teoria que acaba por disfarçar uma apologia do status quo vigente. Essa teoria cumpre uma função ideológica política ao diferenciar os últimos presidentes do Partido dos Trabalhadores (PT) com os mandatos neoliberais que os antecederam. Com isso, reforça ”o mito do crescimento como solução para os problemas do país, iludindo as massas" (SAMPA10 JUN1OR, 2012, p.686). Para o autor, a correta retomada da tradição crítica do pensamento latino-americano deve superar a ilusão da existência de uma solução burguesa para os problemas de subdesenvolvimento e dependência da América Latina.

Bertucci et al. (2002) ressaltam o fato de que a persistência desse ambiente de desigualdade e pobreza é muito marcante há muitas décadas. Isso fica claro, por exemplo, ao observar o coeficiente de Gini (índice que mede o grau de concentração da renda de um 
país, cuja desigualdade é tanto maior quanto mais se aproxima do marco 1). Ainda que Piketty (2014) já tenha mostrado que sua análise sobre a desigualdade (com base nos dados do imposto de renda) seja mais precisa que o índice Gini, o Brasil ainda não possui análise realizada com a metodologia de Piketty (2014), motivo pelo qual adotaremos aqui apenas o coeficiente Gini.

Segundo Bertucci et al. (2002) em 1960, o coeficiente brasileiro era 0,50. Em 1970, saltou para 0,59, chegando a aumentar ainda mais em meados da década de 1970. Entre 1978 e 2001 o coeficiente de Gini teve grandes oscilações chegando a bater 6,36. Assim, em 2002 Bertucci et al. se mantiveram céticos com relação às melhorias sociais e lembram que por diversas vezes a população aceitou as imposições do governo pela famosa promessa, difundida na década de 1970, de que o "bolo" primeiro teria que "crescer", mas que seria dividido depois de crescer. Com a alta do índice Gini até o final do século, os autores concluíram que os momentos de crescimento econômico resultaram em maior, e não em menor concentração de renda. Contudo, dados mais recentes do Instituto de Pesquisa Econômica Aplicada (IPEA, 2014) ${ }^{25}$ mostram que, entre 2001 e 2013, o índice apresentou queda constante, chegando à marca de 0,53 em 2013. Essa queda pode ser uma consequência dos programas de transferência direta de renda. Porém, lembramos que os países já analisados pela metodologia utilizada por Piketty (2014) mostraram uma situação de concentração de renda mais exacerbada do que o coeficiente de Gini apontava.

Segundo Logan e Molotch (1987), para manter a máquina de crescimento em constante movimento, as empresas participantes das coalizões se apoiam em ideologias que ajudam a torná-las respeitadas em sua área. Muitas vezes, o seu valor social é definido em termos de "tamanho da folha de pagamento". Sua folha de pagamento, por sua vez, ajuda a obter subsídios públicos. Desta forma, estes empresários ganham benefícios e publicidade na mídia com status de quem está fazendo um "favor" à sociedade, ao gerar tantos empregos. Entretanto, Logan e Molotch lembram que, enquanto a geração de emprego ganha destaque na mídia, os benefícios nos lucros e as altas rendas raramente são levados a público.

Como vimos, uma das diferenças fundamentais entre o velho e novo desenvolvimentismo é que no primeiro a economia brasileira transitava de uma economia agroexportadora para uma economia industrial. Deste modo, o foco das políticas públicas

\footnotetext{
${ }^{25}$ Calculado a partir das respostas à Pesquisa Nacional por Amostra de Domicílios (Pnad/lBGE). Atualizado em: $04 / 11 / 2013$
} 
era a balança comercial, visando diminuir a dependência da exportação de produtos primários e desenvolver uma industrialização consistente. Já o novo desenvolvimentismo, para Siscú, Paula e Michel (2007), pretende um Estado forte, preocupado em estabelecer o controle das contas econômicas do país através do crescimento econômico, tendo como desafio fazer isso de forma compatível com políticas de equidade social, visando reduzir as desigualdades sociais.

Economias bem-sucedidas em termos de crescimento e equidade compartilham uma característica básica, que é a incorporação do progresso técnico e elevação da produtividade. Neste contexto, em função das insuficiências no âmbito da equidade e da baixa incorporação do progresso técnico em setoreschaves da indústria, o crescimento econômico e a competitividade apresentaram um comportamento claramente espasmódico na América Latina (Siscú, Paula e Michel, 2007, p.7).

Pelo o que observam logan e Molotch (1987), não foram apenas os países da América Latina que tiveram problemas em conciliar benefícios econômicos com benefícios sociais no que diz respeito à industrialização. A ideia da criação de novos postos de trabalho deve sempre ser analisada em uma escala macro. 0 deslocamento de indústria, ou locação dela em um estado em detrimento do outro (ou seja, o crescimento local) não gera empregos: só os distribui. Os autores citam várias pesquisas que mostraram que, em uma análise nacional, a instalação de (em exemplo adaptado à realidade brasileira) uma grande empresa automobilística em uma cidade industrial paulista ou próximo a um novo complexo portuário de outro Estado, não resulta significativamente em alteração da taxa de desemprego do país. Assim, a competição entre estados pela "criação de novos empregos" não traz nenhum benefício econômico para o país. Contudo, cabe lembrar que é interessante a instalação industrial em cidades que possuem localmente alta taxa de desemprego e que a mão de obra disponível é compatível com os empregos a serem criados. lsso também é importante para evitar, entre outros, problemas de mobilidade para os trabalhadores que teriam que realizar migrações interurbanas e problemas de falta de infraestrutura urbana devido à chegada de uma grande quantidade de trabalhadores em busca de moradias próximas ao seu novo posto de trabalho.

0 emprego agregado não é afetado pelo resultado desta concorrência entre as localidades em "criar" empregos. A maior parte dos estudos que buscam, através de análise transversal ou longitudinal, as relações entre as taxas de crescimento dos lugares e as taxas de desemprego não mostram relações significativas (Applebaum, 1976; Follett, 1976; Garrison, 1971; Greenberg, nd; Hadden e Borgatta, 1965: 108; Samuelson, 1942; Sierra Club de San Diego, 1973; 
Summers et al, 1976; Summers e Branch, 1984; mas ver Eberts, 1979). (tradução livre de Ticianne Ribeiro de Souza) ${ }^{26}$

Assim, a partir da análise de Logan e Molotch (1987), vemos que a oferta de emprego, por si só, não significa melhorias sociais, podendo até agravar, nos dias atuais, problemas sociais relacionados sobretudo à habitação, à mobilidade e à infraestrutura urbana. Os autores citam os estudos de Lieberson (1980), ${ }^{27}$ que chegou à conclusão que o crescimento das cidades industriais americanas no início deste século XX, levou a grandes concentrações populacionais e, consequentemente, aumentou a segregação espacial e social entre ricos e pobres, negros e brancos. A geração de emprego só passa a ser um benefício para a sociedade como um todo quando ela é feita de forma estratégica, levando em consideração os excedentes de mão de obra de cada localidade e a compatibilidade desses excedentes com o tipo de empreendimento a ser implantado naquele local. Em uma análise sobre o mesmo tema, com foco no crescimento industrial em pequenas cidades, Summers e Branch (1984) relatam que os incrementos para a base tributária local gerados pelo aparecimento de novas indústrias foram, na maioria dos casos, compensados pelos encargos adicionados de serviços, exceto quando o desenvolvimento industrial não foi subsidiado pelo governo local e novos empregados continuaram a viver em outras comunidades, não ocorrendo migrações.

Bem como acontece com a distribuição de renda, no espaço urbano, "a dominação social se faz mediante desigual distribuição, entre as classes sociais, dos frutos do trabalho" (VILLAÇA, 2009). Dentre os fatores causadores de valorização diferenciada do meio urbano estão também os recursos públicos investidos em infraestrutura, que muitas vezes ocorrem de forma concentrada em determinadas áreas das cidades. Assim, essa segregação cria uma excepcional vantagem para os mais ricos e um ônus excepcional para os mais pobres. Ferreira e Ferrara (2012) lembram que a segregação espacial das cidades brasileiras expõe a população de mais baixa renda aos maiores riscos, conformando uma injustiça socioambiental decorrente da desigualdade locacional.

\footnotetext{
${ }^{26}$ Texto original em inglês: ;"Aggregate employment is unaffected by the outcome of this competition among localities to "make" jobs. The bulk of studies that search, either through cross-sectional or longitudinal analysis, for relations between size or growth of places and unemployment rates fail to show significant relationships (Applebaum, 1976; Follett, 1976; Garrison, 1971; Greenberg, n.d.; Hadden and Borgatta, 1965:108; Samuelson, 1942; Sierra Club of San Diego, 1973; Summers et al., 1976; Summers and Branch, 1984; but see Eberts, 1979)"(LOGAN; MOLOTCH, 1987, p.89)

${ }^{27}$ in LOGAN; MOLOTCH (1987).
} 
É crescente a percepção de que muitos dos problemas urbanos estão ligados à problemática ambiental, com enchentes, poluição, saneamento, etc. Contudo, essas questões costumam ser ambientalmente tratadas de forma isolada, sem que se tenha uma matriz única de compreensão da questão (FERREIRA; FERRARA, 2012).

BERTUCCl et al. (2002) também frisam que quando parte da população não tem condições estruturais básicas para viver num ambiente minimamente sadio, ela é forçada a improvisar sua habitações em locais muitas vezes insalubres, ambientes frágeis e ecologicamente sensíveis (como manguezais, encostas, etc.). Deste modo, o problema da distribuição de renda acaba também sendo um colaborador do problema do déficit habitacional e no percentual de domicílios não atendidos adequadamente por rede de abastecimento de água e de coleta de esgoto. Cabe lembrar que os dados do IBGE mostram que, com exceção do Centro-Oeste do país, boa parte dos municípios, ainda que tenham uma boa rede de coleta de esgoto, não fazem o tratamento adequado do mesmo (figura 2). Além dos prejuízos ambientais, o saneamento inadequado está relacionado a problemas de saúde como: diarréias, febres entéricas, hepatite A, dengue, Febre Amarela, leishmanioses (tegumentar e visceral), filariose linfática, malária, Doença de Chagas, esquistossomose, leptospirose, tracoma, conjuntivites, micoses superficiais, helmintíases e teníases. Estas doenças somaram em 2008 mais de meio milhão de internações nos hospitais públicos do país.
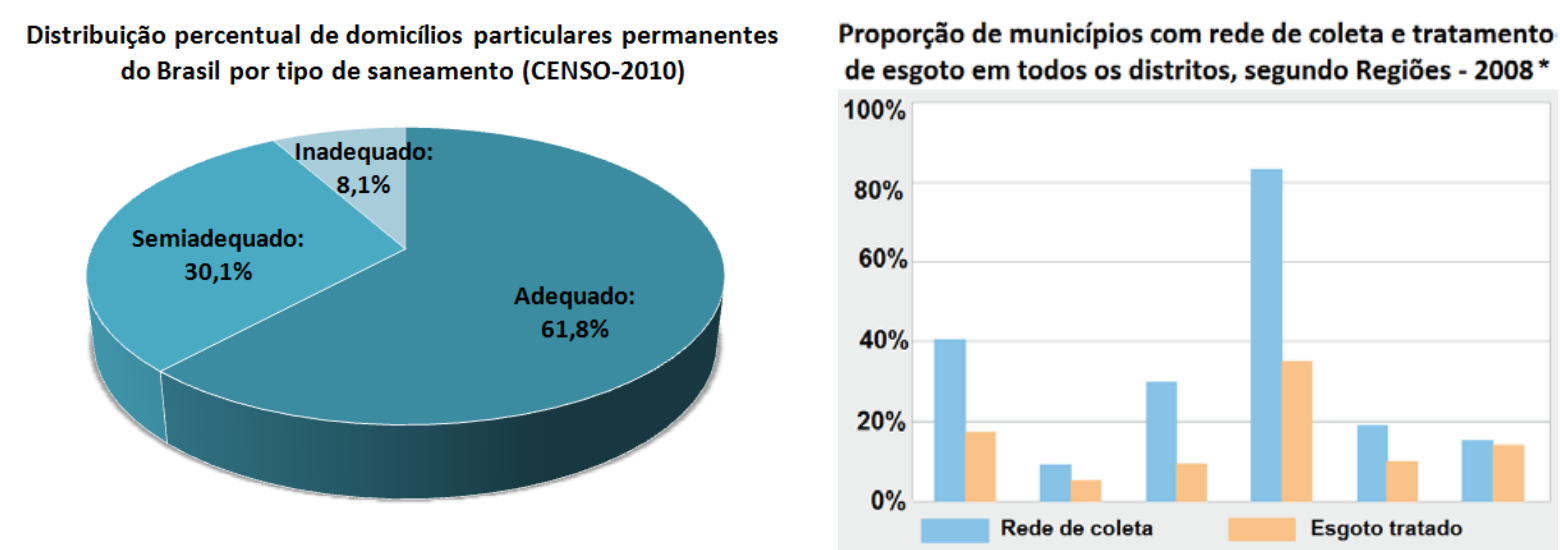

Figura 2 - Fonte: Elaboração própria com base em dados do Instituto Brasileiro de Geografia e Estatística, disponíveis em www.ibge.gov.br

* Nota: Foram contabilizados apenas os dado sem que todos os distritos possuem rede de coleta e tratamento de esgoto.

Ferreira e Ferrara (2012) informam que, historicamente, o processo de crescimento urbano esteve diretamente ligado ao aumento dos impactos ambientais, seja pela industrialização notadamente poluente instalada em territórios contíguos, seja pela 
ocupação humana feita sem os devidos cuidados. Para os autores, as aglomerações urbanas por si só já são impactantes. Embora representem, ao longo da história da humanidade, uma solução mais racional para a convivência de uma população numerosa, elas causam prejuízos ambientais, sobretudo localmente. Entre outros motivos, isso ocorre devido ao grande desflorestamento, à elevada taxa de impermeabilização do solo, ao alto nível de emissões de gases poluentes de forma concentrada, à poluição dos corpos d'água e à contaminação do solo.

Furtado (1974) também critica uma política de desenvolvimento que foque apenas no Produto Interno Bruto (PIB) do país e não na qualidade de vida dos seus habitantes. Chamando o PIB de "vaca sagrada dos economistas"28 o autor questiona:

"Por que ignorar na medição do PIB o custo para a coletividade da destruição dos recursos naturais não renováveis, e o dos solos e florestas (dificilmente renováveis)? Por que ignorar a poluição das águas e a destruição total dos peixes nos rios em que as usinas despejam os seus resíduos?" (FURTADO, 1974, p.116).

Para ele, quando o aumento da taxa de crescimento do PIB é acompanhado de problemas socioambientais (como a baixa do salário real, graves desgastes do meio ambiente, alta do índice de mortalidade infantil, etc.) essa alta econômica é anulada com a baixa social e ambiental, pois significa que os privilégios de uns se deram às custas do sofrimento de outros.

Na sua introdução sobre justiça social, Ferreira e Ferrara (2012) expõem o paradoxo da sustentabilidade urbana dos países que vivem intenso ciclo de crescimento econômico e urbano: “quanto mais as cidades crescem e se 'desenvolvem', nos padrões de urbanização que o mundo adotou desde a revolução industrial, maiores são os impactos ambientais decorrentes” (FERREIRA; FERRARA, 2012, p.1). Na visão desses autores, a ocorrência de problemas ambientais em decorrência dos processos de crescimento econômico com urbanização não é uma peculiaridade brasileira, é um fato em qualquer país. Ocorreu na Europa entre 1960-1990 e ocorre hoje nos chamados países emergentes.

$\mathrm{Na}$ impossibilidade de equilibrar a equação entre a sustentabilidade de um lado e crescimento econômico e urbanização de outro, estes países passaram, nas últimas décadas, a considerar a questão ambiental como fundamental na agenda política, tendo como regra a busca por soluções alternativas que diminuam os impactos ambientais em questões centrais como lixo, saneamento básico, transportes, consumo energético, poluição do ar,

${ }^{28}$ FURTAD0, 1974, p. 116. 
etc. Por isso é que nos anos 1990 definiram conceitos e regras sobre a questão ambiental, promovendo políticas públicas locais e acordos internacionais. Contudo, ainda que desde o início do século XXI não seja mais aceitável tratar da questão dos impactos ambientais urbanos a partir dos mesmos referenciais dos séculos passados, alguns desses países desenvolvidos ainda são líderes em emissões de poluentes e o fazem em nome do constante crescimento econômico acelerado. Assim, os recursos naturais findáveis são explorados de forma exagerada e repartida de forma desigual.

Esse processo de desenvolvimento injusto e insustentável se reflete nas nossas sociedades em todos os aspectos: econômicos, sociais, culturais e políticos. Essa matriz urbana "insustentável", que afeta tanto pobres quanto ricos (ainda que em escalas diferenciadas) é resultante, entre outros, de um modelo de transporte que, historicamente no Brasil, favoreceu o automóvel, contando com obras de engenharia para construção de vias que por vezes justificaram a canalização e tamponamento de rios e córregos, desflorestamento de área nativas, cortes de morros e até aterros marítimos.

Assim, Ferreira e Ferrara (2012) destacam que "a noção de sustentabilidade urbana passa, antes de tudo, pela ideia de sermos capazes de reverter os atuais padrões de urbanização rumo ao estabelecimento de uma nova matriz urbana”. Logo, é necessário buscar reverter o passivo socioambiental herdado da industrialização tardia desenvolvimentista e ser capaz de regular e organizar as urbanizações atuais utilizando parâmetros socialmente mais justos e menos impactantes. Desta forma, o desafio ambiental urbano prioritário é o enfrentamento, com políticas integrada, do passivo ambiental e social já existente e a implantação de medidas eficazes para que esse fatores de injustiças socioambientais não voltem a crescer. Nesse contexto, os autores colocam a importância de uma reforma fundiária e urbana no Brasil.

A busca por "sustentabilidade urbana" poderia ser um instrumento de aglutinação em uma agenda claramente estabelecida, de todas as políticas que, de forma esparsa, tratam da questão, sem que se tenha, entretanto, sua apreensão conjunta. Tal agenda deveria permitir promover o que aqui chamamos de "justiça ambiental” 29, uma definição mais precisa do que a de “sustentabilidade urbana” (FERREIRA; FERRARA, 2012, p.18, grifo dos autores).

Como vimos, para Bresser-Pereira (2012), o "desenvolvimento econômico é parte de um fenômeno histórico maior que é o desenvolvimento sem adjetivos, ou do desenvolvimento sustentável no plano econômico, social e ambiental, ou do

${ }^{29}$ Conforme conceito trabalhado em: ACSELRAD, Henri; HERCULANO, Selene; PÁDUA, José Augusto. Justiça ambiental e cidadania. Rio de Janeiro: Relume Dumará: Fundação Ford, 2004. 
desenvolvimento humano" (BRESSER-PEREIRA, 2012, p.15). Ele acredita que um desenvolvimento (sem adjetivos) implica em mudanças estruturais em toda a sociedade. Sendo assim, Bresser-Pereira aponta que o desenvolvimentismo é uma ideologia e uma estratégia de desenvolvimento econômico na qual, à medida que o setor econômico avança, avançariam também os setores ambientais e sociais.

Nesse contexto, Siscú, Paula e Michel (2007) percebem que há, entre os acadêmicos da Ciência Econômica, um debate acalorado sobre os mecanismos para assegurar uma melhor distribuição da renda e da riqueza. De um lado estão os economistas que acreditam que a qualificação da mão de obra deve ser associada a reformas na legislação trabalhista e a reformas políticas sociais para assim atingir um melhor perfil distributivo de forma eficiente. Do outro lado, estão os economistas que acreditam que taxas elevadas e permanentes do crescimento econômico vão assegurar um progresso no perfil distributivo. Julgando que ambos os lados trazem argumentos importantes ao debate, Siscú, Paula e Michel (2007) defendem o meio termo entre as duas posições citadas, pois:

(...) entende-se que somente o crescimento econômico a taxas elevadas e continuadas pode minorar o problema da desigualdade na economia brasileira. ${ }^{30}$ Mas esta é apenas uma condição necessária porque gera empregos e arrecadação tributária que pode ser utilizada na implementação de programas sociais universalizantes. É condição necessária mas não suficiente porque políticas sociais e educacionais - entendidas como instrumentos para a inclusão econômica formal de segmentos da população deseducados que possuem baixa produtividade no trabalho e que recebem, em consequência, baixos salários - são elementos também centrais no enfrentamento da questão das exageradas desigualdades presentes no país. Todavia, qualificação sem crescimento produzirá, por exemplo, uma gama de trabalhadores bem-educados subempregados ou desempregados (Siscú, Paula e Michel, 2007, p.17).

Ainda que no seu artigo estes autores não desenvolvam muito essa ideia, ela nos parece razoável. Afinal, um processo de crescimento e modernização do setor industrial traz benefícios econômicos reais para uma nação, mas de fato, isoladamente não são suficientes para gerar benefícios sociais. Ferreira e Ferrara (2012) também colocam que na atual conjuntura de crescimento econômico que o país vive, a aceleração da urbanização é inexorável. Entretanto, embora a instalação de novas indústrias possa efetivamente gerar empregos e divisas para o país, historicamente, o "modus operandi" do processo de

${ }^{30}$ Segundo Siscú, Paula e Michel (2007) ao analisar o crescimento do produto e de renda no Brasil entre 1960 e 1980, Salm (2005, p. 200), conclui: "não fosse o crescimento proporcionado pelos investimentos que introduziram os estágios mais avançados da indústria na época, o desemprego e a informalidade já teriam eclodido bem antes da crise da dívida. Quando examinamos os números brasileiros do período, impressiona o dinamismo da geração de empregos pelos novos setores”. 
industrialização tem induzido a passivos socioambientais. Desta forma, são necessárias algumas alterações no modelo neodesenvolvimentista para que este processo não acarrete no agravamento dos problemas já existentes e possa, de fato, ter um saldo positivo nos aspectos socioambientais.

Tanto Furtado (1974), como Ferreira e Ferrara (2012) e Bertucci et al. (2002) concordam que o debate acerca dos problemas socioambientais gerados pelo crescimento econômico é bastante complexo e não há solução milagrosa para esta questão. Contudo, todos eles, de alguma forma, introduzem a ideia que o crescimento econômico acelerado, nos moldes do (neo)desenvolvimentismo e calcado em desigualdades sociais, econômicas e culturais, acaba gerando conflitos e problemas socioambientais, que poderiam ser, ao menos mitigados com medidas estatais que precedessem (ou ao menos acompanhassem) esses processos de industrialização.

Desta forma, com base no autores aqui já citados, iremos destacar algumas dessas medidas fundamentais, pois elas nos auxiliarão na aplicação desse debate no nosso estudo de caso, o Arco Metropolitano do Rio de Janeiro (AMRJ). As medidas são:

- a inclusão do debate da justiça socioambiental na política pública de todos os setores e em todas as esferas de governo;

- a promoção significativa de investimentos públicos destinados à habitação de interesse social (HIS), sobretudo para pessoas com faixa de renda entre zero e três salários mínimos, visando à mitigação do déficit habitacional existente. Cabe ressaltar que devem ser utilizadas estratégias diferenciadas de acordo com as especificidades locais e os diferentes tipos de déficit (habitação precária, coabitação familiar, ônus excessivo com aluguel e adensamento excessivo);

- a implantação de habitação de interesse social (HIS) voltada para as novas áreas em expansão, sobretudo aquelas que possuem investimento financeiro do Estado em empreendimentos com potencial gerador de novas oportunidades de empregos;

- urbanização das áreas referidas acima, incluindo infraestrutura básica (esgotamento sanitário, abastecimento de água, fornecimento de energia elétrica e iluminação pública), sistema de transporte público e também equipamentos de saúde, educação e lazer, visando a universalização da oferta de saneamento ambiental adequado (não só coleta, e sim tratamento completo), principalmente 
a todas as edificações (residenciais, comerciais ou industriais) que já possuem conexão com rede de abastecimento de água;

- a mudança da matriz de transporte urbano para o transporte coletivo de massa, em detrimento do automóvel de uso individual;

- a promoção de investimentos públicos que atraiam novos empreendimentos industriais em locais em que há excedente de mão de obra disponível compatível com os empregos que serão gerados e oferta de cursos profissionalizantes para capacitação da população que irá assumir os novos postos de trabalho;

- a reforma da legislação trabalhista para que esta atenda de forma satisfatória a relação trabalhador-empresa, de forma a garantir justas condições de trabalho e remuneração; e

- a atualização de medidas de aprovação, fiscalização e compensação ambiental das obras e do funcionamento de novas empresas com potencial poluidor, visando principalmente ampliar a participação, buscando evitar futuros problemas socioambientais e sobretudo malefícios às populações atingidas pelo empreendimento. 
Capítulo 2 


\section{Capítulo 2:}

\section{O Arco Metropolitano do Rio de Janeiro}

\subsection{Contexto político - econômico}

0 Arco Metropolitano do Rio de Janeiro (AMRJ) foi idealizado inicialmente pelo governo militar, em 1974. Tal projeto foi criado no âmbito do plano rodoviário estadual, pouco antes da criação da FUNDREM (Fundação para o Desenvolvimento da Região Metropolitana do Rio de Janeiro). Contudo, por mais de três décadas o projeto só ficou no papel.

Entre 1980 e 1995 a economia fluminense vivenciou uma crise econômica, social e político-institucional. Dentre as principais manifestações desta crise estão: a decadência e a falta de competitividade da indústria fluminense, sobretudo se comparada com o estado de São Paulo; a efetiva redução do conjunto dos gastos públicos federais no Estado; e o agravamento dos conflitos de natureza federativa, em especial entre as instâncias federal e estadual (NATAL, 2004).

Segundo Natal (2004), durante o século XX, o estado de São Paulo estava na vanguarda da industrialização capitalista brasileira. Enquanto isso, a cidade do Rio de Janeiro estava voltada para as suas funções de capital política do país. Havia então, uma divisão inter-regional do trabalho, sendo São Paulo a "capital financeira" do país.

Por diversas razões (como solo, transporte, mão de obra escrava empregada, frágil mercado interno e internacional, etc.) os municípios do antigo estado do Rio de Janeiro, cuja capital era a cidade de Niterói, não tiveram fôlego para competir com a industrialização da Região Metropolitana de São Paulo (RMSP).

Com a transferência da capital para Brasília, ocorre a fusão do estado da Guanabara com o antigo estado do Rio de Janeiro. Todo o novo estado do Rio de Janeiro entra em crise. Sendo São Paulo o polo industrial do país, a cidade do Rio de Janeiro tinha uma economia frágil, voltada sobretudo para seu mercado interno e extremamente dependente das rendas oriundas do governo federal, como transferências constitucionais, salários para seu enorme contingente de funcionários públicos, etc.. Para Natal (2004), a crise também se 
deve a uma incapacidade das elites empresariais, sobretudo da indústria naval, de buscar soluções para mitigar a situação.

[...]parcela dessa crise deve ser tributada na conta das elites empresariais, notadamente as comerciais, financeira e da indústria naval, sediadas no município do Rio de Janeiro, que sempre firmaram sua hegemonia no debate sobre os rumos da economia e sociedade fluminense, e, nesse sentido, operaram para que a degradação econômica e a crescente perda de posição diante da economia de São Paulo fossem sendo ampliadas ao longo do período examinado. (NATAL, 2004, p.75).

Em meados dos anos 1990 o país vive o lançamento do Plano Real, que traz a derrubada da inflação e subsequentemente, por um par de anos, o crescimento econômico e aumento das ofertas de emprego. Na capital fluminense ascende ao poder César Maia, cuja gestão tinha o apoio do arquiteto e urbanista Luiz Paulo Conde, e inicia uma série de intervenções urbanísticas. Se por um lado tais intervenções mudavam a paisagem da cidade degradada, por outro, passava a ideia de que essas obras "confeririam ao município do Rio de Janeiro maior capacidade de ingresso nas grandes correntes econômicas de um mundo supostamente globalizado" (NATAL, 2004, p.76).

Havia, assim, um anseio em acompanhar São Paulo, propagandeado pelo "mito da cidade global" experimentado pela capital paulista, conforme colocado por Ferreira (2007). Com esse intuito, foi elaborado o Plano Estratégico da Cidade do Rio de Janeiro, que recomendou a adequação à nova ordem internacional. Em decorrência disso, coube ao poder local a tarefa de tomar ações para que o espaço da cidade se tornasse mais atrativo para os grandes capitais, particularmente os estrangeiros (NATAL, 2004).

Na segunda metade da década de 1990, ocorre um significativo aumento da produção de petróleo e gás natural e também dos investimentos privados. Muitos destes aportes foram financiados com recursos públicos, sobretudo pelo Banco Nacional de Desenvolvimento Econômico e Social (BNDES).

Para Natal (2004), esses são os maiores fatores para a inflexão econômica positiva do estado do Rio de Janeiro ocorrida no final do século XX. No gráfico abaixo (figura 3), podemos conferir que a produção de petróleo cresceu $87 \%$ nos cinco últimos anos do milênio e a de gás natural aumentou mais de 73\% nesse mesmo período. 


\begin{tabular}{|c|c|c|c|c|c|c|}
\hline \multirow{2}{*}{ Anos } & \multicolumn{3}{|c|}{ Produção de Petróleo $\left(10^{3} \mathrm{~m}^{3}\right)$} & \multicolumn{3}{|c|}{ Produção de Gás Natural $\left(10^{6} \mathrm{~m}^{3}\right)$} \\
\hline & Brasil & ERJ & ERJ/Brasil & Brasil & ERJ & ERJ/Brasil \\
\hline 1995 & 40.216 & 27.126 & 67,5 & 8.107 & 3.165 & 39,0 \\
\hline 1996 & 45.606 & 31.294 & 68,6 & 9.214 & 3.577 & 38,8 \\
\hline 1997 & 48.832 & 34.662 & 71,0 & 9.865 & 3.876 & 39,3 \\
\hline 1998 & 56.587 & 41.647 & 73,6 & 10.833 & 4.544 & 41,9 \\
\hline 1999 & 63.921 & 49.110 & 76,8 & 11.898 & 5.528 & 46,5 \\
\hline 2000 & 71.844 & 57.037 & 79,4 & 13.328 & 5.721 & 42,9 \\
\hline 2001 & 75.219 & 60.489 & 80,4 & 14.045 & 5.968 & 42,5 \\
\hline Variação \% (2001/1995) & 87,0 & 123,0 & - & 73,3 & 88,6 & - \\
\hline
\end{tabular}

Figura 3 - Evolução da produção de petróleo e gás natural do Estado do Rio de Janeiro (1995-2000). Fonte de dados: DIEESE (2002, p. 148) in Natal (2004).

Em poucos anos o estado do Rio de Janeiro passa a ser responsável por cerca de $80 \%$ da produção nacional de petróleo. Com essa marca alcançada assim que assume o cargo, em 2003, a governadora Rosinha Matheus inicia um movimento pela construção de uma refinaria de petróleo na Região Norte Fluminense intitulado "A Refinaria é Nossa”. Tal movimento ganha o apoio da Federação das Indústrias do Estado do Rio de Janeiro (FIRJAN) e faz menção à frase "o petróleo é nosso", da época do presidente Getúlio Vargas.

A Petrobras decide, então, instalar no estado a sua nova refinaria, o Complexo Petroquímico no estado do Rio de Janeiro (COMPERJ). Em 2006 é escolhida uma área de quarenta e cinco quilômetros quadrados no município de ltaguaí para abrigar o COMPERJ e um terreno no município de São Gonçalo para sediar o Centro de Inteligência do primeiro. É nesse cenário que aquele antigo projeto de rodovia, o AMRJ, é "ressuscitado", ganhando uma dimensão econômica completamente nova.

Deste modo, em 2006, o COMPERJ passa a ser visto pelo poder público como um dos pontos centrais de uma nova estratégia neodesenvolvimentista para a Região Metropolitana do Rio de Janeiro (RMRJ). Em 2007, o projeto do Arco Rodoviário é incluído no Programa de Aceleração do Crescimento (PAC) do governo federal.

Apesar de não se configurar como um plano econômico e sim como um conjunto de projetos, o PAC deixa claro seu viés neodesenvolvimentista ao focar em projetos de infraestrutura, considerados básicos para o crescimento do comércio e da indústria. Ao analisar os investimentos do PAC no setor industrial da RMRJ (figura 4), torna-se evidente que o AMRJ é um projeto de infraestrutura que pretende dar suporte aos empreendimentos 
industriais do PAC para esta região, já que o Arco interliga todos esses grandes empreendimentos.

\begin{tabular}{|c|c|c|c|c|}
\hline EMPREENDIMENTO & LOCAL & $\begin{array}{c}\text { INVESTIMENTO } \\
\text { PREVISTO } \\
\text { (em US\$) }\end{array}$ & DAS OBRAS & DA OPERAÇÃO \\
\cline { 5 - 6 } & & PREVISÃO DE INÍCIO \\
\hline $\begin{array}{c}\text { COMPLEXO PETROQUÍMICO DO RIO DE } \\
\text { JANEIRO (COMPERJ) }\end{array}$ & $\begin{array}{c}\text { ITABORAÍ / SÃO } \\
\text { GONÇALO }\end{array}$ & 8,4 bilhões & 2007 & 2012 \\
\hline $\begin{array}{c}\text { COMPANHIA SIDERÚRGICA DO } \\
\text { ATLÂNTICO (CSA) }\end{array}$ & SANTA CRUZ - RJ & 3,4 bilhões & 2007 & 2009 \\
\hline SIDERURGIA NACIONAL (CSN) & ITAGUAÍ & 3,5 bilhões & $2007-2008$ & 2009 \\
\hline PORTO DE ITAGUAÍ & ITAGUAÍ & 700 milhões & 2007 & --- \\
\hline
\end{tabular}

Figura 4 - Investimentos no setor industrial previstos pelo PAC na RMRJ. Fonte: elaboração própria com base em RIO DE JANEIRO (2011).

Além de atender ao COMPERJ, o Arco ainda potencializa o fluxo viário para outros empreendimentos, conforme mostrado no mapa a seguir (figura 5). Alguns destes empreendimentos também são da Petrobras, como por exemplo, a Refinaria de Duque de Caxias (REDUC). Entre outros empreendimentos beneficiados pelo Arco estão: o distrito industrial da Bayer, em Belford Roxo; o complexo gás-químico da Rio Polímeros, em Duque de Caxias; o complexo industrial de Santa Cruz, no Rio de Janeiro; e a usina siderúrgica operada pelo Thyssen-Krupp (conhecida como TKCSA), na baía de Sepetiba.

Em uma matéria da revista Techne ${ }^{31}$, o subsecretário de urbanismo da Secretaria Estadual de Obras, Vicente Loureiro, apontou que em um trecho da BR-493, há um paralelismo com o ramal ferroviário de cargas da MRS Logística. Essa é uma grande vantagem que as empresas teriam ao se instalarem ao longo do Arco, na periferia da região metropolitana.

0 estudo "Avaliação dos Impactos Logísticos e Socioeconômicos da Implantação do Arco Metropolitano do Rio de Janeiro" ${ }^{2}$ aponta que o Arco irá reduzir os custos de transporte de mercadorias entre o Porto de ltaguaí e sete estados brasileiros, com porcentuais que variam de $2,5 \%$ a $20 \%$. Sendo assim, espera-se um aumento nos lucros das indústrias da região principalmente por causa da economia direta nos custos com transporte. 0 mesmo estudo aponta ainda que o custo da obra na economia brasileira será de $\mathrm{R}$ 1,8 bilhão, concentrado basicamente no setor de construção civil responsável por $64,1 \%$ deste total.

\footnotetext{
${ }^{31}$ Disponivel em: http://www.revistatechne.com.br/engenharia-civil/126/imprime61997.asp. Último acesso em 03 de março de 2012.

${ }^{32}$ Encomendado pelo Sistema FIRJAN e pelo SEBRAE-RJ ao Centro de Estudos em Logística da COPPEAD/UFRJ e à Tendências Consultoria.
} 


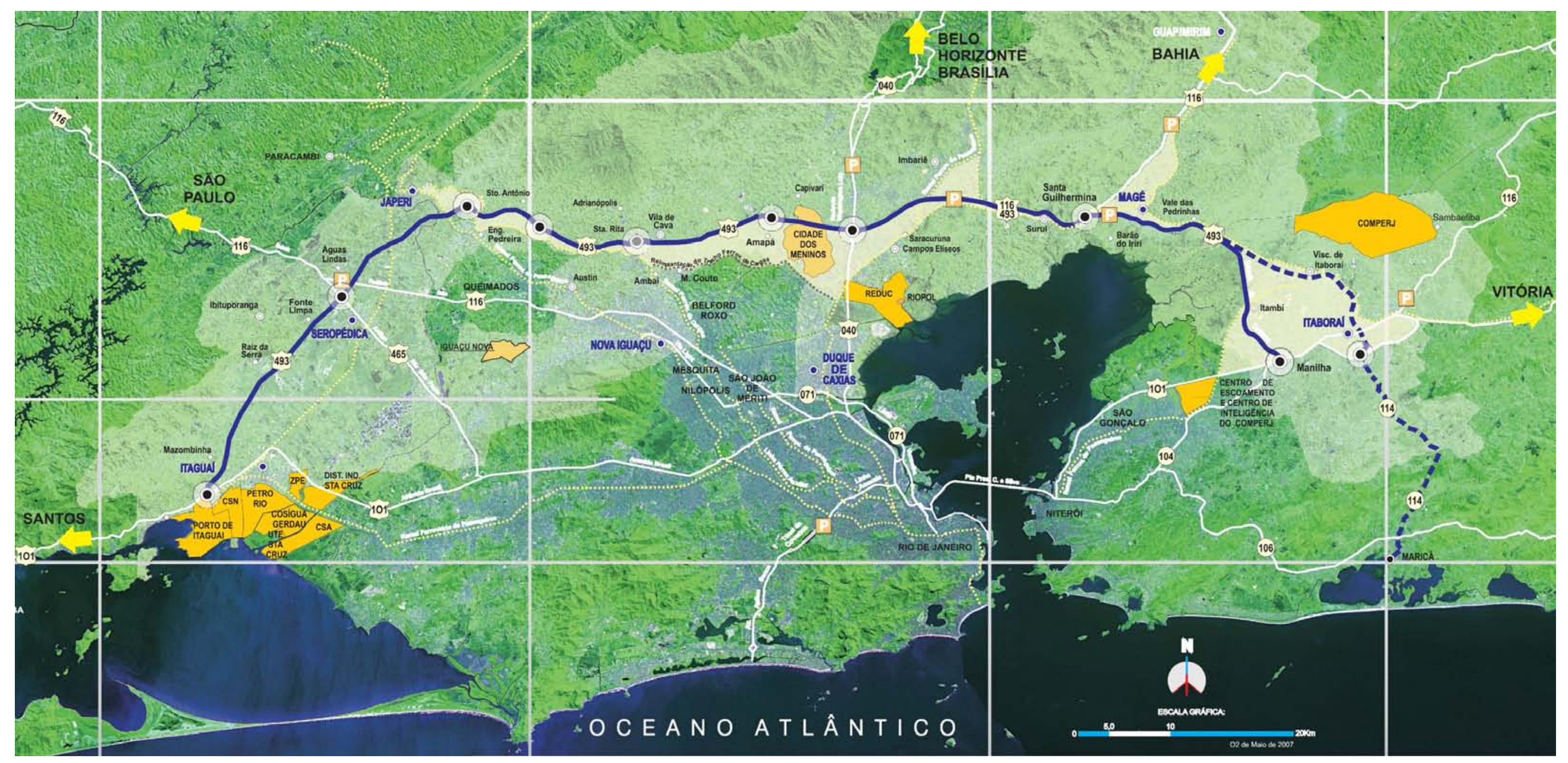

Figura 5 - Principais rodovias e empreendimentos atendidos pelo AMRJ. Fonte: PDAM (2011) 


\subsection{0 empreendimento}

0 AMRJ é o maior empreendimento público rodoviário do estado fluminense das últimas décadas, tendo cerca de $140 \mathrm{~km}$ de extensão. Na sua área de abrangência estão vinte e um municípios, dos quais, oito são interceptados diretamente pelas obras do Arco, são eles: Itaguaí, Seropédica, Japeri, Nova Iguaçu, Duque de Caxias, Magé, Guapimirim e Itaboraí. Seu traçado atual interligará as cinco principais rodovias que atravessam a Região Metropolitana do Rio de Janeiro (RMRJ): a rodovia Washington Luís (BR-040), a rodovia Presidente Dutra (BR-116), a antiga estrada Rio-São Paulo (BR-465), a Rodovia Rio-Santos (BR-101 sul) e a Rodovia Rio-Vitória (BR-101 norte).

\subsubsection{Os objetivos diretos}

Conforme será aqui exposto no item sobre o contexto político-econômico, o Arco se constitui como uma obra de infraestrutura de base para a construção de um projeto econômico-industrial muito mais amplo do que a construção do eixo rodoviário em si. Não por acaso, inicialmente o seu prazo de início de funcionamento coincidiria com o início das operações do COMPERJ. As principais fontes governamentais de informação sobre o AMRJ apontam que objetivos centrais desta rodovia são:

- fornecer acesso expresso ao Porto de ltaguaí e ao futuro polo petroquímico da cidade de ltaboraí, tendo papel fundamental por facilitar a logística de produção do COMPERJ (PDAM, 2011; RIMA, 2007);

- atender ao tráfego de longa distância oriundo das regiões SUL/SUDESTE em direção às regiões NORTE/NORDESTE do país (RIMA, 2007);

- conectar as principais rodovias federais da Região Metropolitana do Rio de Janeiro, a saber: BR-040 (liga o Rio de Janeiro a Belo Horizonte), BR- 465 (antiga Rio- São Paulo), BR-116 (corta o país de norte a sul, ligando o Rio de Janeiro a São Paulo, Teresópolis, Minas Gerais, Bahia, etc.) e BR-101 (corta o país de norte a sul beirando o litoral, liga o Rio de Janeiro a Ubatuba, Vitória, etc.) (PDAM, 2011; RIMA, 2007);

- evitar a entrada desnecessária de veículos que estejam somente de passagem pela cidade do Rio de Janeiro, diminuindo assim os engarrafamentos na 
Ponte Rio-Niterói (BR-101), na Avenida Brasil e na BR-101 (entre Manilha e Ponte) (PDAM, 2011; RIMA, 2007).

- aumentar os níveis de acessibilidade dos municípios próximos ao Arco e que concentram grande contingente populacional (PDAM, 2011);

- viabilizar a implantação de terminais logísticos, com redução dos tempos de viagem e custos de transportes, bem como a distribuição destas cargas para os mercados consumidores (RIMA, 2007).

\subsubsection{0 projeto do Arco}

Conforme mostrado no mapa a seguir (figura 6), a extensão total do Arco se divide em quatro segmentos, cada um em diferentes estágios de implantação:

Segmento A - Tem aproximadamente $25 \mathrm{~km}$ e corta os municípios de Itaboraí, Guapimirim e Magé. É um trecho da BR-493 entre Manilha, no município de ltaboraí, e Santa Guilhermina, no município de Magé, que sofrerá obras de duplicação sob a responsabilidade do governo federal. Com obras iniciadas apenas em agosto de 2014, a conclusão está prevista para julho de 2017.

Segmento B - Tem aproximadamente $22 \mathrm{~km}$ e corresponde ao acesso ao Porto de Itaguaí (a partir do segmento C) e à duplicação da pista de trecho da BR-101 entre a localidade de Itacuruçá, no município de Mangaratiba, e o final da Avenida Brasil, em Santa Cruz, que fica na Zona Oeste do municipio do Rio de Janeiro. Ambos os trechos eram de responsabilidade do governo federal e foram executados pelo Departamento Nacional de Infraestrutura em Transportes (DNIT).

Segmento C - Corresponde à construção de $72 \mathrm{~km}$ de via sem pista dupla, que faz a ligação entre as rodovias Rio-Santos (BR-101/SUL) e a rodovia Washington Luís (BR-040) que liga o Rio de Janeiro e Juiz de Fora ao interior de Minas Gerais. Este segmento corta cinco municípios da RMRJ: Nova lguaçu, Duque de Caxias, Japeri, Seropédica e Itaguaí. A responsabilidade pela obra era do governo estadual. Este trecho foi inaugurado em meados de 2014, após sete anos de execução das obras.

Segmento D - Segmento com cerca de $20 \mathrm{~km}$ de extensão, correspondendo a trecho da rodovia Rio-Teresópolis (BR-493) entre Santa Guilhermina, no município de Magé, e o entroncamento com a rodovia Washington Luís (BR-040), no município de Duque de 
Caxias. Este segmento não sofreu obras, dado que já estava duplicado e concedido à empresa $\mathrm{CRT}^{33}$, que administra a via e cobra pedágio.

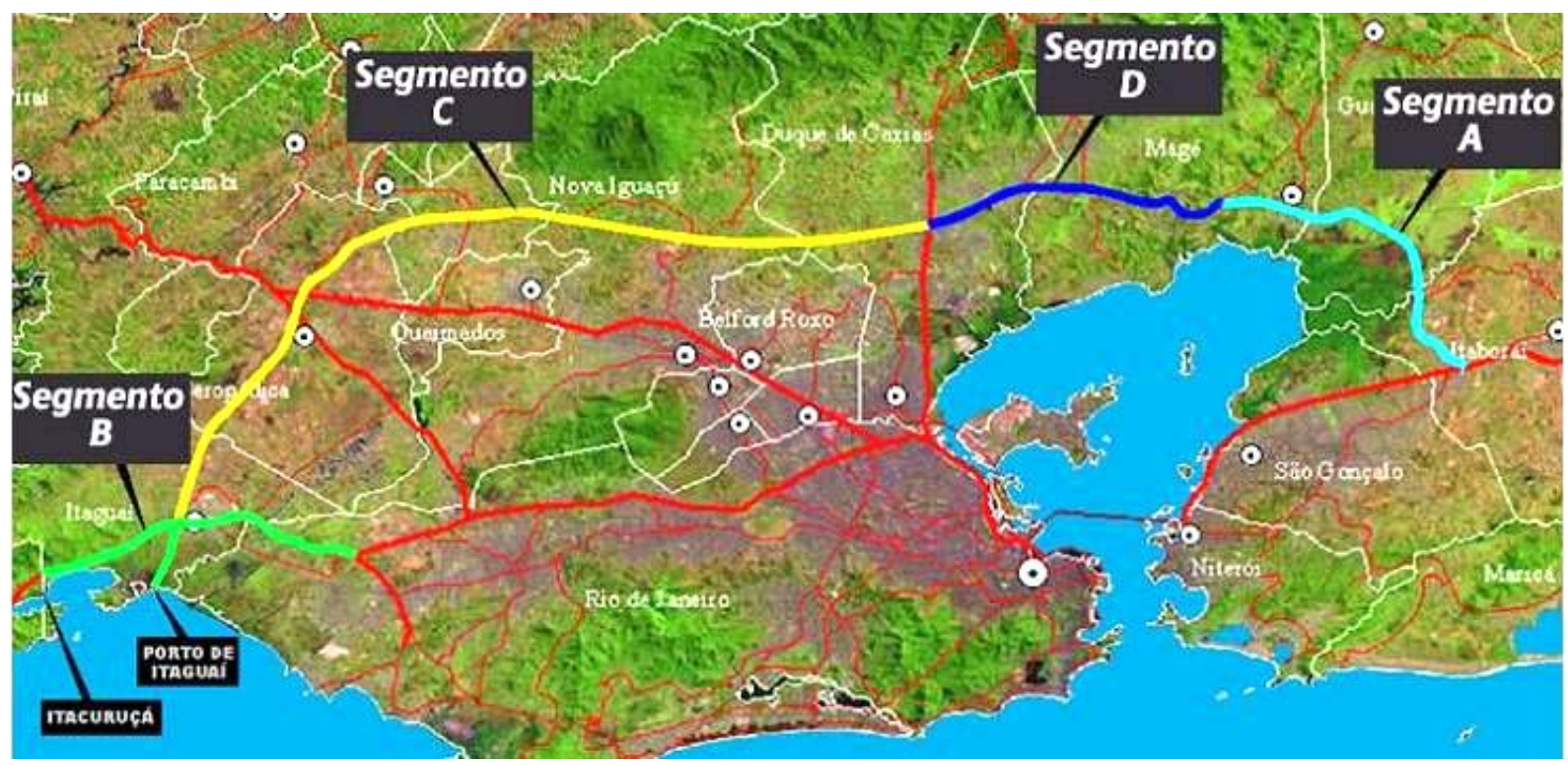

Figura 6 - Mapa do AMRJ e sua divisão por segmentos. Fonte: RIMA (2007).

No Segmento C as tipologias viárias adotadas pelo projeto do AMRJ propõem que a rodovia seja consideravelmente larga em todos os trechos, com seções transversais de cinquenta e cinco ou de cem metros. É uma rodovia não bloqueada, em pista dupla, com acessos controlados. Conforme mostrado nas seções a seguir (figura 7), o Segmento C apresenta a construção de ruas laterais com calçada ou faixa lateral destinada à implantação futura de ruas e calçadas de atendimento às propriedades lindeiras e vias locais. 0 projeto também conta com agulhas de acesso de entrada e saída às pistas centrais em locais específicos, fazendo grandes conexões nos seguintes locais:

- continuação da BR101 em ltaguaí (ligações para a Região Norte e Sul do país);

- trevo de interseção na BR 465 (em Seropédica);

- trevo de interseção na BR116 (Rodovia Presidente Dutra, ligação Rio/São Paulo);

- acesso à Estrada Adrianópolis (em Nova lguaçu);

- acesso à RJ 125 (na estrada que liga Japeri-Miguel Pereira, em Seropédica);

- acesso à RJ 093 (Estrada dos Coqueiros, em Japeri);

- acesso à BR 085 / RJ 115 (Estrada de Xerém, em Duque de Caxias);

\footnotetext{
${ }^{33} \mathrm{~A}$ empresa CRT (Concessionário Rio-Teresópolis) é formada pelas empresas: Construtora OAS, ChristianiNielsen Engenharia S/A, Construtora Queiroz Galvão S/A e EIT - Empresa Industrial Técnica S/A.
} 
- trevo de interseção na BR 040 (ligação para o estado de Minas e para o Planalto Central);

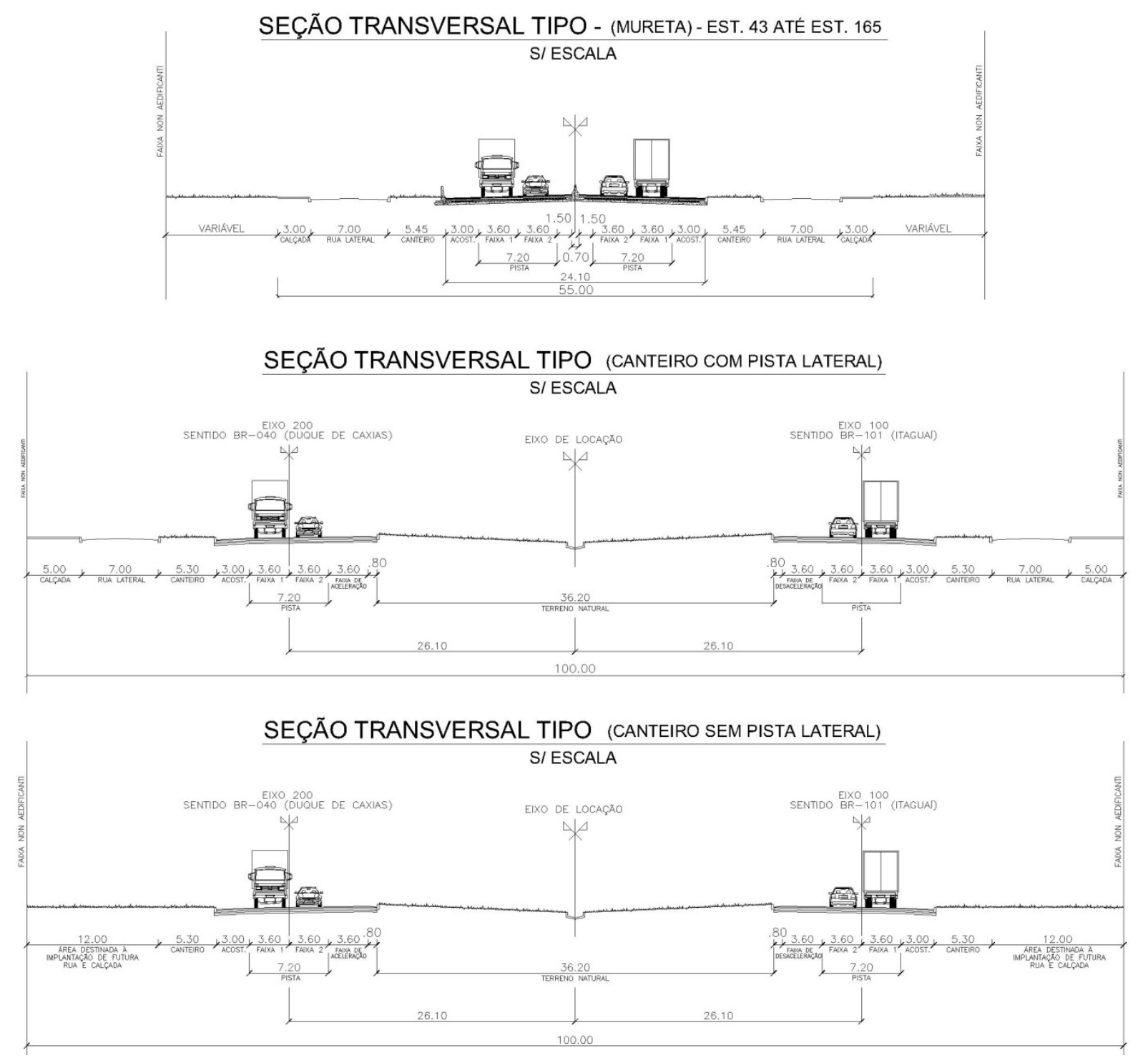

Figura 7 - Seções transversais do AMRJ. Fonte: DER-RJ (2007).

Cabe lembrar que, ainda que o projeto do Arco tenha previsto apenas esses acessos controlados, muitos outros acessos já estão sendo construídos, ainda que informalmente. Uma análise das imagens de satélite do segmento $C$ do Arco mostram exemplos de novos acesso à rodovia que surgiram em apenas seis meses de funcionamento da nova via. 

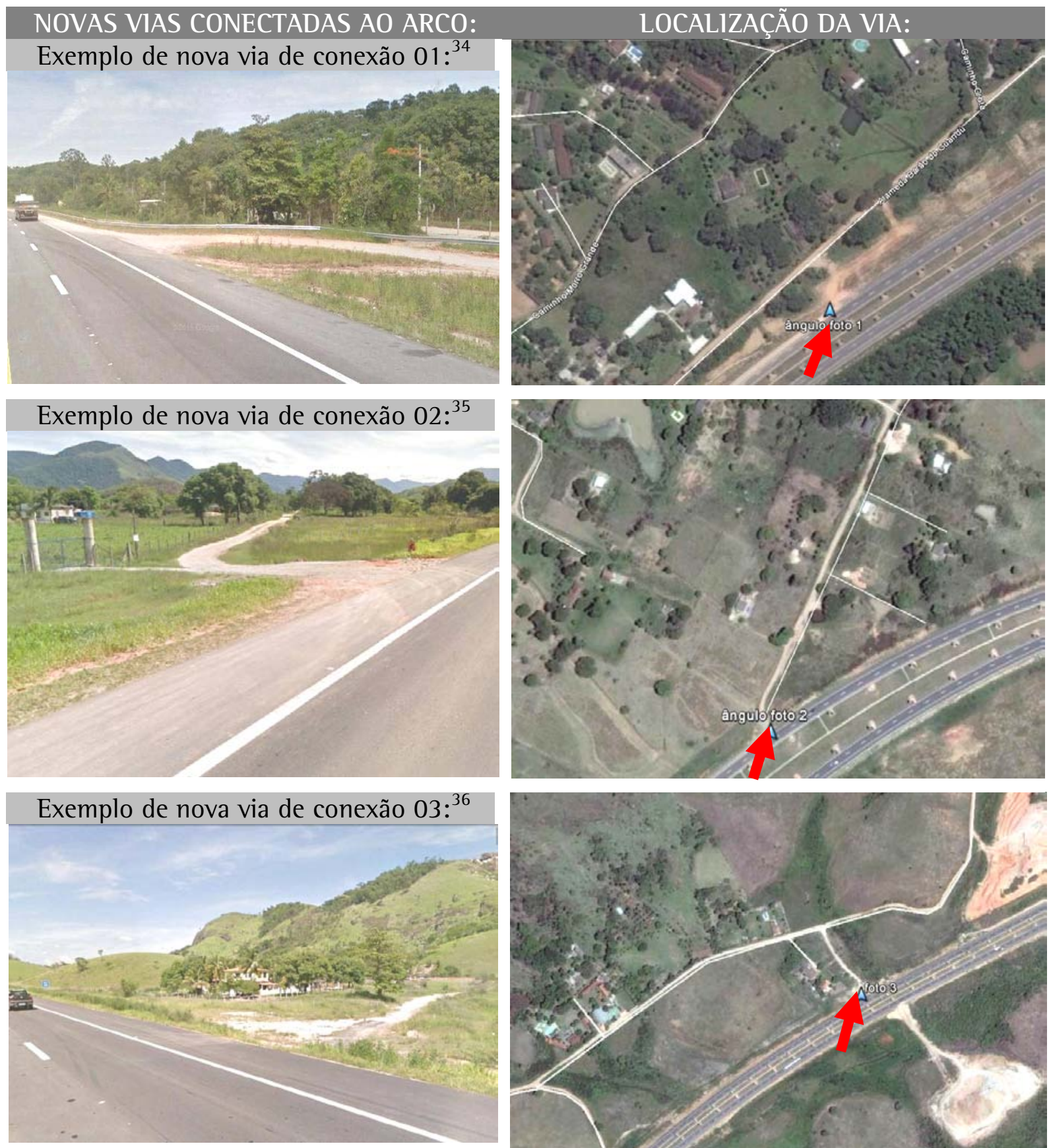

Figura 8 - Novos acessos ao Arco Metropolitano. Fonte: Goggle Street view, imagens de dezembro de 2014.

Após o Arco ser inaugurado, a Câmara Metropolitana de Integração Governamental, vinculada ao governo do estado, juntamente com a Federação das Empresas de Transportes de Passageiros do Estado do Rio de Janeiro (FETRANSPOR) divulgou que serão construídos

\footnotetext{
${ }^{34}$ Entre a estrada Cambota e a estrada São Bernadino, no município de Nova lguaçu, próximo da divisa com Duque de Caxias. Latitude: $22^{\circ} 40^{\prime} 37.65^{\prime}$ S Longitude: $43^{\circ} 24^{\prime} 2.02^{\prime} 0$

${ }^{35}$ Em Seropédica, próximo a divisa com no município de Japeri e ao Rio Guandu. Latitude: 22³9’58.69”S Longitude: $43^{\circ} 38$ '27.54”0

${ }^{36}$ No município de Seropédica, próximo ao Rio Guandu. Latitude: $22^{\circ} 40 ’ 31.53$ ”S Longitude: 43³9’28.47”0
} 
mais dez BRTs ${ }^{37}$ até 2018 na RMRJ, um deles passando pelo Arco Metropolitano. Até então, nenhum documento oficial do Arco previa uma via exclusiva para BRT. (RIBEIRO, 2014)

\subsection{Contexto institucional}

A partir da leitura e análise dos Planos Diretores (PD) dos municípios envolvidos foi possível constatar que em quase todos os casos em que o AMRJ era mencionado, ele era visto como uma potencialidade para o desenvolvimento econômico municipal. De maneira geral, as administrações municipais tendem a adotar uma postura de incentivo às obras do AMRJ, seja apresentando claramente apoio, de forma a viabilizar sua construção, seja adotando uma postura omissa, não colocando condicionantes para a ocupação no entorno do AMRJ (CARDOSO E ARAÚJO, 2012).

Tal omissão pode ter ocorrido por falta de informações sobre o real projeto do AMRJ no momento em que o Plano Diretor estava sendo escrito, ${ }^{38}$ ou de forma intencional, isto é, criando um campo favorável sem maiores definições, logo, sem obstáculos para a fácil implantação das decisões que o PDAM pudesse vir a estabelecer. Notamos assim que a arbitrária aplicação das normas urbanas, comum no Brasil conforme Maricato (2002), no caso do Arco, ocorre desde a sua origem. Ainda na etapa de elaboração de algumas leis, foram deixadas lacunas intencionais, para que estas lacunas pudessem, futuramente, viabilizar a manobra das normas urbanas. Além dessas lacunas, também foi identificada uma situação em que o Plano foi alterado um ano após sua conclusão para se ajustar ao AMRJ.

Pudemos também identificar alguns pontos em que o PDAM entra em contradição com os Planos Diretores municipais. Ainda que, em tese, os instrumentos públicos de planejamento, como Planos Diretores e Leis Orgânicas, tenham como funcionalidade a orientação das ações dos gestores públicos no território, os documentos analisados neste estudo de caso muitas vezes não se colocam dessa forma no que diz respeito à rodovia em questão.

37 BRT vem da sigla em inglês "bus rapid transit" que significa Transporte Rápido por Ônibus. No Rio de Janeiro, são ônibus articulados que trafegam em corredores exclusivos.

${ }^{38}$ Este é o caso do Plano Diretor de Guapimirim, escrito em 2003, antes do anúncio da instalação tanto do COMPERJ quanto do Polo Gás-Químico de Duque de Caxias. 


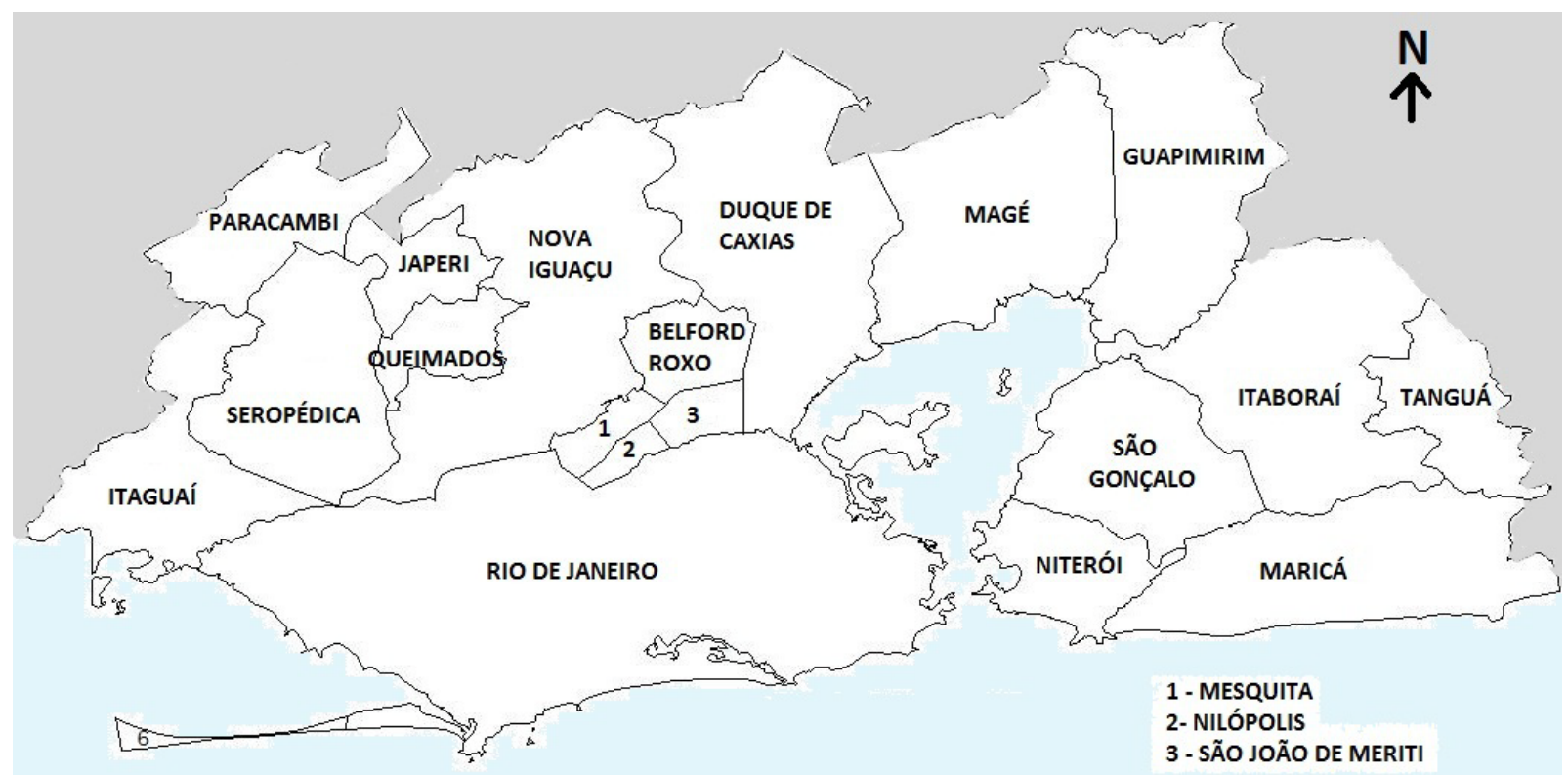

Figura 9 - Municípios da Região Metropolitana do Rio de Janeiro. Fonte: Elaboração própria com base em mapas do Instituto Brasileiro de Geografia Estatística (IBGE).

\subsubsection{Planejamento de incongruências}

A grande maioria dos pontos contraditórios entre o PDAM e os Instrumentos Públicos de Planejamento dos municípios cortados pelo Arco diz respeito às diferenças no zoneamento. O PDAM é bem vago quanto ao zoneamento de uso e ocupação do solo, delimitando somente alguns tipos de uso, a saber: "Conservação", "Proteção", "Uso Múltiplo", "Restauração", "Vazios Urbanos" e "Urbano", sem definir exatamente o que é pensado e proposto para cada um desses usos. Por trabalhar em frações menores e escalas mais aproximadas, em geral, os zoneamentos dos Planos Diretores dos municípios cortados pelo Arco deliberam os usos com frações melhor delimitadas do que o do PDAM.

Em diversos momentos, as determinações do PDAM não são compatíveis com os usos propostos pelos Planos Diretores dos municípios. As incompatibilidades também se dão pelo fato de que, muitas vezes, os Planos ou não citam ou não demarcam o Arco nos seus textos e nos seus mapas. Conforme veremos a seguir, ao analisarmos concomitantemente os textos e mapas dos planos municipais e do PDAM, encontramos várias contradições entre estes documentos. 

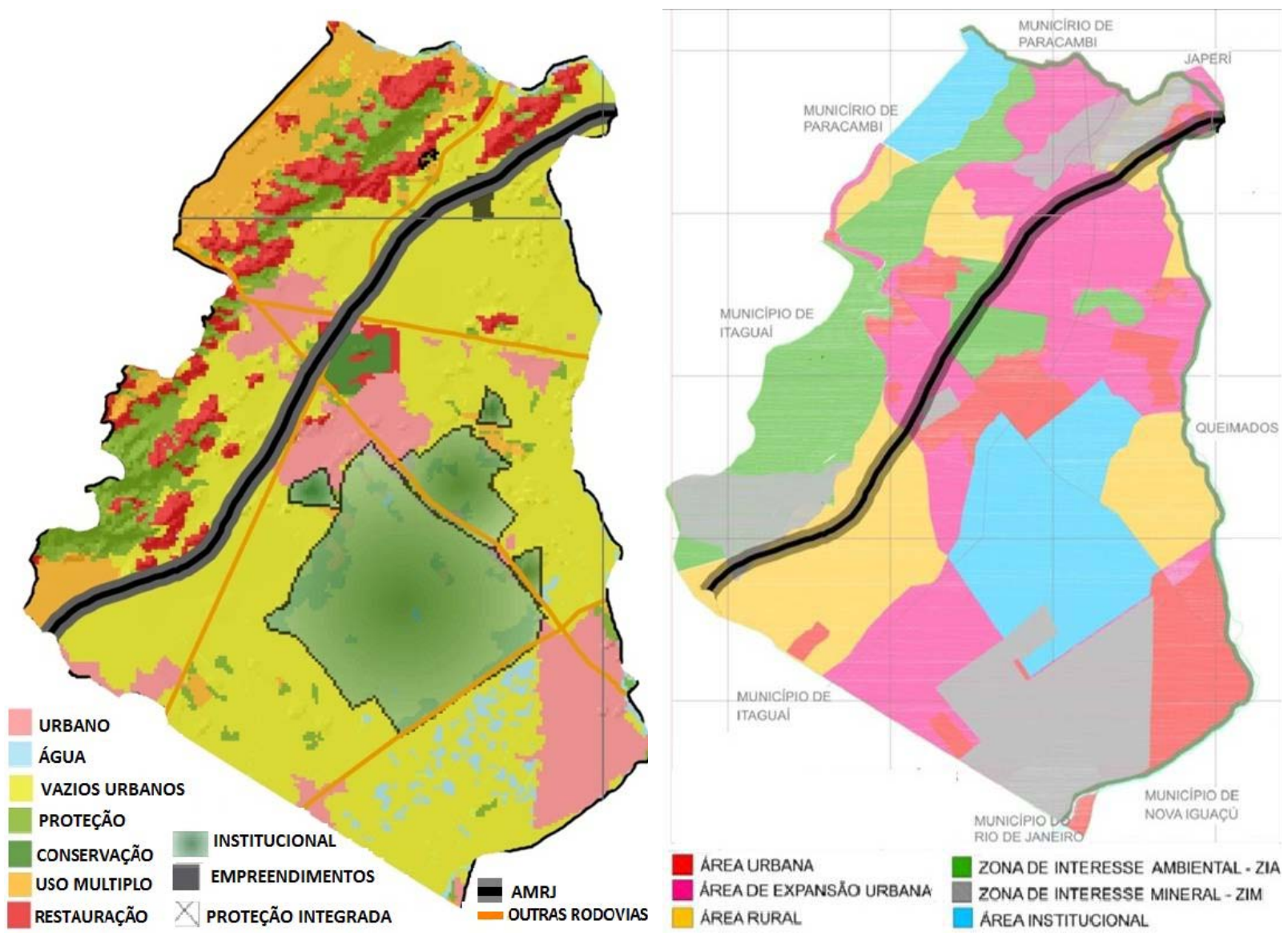

Figura 10 - Diferença entre zoneamento do PDAM (à esquerda) e do PD de Seropédica (à direita).

Fonte: Elaboração própria, com dados do Plano diretor de Seropédica (2006) e do PDAM (2011).

Nos Planos Diretores de Seropédica e de Nova lguaçu o AMRJ é mencionado no texto, mas não é demarcado nos mapas. Ao desenharmos o AMRJ em cima dos mapas de zoneamento do Plano de Seropédica (Figura 10), percebemos que o AMRJ irá cortar uma "Zona de Interesse Ambiental (ZIA)" e Áreas de Expansão Urbana. Essa zona ambiental é a Floresta Nacional Mario Xavier, que no PDAM não aparece integralmente representada como área de conservação. De forma contraditória ao proposto no PDAM, o décimo terceiro artigo do Plano de Seropédica define que a integração do território municipal será feita tomando como medida a definição de rotas viárias alternativas para o trânsito de produtos perigosos dentro do município, evitando a travessia desses produtos próximo a Áreas de Proteção Ambiental (APA) e a áreas urbanas. Situação similar acontece em Nova lguaçu, onde o Arco corta a APA Rio Douro e tangencia as APAs Tinguazinho, Tinguá e Retiro (Figura 11). 


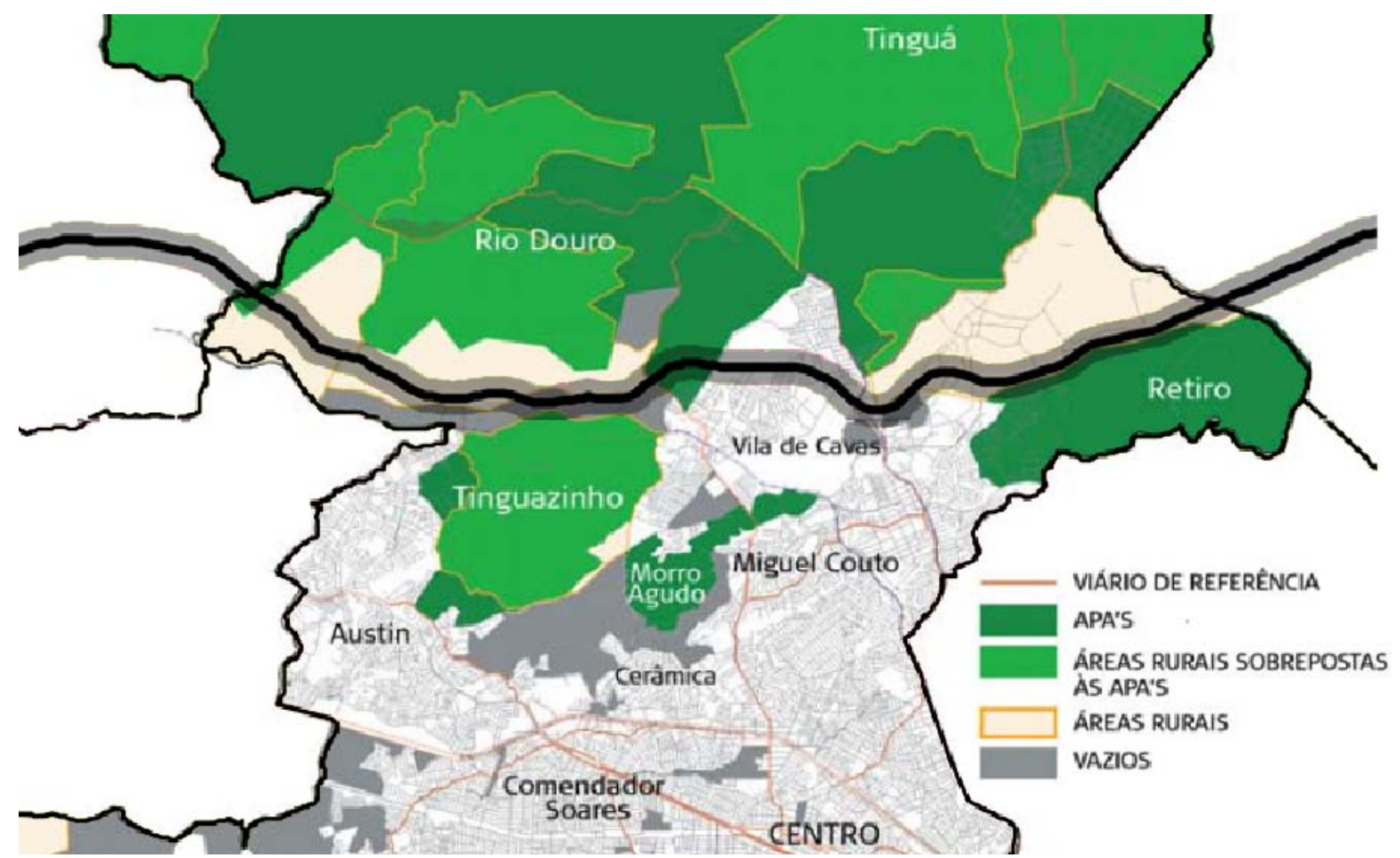

Figura 11 - 0 AMRJ nas APA's de Nova lguaçu. Fonte: Elaboração própria, com dados do PD de Nova lguaçu e do PDAM, 2012.

No caso do Plano Diretor (PD) de Duque de Caxias, apesar do traçado ser apresentado nos seus mapas, o AMRJ não era citado no texto em nenhum momento. Porém, um ano após a aprovação do Plano, o prefeito encaminhou um projeto de lei aprovado pela câmara municipal que reviu o macrozoneamento de modo a adaptá-lo ao traçado do Arco Metropolitano. Embora o PD defina que este tipo de mudança deve, necessariamente, ser apresentado ao conselho municipal de desenvolvimento da cidade de Duque de Caxias, o projeto de lei de alteração do Plano Diretor não passou por nenhum processo de discussão com a população nem foi objeto de audiência pública. 0 sétimo artigo do PD de Duque de Caxias coloca como diretriz a recuperação dos passivos ambientais dentre eles a contaminação da Cidade dos Meninos e o Polo Petroquímico, reconhecendo assim, em 2006, que a área adjacente ao AMRJ já possui diversos problemas derivados da instalação do setor industrial. Contudo, o PDAM demarca a área conhecida como Cidade dos Meninos como simples vazio urbano e não como área de restauração, não levando em consideração que a área ainda representa sérios problemas de contaminação.

Ao citarem o AMRJ, alguns Planos Diretores buscaram aproveitar os investimentos do governo federal e estadual em benefício do município, mas poucos se preocuparam com os impactos negativos do mesmo. Um exemplo é o PD de Magé, onde está previsto o aproveitamento da posição estratégica do município para o seu desenvolvimento 
econômico. Porém, não são mencionadas, em nenhum momento, diretrizes específicas que objetivem preparar o município para o impacto que a nova rodovia causará nos seus padrões sociais e ambientais.

Caso semelhante ocorre no PD de ltaguaí, que foi estruturado de forma a contemplar os investimentos que serão feitos pelo setor público estadual (Arco Rodoviário) e pelo Porto de Itaguaí. Segundo avaliação da Fundação Centro de Defesa dos Direitos Humanos Bento Rubião (FCDDHBR), estes investimentos priorizam a área de expansão industrial. 0 Plano estabelece “Zonas Estratégicas de Negócios" próximas ao AMRJ. Porém, como ocorre também em outros Planos, nos trechos em que aborda a questão da infraestrutura urbana, habitacional e de serviços públicos, o PD de ltaguaí não coloca claramente as necessidades que serão geradas, num futuro próximo, devido aos impactos de tais obras e estímulos ao estabelecimento de indústrias.

Por ser um município com deficiências nos setores de infraestrutura urbana, habitacional e de serviços públicos, seria preciso que todos esses fatores (o AMRJ, o COMPERJ e seus impactos) fossem levados em conta no Plano Diretor, de forma que este passasse a coordenar ações de ordenamento da ocupação e do uso do solo compatíveis com as perspectivas de investimentos. (...)

Dessa forma, a gestão social do Plano, a implementação de suas diretrizes e a elaboração das leis específicas, bem como a elaboração de Plano municipal de Habitação, Saneamento, Meio Ambiente ficam comprometidas e não há garantias de que cheguem a ser formuladas (FCDDHBR, 2008a, p.19-20).

O caso do Plano Diretor de Itaboraí é ainda mais grave, uma vez que este abrigará o COMPERJ. Segundo avaliação de Nacif e Name $(2009)^{39}$, embora a cidade de ltaboraí apresente graves índices de saneamento, o seu Plano não possui um diagnóstico sobre saneamento ambiental e também não prevê instrumentos para a resolução deste problema. Por isso, os autores ressaltam como diretriz para o futuro "criar e manter atualizado cadastro das redes e instalações”. Não tendo informações básicas sobre a sua rede de esgotamento, o Plano não avançou muito no seu tópico de diretrizes, colocando apenas itens como: "111 - completar as redes de coleta e afastamento dos esgotos, encaminhandoos para tratamento nas atuais estações" ou "IV - incentivar a implantação de novos sistemas de tratamento de esgotos e de abastecimento de água”. Nacif e Name (2009) ainda colocam a não preocupação do Plano sobre os impactos do Arco e do COMPERJ.

\footnotetext{
${ }^{39}$ Disponivel em: < http://www.observatoriodasmetropoles.ufrj.br/itaborai.pdf>. Último acesso em março de 2012.
} 
No que diz respeito aos aspectos físico-territoriais, apesar de definir um Macrozoneamento e Zoneamento, o PD não aprofundou os possíveis impactos do COMPERJ - Complexo Petroquímico do Rio de Janeiro na medida em que sua aprovação, para atender as determinações de prazos do Ministério das Cidades, deixou para os Planos Regionais tal tarefa. (NACIF, NAME, 2009, p.6)

Apesar de elaborar o seu zoneamento, alguns Planos não definem muito bem os parâmetros urbanísticos, como é o caso do Plano Diretor de Magé. Este Plano não estabelece limites para expansão urbana nem para ocupação dos vazios do interior de áreas urbanizadas. Com isso, há o sério risco de aumento significativo de densidade construtiva em áreas não preparadas para tal.

Já o Plano Diretor de Duque de Caxias possui detalhamento de coeficientes de aproveitamento para cada área. Como ocorre em muitas cidades brasileiras, o coeficiente básico do município é 1,0 (um). Porém, o zoneamento aprovado na audiência pública de apresentação do $\operatorname{Plano}^{40}$, permite que em alguns trechos do entorno do Arco esse coeficiente seja elevado para 4.8, mediante pagamento de outorga onerosa. É o caso do trecho demarcado como "Zona Especial de Negócios (ZEN) - De indústrias e Centros Distribuidores" (figura 12), localizado adjacente ao AMRJ e próximo ao seu encontro com a Rodovia Washington Luis (BR-040). Nesse trecho, o PD de Caxias, pela sua redação, dá margem à interpretação de ali ser uma zona não restritiva à instalação de indústrias poluidoras ao determinar o:

Uso predominantemente industrial, preferencialmente, destinada à instalação de indústrias cujos processos, submetidos a métodos adequados de controle e tratamento de efluentes, não causem incômodos sensiveis às demais atividades urbanas e nem perturbem o repouso noturno das populações vizinhas (DUQUE DE CAXIAS, 2006, Grifo nosso)

\footnotetext{
${ }^{40}$ Não foi possível ter acesso ao novo macrozoneamento aprovado por lei um ano após a conclusão do Plano Diretor. Segundo trabalho da Rede de Avaliação e Capacitação para a Implementação dos Planos Diretores Participativos, os "Membros do Conselho entrevistados para essa pesquisa declararam que sequer tiveram acesso aos mapas do macrozoneamento incluídos como anexo no PD".
} 


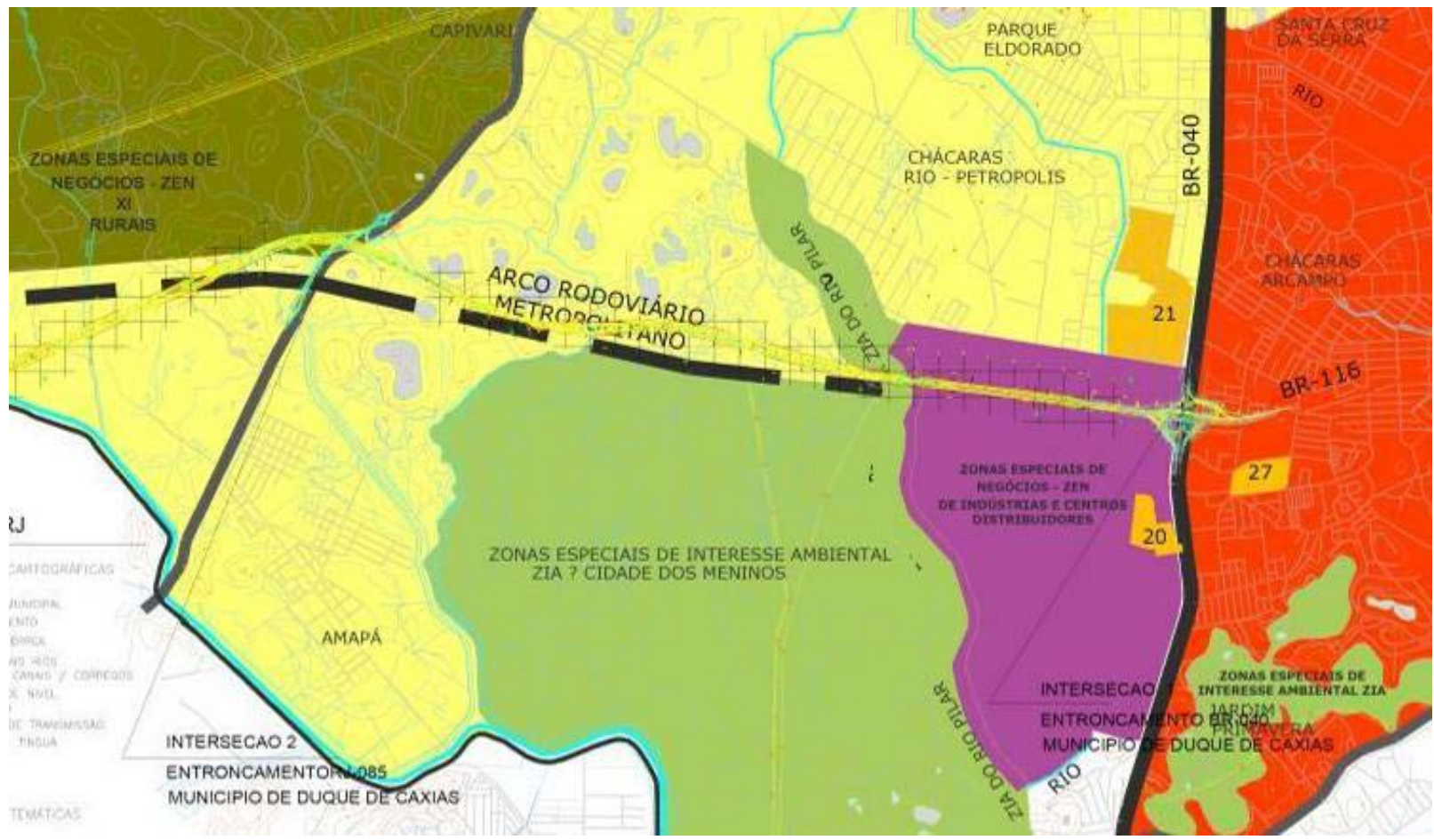

Figura 12 - Trecho do AMRJ sobre o zoneamento do PD de Duque de Caxias. Fonte: Elaboração própria, com dados do PD de Duque de Caxias (2006) e do PDAM (2011).

Em Seropédica, na sua fração mais ao sul, o AMRJ corta uma grande mancha determinada pelo Plano como “Área Rural” (figura 10). Para este tipo de área, o Plano, no artigo 133, abre a possibilidade para usos industriais e comerciais fazendo apenas a vaga ressalva de que tais usos só serão permitidos "se estiverem atendendo as necessidades da população local”, sem especificar como e quem irá definir quais são tais necessidades.

0 Plano de Nova lguaçu, elaborado em 2008, resgata e valoriza as áreas rurais do município. Isto vai contra o Plano Diretor de 1997, que determinou que todo o território do município fosse considerado urbano, não reconhecendo o meio rural, classificando suas populações como agricultoras urbanas. Tal medida do Plano Diretor de 1997 gerou indícios de que o planejamento territorial do município estava voltado para um modelo de desenvolvimento urbano atrelado às políticas governamentais direcionadas aos interesses imobiliários, como "uma ação planejada, visando à transformação, a priori, no Plano jurídico, do potencial de uso de terras rurais em urbanas" (SPOSITO, 2006, p.123) ${ }^{41}$. Assim, com ideias opostas ao Plano de 1997, o Plano de 2008 demarca áreas rurais e busca consolidá-las. No artigo 14, por exemplo, coloca que a política municipal de

\footnotetext{
${ }^{41}$ In PACífICO, CAPRILES E TINOCO: Os Planos Diretores (1997-2008) da cidade de Nova lguaçu: Uma análise do (re) ordenamento territorial do município e a questão rural. 2010.
} 
desenvolvimento rural "terá como objetivo promover as atividades rurais do município e garantir as condições dignas de vida para a população moradora da área rural”.

Contudo, esta tentativa de promoção das atividades rurais pode ser parcialmente frustrada com a implantação do Arco, uma vez que o mesmo corta uma parte significativa dessas áreas rurais. Baseado no próprio Plano de 2008, acreditamos que essas áreas sofrerão um grande impacto, já que o artigo 147 afirma que dentre as "condições para o desenvolvimento da atividade industrial" está a diretriz de "apoiar a implantação de um eixo de desenvolvimento econômico ao longo do Arco Metropolitano”. Logo, provavelmente, tal eixo ocupará o espaço reservado para área rural.

\subsubsection{Posicionamento dos municípios}

Conforme já colocado por Cardoso e Araújo (2012), tanto os estudos da FIRJAN (2008) quanto o RIMA (2007), atribuem ao poder público toda a responsabilidade no que diz respeito à solução dos problemas advindos com o AMRJ. Tais problemas podem ser dos mais variados aspectos, sejam eles socioespaciais, econômicos ou ambientais. Desta forma, cabe às empresas geradoras destes impactos apenas o bônus da sua reprodução.

De forma geral, o Plano sugere que sejam feitos investimentos municipais (delegando, assim, aos municípios a resolução dos problemas) e que seja revisto o modelo institucional de gestão. Para tal, o Plano propõe um sistema de indicadores que coordenaria a gestão compartilhada da RMRJ e a criação de um órgão responsável pela governança da Região Metropolitana, em parceria com os municípios e com a participação da sociedade civil.

Como diretriz de governança, o PDAM reforça essa ideia indicando a necessidade urgente de ampliar a atuação do governo estadual como ente articulador e indutor de políticas públicas na região. Assim, cabe ao estado apoiar os municípios com o objetivo de potencializar o aproveitamento das oportunidades e enfrentar as eventuais dificuldades.

O Plano deixa clara a sua preocupação com as estruturas de administração municipal, demonstrando que elas são extremamente deficientes. Por isso, o documento previne que, sem a melhoria das mesmas, não será possível absorver os benefícios que o Arco e os empreendimentos estruturantes podem trazer para a região. Assim, nas proposições desse órgão de gestão da Região Metropolitana, o PDAM relata itens 
importantes, como: melhorias das administrações públicas municipais; atualização dos instrumentos de ordenamento territorial; e revisão orçamentária de todas as cidades da RMRJ para que estas tenham políticas, planos e programas integrados.

Além das necessidades de apoio específico aos municípios já apontadas nessas diretrizes, sugere-se atenção inicial para as áreas planejamento urbano e controle urbanístico, cadastro multifinalitário, planta genérica de valores; criação/modernização de normas e procedimentos fiscais; planejamento dos sistemas de transporte, saneamento básico e drenagem, entre outros (PDAM, 2011 p.699).

No entanto, o documento admite que este é um enorme desafio e que as deficiências enfrentadas pelas municipalidades são tantas, que ao citar as áreas prioritárias, o Plano elenca inúmeros setores. Desta forma, tal documento deixa transparecer a fragilidade e a impossibilidade de serem cumpridos tantos requisitos para que os municípios possam aproveitar os benefícios do Arco e não sofrer impactos negativos.

Ainda assim, o PDAM apresenta diretrizes quase utópicas de serem implementadas, como: assegurar que o desenvolvimento da região de influência do Arco Metropolitano ocorra de forma racional, integrada e sustentável; e ainda, promover grandes projetos integrados para bairros verdes para comportar diferentes grupos de renda em áreas adensáveis e nos vazios urbanos, visando assim permitir a apropriação social da valorização imobiliária.

Aparentemente, as municipalidades acataram a perspectiva empreendedorista neodesenvolvimentista ditada no âmbito federal (REG0, 2011). Inclusive, algumas cidades, como no caso de Magé, estão mais preocupadas com a possibilidade de aumento de arrecadação fiscal do que com todos os prováveis malefícios gerados pelos impactos socioambientais do Arco. Assim, elas entraram na disputa pela atração dos investimentos privados, usando o AMRJ como uma das fontes de atração, além de incentivos fiscais, etc. (CARDOSO E ARAÚJO, 2012).

Magé criou até slogans citando o Arco Metropolitano, valorizando sua localização estratégica para instalação de empresas. Segundo divulgação da prefeitura, o governo local tem investido também em infraestrutura, buscando transformar o município em um local atraente ao empresariado. Além dos incentivos fiscais de isenção de impostos e taxas, Cardoso e Araújo (2012) destacam que Magé também buscou adequar sua legislação para facilitar a concessão de alvará e funcionamento, para que o empreendedor legalize sua empresa em até quarenta e oito horas. 
[...] destaca-se o município de Magé, cuja prefeitura recentemente tem investido em propagandas utilizando-se de slogans diretamente voltados à captação de empresas e indústrias, tendo como atrativos as grandes obras que estão sendo instaladas na região, tais como: "a cidade está situada no caminho do desenvolvimento, entre a Refinaria e o Polo Petroquímico, ligada pelo Arco Metropolitano!"; "localização privilegiada e natureza encantadora!"; "dispõe de muitas áreas livres e planas, prontas para receber o investidor!”; e, por fim, "Magé é hoje o lugar mais viável para implantação de empresas, por sua localização, sua malha viária, acesso marítimo, Arco Metropolitano e o grande potencial natural para o turismo!" ${ }^{42}$. (CARDOSO E ARAÚJO, 2012, p. 104).

Além disso, o planejamento municipal de Magé ignora as características do suporte biogeofísico e culturais e ainda aborda textualmente as questões ambientais, porém não as espacializam adequadamente. (REGO, 2011). Assim, o Plano Diretor foca no desenvolvimento industrial e não considera os problemas socioambientais que provavelmente serão gerados pelo Arco.

Cardoso e Araújo (2012) demonstram ao longo do seu texto que o projeto de implantação do AMRJ foi revestido de um discurso ideológico a tal ponto que passou a ser defendido não somente pelas empresas envolvidas e governos federal e estaduais, como também pelas administrações municipais e população atingida. Assim, cada vez menos são questionados os impactos ambientais e socioespaciais inerentes a este processo. Tais impactos são vistos cada vez mais como algo necessário para se ter melhorias socioeconômicas. Assim, se cria uma trama discursiva em prol de interesses do capital privado.

Entretanto, o que se percebe é uma naturalização cada vez mais agravada do uso dos fundos públicos para subsidiar empenhos empresariais, onde se intenta maquiar uma real "ampliação para menos" imersa em uma relação de chantagem, na qual, parafraseando Guattari (1977), na sociedade capitalista o Estado é um instrumento fundamental para o sistema de controle, portanto, uma espécie de mediador da produção de subjetividade hegemônica, onde qualquer tipo de produção cultural, social ou de troca econômica, tende a passar por sua tutela e intervenção. (CARDOSO E ARAÚJO, 2012, p. 114).

\footnotetext{
${ }^{42}$ Propaganda oficial da Prefeitura Municipal de Magé, disponível em: <http://www.youtube.com/watch?v=DZ 1qK7NUl5k> e outras informações <http://www.elizeupires.com/2010/07/mage-disputa-empresas-do-polo. html> último acesso: setembro de 2011.
} 


\subsection{Adiamentos e promessas}

Apesar de o Arco ter sido anunciado desde o início de 2007, a cerimônia solene de assinatura de início das obras só ocorreu em maio de 2008, quando foi estabelecido o prazo de inauguração do AMRJ para o final do ano de 2010. Ao longo de sete anos, as obras do AMRJ sofreram atrasos justificados pelos mais diversos motivos. Dentre estes, os que ganharam maior destaque na mídia foram a descoberta de sítios arqueológicos ao longo da rodovia, a descoberta de espécies raras de rã e peixe na Floresta Nacional Mário Xavier (cortada pelo traçado do Arco) e a falta de matéria-prima para as obras. A lentidão na desapropriação dos terrenos que seriam utilizados na obra também foi um motivo bastante relevante, segundo as entrevistas realizadas com representantes de entidades relacionadas com a obra do Arco. Entretanto, esta justificativa não ganhou muita repercussão e sempre foi negada pelos representantes do poder público.

Antes de acabar o prazo inicial, em agosto de 2010, o governo do Estado publicou no Diário Oficial do Estado do Rio de Janeiro o adiamento das obras para o segundo semestre de 2011. O subsecretário de Infraestrutura da época, José Antônio Portela, declarou ao portal 'R7 ${ }^{43}$ que a obra seguiria normalmente seu cronograma, já que as principais questões já haviam sido solucionadas, chegando a afirmar que nem mesmo a descoberta de novos sítios arqueológicos poderia atrapalhar a construção.

Em julho de 2011, o jornal EXTRA (2011) noticiou que apenas 35\% das obras no trecho 'C' já estavam concluídas. Nesse contexto, Fabíola Gerbase, autora da matéria, afirma que "O ritmo das obras do Arco Metropolitano do Rio terá de ser aumentado em mais de três vezes para que elas sejam entregues em dezembro de 2012". Ela coloca que "o vicegovernador e secretário estadual de Obras, Luiz Fernando Pezão, voltou a usar as pererecas como justificativa para o descumprimento dos prazos”, mas na sua visita à obra, ela constata que "mesmo onde as pererecas estão fora do caminho do Arco, não há um único trecho da estrada pronto".

\footnotetext{
${ }^{43} \mathrm{Em}$ matéria veiculada no dia 06 de setembro de 2010. Disponível no link: noticias.r7.com/cidades/noticias /governo-do-rio-adia-para-2011-conclusao-de-arco-metropolitano-20100906.html. Último acesso em novembro de 2013.
} 


\section{EXTRA Notícias Rio Trânsito}

\section{1/07/11 23:33 21/07/11 23:36 \\ Estado só fez $35 \%$ dos 70,9 km do Arco Metropolitano, que ligará Itaboraí ao Porto de Itaguaí \\ Fabiola Gerbase (fabiola gerbase@oglobo.com.br)}

Figura 13 - Arco com só 35\% das obras do trecho 'C' concluídas em meados de 2011. Fonte: EXTRA (2011).

O jornal EXTRA (2011) ainda expôs que o segmento "D" era o mais atrasado. Um consórcio formado pelas empresas Delta e Oriente eram as contratadas para executar esses 20 quilômetros de duplicação. Em 2012 uma matéria do Jornal do Brasil revelou que a Delta abandonou as obras do Arco sem sequer ter montado o canteiro de obras. 0 texto revela ainda que a empreiteira (que tem entre os sócios um amigo do então governador Sérgio Cabral ${ }^{44}$, Fernando Cavendish, alvo das investigações da "CPI Mista do Cachoeira") abandonou a obras após ter problemas com fornecimento de areia e pelas dificuldades no licenciamento ambiental.

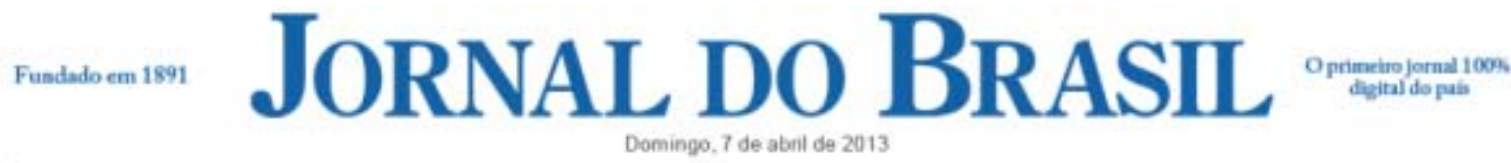

Rio

\section{Delta abandonou Arco Metropolitano; obra está sem data para ser inaugurada}

Previsăo inicial da entrega era para 2010. Construtora nem montou canteiro de obras

Figura 14 - Notícia sobre abandono de obras no trecho da DELTA Fonte: Jornal do Brasil, 2012.

Esta mesma notícia informava que o ex-diretor do DNIT Luiz Antônio Pagot afirmou, no seu depoimento à Comissão Parlamentar de Inquérito (CPI) do Cachoeira, que a DELTA, desde a assinatura do contrato, em fevereiro de 2010, fez de tudo para protelar o início da construção. Pagot considerou essa atitude "estranha”, já que não iniciando a obra, a construtora também não receberia o repasse dos recursos. Em nota divulgada no dia 12 de setembro de $2011^{45}$, a Delta Construção diz que o trabalho não foi iniciado no trecho entre Manilha e Santa Guilhermina (Manilha-Magé) em "virtude de um sítio arqueológico que elevaria os custos, muito acima do valor contratual”. Na nota, a Delta ainda destacou

\footnotetext{
44 do Partido do Movimento Democrático Brasileiro (PMDB)

${ }^{45}$ Disponível no link: www.jb.com.br/rio/noticias/2012/09/12/delta-diz-que-sitio-arqueologico-impediu-obrano-arco-metropolitano/. Último acesso em novembro de 2013.
} 
que não participa mais do trecho referido, mas continua participando de outros consórcios no trecho referente ao lote 4 (Seropédica-ltaguai), onde o trabalho já foi iniciado.

Entre 2011 e 2014, o governo do estado do Rio de Janeiro noticiou com certa periodicidade, no site Secretaria de Estado de Obras (SEOBRAS), o avanço das obras do Arco. No mesmo período, veículos da grande mídia apontaram que as notícias da SEOBRAS mostravam um cenário que não correspondia à realidade e eram demasiadamente otimistas.

Em outubro de $2012^{46}$, por exemplo, enquanto a SEOBRAS (2012) garantia que 65\% do trecho 'C' já estava concluído e que a obra seria entregue em dezembro de 2013, após um voo sobre a área, repórteres do jornal O GLOBO (2012) constataram que o Arco não tinha sequer um quilômetro de asfalto.

Em fevereiro de 2013, como outro exemplo, o jornal 0 DIA (2013) também publicou a previsão do secretário estadual de Obras, Hudson Braga, de que as obras do trecho 'C' do Arco estariam concluídas em dezembro de 2013. Além disso, ele teria afirmado que todos os imprevistos já teriam sido superados. Ocorre que, faltando apenas dois meses para o final deste prazo, em 09 de outubro de 2013, a Secretaria estadual de Obras divulgou que apenas 78\% do projeto tinha sido executado.

Somente em junho de 2014, após várias prorrogações e restando apenas três meses para as eleições dos cargos de governador e de presidente, é que a obra foi de fato inaugurada pela presidente Dilma Rousseff e pelo governador Luiz Fernando Pezão, ambos reeleitos meses depois.

Apesar de inaugurado, o Arco não estava finalizado. Na semana seguinte à cerimônia de inauguração, uma equipe do jornal RJTV 1ª EDIÇÃO, percorreu o Arco e apontou diversas questões, como: falta de sinalização (ou sinalização deficitária), trechos em obra e trechos operando em mão dupla, porque apenas um sentido da pista estava pronto.

\footnotetext{
${ }^{46}$ Escrita por Elenilce Bottari. Disponível no link: oglobo.globo.com/rio/obra-de-arco-metropolitano-nao-temsequer-1 km-de-asfalto-6311068. Último acesso em novembro de 2013.
} 


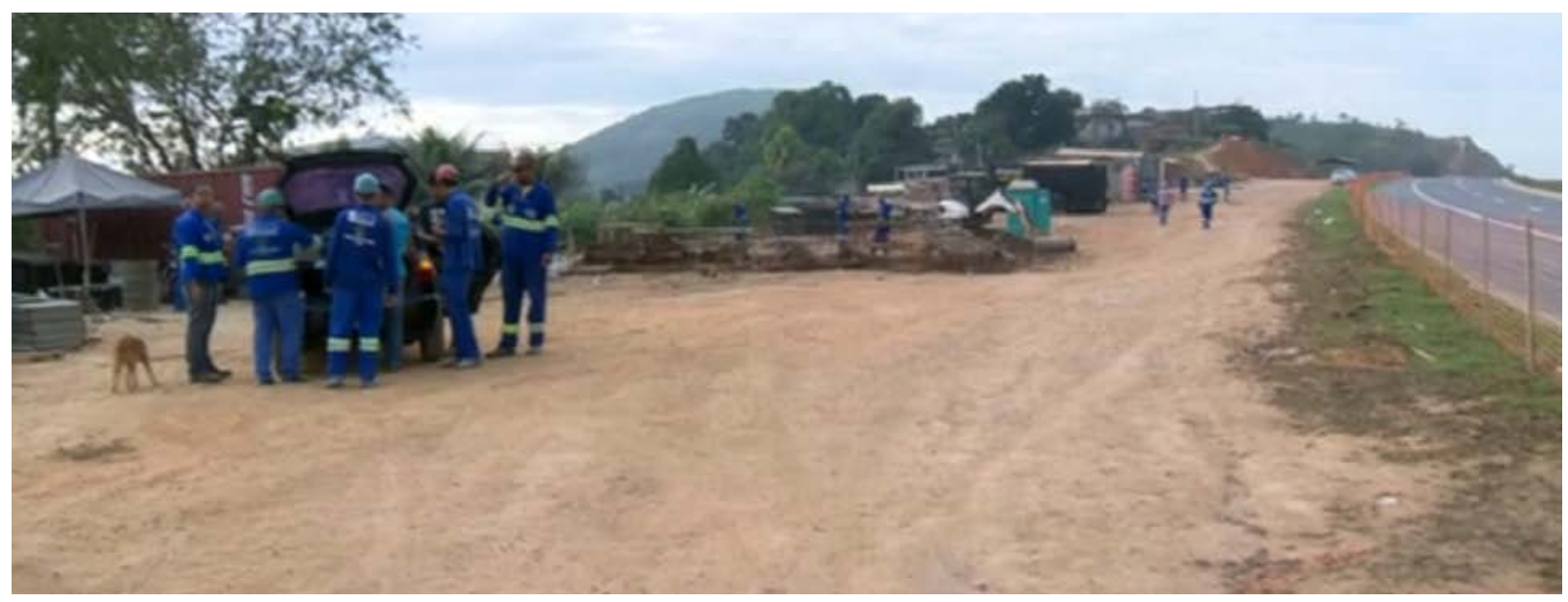

Figura 15 - Canteiro de obra funcionando após inauguração do Arco. Fonte: RJTV 1a EDIÇÃO (2014).

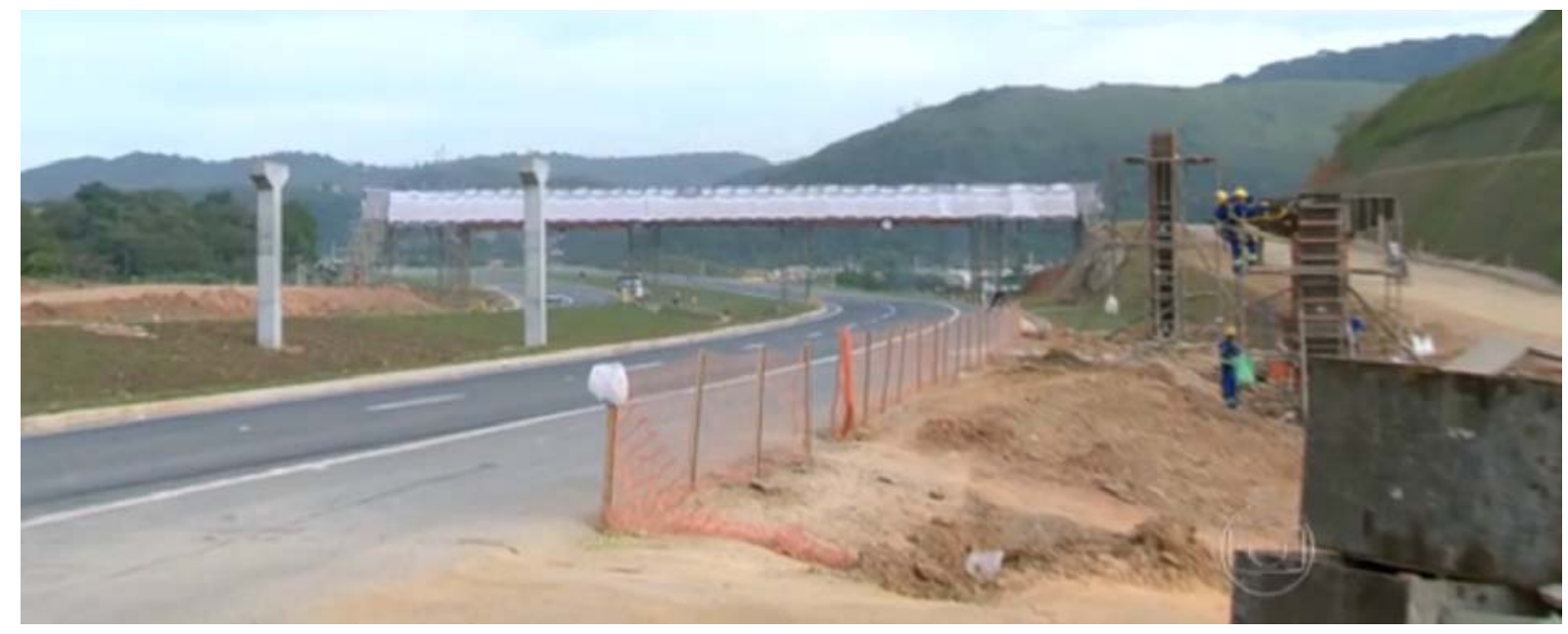

Figura 16 - Passarela para pedestre sendo construída após a inauguração do Arco. Fonte: RJTV 1ª EDIÇÃo (2014).

Seis meses após a inauguração, as obras não haviam sido concluídas. Ainda era possível ver: materiais espalhados pelas laterais da via, máquinas em funcionamento, passarelas de pedestres em execução e problemas de sinalização viária.

Conforme mostrou a reportagem do portal de notícias EXTRA (LINS, 2015), alguns moradores das áreas lindeiras ao Arco reclamavam da falta de conexão entre os dois lados da rodovia e do matéria- prima deixada pelas construtoras nos arredores da rodovia. Esta situação, gera excesso de poeira e, em dias de chuva, de lama, que, em alguns casos, chega a invadir as residências mais próximas à rodovia.

Indignada, a dona de casa Carla Falcão, de 40 anos, faz questão de explicar a situação:

- 0 pessoal da obra deixou essa parte na frente da minha casa cheia de barro. Quando chove, vira uma cachoeira e a lama vem toda para cá. Eles 
melhoraram a situação dos motoristas, mas não deram a mínima para quem mora na região há anos. Estou aqui há 17 e nunca foi assim. É um absurdo.

Ela também reclama da falta de passarelas para pedestres no local.

- Estava acostumada a ir visitar amigos do outro lado, agora há uma rodovia entre nós - disse Carla. (LINS, 2015), 
Capítulo 3: 


\section{Capítulo 3:}

\section{Principais justificativas e contradições do AMRJ: aspectos socioeconômicos, e a estruturação do território}

Como vimos, o Arco cria uma nova conexão entre as principais rodovias da Região Metropolitana fluminense. Essa conexão se dá em áreas pouco populosas. Assim, a nosso ver, essa rodovia será de grande validade para uma futura estruturação do território metropolitano, sobretudo no que diz respeito à expansão urbana. Como toda nova via de uma malha rodoviária, o Arco se faz útil por aumentar a conectividade entre as vias existentes. Assim, gostaríamos de esclarecer, de antemão, que a análise crítica que aqui será feita não tem como objetivo apontar o Arco como uma obra inútil que não deveria ter sido executada.

Contudo, precisamos mostrar que o caso do Arco chama atenção pelas decisões relacionadas ao modo como a rodovia foi construída. Assim, questionaremos aqui itens como o traçado e a tipologia dessa rodovia, mostrando que, ainda que a rodovia fosse uma obra prioritária para a mobilidade metropolitana, ela poderia ter sido feita de forma a causar menos impactos ao meio ambiente.

0 mesmo ocorre com os desdobramentos da rodovia. É claro que a criação de industrias é importante para a economia do Brasil. Reiteramos novamente, que o ponto em questão aqui não é criação de toda e qualquer indústria e sim o tratamento que se dá a essa industrialização e ao aumento da mancha urbana estruturado pelo Arco e impulsionado pela instalação de novas industrias. A intenção aqui é lembrar que políticas públicas de estruturação do território devem ser pensadas de forma coesa. A criação de uma via e o incentivo à instalação de indústrias em uma área pouco ou não urbanizada (como o entorno do Arco) devem, necessariamente, ser acompanhados de medidas de urbanização e de prevenção de impactos negativos.

Esperamos que fique claro que a questão aqui colocada diz respeito à relação custo/benefício desta obra para a população da RMRJ. Insistimos que não temos a intenção de negar que o Arco trás benefícios. 0 nosso objetivo é abordar quais os reais benefícios da obra para a população e quais os prejuizos, tendo em vista que a obra custou 1,9 bilhões e gerou impactos sociais e impactos ambientais negativos. 
Desta forma, trabalhamos essa equação de custos versus benefícios e, ao mesmo tempo, buscamos revelar como o discurso daqueles que defendem o Arco mostra, de forma minimizada os custos e, de forma maximizada os benefícios. Assim, analisamos a presença do discurso ideológico no caso do Arco, ao debater as suas justificativas de implantação, presentes nos principais documentos de informação sobre este empreendimento.

A nossa critica diz respeito, sobretudo, à forma como os setores mais beneficiados pelo o Arco, através de um Estado Patrimonialista, usaram de um discurso ideológico para convencer à população de que o Arco era obra prioritária e fundamental para toda sociedade fluminense, ainda que ele causasse impactos socioambientais negativos.

Desta forma, nos próximos dois capítulos, apresentaremos dados que mostram que a construção dessa rodovia envolve diversos outros aspectos urbanos além do sistema rodoviário. Uma rodovia deste porte tem como desdobramento diversos fatores complexos e, portanto, deveria ser pensada e implementada em conjunto, por exemplo, com medidas habitacionais, de infra estrutura básica, sociais e ambientais. Contudo, os principais meios de divulgação do Arco focaram em pontos, supostamente positivos, de grande apelo popular e pouco problematizaram os aspectos negativos dessa grande obra. Assim, o que faremos a partir daqui, será analisar criticamente tanto os impactos positivos como os negativos dessa grande obra.

\subsection{Desenvolvimento econômico}

\subsubsection{COMPERJ, porto de ltaguaí e empreendimentos aderentes}

Como vimos no segundo capítulo, o Arco foi idealizado na época do desenvolvimentismo brasileiro de meados do século XX, mas só foi projetado e construído no contexto atual do neodesenvolvimentismo. Pelos documentos analisados, notamos que a maior justificativa do governo federal e estadual para a construção dessa nova rodovia foi a necessidade de escoamento da produção do Complexo Petroquímico do Rio de Janeiro (COMPERJ). Ainda que os portos de São Gonçalo, Niterói e da capital fossem mais próximos 
do COMPERJ, o Plano Diretor do Arco Metropolitano (PDAM) informa que a rodovia visa ligar os dois "empreendimentos âncoras": o COMPERJ e a Província Portuária de Sepetiba, para assim poder viabilizar o escoamento da produção do primeiro pelo segundo (ver figura 17).

Os documentos referentes ao Arco Metropolitano não evidenciam os motivos técnicos da escolha de ltaboraí para a sede do COMPERJ, nem a escolha de ltaguaí para o escoamento de sua produção., Também não evidenciam motivos técnicos para a eleição do modal viário para fazer essa ligação entre os dois pontos. Essas três escolhas políticas foram feitas sem nenhuma discussão com a população e sem apresentar argumentos técnicos que as respaldassem.

Figura 17 - 0 AMRJ e a RMRJ. Fonte: Elaboração própria com dados do DER-RJ (2006), do PDAM (2011) e da SUPERVIA (2015).

Com o início da montagem do COMPERJ, a Petrobras encontrou grandes dificuldades para o transporte dos equipamentos mais pesados. Em 2011 chegaram ao porto da capital equipamentos importados que pesam cerca de mil toneladas. Observando que as rodovias existentes do Estado não suportavam todo este peso, a empresa solicitou ao governo fluminense o aval para criação de um porto em São Gonçalo, como forma de acesso definitivo, e o uso do rio Guaxindiba para acessar provisoriamente a obra da nova refinaria. 0 acesso pelo rio foi negado pela Secretaria Estadual do Ambiente, por este fazer parte da Área de Proteção Ambiental de Guapimirim, sendo certo que a dragagem necessária para a passagem das embarcações da Petrobras afetaria muito o ecossistema da 
região (BOURSCHEIT, 2013; VEJA, 2012). Já o porto em São Gonçalo, localizado na Praia da Beira, no bairro de ltaoca, teve licença aprovada em 2012.

Pela análise de fotos aéreas ${ }^{47}$, podemos ver que, no início de 2013 , as obras do porto de São Gonçalo já estavam em andamento. As imagens de meados de 2013 evidenciam o surgimento de uma rodovia, cujo traçado da obra indica uma provável ligação entre o porto de Itaoca e a BR-101, no trecho conhecido como Rodovia Niterói-Manilha.

Com essa estrada, a distância entre o COMPERJ e o porto de ltaoca será inferior a trinta quilômetros, ao passo que a distância entre o COMPERJ e o porto de ltaguaí é superior a cento e quarenta quilômetros. Essa significativa diferença de distância e a inicial exclusividade $^{48}$ da Petrobras no porto de ltaoca, levantam a hipótese do COMPERJ não precisar do Porto de ltaguaí para escoar a sua produção. Tal hipótese possibilidade também foi publicizada em uma matéria do jornal O FLUMINENSE (2013), na qual se afirma que o porto de São Gonçalo servirá para atender a obra do COMPERJ e também para escoar a sua produção.

Paralelamente, fica claro no PDAM (2011) que nos últimos anos o governo estadual e empresas privadas vêm investindo bilhões na Província Portuária da Baía de Sepetiba. Tais investimentos são feitos com empreendimentos do setor industrial e logístico em ltaguaí e em outros locais cortados pelo Arco Metropolitano. Além do AMRJ, do porto de ltaguaí e do COMPERJ, também foram alvo dos investimentos do PAC na RMRJ a Companhia Siderúrgica do Atlântico (CSA) em Santa Cruz (Rio de Janeiro) e a Companhia Siderurgia Nacional (CSN). Contudo, cabe ressaltar que há inúmeros outros empreendimentos beneficiados economicamente com a construção do Arco, estando eles descritos no Plano como "empreendimentos aderentes".

\footnotetext{
${ }^{47}$ Imagens do Google Earth, entre 2011 e 2014.

${ }^{48} \mathrm{~A}$ construção do porto de ltaoca está sendo feita com recursos da Petrobras. Na negociação entre a empresa e a prefeitura de São Gonçalo foi acordado que o porto será de uso exclusivo da Petrobras. Em caso de expansão futura com outros recursos, o porto poderá atender também outras demandas da cidade (VEJA, 2012).
} 


\begin{tabular}{|c|c|c|c|}
\hline EMPREENDIMENTO & MUNICÍPIO & SETOR & INVESTIMENTO (R\$) \\
\hline $\begin{array}{l}\text { Plataforma Logística CSN } \\
\text { - Expansão TECON } \\
\text { - Expansão TECAR } \\
\text { - Polo Logístico } \\
\text { - Porto Privativo Lago da } \\
\text { Pedra }\end{array}$ & \multirow[t]{6}{*}{ Itaguaí } & \multirow{6}{*}{$\begin{array}{l}\text { Transportes } \\
\text { Logística }\end{array}$} & 4.700 .000 .000 \\
\hline Porto Sudeste LLX & & & 1.500 .000 .000 \\
\hline Porto Petrobras & & & 4.000 .000 .000 \\
\hline Porto Usiminas & & & 1.000 .000 .000 \\
\hline Porto Gerdau & & & 1.100 .000 .000 \\
\hline Porto Itaguaí - CDRJ & & & 86.000 .000 \\
\hline $\begin{array}{ll}\text { CSA } & \\
\text { - } & \text { Usina Siderúrgica } \\
\text { - } & \text { Porto CSA } \\
\end{array}$ & Rio de Janeiro & $\begin{array}{l}\text { Siderurgia } \\
\text { Transportes } \\
\text { Logística } \\
\end{array}$ & 13.100 .000 .000 \\
\hline 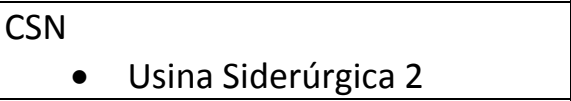 & Itaguaí & Siderurgia & 7.600 .000 .000 \\
\hline Coquepar & Seropédica & Petroquímica & 524.000 .000 \\
\hline REDUC - Ampliação Refinaria & Duque de Caxias & & 1.500 .000 .000 \\
\hline Bayer - Expansão & Belfort Roxo & Química & 100.000 .000 \\
\hline Estaleiro EISA & Rio de Janeiro & & 3.285 .000 .000 \\
\hline STX Europe & & Industria & 1.100 .000 .000 \\
\hline Estaleiro Mauá & Niterói & & 627.200 .000 \\
\hline Estaleiro Aliança & & & 211.000 .000 \\
\hline \multicolumn{3}{|c|}{ TOTAL: } & 40.433 .200 .000 \\
\hline
\end{tabular}

Figura 18 - Investimentos Previstos em 2011 nos “Empreendimentos Aderentes”. Fonte: Elaboração própria com base no PDAM,2011, p.36-37.

Além de destacar que a obra do Arco permite a sustentação desses investimentos públicos e privados (nos "empreendimentos Alicerces" e nos “empreendimentos Aderentes”), o Plano informa que o Arco também contribui para a atração de novos empreendimentos. A Presidente Dilma Rousseff, no discurso de inauguração do Arco, confirmou essa visão ao afirmar que o Arco é um "caminho de oportunidades para instalação de empresas, algumas, inclusive, já instaladas". A governante complementa ainda que acredita que muitas outras empresas virão se instalar ao longo do Arco, pois duvida que exista um outro lugar "tão adequado para se instalar uma empresa como esse Arco Rodoviário" (SITE DO PLANALTO, 2014). Desta forma, o Arco é visto como peça fundamental de um projeto econômico estratégico que visa a significativas transformações da dinâmica econômica da RMRJ. Além disso, segue rumo à diversificação de sua base produtiva e a uma nova organização espacial (PDAM, 2011).

Ao abordar a Província Portuária da Baía de Sepetiba, o PDAM indica que as ligações rodoferroviárias com os portos são pontos fundamentais da rede logística. Por consequência, esses "nós" se transformam em grandes áreas de atratividade de 
investimentos. Assim, a associação do Arco ao porto de ltaguaí e à malha ferroviária ali existente gera uma série de vantagens locacionais, o que pode explicar a enorme quantidade de investimentos que vêm sendo aplicados nessa região. 0 Arco é um reforço desse "nó", uma vez que abre uma nova possibilidade de rota. Antes do Arco, a única alternativa rodoviária era a Rio-Santos (BR-101), que dava acesso ao porto com duas faixas de rolamento, uma em cada sentido. 0 segmento B do Arco duplica a quantidade de faixas de rolamento da Rio-Santos e o segmento C cria quatro novas faixas. Assim, o Porto de ltaguaí, que antes contava com apenas duas faixas, agora é conectado por oito faixas de rolamento. Além dessa expansão bastante considerável, o trecho $\mathrm{C}$ ainda proporciona a este porto uma conexão de forma mais rápida a algumas rodovias interestaduais, ampliando significativamente a acessibilidade da província portuária da Baía de Sepetiba.

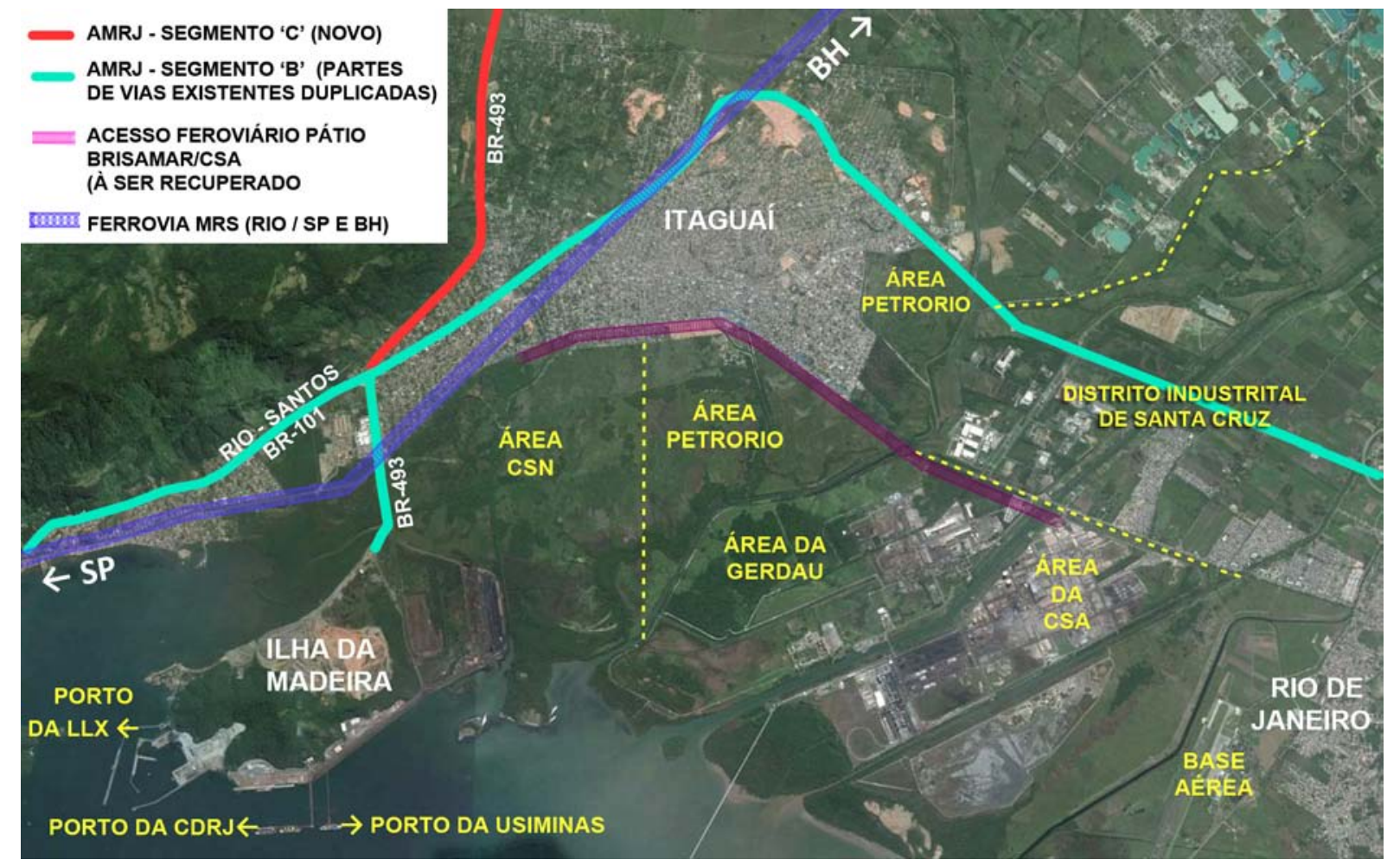

Figura 19 - Província Portuária da Baía de Sepetiba. Fonte: Elaboração própria com base em SETRANS (2007, p.25) e PDAM (2011, p.34).

0 PDAM ressalta ainda que este complexo portuário tem localização chave para escoar as crescentes exportações de minério de ferro do Quadrilátero Ferrífero Mineiro. 0 Arco é um facilitador para que a produção de Minas Gerais chegue até o Porto de Itaguaí pois conecta-o à BR-040, que liga o Rio de Janeiro a Belo Horizonte. Não por acaso, para o Plano o AMRJ é "objeto de desejo de grandes exportadores da cadeia extrativa de minério 
de ferro e de outras cargas (contêineres, geral etc.), considerando que, em um raio de 500 km encontra-se algo como 50\% do PIB brasileiro" (PDAM, 2011, p.29).

Assim, esse conjunto de facilitadores logísticos "está provocando o 'boom' de investimentos portuários no Estado do Rio de Janeiro, especialmente nesse lócus privilegiado" (PDAM, 2011, p.27). Cabe lembrar que tanto os estudos da FIRJAN (2008) quanto o PDAM (2011) afirmam que em decorrência da construção do Arco, há uma previsão de redução de $20 \%$ dos custos de transporte para as empresas do setor logístico. Nesse percentual não estão contabilizados os ganhos indiretos decorrentes do aumento da demanda, e, consequentemente, da segurança do efetivo crescimento do setor logístico na região.

Quatro anos antes do relatório final do Plano, um artigo da SEOBRAS (2007) já via o Arco como o grande escoadouro da produção fluminense e também de grande parte da produção brasileira. Ao ser projetado com possibilidades de expansão (mediante mais faixas de rolamento no canteiro central) o Arco poderá, inclusive, adaptar-se futuramente para ter ampliada a sua capacidade de fluxos de cargas, mantendo assim sua importância durante muitos anos.

0 Plano do Arco vislumbrou muito mais que essas perspectivas iniciais de importância regional e brasileira. Ele salientou que a dinâmica da RMRJ passará por um significativo processo de transformação, e que o Rio de Janeiro poderá se tornar o "principal centro multimodal intercontinental, articulando países da América do Sul com as redes mundiais” (PDAM, 2011, p.167), concluindo ainda que:

Não é descabido pensar que o binômio porto-aeroporto, combinado com serviços sofisticados urbanos que o Rio pode oferecer, venha a compor o portal por onde a América do Sul - principalmente o MERCOSUL - articular-se-á com as correntes comerciais do mundo. 0 Rio será reposicionado na economia nacional a partir de Sepetiba (PDAM, 2011, p.167).

Ao abordar os investimentos portuários, tal documento ainda aponta que o atual modelo nacional de desenvolvimento, associado ao mercado externo, tem buscado solucionar questões de infraestrutura fundamentais para a exportação, reduzindo assim o “custo Brasil”. Nesse contexto, o Arco é inserido como uma peça desse mosaico de demandas que influenciarão profundamente na dinâmica econômica do estado. Essa conexão entre o Porto de ltaguaí, o ARMJ e os ramais ferroviários existentes "transformará a Região Metropolitana em umas das maiores áreas logísticas do mundo, gerando novas perspectivas econômicas regionais” (PDAM, 2011, p.1). 
Pelo exposto, nos parece claro que, embora o discurso de defesa do Arco Metropolitano bata sempre na tecla da importância do escoamento do COMPERJ, o foco, na verdade, é a Província Portuária da Baía de Sepetiba. É ela, e não o complexo da Petrobras, que é vista como o item fundamental para reposicionar o estado do Rio de Janeiro na economia nacional.

Desta forma, com base no que vimos no primeiro capítulo, fica claro que o Arco é uma obra substancialmente desenvolvimentista e visa o crescimento econômico pela via industrial. Podemos ainda identificar no Arco um viés patrimonialista, por ser uma obra pública que atende a diversos interesses privados. 0 Arco custou 1,9 bilhões aos cofres públicos, em nome da viabilização do COMPERJ, que é um grande complexo industrial de capital majoritariamente público. Contudo, conforme mostramos aqui, esta rodovia pode vir a ser completamente inútil para o COMPERJ. Enquanto isto, ele oferece oportunidades para a instalação de novas empresas privadas e beneficia as já existentes, ao criar uma série de facilidades para o setor logístico e, consequentemente, para o escoamento da produção industrial. Algumas dessas empresas estão identificadas no PDAM como "empreendimentos aderentes" enquanto outras são apenas citadas, como é o caso das grandes exportadoras da cadeia extrativa de minério de ferro do estado de Minas Gerais. Além disso, o suposto benefício da rodovia para a população residente no local também pode ser questionado, como veremos a seguir.

\subsubsection{A população local e suas atividades econômicas}

Dentre todos os autores pesquisados, poucos questionam os benefícios desta grande rodovia para as indústrias brasileira. Contudo, muitos discutem os benefícios do Arco para a população existente no seu entorno. Como veremos no próximo item, um suposto benefício para as localidades seria a criação de empregos nas prováveis indústrias que se instalarão ao longo do Arco. Contudo, alguns autores advertem que hoje as pessoas que habitam o local atuam com outras lógicas de trabalho, como é o caso de muitos pequenos produtores rurais.

Segundo Pinto (2010), “os efeitos do Arco Metropolitano poderão impactar a economia local, sobretudo os pequenos produtores, que ainda retiram da agropecuária sua principal fonte de geração de trabalho e renda" (PINTO, 2010, p. 6). Moraes (2013) ratifica 
essa visão, afirmando que a população local é empobrecida e fragilizada, não possuindo voz nem influência no jogo político. Por conta da falta de informações de qualidade, muitos são induzidos a pensar que o Arco aumentará a empregabilidade e gerará um desenvolvimento econômico local benéfico a todos.

Sobre este tema, nos grupos de trabalho das oficinas realizadas pelo SEL-RJ ${ }^{49}$, um dos participantes criou uma frase-conceito na qual se identifica que, devido ao uso do discurso desenvolvimentista, os argumentos de implantação do Arco focam nos benefícios para o transporte de cargas e desconsideram os impactos ambientais gerados e o valor de uso que tem a área de abrangência do Arco para as comunidades tradicionais.

"O Arco Metropolitano é um projeto que visa a ampliação da estrutura viária do Estado do Rio de Janeiro e o aumento da RENDA oriunda do transporte de cargas, entretanto o processo de construção dessa rodovia compromete áreas de CONSERVAÇÃO e preservação ambiental e desconsidera, em função de um discurso desenvolvimentista, o VALOR DO SOLO para as comunidades tradicionais que residem nos municípios por onde o Arco vai passar" (frase-conceito de participante) (ISIDORO, ALCANTARA E TÂNGARI, 2011. p. 11).

Moraes (2013) destaca que o objetivo real da obra está longe de ser a melhoria de vida da população local. Segundo ela, ao analisar os objetivos do Arco, percebe-se claramente que a visão econômica sobrepuja as visões socioambiental e cultural. Assim, ela afirma que, como em outras obras, no caso do Arco, ”a lógica econômica impõe problemas de ordem ambiental, promovendo uma desestruturação de ecossistemas importantes para a manutenção da Baixada Fluminense e, quiçá, de todo o território nacional” (MORAES. 2013). Montezuma (2012) também indica que o Arco não reconhece a importância da vida social e cultural da população, iniciando sua apresentação com uma citação de Pádua (2009):

... é importante lembrar que a vida social e cultural dos seres humanos, que define seus vínculos e identidades, desenvolve-se em espaços ambientais concretos e específicos, dotados de determinadas características ecológicas. Não se trata de determinismo ecológico, mas sim da simbiose necessária entre a realidade biofísica e a condição humana. Não apenas a economia, mas também a memória dos indivíduos e grupos sociais está relacionada com o ambiente vivido. A

\footnotetext{
${ }^{49}$ Grupo de pesquisa do Programa de Pós-Graduação - PROARQ da Faculdade de Arquitetura e Urbanismo da Universidade Federal do Rio de Janeiro. 0 foco principal do grupo é o estudo dos sistemas de espaços livres de edificação e sua relação com o planejamento e desenho urbanos e com a configuração e a dinâmica da paisagem no Estado do Rio de Janeiro. As oficinas locais nos municípios influenciados pelo Arco Metropolitano foram feitas em 2010 como parte da pesquisa "O Arco Metropolitano do Rio de Janeiro Integração e fragmentação da paisagem metropolitana e dos sistemas de espaços livres de edificação". As informações aqui destacadas se referem as oficinas realizadas na Unidade de Paisagem 1 (Itaguaí, Santa Cruz e Sepetiba) e na Unidade de Paisagem 4 (Magé e Guapimirim), conforme setorização da área de influência do Arco Metropolitano determinada pelo SEL-RJ.
} 
paisagem é o elo necessário entre sociedade e natureza. Pádua (2009) (MONTEZUMA. Slide 3).

Aplicando a metáfora da dupla face da mesma moeda, Montezuma (2012) afirma que o ARMJ é uma obra que traz ao mesmo tempo conexões e rupturas. A autora acredita que por conta do Arco, ocorrerá um deslocamento de população residente no entorno da rodovia para áreas mais afastadas. Assim, nos locais cortados pelo AMRJ ocorrerá uma "fragmentação de nucleações como bairros e vilas, assim como de práticas tradicionais e sustentáveis" (MONTEZUMA, 2012, p. 12). Consequentemente, a autora aponta para a formação de espaços segregados tendendo à formação de condomínios fechados, no modelo cidade-bairro, para atender às demandas da classe de alta renda e do desenvolvimento de ocupações informais em áreas menos valorizadas de maneira a atender às demandas das classes de menor poder aquisitivo.

Segundo Freitas e Rodrigues (2014), atividades inseridas e fortemente relacionadas aos ecossistemas que dão suporte à reprodução do trabalho, tais como agricultura familiar, extração vegetal e a pesca artesanal, estão sujeitas a uma escala maior de vulnerabilidade frente aos diferentes tipos de impactos e danos ambientais. Os autores enfatizam que tal vulnerabilidade é potencializada sobretudo, nos espaços determinados pela soma de interesses econômicos e políticos, convertidos em alvos de apropriação e refuncionalização produtiva.

Seguindo essa mesma linha de raciocínio, a pesquisa de lsidoro, Alcantara e Tângari (2011) levanta que no caso do Arco, as comunidades mais frágeis e que têm maior dependência do meio ambiente são as comunidades quilombolas e as pesqueiras. Por tanto, elas foram apontadas como as que têm menos condições de resistir ao avanço especulativo. 1sidoro, Alcantara e Tângari (2011) também lembram que as indústrias siderúrgicas, metalúrgicas e petroquímicas têm alto potencial poluidor. Assim, o crescimento industrial previsto pode afetar a qualidade atmosférica da região e das águas das baías de Guanabara e de Sepetiba. Em decorrência, provavelmente haverá impactos negativos no modo de vida e na sazonalidade da pesca, comprometendo a permanência dos atuais habitantes nessa área.

Assim, Isidoro, Alcantara e Tângari (2011) alertam que caso não sejam tomadas medidas de proteção do patrimônio ambiental, histórico e cultural da região, essas comunidades estão fadadas ao desaparecimento. Para as autoras, a resistência dessa população se caracteriza por um enorme desequilíbrio. De um lado, estão "as pressões das forças globais que têm o apoio e financiamento de instituições federais 
desenvolvimentistas" (ISIDORO, ALCANTARA E TÂNGARI, 2011. p.10) e, do outro, a população carente de serviços de saúde e educação, etc. e que foi historicamente deixada à sua própria sorte.

Em geral, o RIMA (2007) observa de forma mais ampla do que o PDAM (2011) os impactos negativos sofridos pela população local, traçando diretrizes mais claras. Contudo, o recorte geográfico do RIMA (2007) se limita aos espaços lindeiros das área que será ocupada pela rodovia e o recorte temporal se limita à etapa de obra. Devido aos inúmeros impactos negativos do Arco, tanto o RIMA (2007), quanto o PDAM (2011) deveriam ter dado maior peso para o entorno do Arco como um todo. Sobretudo o PDAM, que se propõe ser um documento de planejamento da região para um horizonte futuro, deveria ter traçado diretrizes que pensassem nos aspectos sociais para além do crescimento da oferta de empregos.

Assim, o PDAM (2011) poderia incluir também diferentes ações públicas voltadas para a possibilidade da manutenção da população residente no local. No entanto, o Plano se restringe a abordar a capacitação da mão de obra local para os novos postos de trabalho. Desta forma, uma vez que reconhece as barreiras impostas para que esta população continue com os seus modos de vida e de geração de renda, essa única diretriz é quase uma imposição: ou o morador aprende a trabalhar nas futuras indústrias ou não terá mais como se sustentar naquele local, ocorrendo uma expulsão indireta.

Freitas e Rodrigues (2014) estudam o enfraquecimento da atividades extrativas geradas pela imposição, por agentes públicos e privados, de um novo contexto socioeconômico e produtivo. Em muitos casos são acionados dispositivos que dificultam as práticas e costumes laborais ali enraizados, colocando em risco as atividades ocupacionais existentes e gerando vários tipos de problemas. Em localidades como a Baía de Sepetiba, "as reconfigurações socioeconômicas projetadas afinam-se com o processo de desterritorialização ${ }^{50}$. Com efeito, forjam-se novas relações de poder ao distanciar o trabalhador do seu processo produtivo" (FREITAS; RODRIGUES, 2014, p.2). Desta forma, a desterritorialização é uma importante estratégia para conter, restringir, destituir e excluir grupos e indivíduos de sua relação material e subjetiva com o seu território. No caso do Arco, essas reconfigurações econômicas locais incidem diretamente sobre as populações tradicionais.

\footnotetext{
${ }^{50}$ Segundo Freitas e Rodrigues (2014) a origem do conceito de desterritorialização está relacionada com: Haesbaert R. 0 mito da desterritorialização: do fim dos territórios à multiterritorialidade. Rio de Janeiro: Bertrand Brasil; 2004.
} 
Isidoro, Alcantara e Tângari (2011) contam que a população de Itaguaí vem sendo impedida e indiretamente expulsa de suas áreas originais pela pressão dos empreendimentos instalados na província portuária de Sepetiba (figura 19). Nesse sentido, as autoras defendem que o aumento do fluxo de navios na Baía de Sepetiba impactará diretamente na atividade dos pescadores tradicionais. Sendo assim, ele é determinante para a redução ou eliminação das atividades pesqueiras e dos grupos que delas subsistem.

Segundo Freitas e Rodrigues (2014) e lsidoro, Alcantara e Tângari (2011), nos últimos anos, na Baía de Sepetiba, ocorreu uma diminuição das áreas permitidas às atividades primárias de pesca e terciárias de turismo em função do aumento das faixas de navegabilidade para navios de grande porte e da implantação de portos privativos para escoamento da produção industrial.

...não precisávamos ir tão longe pra pegar o peixe, que nós saíamos aqui perto, em frente e já conseguíamos, mas o que ocorre de um tempo pra cá é que os grandes empreendimentos se instalaram na nossa baía e esse empreendimento causou várias restrições na nossa área de pesca... Pescador 1 (FREITAS; RODRIGUES, 2014, p.6).

Além desses bloqueios aos canais de saída para a baía que serviam às comunidades pesqueiras, nas pesquisas de campo de lsidoro, Alcantara e Tângari (2011), os moradores locais mencionaram a supervalorização imobiliária com a aquisição de inúmeros terrenos e casas pelas grandes empresas. Estas se instalam de forma forte e impositiva, deixando poucas saídas para aqueles que resistem tentando permanecer no local.

Freitas e Rodrigues (2014) apontam que o processo de desterritorialização se inicia na tentativa de isolar o território das suas "raízes" sociais e culturais". Assim, essas alterações impõem inexoravelmente perdas dos elementos simbólicos que ajudaram a modelar identidades, inibem a transmissão de valores socioculturais e provocam movimentos que processualmente avigoram o arrefecimento da memória coletiva. No caso da Baía de Sepetiba, eles lembram que as estratégias de intervenções reconfiguradoras que beneficiam as áreas logísticas, industriais e portuárias, provocam profundas transformações estruturais e paisagísticas, com efeitos negativos sobre aspectos tangiveis e intangíveis.

Para os autores, a depender do grau e da magnitude da refuncionalização e reconfiguração desses territórios, são gerados, inclusive, problemas de saúde. Eles citam alguns modelos conceituais que já foram elaborados e empregados por outros autores que

\footnotetext{
${ }^{51}$ Conforme colocado por Pagés M, Bonetti M, Gaulejac V, Descendre D. 0 poder das organizações: a dominação das multinacionais sobre os indivíduos. São Paulo: Atlas; 1987.
} 
buscavam compreender melhor os nexos causais do âmbito ocupacional relacionados às doenças crônicas não degenerativas. Assim, buscam compreender como a desterritorialização contribui para o aumento de tensões psicossociais e riscos ocupacionais, inerentes às atividades extrativas.

Considerando principalmente o fato de o processo de adoecimento dos indivíduos, no que tange às enfermidades crônicas não transmissíveis, transcorrer da reprodução social no meio em que se vive e trabalha, Freitas e Rodrigues (2014) informam que as restrições de espaço das atividades pesqueiras tiveram impacto direto na saúde dos pescadores. Agora eles precisam se locomover mais, permanecer mais tempo no mar, e também correm riscos por conta da competição pelo espaço náutico com os grandes navios.

Freitas e Rodrigues (2014) entrevistaram um pescador cuja fala ilustra bem essa situação. 0 entrevistado diz que agora ele precisa ir pescar mais longe do que antes, assim, sua carga horária de trabalho no mar aumentou consideravelmente e, com isso, ele fica mais tempo exposto aos raios solares. Essa situação aumenta também o seu cansaço físico e mental, o que potencializa as chances do surgimento de doenças.

Além disso, alguns pescadores se queixam das constantes dragagens feitas nas proximidades dos Portos de Sepetiba cujo objetivo é aprofundar canais de acesso para viabilizar o trânsito de grandes embarcações. Na fala deles nota-se a degeneração do ecossistema da baía decorrente desse processo. Os pescadores ainda explanaram que, por vezes, algumas embarcações de carga passam fora destes canais e adentram as áreas de pesca artesanal, demarcadas por boias. Há relatos de que essa invasão de áreas pesqueira comumente carrega as redes colocadas pelos pescadores e todos os peixes que nelas estavam. Devido à enorme diferença de tamanho entre os pequenos barcos de pesca e os grandes navios de carga, esse desrespeito às áreas dos pescadores artesanais claramente causa sérios riscos à vida deles. Um dos entrevistados de Freitas e Rodrigues (2014) relata a morte de um pescador decorrente do choque de embarcações:

... têm as bóias, o pescador respeita, só que eles não respeitam. Esse ano [2012] mataram um pescador em Coroa Grande. É, porque veio outro, veio pelo lado... Um navio no canal e do outro lado chegou outro...Pra mim foi um crime, porque eles sabem que não podia ta andando daquele jeito... Pescador 8. (FREITAS; RODRIGUES, 2014, p.6).

Freitas e Rodrigues (2014) ressaltam a quase nulidade de investimentos na manutenção, recuperação e proteção da Baía de Sepetiba como ecossistema suporte à produção da vida marinha. Consequentemente, eles apontam para a condição de declínio ou 
estagnação (em um cenário menos pessimista) da pesca artesanal na Baía de Sepetiba. Com isso, os autores ressaltam a enorme vulnerabilidade socioambiental da atividade extrativa da pesca artesanal dessa região, dada pelo aumento do uso do Porto de ltaguaí, evidenciando este conflito de interesses.

Provavelmente não por acaso, tanto o RIMA (2007) quanto o PDAM (2011) não criam políticas públicas para a manutenção das atividades da população local. Essa postura de falta de políticas públicas cria dois possíveis desencadeamentos. 0 primeiro é a expulsão indireta dos moradores da região, sendo que, sobretudo no caso das comunidades de pescadores, essa expulsão gera a liberação de mais terrenos para a instalação de indústrias próximas à área portuária. 0 segundo é a criação de uma grande disponibilidade de mão de obra no local, pois, uma vez impossibilitados de continuarem com suas atividades produtivas, os moradores só possuem a opção de trabalhar nesses novos empreendimentos portuários e industriais. Desta forma, podemos considerar que tanto o RIMA (2007) como o PDAM (2011) colaboram para essa desterritorialização das atividades locais, atendendo assim, aos interesses das atividades industriais, portuárias e logísticas, em detrimento dos interesses da população local.

Conforme já comentado no capítulo 1 do presente trabalho, Ferreira e Ferrara (2012) enfatizam que os recursos naturais findáveis são explorados de forma exagerada e repartida de forma desigual. Segundo os autores, esse processo de apropriação desigual dos recursos naturais é uma forma de desenvolvimento injusto e insustentável.

Cabe lembrar que Acselrad (2010), ao estudar alguns casos brasileiros, caracteriza as lutas por justiça ambiental como uma combinação de: defesa dos direitos a ambientes culturalmente específicos - comunidades tradicionais situadas na fronteira da expansão das atividades capitalistas e de mercado; defesa dos direitos a uma proteção ambiental equânime contra a segregação socioterritorial e a desigualdade ambiental promovidas pelo mercado; defesa dos direitos de acesso equânime aos recursos ambientais, contra a concentração das terras férteis, das águas e do solo seguro nas mãos dos interesses econômicos fortes no mercado.

Com isso, a identificação de um caso de injustiça ambiental precisa mostrar a desigual exposição ao risco como resultado de uma lógica na qual a acumulação de riqueza se realiza tendo por base a penalização ambiental dos mais despossuídos (ACSELRAD, 2010). 
Como vimos, na Baía de Sepetiba ocorre não só uma desigual apropriação dos recursos ambientais, como também uma desigual exposição ao risco decorrente desse desigual uso do meio ambiente. Desta forma, o caso da pesca artesanal neste local, tão bem caracterizado por Freitas e Rodrigues (2014), se encaixa perfeitamente como um caso de injustiça ambiental, como colocado por Acselrad (2010).

\subsection{A geração de emprego}

Como já falamos nesse capítulo, o debate sobre quais setores serão realmente beneficiadas não foi amplamente exposto para a população. Em todos os principais meios de divulgação do Arco fala-se muito da viabilização do COMPERJ e do crescimento econômico, pouco se falando dos benefícios às empresas privadas e dos impactos negativos para a população local.

Concomitantemente, o Arco e o Porto de Itaguaí são vistos como um benefício para a população local devido ao aumento da oferta de empregos e ao aumento da arrecadação de impostos que esse crescimento industrial e logístico poderá gerar. Contudo, não há, por exemplo, informações sobre quais melhorias podem ser realizadas a partir dessa receita tributária. Não há, sequer, estimativas de qual seria esse montante.

No item chamado “Repercussões e Mudanças” do PDAM (2011), é reconhecida a dificuldade em obter informações estatísticas consistentes e detalhadas que dessem suporte para estas estimativas. Não há, por exemplo, dados relativos a custos operacionais, assim como simulações de carregamento e projeções de carga. Mesmo que existissem todos esses dados em detalhe, o Plano discretamente expõe a fragilidade de toda essa especulação sobre as alterações no transporte de cargas no Rio de Janeiro, afirmando que a aplicação de tais dados "não resistem a uma avaliação crítica um pouco mais severa" (PDAM, 2011, p.464).

Desta forma, é muito difícil prever o uso do Arco e do Porto nos próximos anos, assim como os benefícios econômicos para o setor público decorrentes da implantação e operação desses empreendimentos.

Contudo, ainda que para a administração pública os benefícios sejam incertos, um beneficio para a população tem sido intensamente divulgado: a criação de inúmeros empregos para a população da baixada fluminense. 
A criação de empregos é um dos fatores mais utilizados como justificativa de construção da rodovia. Ainda que seus documentos oficiais de planejamento (RIMA, 2007; PDAM 2011) enfatizem outras justificativas mais técnicas do processo de industrialização da RMRJ, as reportagens dos jornais de grande circulação, bem como os meios de comunicação oficiais do governo, quase sempre dão destaque para a criação de emprego. A reportagem a seguir, do Jornal O DIA (2012), por exemplo, destaca os oitocentos mil empregos que supostamente serão criados nos próximos quinze anos.
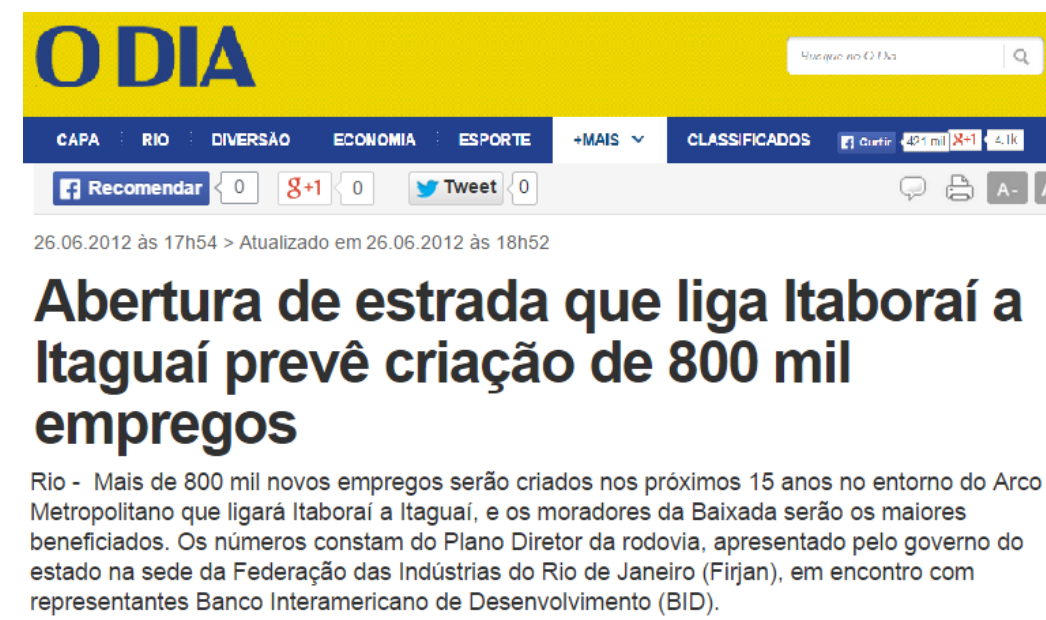

Figura 20 - Reportagem que ressalta os possiveis empregos gerados a partir da construção do ARMJ. Fonte: 0 DIA (2012).

Como vimos no primeiro capítulo, o discurso do aumento da oferta de emprego e a necessidade de industrialização são, há muito tempo, utilizados por projetos desenvolvimentistas e neodesenvolvimentistas. Contudo, autores como Bertucci et al. (2002) acreditam que desenvolvimento industrial, por si só, não possui rebatimento direto em melhoras sociais e nem em alteração do cenário das desigualdade sociais.

Assim, é importante gerar empregos para que não se tenha uma gama de trabalhadores desempregados ou bem educados subempregados, mas é também importante a ampla qualificação da mão de obra para que estes trabalhadores possam atender satisfatoriamente aos cargos criados e tenham uma remuneração adequada. Portanto, para que de fato repercuta em melhorias sociais, o desenvolvimento do setor econômico deve ser acompanhado, entre outros, da maximização da arrecadação tributária e da implementação de programas sociais (SISCÚ; PAULA; MICHEL, 2007). Contudo, no caso do Arco, percebemos que a industrialização e a criação de empregos são vistos como elementos que podem, independente de qualquer outra política publica, gerar bem estar social. 
Esta ideia foi transmitida mais claramente pela presidente da República, Dilma Rousseff, no dia da inauguração do Arco Metropolitano. Em seu discurso, ela declarou duvidar "que tenha um lugar tão adequado para se instalar uma empresa como esse Arco Rodoviário" pouco depois, a presidente prevê que o Arco seria o primeiro passo para melhorias na baixada: "Esta região vai se transformar em uma das regiões mais ricas do estado do Rio de Janeiro. Podem cobrar isso no futuro. Aqui foi dado um passo essencial para gerar emprego de qualidade, para melhorar a vida da população que vive aqui” (SITE DO PLANALTO, 2014 - Grifo nosso).

Com esse tipo de notícia (figura 20) e com essa fala da presidente, se passa a mensagem de que o Arco atrairá empresas $\rightarrow$ essas empresas gerarão empregos e riquezas para a baixada fluminense $\rightarrow$ e estes melhorarão a vida da população que ai vive. Essa é a argumentação utilizada para que a população da baixada acredite que o Arco é uma obra extremamente necessária para que se tenha qualidade de vida. Assim, se vincula uma obra que beneficia empresas privadas à ideia de que isso, na verdade, foi feito para beneficiar a população de forma geral.

Analisando esse desencadeamento de ideias da presidente, notamos que ele está composto de quatro pressupostos essenciais. 0 primeiro que o Arco atrairá empresas. 0 segundo indica que, com estas empresas, a pobre região da Baixada Fluminense vai se tornar uma das mais ricas do Estado fluminense, ascendendo em relação às demais. 0 terceiro expõe que o Arco gerará empregos de qualidade. 0 quarto, assinala que o Arco e estes novos empregos são um passo essencial para melhorar a vida da população da Baixada.

Veremos agora cada um desses tópicos, mais detalhadamente, para mostrar como essa afirmação da presidente faz parte de um discurso ideológico. De acordo com o que colocamos no primeiro capítulo, Marx e Engels (1989) apontam que os discursos ideológicos se baseiam em fatos reais, mas, os distorcem para dar aos interesses de classes da elite uma aparente universalidade, mantendo-se como o defensor do interesse coletivo. Assim, perceberemos aqui esse desencadeamento de ideias segue uma lógica racional que remete à realidade, mas possui falhas, devendo ser, no mínimo, relativizado. Também já explanamos no capítulo inicial que Chauí (1980) aponta que a existência de omissões é fundamental para a sustentação dos discursos ideológicos. Perceberemos aqui que essas omissões objetivam cobrir as falhas que fazem com que fique evidente a inversão da realidade na argumentação ideológica do AMRJ. 


\subsubsection{A atração de empresas}

No início desse capítulo já debatemos um pouco sobre esse primeiro pressuposto. Vimos que não necessariamente uma empresa precisa estar instalada ao longo do Arco para se beneficiar dele. 0 Arco também beneficia empresas que só o utilizarão como rota, como é o caso de empresas do setor logístico, e das empresas de outros estados (como Minas Gerais) que usam o Porto de ltaguaí como forma escoamento da sua produção.

Mas, também comentamos que, de fato, a construção do Arco gerou uma excelente acessibilidade para inúmeros terrenos não edificados da baixada fluminense. Assim, o Arco aumenta a oferta de terrenos para empresas que buscam um local para se instalar. Como diferencial, os terrenos do entorno do Arco possuem fácil acesso às cinco rodovias por ele cortadas e ao Porto de ltaguaí.

Segundo o jornal O FLUMINENSE (2015), a localização estratégica do Arco Metropolitano já está atraindo empresas. Em Seropédica se instalará a multinacional de bens de consumo: Procter \& Gamble (PCtG). Em Duque de Caxias, a multinacional da área de agronegócios e alimentos: Bunge e também uma nova fábrica de refrigerante da CocaCola, cuja previsão é de empregar cerca de 2.200 trabalhadores. Já o município de Queimados abrigará a indústria de biscoitos e massas Piraquê. Segundo a reportagem, a Coca-Cola foi enquadrada no Decreto 39.784, que concede crédito presumido no valor de $6 \%$ do faturamento incremental e a Piraquê foi beneficiada pela Lei 5.636, que reduz o ICMS de 19\% para 2\% e deve gerar 500 empregos (O FLUMINENSE, 2015).

"É evidente que o Arco Metropolitano traz vantagens logísticas espetaculares para o Rio. A obra contribui diretamente para a atração de investimentos importantes para o desenvolvimento da região, ao ligar porto, ferrovia e rodovia. 0 Arco Metropolitano é a nova fronteira de desenvolvimento do Brasil”, disse o secretário de Desenvolvimento Econômico, Julio Bueno (0 FLUMINENSE, 2015).

Como vimos no primeiro capítulo, se essas novas empresas estiverem apenas se mudando de um outro local para o entorno do Arco, haverá somente uma redistribuição regional ou nacional dos empregos. Para o real aumento de empregos no âmbito nacional, o estado do Rio de Janeiro precisaria atrair para o entorno do Arco empresas internacionais, empresas em expansão, ou empresas recém-criadas. É importante perceber que o acontecimento desses últimos dois casos e uma série de outros fatores, tais como: tarifas cobradas; proximidade a matéria prima; custo com mão de obra etc., também influenciam a escolha locacional de uma empresa. Lembramos também que a ideia de instalação de 
empresas ao longo do Arco conta com um cenário de crescimento econômico estadual e nacional e que esse cenário depende de diversos outros fatores, inclusive da conjuntura política internacional.

Contudo, na suas considerações iniciais, o Plano Diretor do Arco Metropolitano do Rio de Janeiro segue uma linha especulativa, que aposta na criação de centenas de milhares de empregos a longo prazo, e afirma tratar-se de um projeto estruturante de grande porte, com grande poder de "multiplicação de fatores de produção, mercados, renda e emprego" (PDAM, 2011, p.3). Admitindo que grande parte dos empregos serão criados a longo prazo, o documento analisa as potencialidades para a instalação de outros tipos de setores industriais, para que seja possível gerar um aumento de empregos mais consistente na área do Arco. Com isso, o aumento significativo de empregos fixos só ocorrerá caso novas empresas se instalem na área.

Nesse contexto, o Plano também mostra acreditar que, no longo prazo, as taxas de desemprego podem cair inclusive nos municípios que não abrigam nenhum dos "empreendimentos aderentes". 0 documento dá como exemplo a cidade de Tanguá, apontando que ela poderá se comportar como um dos vetores de expansão do Arco e do COMPERJ, dada a sua proximidade com o município de ltaboraí. Este argumento se baseia na afirmação de que as obras do COMPERJ já mostram reflexos com relação à oferta de empregos nesse pequeno município de cerca de 30 mil habitantes.

Desta forma, ao mesmo tempo em que esse primeiro item do discurso da presidente está baseado em algo verdadeiro - com o Arco, há um aumento da possibilidade de instalações de empresas na baixada fluminense - ele omite diversos outros aspectos fundamentais para tornar essa possibilidade em algo concreto. Sabemos que a instalação de indústrias na baixada nos próximos quinze anos (que é o horizonte de tempo ao qual se projeta a criação dos oitocentos mil empregos) depende de questões muito mais complexas do que a construção de uma rodovia.

\subsubsection{Enriquecimento da baixada}

Sobre o segundo ponto da fala da presidente, os dados do Produto Interno Bruto (PIB) demonstram que a Região Metropolitana já é a região com maior PIB do Estado do Rio de Janeiro. Contudo, no seu discurso, a presidente se referiu apenas a uma parte da 
RMRJ, que é comumente dividida pela população fluminense em: Baixada Fluminense ${ }^{52}$; Leste Fluminense ${ }^{53}$ e Capital.

Para analisar a riqueza do Estado do Rio de Janeiro, aplicamos essa setorização aos dados do PIB do Estado do Rio de Janeiro (figura 21) ${ }^{54}$. Desta forma, podemos ver que a Baixada Fluminense é a terceira "região" mais rica do Estado sendo responsável por 13,63\% do PIB, perdendo somente para a Capital, e para a Região Norte Fluminense, que produzem respectivamente $39,60 \%$ e $16,06 \%$ do PIB. Vale pontuar que mais de $85 \%$ do PIB da Capital está voltado para o setor de serviços, o que corresponde a 34,20\% do PIB total de todo o estado do Rio de Janeiro. Já na Região Norte Fluminense, 72,76\% do seu PIB é referente ao setor industrial.

\begin{tabular}{|c|c|c|c|c|c|c|c|}
\hline \multirow{3}{*}{ REGIÕES DE GOVERNO } & \multicolumn{6}{|c|}{ VALOR (1000 R\$) } & \multirow{3}{*}{$\begin{array}{c}\text { PIB PER } \\
\text { CAPITA } \\
\text { (R\$) }\end{array}$} \\
\hline & \multicolumn{2}{|c|}{$\begin{array}{l}\text { VALOR ADICIONADO } \\
\text { TOTAL }\end{array}$} & \multicolumn{4}{|c|}{ VALOR ADICIONADO BRUTO POR SETOR } & \\
\hline & BRUTO & $\begin{array}{l}\text { PERCEN- } \\
\text { TUAL } \\
\end{array}$ & $\begin{array}{c}\text { AGROPECUÁ } \\
\text {-RIA }\end{array}$ & INDÚSTRIA & SERVIÇOS (1) & $\begin{array}{l}\text { ADMINISTRA- } \\
\text { ÇÃO PÚBLICA }\end{array}$ & \\
\hline Estado do Rio de Janeiro & 429122945 & & 1859909 & 138131093 & 289131943 & 76932636 & 31065 \\
\hline $\begin{array}{c}\text { Região Metropolitana } \\
\text { RMRJ - Baixada }\end{array}$ & 261090608 & $60,84 \%$ & 197719 & 45759016 & 215133872 & 55131624 & 26946 \\
\hline $\begin{array}{l}\text { Fluminense } \\
\text { RMRJ - Leste }\end{array}$ & 58502807 & $13,63 \%$ & 79049 & 13031484 & 45392274 & 16157805 & \\
\hline $\begin{array}{l}\text { Fluminense } \\
\text { Cidade do Rio de }\end{array}$ & 32657236 & $7,61 \%$ & 55938 & 9631075 & 22970223 & 8387613 & \\
\hline $\begin{array}{l}\text { Janeiro } \\
\text { Região Noroeste }\end{array}$ & 169930564 & $39,60 \%$ & 62732 & 23096457 & 146771375 & 30586207 & 34572 \\
\hline Fluminense & 4360505 & $1,02 \%$ & 223543 & 572875 & 3564086 & 1529474 & 14588 \\
\hline Região Norte Fluminense & 68924055 & $16,06 \%$ & 422543 & 50150957 & 18350555 & 5079075 & 82726 \\
\hline $\begin{array}{l}\text { Região Serrana } \\
\text { Região das Baixadas }\end{array}$ & 16707015 & $3,89 \%$ & 541809 & 4663602 & 11501603 & 3862469 & 22694 \\
\hline Litorâneas & 35812282 & $8,35 \%$ & 135871 & 23467448 & 12208963 & 4337441 & 43884 \\
\hline $\begin{array}{l}\text { Região do Médio Paraíba } \\
\text { Região Centro-Sul }\end{array}$ & 23792884 & $5,54 \%$ & 160413 & 8312966 & 15319505 & 4182372 & 32683 \\
\hline Fluminense & 5641820 & $1,31 \%$ & 129162 & 1690658 & 3821999 & 1343813 & 22890 \\
\hline Região da Costa Verde & 12793777 & $2,98 \%$ & 48848 & 3513571 & 9231358 & 1466368 & 56066 \\
\hline
\end{tabular}

(1) A atividade econômica Serviços inclui a Administração Pública.

Figura 21 - PIB no Estado do Rio de Janeiro em 2012. Fontes: Elaboração própria com dados do Instituto Brasileiro de Geografia e Estatística - IBGE e Fundação Centro Estadual de Estatísticas, Pesquisas e Formação de Servidores Públicos do Rio de Janeiro - CEPERJ (CEPERJ, 2015).

\footnotetext{
${ }^{52}$ Composta pelos municípios de Belford Roxo, Duque de Caxias, Guapimirim, Itaguaí, Japeri, Magé, Mesquita, Nilópolis, Nova lguaçu, Paracambi, Queimados, São João de Meriti e Seropédica.

${ }^{53}$ Composta pelos municípios de ltaboraí, Maricá, São Gonçalo, Niterói e Tanguá.

${ }^{54} \mathrm{Na}$ tabela, os dados são de 2012. Apenas em 2013 os municípios de Cachoeiras de Macacu e Rio Bonito passaram a integrar a RMRJ. Assim, na figura 12, esses municípios ainda faziam parte da Região das Baixadas Litorâneas.
} 
Com isso, acreditamos que dificilmente a Baixada Fluminense cresça o suficiente para ocupar o primeiro lugar desse "ranking". Por outro lado, é razoável pensar que o crescimento industrial da Baixada passará a competir com o Norte Fluminense ${ }^{55}$ pelo setor industrial. Mas, ao analisar essa possibilidade, é necessário observar que mais de 50\% do PIB dessa região vem do setor industrial do município de Campos dos Goytacazes, cuja economia está fortemente vinculada à exploração de petróleo e gás natural por conta da Bacia de Campos. ${ }^{56}$

\subsubsection{A criação de empregos de qualidade}

Sobre o terceiro pressuposto da fala da presidente, qual seja: a criação de empregos de qualidade, é necessário explicar que, ainda que as notícias destaquem a possibilidade de serem criados oitocentos mil empregos nas próximas décadas na Baixada Fluminense (figura 20), esta é apenas uma projeção feita pela FIRJAN (2008). Atualmente, os investimentos do PAC que envolvem o AMRJ e seus empreendimentos aderentes são responsáveis pela criação de apenas setenta e oito mil empregos na fase de obras e de quase onze mil na fase de operação. Assim, mais de oitenta e sete por cento dos empregos criados serão temporários, vinculados apenas às obras, e não à atividade industrial em si. Desta forma, desses oitocentos mil empregos propagandeados, apenas 1,35\% está de fato previsto pela operação dos empreendimentos do PAC.

O PDAM (2011) demonstra preocupação com essa drástica redução da demanda por mão de obra entre a fase de construção e a fase de operação. 0 Plano destaca que projetos dessa magnitude e com esse tipo de distribuição de criação de empregos, costumam criar toda sorte de problemas, uma vez concluída a fase de obras. Grande parte desses problemas derivam da necessidade de "realocação" setorial e/ou espacial da mão de obra empregada durante a primeira fase.

\footnotetext{
${ }^{55}$ Composta pelos municípios de Campos dos Goytacazes, Carapebus, Cardoso Moreira, Conceição de Macabu, Macaé, Quissamã, São Fidélis, São Francisco de Itabapoana e São João da Barra.

${ }^{56} \mathrm{~A}$ Bacia de Campos é a maior província petrolífera do Brasil, responsável por mais de $80 \%$ da produção nacional de petróleo. Ela leva esse nome pela sua proximidade com a cidade de Campos dos Goytacazes, ainda que as atividades de exploração e produção também sejam realizadas próximo a cidades como Macaé, São João da Barra, Quissamã e Carapebus.
} 


\begin{tabular}{|c|c|c|c|}
\hline \multirow{2}{*}{ EMPRENDIMENTO } & \multirow{2}{*}{ LOCAL } & \multicolumn{2}{c|}{ EMPREGOS NA FASE DE: } \\
\cline { 3 - 4 } & & OBRA & OPERAÇÃO \\
\hline COMPLEXO PETROQUÍMICO DO RIO DE JANEIRO & ITABORAÍ / SÃO GONÇALO & 20.000 & 3.500 \\
\hline COMPANHIA SIDERÚRGICA DO ATLÂNTICO (CSA) & SANTA CRUZ - RJ & 18.000 & 3.500 \\
\hline COMPANHIA SIDERURGIA NACIONAL (CSN) & ITAGUAÍ & 18.000 & 3.500 \\
\hline PORTO DE ITAGUAÍ & ITAGUAÍ & 22.000 & 300 \\
\hline \multicolumn{2}{|c|}{ TOTAL } & 78.000 & 10.800 \\
\hline
\end{tabular}

Figura 22 - Empregos previstos pelos investimentos do PAC na RMRJ. Fonte: elaboração própria com base em RIO DE JANEIRO (2011).

No caso do Arco, essa realocação tem dificuldades qualitativas e quantitativas. A fase de operação oferece apenas $14 \%$ da quantidade de empregos oferecidos na fase de obra. 0 obstáculo qualitativo se deve ao fato de que a primeira fase envolve essencialmente atividades de engenharia e construção civil, com predominância da mão de obra típica desses setores. Já a fase seguinte exige mão de obra com qualificação específica, que requer competências diferentes daquelas utilizadas na fase anterior. Com isso, a diferença de salários também é distinta. Os salários médios pagos durante a fase de construção tendem a ser inferiores à remuneração média da mão de obra requerida para a fase de operação (PDAM, 2011). Consequentemente, os empregos temporários criados na fase de construção são para um perfil de trabalhador bem diferente dos empregos da fase de operação. lsto dificulta que um mesmo cidadão consiga converter o emprego inicial da fase de obra em um emprego da fase de operação.

\subsubsection{A criação de empregos e a melhoria da qualidade de vida}

Sobre o quarto pressuposto da fala da presidente, que sustenta que a criação de empregos decorrentes do Arco levará à melhoria da qualidade de vida da população da Baixada, devemos ressaltar dois pontos importantes. 0 primeiro diz respeito ao fato do Arco ser uma obra em área pouco urbanizada. 0 RIMA (2007), por diversas vezes, faz ressalvas a questões vinculadas à saúde do trabalhador. Ele propõe, por exemplo, a priorização da mão de obra local e a capacitação da mesma para a realização dos serviços demandados pelo Arco e pelos empreendimentos estruturantes.

A SEOBRAS (2007) também demonstra que houve inicialmente uma preocupação com a capacitação da mão de obra local. Contudo, a análise de como deveria ser feita a compatibilização entre as necessidades das obras e a realidade/possibilidade das 
comunidades pelas quais o Arco passa deveria ter sido feita no "Plano Diretor Estratégico de Desenvolvimento Sustentável da Meso Região do Arco Metropolitano do Rio de Janeiro", antigo nome dado ao PDAM.

0 estado vem desenvolvendo com os prefeitos da região um Plano Diretor Estratégico de Desenvolvimento Sustentável da Meso Região do Arco Metropolitano do Rio de Janeiro, buscando analisar a melhor integração entre a obra e as comunidades por onde passará. Um dos primeiros assuntos escolhidos é a capacitação de mão de obra para os futuros empreendimentos, de forma que, quando da instalação das empresas, haja profissionais qualificados (SEOBRAS, 2007, p.1).

Essa "função" que deveria ter sido cumprida pelo PDAM é confirmada na apresentação feita por Teixeira (2009), que listou como um dos quatro principais focos do Plano a "capacitação de mão de obra e programa de geração de renda" (TEXEIRA. 2009. Slide 6). 0 relatório do plano apenas repete que essa ação deve ser feita, contudo, não discrimina quem deverá fazer e nem se já foi realizada. Vale lembrar que o último relatório do PDAM só ficou pronto quatro anos após o início da obra.

Assim, o Plano já aponta para o fato que, devido à relativamente longa duração da fase de obras, a mão de obra nela empregada e oriunda de outras localidades acaba desenvolvendo fortes vínculos com a região onde se localiza o empreendimento. Com isso, é comum a busca de soluções das necessidades de moradia e lazer no entorno do local de trabalho. Porém, estas soluções são geralmente feitas de modo informal e por isso podem agravar as questões socioambientais da região.

Essa dinâmica de grande quantidade de oferta de emprego em locais pouco habitados pode resultar em: urbanização não planejada, agravando problemas ambientais; comprometimento da infraestrutura urbana; aumento do subemprego; e crescimento do desemprego da mão de obra e até da criminalidade (PDAM, 2011).

Logo, o supostamente amistoso cenário de concomitância de grandes obras pode acarretar grandes problemas sociais nos municípios que acolheram os trabalhadores da fase de obras. Sendo assim, no curto prazo, o fim da fase de obras pode causar problemas decorrentes da situação de desemprego desse grande número de trabalhadores da construção civil.

Ao comparar os dados do IBGE sobre o padrão educacional da população da RMRJ com os da Região Metropolitana de São Paulo e Belo Horizonte, o Plano expõe que as três regiões possuem aproximadamente um mesmo nível de qualificação. Ao agregar essa 
informação a um cenário de futura melhora logística com os empreendimentos e ainda a uma "política de fomento a encadeamentos", o Plano prevê a geração de empregos concomitantemente a uma melhoria do padrão educacional na área de influência do Arco Metropolitano.

Em alguns trechos do PDAM há a indicação de que o crescimento da oferta de empregos impulsiona uma população com maior poder de compra a "impor a necessidade de mudança na qualidade de atendimento dos serviços públicos” (PDAM, 2011, p. 172). Em outros trechos, o documento demonstra que o aumento da oferta de emprego precisa estar acompanhado de outras políticas públicas para que possa de fato ser fator de melhoria das condições de vida da população. Isso fica claro quando cruzamos os dados de qualidade de vida e de percentual da população empregada no setor industrial, existentes no próprio Plano (figura 23).

\begin{tabular}{|c|c|c|c|c|c|c|c|}
\hline \multirow[t]{2}{*}{ MUNICÍPIOS } & \multirow{2}{*}{$\begin{array}{c}\text { VARIAÇÃO DE } \\
\text { EMPREGOS NA } \\
\text { INDUSTRIA 2000- } \\
2007 \\
\end{array}$} & \multirow[t]{2}{*}{$\begin{array}{l}\text { \% EMPREGOS NA } \\
\text { INDUSTRIA } 2008\end{array}$} & $\begin{array}{c}\text { DEFICIENCIA EM } \\
\text { ILUMINAÇÃO (2000) }\end{array}$ & $\begin{array}{c}\text { DEFICIENCIA EM } \\
\text { PAVIMENTAÇÃO } \\
\text { (2000) }\end{array}$ & $\begin{array}{l}\text { DEFICIENCIA EM } \\
\text { COLETA UXX } \\
(2000)\end{array}$ & $\begin{array}{c}\text { IFDM/ SAÚDE } \\
2006\end{array}$ & IDEB 2007 \\
\hline & & & \multicolumn{5}{|c|}{ POSIÇÃO NO RANKING DE MUNICÍPIOS EM REGIOES METROPOLITANAS* } \\
\hline ITAGUAI ** & 39,74 & 8,9 & - & - & - & 41 & 45 \\
\hline MANGARATIBA ** & $-84,32$ & 0,26 & - & - & - & 37 & 40 \\
\hline SEROPÉDICA & 87,88 & 14,94 & 41 & 50 & 47 & 35 & 55 \\
\hline BELFORD ROXO & 30,88 & 10,43 & 20 & 42 & 40 & 59 & 56 \\
\hline DUQUE DE CAXIAS & 48,02 & 17,96 & 27 & 34 & 37 & 47 & 52 \\
\hline JAPERI & 175,97 & 12 & 51 & 54 & 54 & 54 & 53 \\
\hline MAGÉ & $-6,84$ & 17,68 & 47 & 43 & 45 & 49 & 54 \\
\hline MESQUITA & - & 11,03 & 22 & 35 & 42 & 45 & 49 \\
\hline NILÓPOLIS & 109,5 & 7,32 & 2 & 3 & 10 & 43 & 44 \\
\hline NOVA IGUAÇU & $-2,07$ & 15,17 & 19 & 16 & 35 & 15 & 23 \\
\hline PARACAMBI & $-86,55$ & 10,24 & 29 & 40 & 43 & 55 & 46 \\
\hline QUEIMADOS & 30,12 & 23,5 & 37 & 51 & 44 & 58 & 50 \\
\hline SÃO JOÃO DE MERITI & 45,7 & 10,23 & 5 & 27 & 18 & 56 & 58 \\
\hline CACHOEIRAS DE MACACU & 27,89 & 15,41 & - & - & - & 39 & 43 \\
\hline GUAPIMIRIM & 6,21 & 15,65 & 49 & 38 & 50 & 52 & 57 \\
\hline ITABORAÍ & 53,79 & 18,11 & 54 & 52 & 53 & 53 & 48 \\
\hline MARICÁ ** & 160,44 & 11,82 & - & - & - & 42 & 34 \\
\hline NITERÓl & 110,2 & 9,71 & 16 & 14 & 22 & 7 & 38 \\
\hline SÃO GONÇALO & 20,59 & 6,92 & 42 & 39 & 33 & 20 & 47 \\
\hline TANGUÁ & 70,16 & 15,43 & 53 & 55 & 51 & 57 & 51 \\
\hline
\end{tabular}

* Onde foram computados municípios da região metropolitana de São Paulo, Belo Horizonte e Rio de Janeiro. Quanto maior é a colocação do município no Ranking pior é sua situação na determinda categoria

** Nas tabelas do Plano Diretor do Arco Metropolitano não constam a posição destes municípios quanto a infraestrutura básica.

Figura 23 - Qualidade de vida X empregos na indústria. Fonte: Elaboração própria com base em dados do Plano Diretor do Arco Metropolitano (2011).

Tais dados apontam que não é possível fazer uma ligação entre percentual de emprego na indústria e o desenvolvimento social ou benefícios para a população. Inclusive, em alguns casos, os municípios que possuem os maiores índices de emprego no setor industrial são justamente os que possuem os piores índices de qualidade de vida. Na figura a seguir, notamos, por exemplo, que ltaboraí e Tanguá têm altos índices de população 
trabalhando no setor industrial e, ainda assim, ocupam posições nos rankings que demonstram as péssimas condições de pavimentação, iluminação, coleta de lixo e saúde destas cidades.

Um estudo sobre desenvolvimento da Federação das Indústrias do Rio de Janeiro (FIRJAN) também confirma essa impossibilidade de atrelar emprego a indicadores de qualidade de vida como saúde e educação. 0 Índice FIRJAN de Desenvolvimento Municipal $(\text { IFDM })^{57}$ mostram que um município pode ter um bom índice de saúde, sem necessariamente ter um bom índice no quesito emprego e renda, como é o caso dos municípios de Magé e Guapimirim. 0 estado de São Paulo, por exemplo, recebeu da FIRJAN índice de saúde e educação consideravelmente melhores do que o estado do Rio de Janeiro, enquanto possui um índice de emprego e renda bem parecido (ver figura 24).

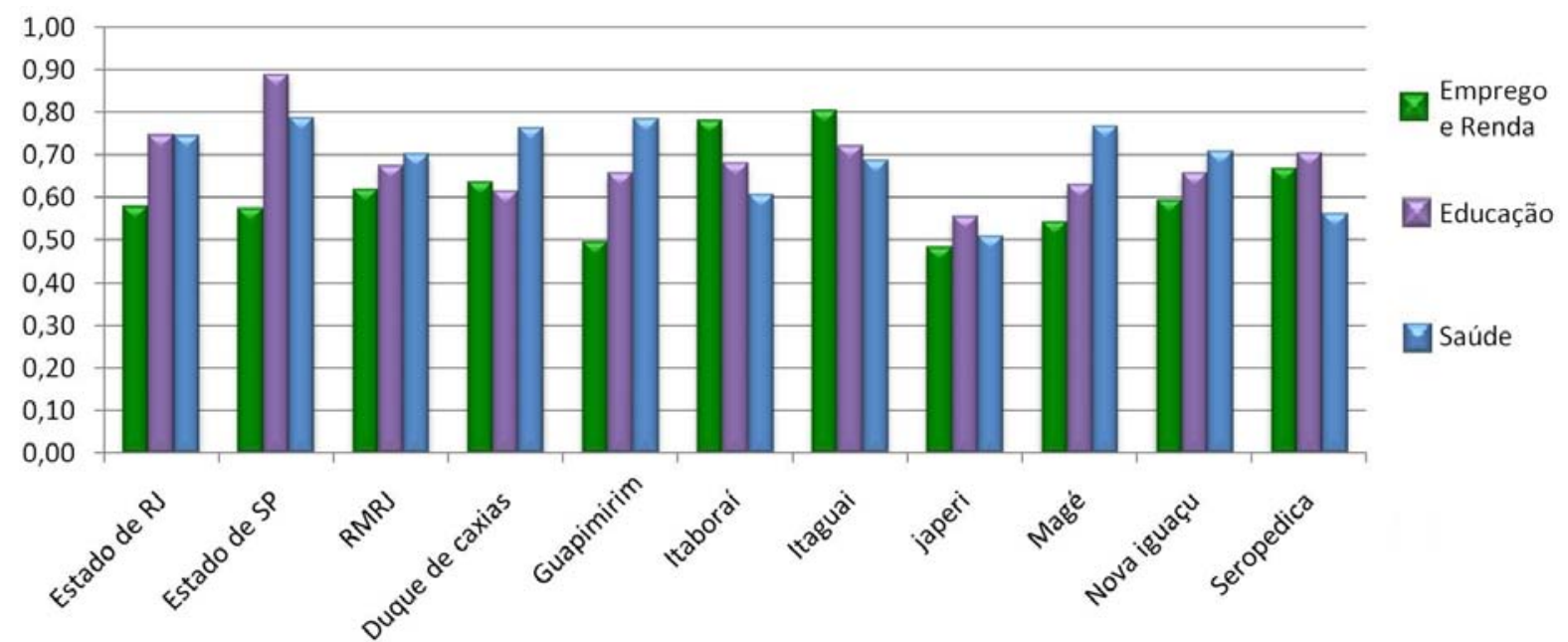

Figura 24 - Índice FIRJAN de Desenvolvimento Municipal das cidades cortados pelo AMRJ. Fonte: IFDM (2011).

Como vimos, por vezes as "propagandas" do Arco exibem o aumento de emprego como algo benéfico, sem questionar a relação desse tipo de emprego (condições de trabalho, salários, etc.) com os indicadores sociais e com os índices de qualidade de vida da população.

Pelo exposto, notamos que a argumentação da geração de empregos se encaixa perfeitamente na descrição de ideologia conforme Marx e Engels (1989) e Chauí (1980). Todos os pontos da argumentação que levam à conclusão de que o Arco gera o aumento de

57 O Índice FIRJAN de Desenvolvimento Municipal é um estudo do Sistema FIRJAN que acompanha anualmente o desenvolvimento socioeconômico de todos os mais de 5 mil municípios brasileiros em três áreas de atuação: Emprego e renda, Educação e Saúde. Criado em 2008, ele é feito, exclusivamente, com base em estatísticas públicas oficiais, disponibilizadas pelos ministérios do Trabalho, Educação e Saúde. Fonte: www.firjan.org.br/ifdm. Ultimo acesso em janeiro de 2015. 
emprego tem vinculações com fatos reais mas, em geral, se baseiam apenas em especulações. Para a concretização dessas especulações seriam cruciais uma série de outros fatores que por vezes são omitidos.

Além disso, os índices mostram que não se pode fazer uma relação direta entre quantidade de emprego e qualidade de vida. A questão da qualidade de vida envolve inúmeros outras itens além da questão da renda. No caso do Arco, pode vir a acontecer até o contrário: a diferença entre a quantidade e o tipo de empregos na fase de obras e na fase de operação levanta a possibilidade de que isso cause o agravamento dos problemas relacionados à qualidade de vida, e não a melhora dos mesmos.

Ademais, ainda que o PDAM (2011) ocupe a maior parte das suas páginas, enumerando as vantagens econômicas do Arco, em alguns momentos ele lembra dos prováveis impactos negativos que serão gerados com a implantação do Arco que tem rebatimento na qualidade de vida da população, citando, entre outros: conflitos fundiários, subemprego, pobreza, criminalidade e insuficiência de infraestrutura básica.

\subsection{Estruturação do território}

Como citamos no início desse capítulo, entendemos que o Arco Metropolitano, como toda nova via de uma malha rodoviária, tem grande validade para estruturação do território metropolitano e aumenta a conectividade entre as vias existentes ao criar uma nova opção de rota.

Ao quadriplicar a quantidade de vias de acesso à região portuária de Itaguaí, o Arco facilita o acesso de mercadoria ao porto e colabora com a diminuição dos custos de transporte que incide sobre produtos importados e exportados. Não há dúvidas que redução desses custos é uma medida importante para a relação comercial internacional. Contudo, a questão que colocamos é: frente a um grave problema de mobilidade metropolitana o Arco era uma obra prioritária para a população da Baixada?

Veremos que o AMRJ não só não era prioritário para a população da Baixada como também não foi construído com o intuito de mitigar os problemas de mobilidade desta. No entanto, uma vez que ele já foi construído para atender às necessidades de outros setores da sociedade, acreditamos que esta nova rodovia poderá vir a facilitar de alguma forma a 
mobilidade da RMRJ. Afinal, em um país com forte opção rodoviária como o nosso, uma nova via dificilmente será inútil. Assim, reiteramos que não estamos aqui discutindo a utilidade do Arco e sim a relação custo/benefício dele para os diferentes setores da sociedade. A quem ele mais beneficia? A quem ele mais prejudica? Fazemos uma análise do uso da ideologia no discurso de defesa do Arco para entender como as classes que se beneficiam com ele conseguem argumentar de forma a convencer as classes prejudicadas que o saldo dessa relação custo/benefício é positivo para todos. Assim, focamos na análise das justificativas do Arco, presentes nas suas principais fontes governamentais de informação.

Há uma justificativa que afirma que o Arco foi realizado com intuito de "aumentar os níveis de acessibilidade dos municípios próximos ao Arco e que concentram grande contingente populacional" (PDAM, 2011). Essa justificativa está perfeitamente correta. Contudo ela foi escrita, no mínimo, de uma forma curiosa. É evidente que Arco aumenta a conectividade dos municípios cortados por ele. Também não está errado dizer que tais municípios possuem grande contingente populacional. 0 curioso dessa frase é que essas duas verdades, quando juntas em uma mesma sentença, induzem um leitor leigo a concluir que o Arco beneficiará diretamente a esse grande contingente populacional, criando uma melhor mobilidade para ele. No entanto, essa "entrelinha" não é verdadeira. 0 AMRJ passa em áreas pouco populosas desses municípios, muitas vezes em locais que hoje são ocupados por pastos e até florestas.

Percebemos então, como o discurso do Arco é montado de forma estratégica, com frases construídas com o intuito ideológico de que a população acredite que esta obra the trará benefícios diretos no que tange à mobilidade urbana. Nesse tópico, analisaremos mais a fundo duas outras justificativas que dizem respeito à estruturação do território. A primeira aponta que o Arco se faz necessário para evitar a entrada desnecessária de veículos que estejam somente de passagem pela cidade do Rio de Janeiro, diminuindo assim os engarrafamentos na Ponte Rio-Niterói (BR-101), na Avenida Brasil e na BR-101 (entre Manilha e Ponte) (PDAM, 2011; RIMA, 2007). A segunda aponta que o Arco se faz necessário para Introduzir novas possibilidades de expansão urbana para os municípios localizados próximos à rodovia (RIMA, 2007). 


\subsubsection{Mobilidade da RMRJ e a melhora do tráfego nas grandes vias}

Um argumento frequentemente usado para justificar a implantação do Arco Metropolitano é o suposto desvio de tráfego de veículos comerciais de longa distância que a rodovia geraria, "aliviando os principais corredores metropolitanos, tais como a Avenida Brasil, Ponte Rio-Niterói, BR-101 (entre Manilha ${ }^{58}$ e Ponte)” (RIMA, 2007, p.7). Para o Plano do Arco, a rodovia tem três funções básicas. A primeira é a ligação entre o COMPERJ e o Porto de ltaguaí que já discutimos acima. A segunda é esse alívio do trânsito na Avenida Brasil e na Ponte Rio- Niterói e a terceira é o aumento de acessibilidade dos municípios cortados pelo Arco, beneficiando assim o grande contingente populacional que ali vive.

Esse argumento da melhoria da mobilidade urbana da RMRJ foi amplamente difundido. No blog oficial do Palácio do Planalto há uma postagem exclusiva sobre esse tema cuja manchete destaca: "Arco Metropolitano diminuirá tráfego nas principais vias do Rio de Janeiro". Nele, há um vídeo no qual o Superintendente do DNIT, Antônio Fernando Guanabarino, afirma que o Arco representa "um ganho na mobilidade urbana muito grande", "eliminando o tráfego pesado ao longo da Avenida Brasil", tendo inclusive "reflexos positivos na ponte Rio-Niterói” (BLOG DO PLANALTO, 2014).

No seu discurso de inauguração do Arco, a Presidente Dilma Rousseff pontuou que, ao tirar o tráfego pesado de dentro dos grandes centros urbanos, o AMRJ está preservando a vida. Primeiro, porque garante segurança, já que o tráfego pesado sempre causa acidentes e "acidentes causam mortes e nós sabemos que morte no trânsito é uma das principais causas de morte no nosso país". E, em segundo lugar, porque proporciona para os motoristas ”tempo de vida para você passar com seus filhos" (SITE DO PLANALTO, 2014).

Contudo, veremos nesse tópico que este argumento de melhoria da mobilidade para população da RMRJ é um discurso ideológico. Tal característica fica clara quando observamos que este discurso: a) parte de um argumento vago, mas verdadeiro: a criação de uma nova via pode aliviar, ainda que minimamente, o fluxo de veículos de outras vias existentes; b) transpõe essa verdade para um caso de grande apelo popular: a melhoria da mobilidade nas vias com maiores problemas de trânsito da cidade; c) afirma algo que não pode ser testado, uma vez que não há dados sobre a quantidade de veículos que deixarão de usar essas vias existentes após a construção da nova via. Dito isso, apontaremos aqui

\footnotetext{
${ }^{58}$ Manilha é um bairro do município de ltaboraí no qual se dá o cruzamento da rodovia BR-101 com as estradas BR-493 e RJ-104.
} 
alguns dados concretos sobre a construção ideológica por trás do argumento de justificativa do Arco como via que melhoraria o tráfego na Ponte Rio-Niterói e na Avenida Brasil, que dá acesso aos municípios da Baixada.

Para começar, lembramos que nos últimos anos a população da RMRJ vem reclamando dos aumentos de tarifas, da má qualidade nos serviços e do aumento do tempo gasto no deslocamento. Neste último item, pesquisas recentes apontam que a região metropolitana fluminense tem o maior porcentual de população que gasta mais de uma hora por dia no trajeto casa-trabalho (Figura 25), superando inclusive a região metropolitana paulista, famosa pelos engarrafamentos.

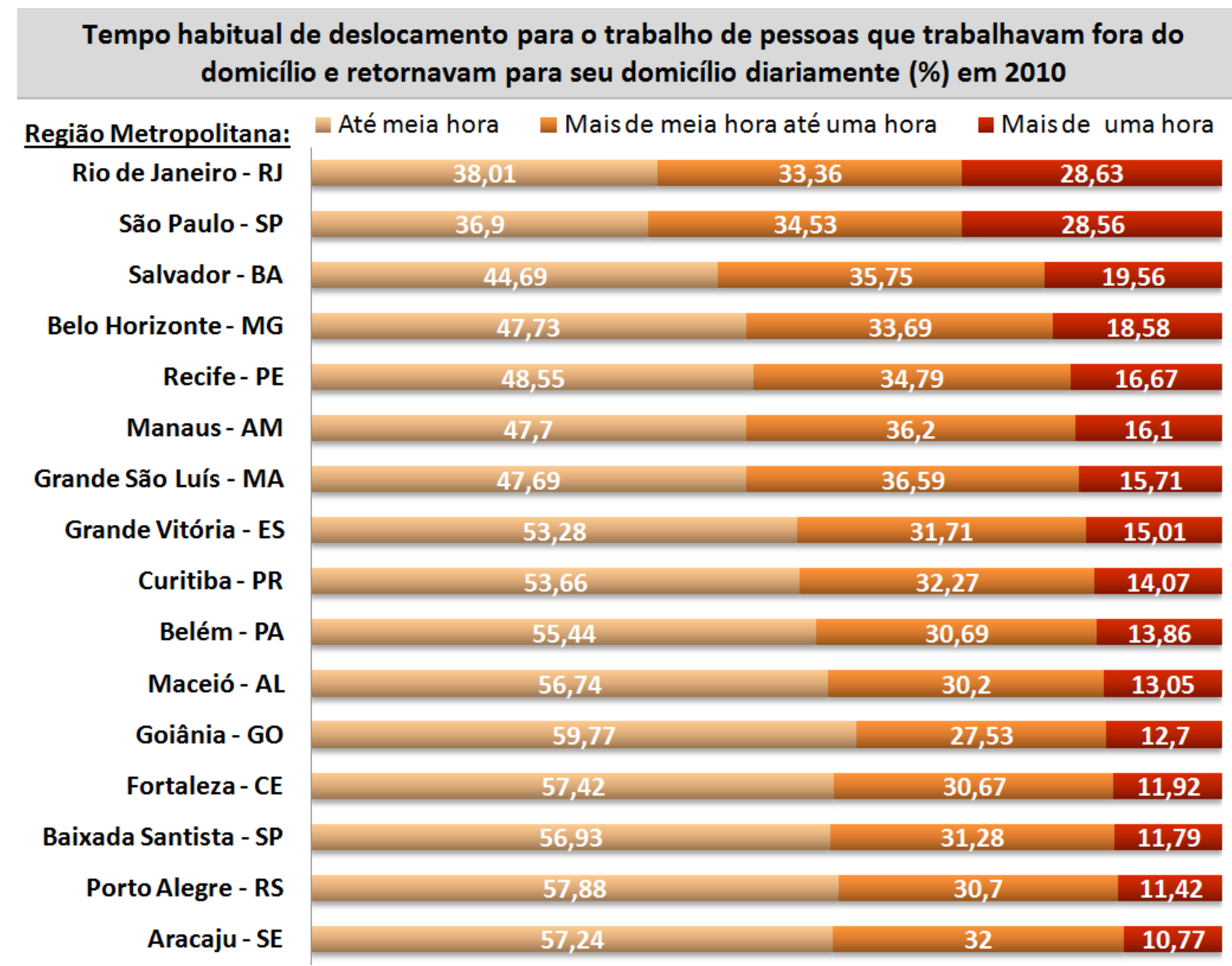

Figura 25 - Fonte: Elaboração própria com base no Censo Demográfico de 2010 (dados da amostra), (SITE DO IBGE, 2010).

Já em relação ao valor das tarifas, no início de 2012, com a proposta de aumento superior a $60 \%$ do valor da tarifa das barcas que cruzam a baía de Guanabara (meio de transporte fundamental para quem realiza o trajeto Rio-Niterói), tornaram-se cada vez mais frequentes as manifestações por melhorias no serviço e pela diminuição do tempo entre as 
embarcações. Para o passageiro que tem o Bilhete Único Intermunicipal o ajuste foi mais suave, cerca de $11 \%$.

Em 2013 uma reportagem mostrou que os preços cobrados pela concessionária CCR Barcas são superiores ao do East River, em Nova York, ou da Baía de Nápoles, na ltália. A matéria ironiza comentando que aqui paga-se tarifa igual superior ao serviços de sonho do primeiro mundo, mas 95 mil passageiros vive diariamente o pesadelo da travessia marítima entre as duas cidades.

Quem ia do centro do Rio de Janeiro para a o centro de Niterói pagava em 2013 R\$ 0,90 por quilômetro, para ir a Charitas, nos catamarãs este custo subia para $\mathrm{R} \$ 1,47$. Na mesma época, o custo por quilômetro da linha nova-iorquina que liga Wall Street (sala de estar do capitalismo mundial) a long lsland, custa $\mathrm{R} \$ 0,57$ por quilômetro para quem dispõe do passe mensal, que dá direito a viagens ilimitadas. Na ltália, esse custo varia de $R \$$ 0,68 a $R \$ 1,30$ na viagem que liga a llha de Capri (um dos destinos turísticos mais famosos da Europa) à de Nápoles. Comparando com a realidade brasileira, a disparidade do custo fluminense é ainda maior, "A viagem de Belém ao Arquipélago de Marajó, no Pará, é 16,6 vezes mais longa, mas sai por $\mathrm{R} \$ 0,19$ por quilômetro ou a $\mathrm{R} \$ 0,26$, com ar-condicionado" (DIAS, 2013).

\section{Manifestação contra aumento das barcas é mantida}

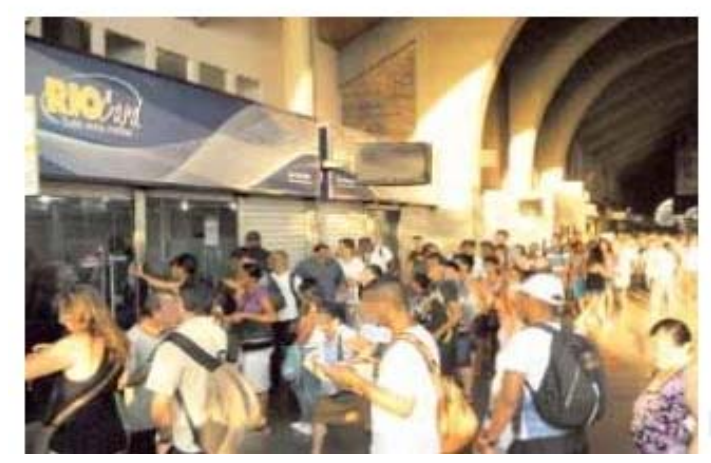

Por: Aline Balbino, Bianca Lopes e Rafael Lopes Tamanho da fonte: A- A+ $29 / 02 / 2012$

Reajuste de $\mathrm{R} \$ 2,80$ para $\mathrm{R} \$ 4,50$, que entra em vigor no sábado na travessia RioNiterói, revoltou usuários que reclamam também da qualidade do serviço prestado pela concessionária

Figura 26 - Manchete sobre manifestações contra o aumento da tarifa das barcas no Rio de Janeiro. Fonte: JORNAL O FLUMINENSE, 29/02/2012.

Ainda em relação à qualidade do serviço do transporte intermunicipal, as linhas de trem que ligam o centro da capital fluminense aos municípios periféricos apresentam inúmeros problemas que geram revolta nos passageiros. Além da superlotação, os usuários, que são grande parte dos moradores da RMRJ, sofrem diariamente com o sucateamento desse modal fundamental para realizar o trajeto casa-trabalho de grande parte da população fluminense. Um caso emblemático ocorreu em setembro de 2013. Após semanas 
de sucessivos problemas na Supervia (concessionária que opera os trens no Rio de Janeiro), no dia três de setembro de 2013, passageiros protestaram nos trilhos e as vinte e sete estações precisaram ser fechadas. No dia onze do mesmo mês, uma nova pane causou tumulto nas estações de Triagem e da Central, fazendo com que passageiros revoltados colocassem fogo em um trem na estação Bonsucesso $(G 1,2013)$.

Assim, com foco nos problemas de mobilidade da RMRJ, em junho de 2013 iniciouse uma série de manifestações cujo estopim foi o reajuste da tarifa de ônibus. A população fluminense passou a se expressar mais contundentemente, expondo uma verdadeira crise que atinge todos os modais do transporte público. Uma das manifestações contra o aumento da passagem reuniu mais de um milhão de pessoas na principal via do Centro da cidade do Rio de Janeiro (figura 27).

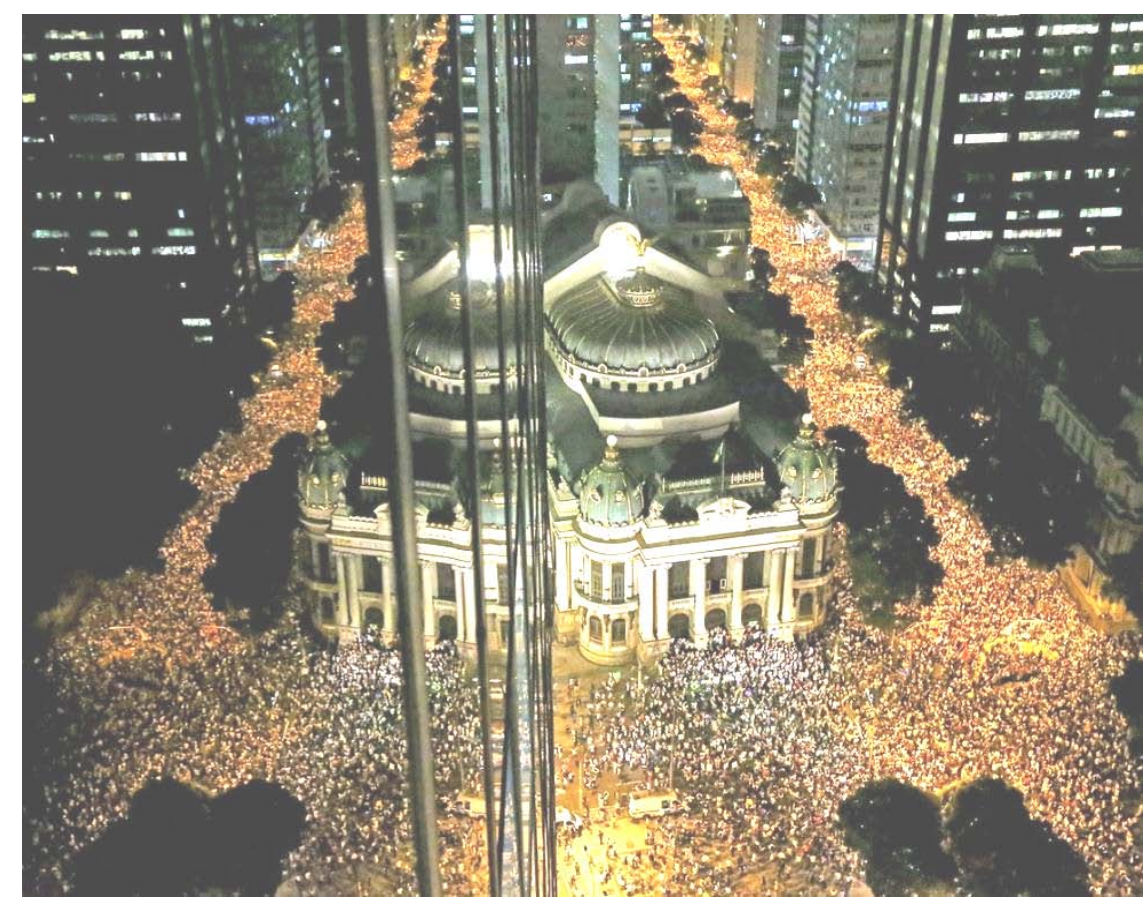

Figura 27 - Manifestação em junho de 2013 no centro do Rio de Janeiro. Foto de: Fabio Motta (Jornal Estado de São Paulo, 2013)

Como resultado dessas manifestações, foi criada em agosto de 2013 a "CPl dos ônibus"na Câmara de Vereadores do Rio de Janeiro. Essa Comissão Parlamentar de Inquérito (CPI) teria como objetivo investigar o setor de transporte público viário, representando assim, uma primeira tomada de decisão rumo à solução da questão da mobilidade metropolitana. Entretanto, a composição da comissão gerou uma nova polêmica, pois quatro $^{59}$ dos os cinco integrantes da Comissão faziam parte da base aliada do prefeito e do

\footnotetext{
${ }^{59}$ Chiquinho Brazão (PMDB), Professor Uóston (PMDB), Jorginho da SOS (PMDB) e Renato Moura (PTC).
} 
governador. Além disso, a princípio, estes quatro vereadores se recusaram a assinar o pedido de instalação da CPI e só o assinaram quando este já tinha atingido o número mínimo de assinaturas necessárias para a criação da comissão. Esses fatos provocaram dúvidas sobre a validade da CPI.

Mentor da proposta de criação da CPI e único parlamentar da oposição ao prefeito e ao governador a integrar a comissão, o vereador Eliomar Coelho, do PSOL, decidiu renunciar à condição de membro da CPI dos Ônibus por discordar da legitimidade da composição da comissão considerando-a incorreta e imoral. Entre agosto de 2013 e o início de 2015 o funcionamento da CPI dos ônibus foi alvo de recorrentes disputas judiciais. A questão central sempre é a legitimidade de composição da Comissão.

0 vereador Eliomar Coelho disse que deixou a vaga por não reconhecer a legitimidade da CPI. "Não reconhecemos legitimidade nos membros da comissão que lá estão. Além disso, não tem a menor condição de falar de uma coisa ilegítima proporcionada por eles. Eu sou membro nato, tudo que está sendo decidido e resolvido é sem a minha pessoa. Não vou contribuir para isso. Eu acho incorreto e imoral", alegou (AGÊNCIA BRASIL, 2013).

Nesse cenário, percebemos assim, que a crise de mobilidade urbana da RMRJ é bastante complexa e atinge diversos modais. Embora o Arco seja exposto como uma obra que visa melhorar o fluxo metropolitano fluminense, até o Plano Diretor dele faz algumas ressalvas sobre este tema. Em determinados trechos, o PDAM faz forte crítica ao uso do modal viário. Ele aponta que a preferência dada ao transporte rodoviário sobre a alternativa ferroviária gerou a desativação de diversos ramais ferroviários. Estas ferrovias seriam hoje de grande importância funcional para racionalizar o sistema de circulação na metrópole (PDAM, 2011).

Já sobre o sistema metroviário, o plano reforça o pensamento aparentemente unânime entre os especialistas de transporte de que a malha atual do Rio de Janeiro é irrisória frente à sua grande potencialidade. Sobre o sistema aquaviário, o Plano apenas cita os problemas relacionados à não implantação das novas ligações previstas na alteração de concessão ocorrida em 1998. Além disso, o plano ainda lembra que, em comparação com os demais modais, o meio rodoviário é o de menor eficiência energética, o que mais consome combustível e o que mais emite poluentes na camada atmosférica (figura 28). 

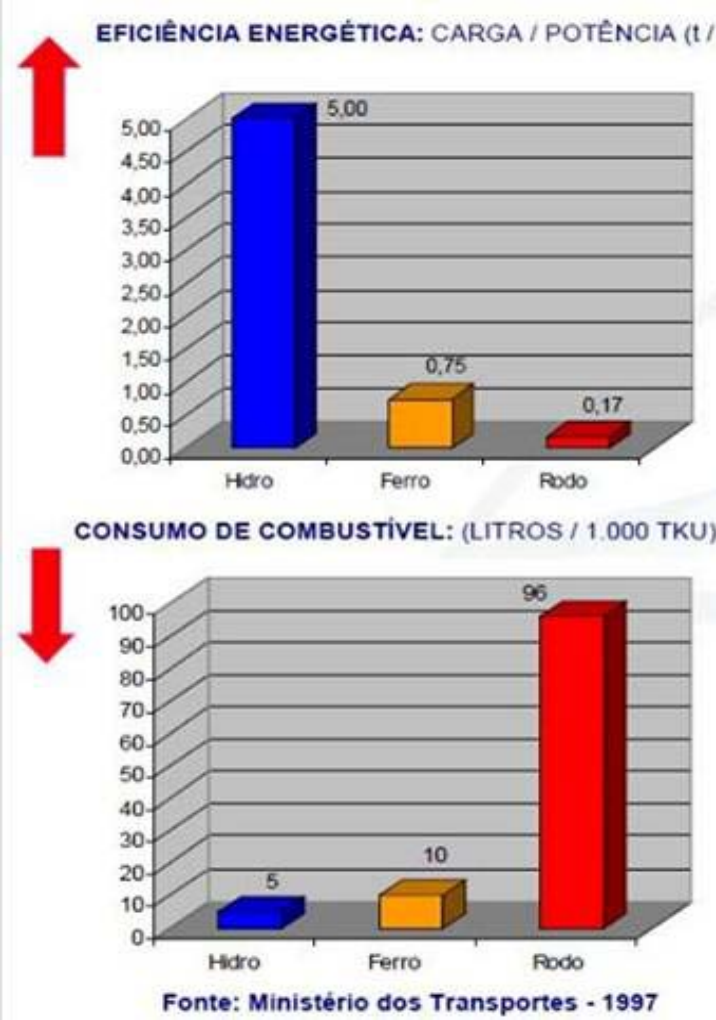
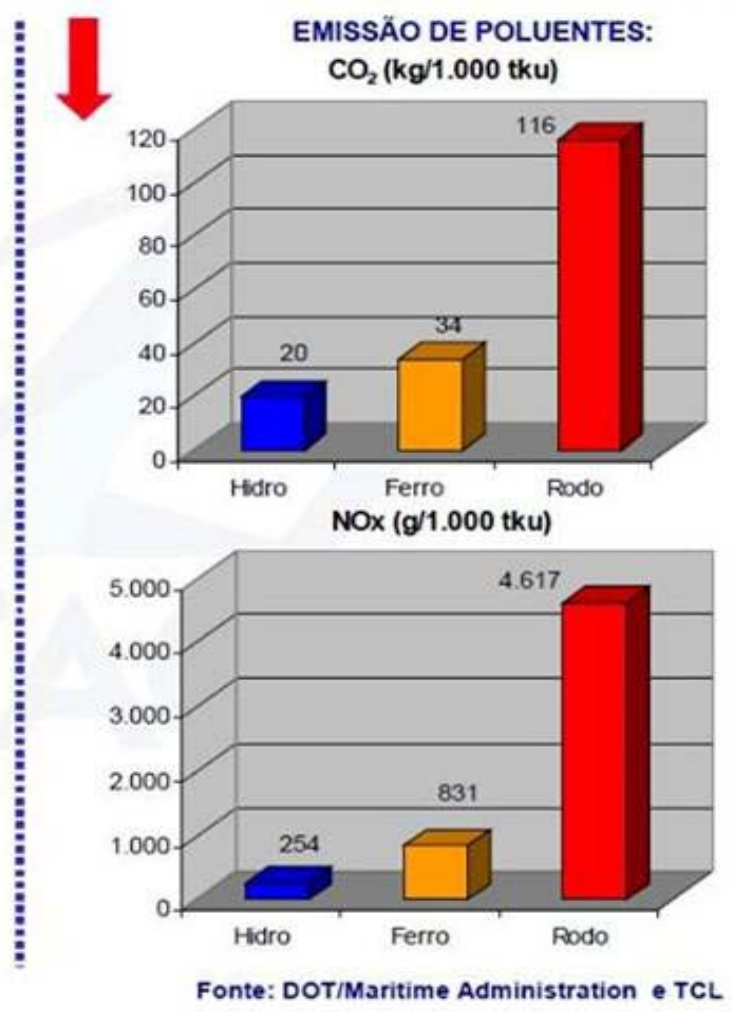

Figura 28 - Aspectos Ambientais dos meios de transporte. Fonte: Agência Nacional de Transportes Aquaviários in PDAM,2011, p.226.

No mapa de carregamento dos eixos de transporte da RMRJ (figura 29) apresentado no PDAM observa-se claramente a alta densidade de fluxos entre a área central do município do Rio de Janeiro e seu acesso à Zona Sul e à Zona Norte da cidade; a Niterói e aos principais municípios da Baixada Fluminense (Duque de Caxias, Nova lguaçu, São João de Meriti, Nilópolis, Belford Roxo e Mesquita). Nota-se também que o Arco passa à margem desse fluxo intenso, conectando duas áreas de baixo fluxo - Itaboraí a Itaguaí, sem, aparentemente, intervir no atual carregamento dos principais eixos de transporte da RMRJ.

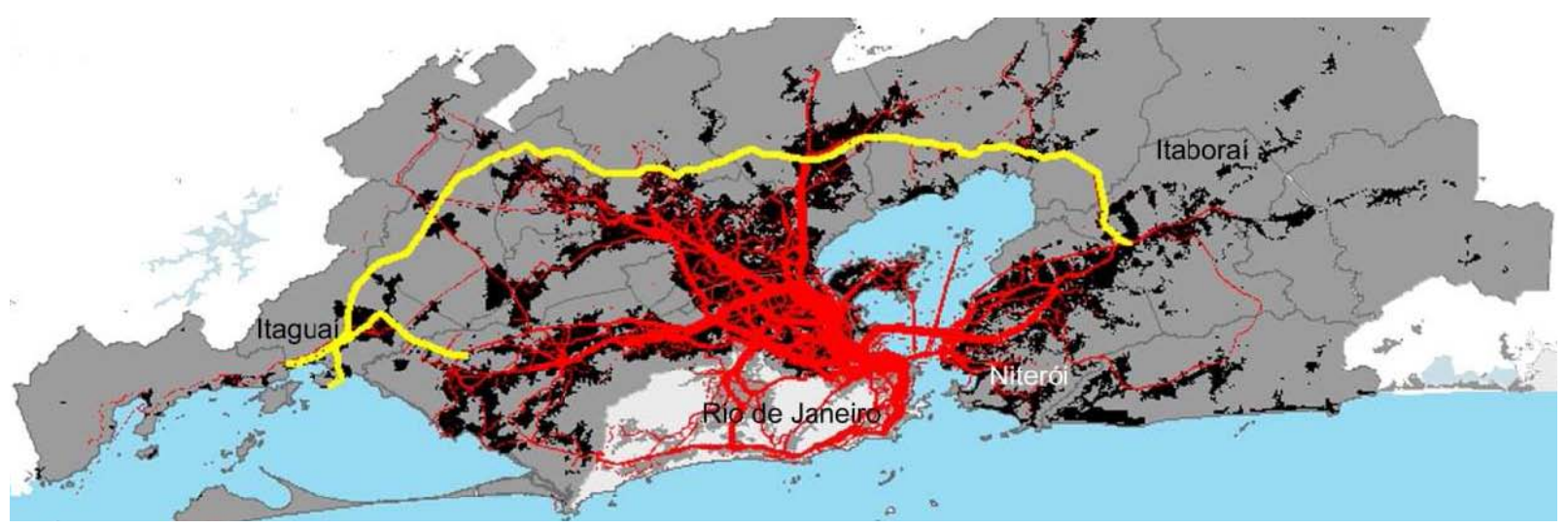

Figura 29 - Carregamento atual dos eixos de transporte da RMRJ. Fonte: PDAM (2011). P.457 
Também cabe lembrar que o Arco é uma rodovia voltada para o transporte de cargas, e não de pessoas. Atualmente, na RMRJ o transporte de carga significa cerca de 1\% das viagens motorizadas, conforme dados (figura 30) do Plano Diretor de Transporte Urbano da Região Metropolitana do Rio de Janeiro (PDTU-RMRJ) de 2010. Deste 1\%, o Arco beneficia apenas os transportes de cargas cuja origem e/ou destino não são a capital, nem Niterói, mas que hoje precisam atravessar trechos desses dois municípios no seu trajeto, o que acaba piorando o já colapsado sistema viário da capital e seus acessos.

\begin{tabular}{c|l|r|r}
\hline \multicolumn{2}{|l|}{ Modo de transporte } & \multicolumn{1}{c}{$\begin{array}{c}\text { Viagens } \\
\text { realizadas }\end{array}$} & $\%$ \\
\hline \multirow{4}{*}{$\begin{array}{c}\text { Transporte } \\
\text { individual }\end{array}$} & Condutor de auto & 2.106 .591 & $64 \%$ \\
\cline { 2 - 4 } & Passageiro de auto & 863.043 & $26 \%$ \\
\cline { 2 - 4 } & Táxi & 139.109 & $4 \%$ \\
\cline { 2 - 4 } & Motocicleta & 100.922 & $3 \%$ \\
\cline { 2 - 4 } & Caminhão & 29.448 & $1 \%$ \\
\hline Total modo individual & & 3.239 .113 & $100 \%$ \\
\hline \multirow{4}{*}{ Transporte coletivo } & 5.302 .081 & $57 \%$ \\
\cline { 2 - 4 } & Ornibus municipal & 1.331 .894 & $14 \%$ \\
\cline { 2 - 4 } & Ornibus intermunicipal & 1.630 .985 & $18 \%$ \\
\cline { 2 - 4 } & Transporte alternativo & 355.404 & $4 \%$ \\
\cline { 2 - 4 } & Metrô & 303.578 & $3 \%$ \\
\cline { 2 - 4 } & Transporte escolar & 190.262 & $2 \%$ \\
\cline { 2 - 4 } & Transporte fretado & 92.150 & $1 \%$ \\
\cline { 2 - 4 } & Barco/Aerobarco / & 82.091 & $1 \%$ \\
\hline & Catamarã & 2.195 & $0 \%$ \\
\cline { 2 - 4 } & Bonde & 9.290 .640 & $100 \%$ \\
\hline
\end{tabular}

Figura 30 - Divisão modal das viagens motorizadas da RMRJ. Fonte: PDTU da RMRJ (2010).

Além disso, cabe ressaltar que a ponte Rio-Niterói ${ }^{60}$, a Avenida Brasil ${ }^{61}$ e mais de trinta diferentes vias estruturantes da cidade ${ }^{62}$ já possuem restrições a transporte de carga nos horários de grande e médio fluxo de veículos. Sendo assim, o Arco Metropolitano não tem impacto sobre os horários de pico de fluxo de veículos de transporte de passageiro, pelo simples fato de os problemas atuais de mobilidade dessas vias não serem essencialmente

\footnotetext{
${ }^{60}$ Segundo informações do site oficial da ponte Rio-Niterói (http://www.ponte.com.br), caminhões e carretas acima de dois eixos (com três eixos ou mais) podem atravessar a Ponte somente no horário das $22 \mathrm{~h}$ às $4 \mathrm{~h}$. A restrição vale para todos os dias (úteis, finais de semana e feriados) e para os dois sentidos de direção da rodovia. Para caminhões com até dois eixos é somente proibida a passagem na pista sentido Rio de Janeiro entre $4 \mathrm{~h}$ e $10 \mathrm{~h}$.

${ }^{61}$ Segundo resolução lançada no dia 12/06/12 pela Secretaria municipal de Transportes do Rio de Janeiro, a circulação de veículos de transporte de cargas especiais e dimensões que precisam de Autorização Especial de Trânsito (AET) está restrita na Avenida Brasil ao horário de $23 \mathrm{~h}$ às $5 \mathrm{~h}$. Nessa exigência são enquadrados os veículos com características que excedam limites dimensionais de: 30 metros de comprimento, 3,20 metros de largura e 4,70 metros de altura e/ou que excedam o peso bruto de 57 toneladas.

${ }^{62}$ Conforme decreto 29.231 de 24/04/2008 que proíbe o tráfego de caminhões de segunda a sexta-feira nos periodos entre $6 \mathrm{~h}$ as $10 \mathrm{~h}$ e $17 \mathrm{~h}$ e $20 \mathrm{~h}$.
} 
gerados pelo transporte de cargas. Desta forma, podemos dizer que o AMRJ é uma via que praticamente beneficia apenas ao transporte de cargas, inclusive por não ter nenhuma restrição de horário e por favorecer a conexão entre as principais estradas da RMRJ e o acesso a rodovias federais.

Mais recentemente, no carnaval de 2015 foi noticiado que algumas linhas de ônibus de viagem utilizariam o Arco. Devido ao grande fluxo de veículos em direção a Região dos Lagos, o que comumente ocorre nesse feriado, duas empresas de ônibus intermunicipais passaram pela primeira vez pelo Arco Metropolitano. Usando o trecho do Arco que havia sido duplicado há alguns anos, foi feita uma nova rota para os passageiros que embarcaram em Nilópolis e no centro do Rio de Janeiro, evitando assim a ponte Rio-Niterói e a NiteróiManilha. Os passageiros que embarcaram em Campo Grande e Nova Iguaçu, utilizaram o novo trecho do Arco Metropolitano. Além de evitar a ponte Rio-Niterói e a Niterói-Manilha, quem embarcou em Campo Grande e Nova lguaçu também não precisou passar pela Avenida Brasil e pela Dutra, respectivamente (ver figura 31).

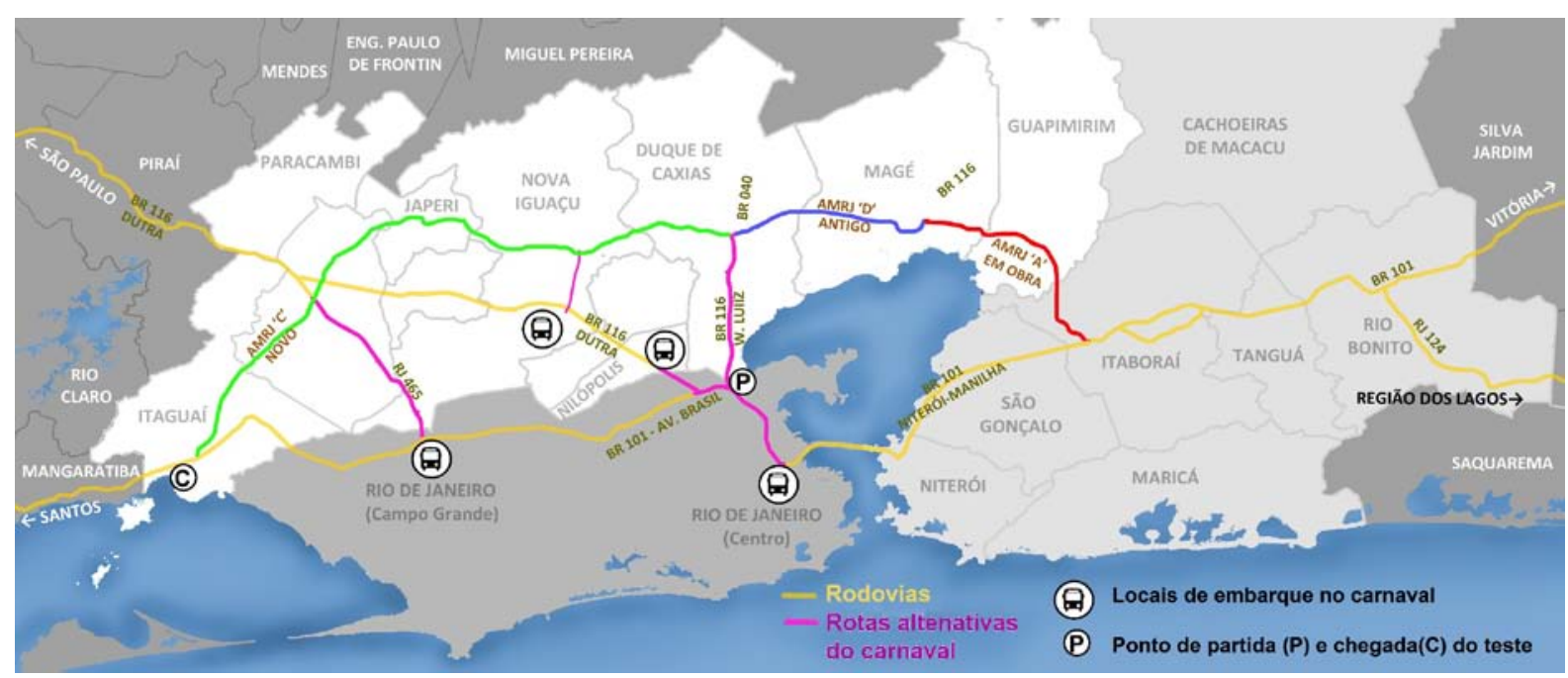

Figura 31 - Arco após inaugurado o trecho "C". Fonte: Elaboração própria com dados do DER-RJ (2006), G1 RIO (03/02/2015) e Mendonça e Brito (2014).

Ainda assim, na sexta feira que antecedeu o carnaval, os jornais já noticiavam que, logo no início dessa manhã, a Ponte Rio-Niterói já apresentava intenso fluxo de veículos. Por volta das $8 \mathrm{~h} 30$ o tempo médio de travessia, sentido Niterói, era de 40 minutos (uma média de velocidade de $19 \mathrm{Km} / \mathrm{h}$ ). De acordo com a CCR Ponte, este é o maior movimento do ano. Por volta das 8h20, os motoristas já enfrentavam 13 quilômetros de lentidão na rodovia Niterói-Manilha, no sentido Região dos Lagos (G1 RIO, 13/02/2015). 
Desta forma, ainda que em casos de trânsito extremo, como no carnaval, a rota via Arco seja mais rápida, no dia a dia essa melhora não se repete. Após a inauguração do Arco uma equipe de jornalismo do sistema globo de comunicação fez um teste: dois veículos saíram ao mesmo tempo do acesso da BR-040 na Avenida Brasil e foram até o Porto de Itaguaí. Uma equipe de reportagem fez o trajeto via o AMRJ e outra seguiu pela Avenida Brasil para analisar o trajeto antigo para o mesmo destino e fazer uma comparação. A equipe que foi pelo Arco demorou cerca de 1h23min para percorrer $93 \mathrm{~km}$ de estrada. Já a equipe que foi pelo caminho antigo chegou mais rápido ao destino final, levando 1 h02min para fazer o trajeto de $63 \mathrm{~km}$. (MENDONÇA; BRITO, 2014)

Também contrariando a justificativa tão propagandeada, após a inauguração do Arco não foi percebida nenhuma melhora no fluxo diário da ponte Rio-Niterói. Fica claro que os anúncios de melhora do fluxo de veículos da Ponte foram feitos essencialmente com intuito de convencer a população usando casos de forte apelo popular.

Pelo exposto, reiteramos que, atualmente, o Arco satisfaz sobretudo às necessidades dos grandes proprietários de indústrias e representantes do setor logístico de escala local e nacional. Este posicionamento foi explicitado em reportagem da Agência Brasil ${ }^{63}$ na qual o presidente da Federação das Indústrias do Estado do Rio de Janeiro (FIRJAN), Eduardo Eugênio Gouvêa Vieira, afirmou que há mais de 15 anos a construção do Arco é uma demanda das indústrias do estado para o escoamento das mercadorias. De acordo com declarações do próprio Sérgio Cabral (na época governador do estado do Rio de Janeiro) durante o seminário "Arco Metropolitano: um novo marco no desenvolvimento metropolitano"64, "0 Arco Metropolitano é a grande oportunidade de negócios nos próximos 20 anos”, uma vez que:

0 Estado está construindo $70 \mathrm{~km}$ de estrada onde não havia nada, transformando a região com uma ocupação que queremos inteligente por parte de empresas comerciais, indústrias, de serviços e de logística, casando o COMPERJ com o Porto de ltaguaí e todas as rodovias federais que passam pelo Rio de Janeiro (CABRAL in CARVALHO, 2011 ${ }^{65}$ ).

Contudo, em uma perspectiva de longo prazo há a possibilidade de novas centralidades se desenvolverem nos pontos de interseção do Arco com as vias existentes,

\footnotetext{
${ }^{63}$ Publicada no dia 18/04/2011, disponível em: http://agenciabrasil.ebc.com.br/noticia/2011-04-18/governolanca-plano-estrategico-para-evitar-degradacao-na-regiao-do-arco-metropolitano. Último acesso em 03 de março de 2012.

${ }^{64}$ Realizado no dia 18/04/2011, na sede da Firjan, no Centro do Rio de Janeiro.

${ }^{65}$ Notícia escrita por Marcela Carvalho, publicada no dia 18/04/2011 no site do governo do estado, disponível em: http://www.rj.gov.br/web/sedrap/exibeconteudo?article-id=427346. Último acesso em março de 2012.
} 
densificando o entorno desses nós, conforme mostra a prospecção de cenários realizada por Rego (2011). Assim, analisando um possível cenário de longo prazo, o Arco pode ser um indutor de uma redistribuição de oferta de empregos e serviços na RMRJ. Hoje em dia, boa parte da população da RMRJ busca empregos no centro, na zona sul e na zona oeste da capital fluminense. A criação de novas centralidades ou o crescimento de centralidades já existentes nos municípios cortados pelo Arco, pode redistribuir o fluxo de pessoas, aliviando problemas de deslocamento casa-trabalho. Assim, podemos dizer que o Arco facilita o inicio de um possível processo de descentralização da metrópole. Caso esse processo de fato ocorra nas próximas décadas, o Arco poderá ter um papel fundamental no transporte metropolitano.

Contudo, pelo exposto, percebemos que no cenário atual, o Arco pouco ou nada contribuirá para a melhoria de vida da população fluminense no que diz respeito à locomoção. A resolução dos problemas de mobilidade urbana da Região Metropolitana do Rio de Janeiro passa, primordialmente, pela expansão da linha de metrô; pelo aumento da frequência das linhas de trem, de ônibus e das barcas; pela inclusão de novos trajetos das barcas, com a criação de estações em São Gonçalo, por exemplo e, ainda, pela melhoria das embarcações, dos vagões e dos ônibus.

Assim, o AMRJ é um exemplo de empreendimento público com discurso de viés neodesenvolvimentista que prioriza obras que beneficiam o setor econômico, e, consequentemente, grandes empresas, em detrimento a obras que influenciem diretamente na melhoria da qualidade de vida da maior parte da população. 0 investimento de $R$ \$ 1,9 bilhão ${ }^{66}$ no AMRJ destina-se à construção de uma nova via que beneficia empresas do setor logístico. Contudo, para ter respaldo na sociedade, a justificativa de necessidade de implantação dessa via utiliza um discurso ideológico, baseado em uma suposta melhoria de mobilidade urbana na metrópole.

Autores como Cardoso e Araujo (2012) já haviam levantado a hipótese de que as decisões do Estado com relação ao Arco poderiam ter sido direcionadas para beneficiar os segmentos industrial e logístico. Assim, o Estado além de ter o papel de gestor, passa a atuar no "empresariamento" desta nova região industrial. Ele faz não só a infraestrutura da área como também investe nas empresas públicas e em financiamentos para empresas privadas. Além disso, atua no marketing do local propagando a ideia de transformação da área, para atrair novas empresas privadas.

\footnotetext{
${ }^{66}$ Segundo Blog do Planalto (2014).
} 
Este fenômeno já foi estudado por diversos autores, inclusive por Harvey (1996), que o denominava como o "novo empresariamento urbano". Segundo o autor, no empresariamento, o Estado insere, nas reivindicações locais, medidas públicas para tentar atrair novos investimentos diretos (com parcerias público-privadas, por exemplo) ou novas fontes geradoras de emprego (como é o caso do Arco).

Esse conceito também pode ser caracterizado pela governança com objetivos político-econômicos imediatos e que buscam mais o investimento e o desenvolvimento econômico através de empreendimentos pontuais e especulativos do que a melhora das condições de vida da população. Desta forma, o autor coloca que medidas provenientes do empresariamento urbano estão sujeitas a todas as dificuldades e perigos inerentes aos empreendimentos especulativos.

Segundo Harvey, "o empresariamento tem como foco de atenção muito mais a economia política do local, do que a do território”, entendendo a política do território como os projetos "concebidos primordialmente para promover melhorias nas condições de vida ou de trabalho em uma determinada jurisdição" (HARVEY, 1996, p.53). 0 autor também alerta que muitas vezes esses empreendimentos tornam-se o foco da atenção pública e privada, em detrimento aos problemas que de fato são os mais importantes para a população.

Tais empreendimentos podem, é claro, ser vistos como formas de gerar benefícios para populações de uma circunscrição específica e, de fato, essa é uma das principais reivindicações que surge na discussão pública que acontece para dar apoio a tais empreendimentos. Na maioria das vezes, porém, a forma assumida é tal que torna todos os benefícios indiretos e potencialmente de alcance mais amplo ou mais restrito do que a jurisdição em que são colocados. Projetos pontuais desse tipo também costumam tornar-se o foco da atenção pública e política a ponto de desviar a atenção e mesmo recursos de outros problemas mais importantes e que envolvem a região ou o território como um todo (HARVEY, 1996, p.53).

\subsubsection{Vazios urbanos da RMRJ}

Ao analisar os aspectos logísticos do Arco Metropolitano, o PDAM (2001) destaca que o transporte de carga passará a utilizar o Arco atravessando "áreas de ocupação rarefeita distantes de zonas densamente ocupadas, o que resulta em um efeito positivo de 
alta relevância para a região" (PDAM, 2011, p.456). Dentre estes efeitos, tal documento afirma que o Arco contribuirá para induzir a implantação de outros trechos rodoviários no seu entorno mediante a construção e/ou recuperação de acessos às novas áreas urbanas e industriais. Segundo o Plano, o "Arco Metropolitano induzirá fluxos migratórios para as áreas diretamente beneficiadas, reforçando o processo de aglomeração a se iniciar com a própria obra rodoviária e com os empregos por ela gerados” (PDAM, 2011, p.1).

Já o RIMA (2007) pontua, na sua lista de principais justificativas do Arco, que ele "introduz novas possibilidades de expansão urbana para os municípios localizados próximos à rodovia” (RIMA, 2007, pág.7).

A apresentação feita pela SEOBRAS (2007) enfatiza esse ponto listado no RIMA ilustrando-o com um mapa de "vazios urbanos da Região Metropolitana” (figura 32). Assim, fica claro que o Arco é também pensado como um novo vetor de expansão urbana nos municípios por ele cortados.

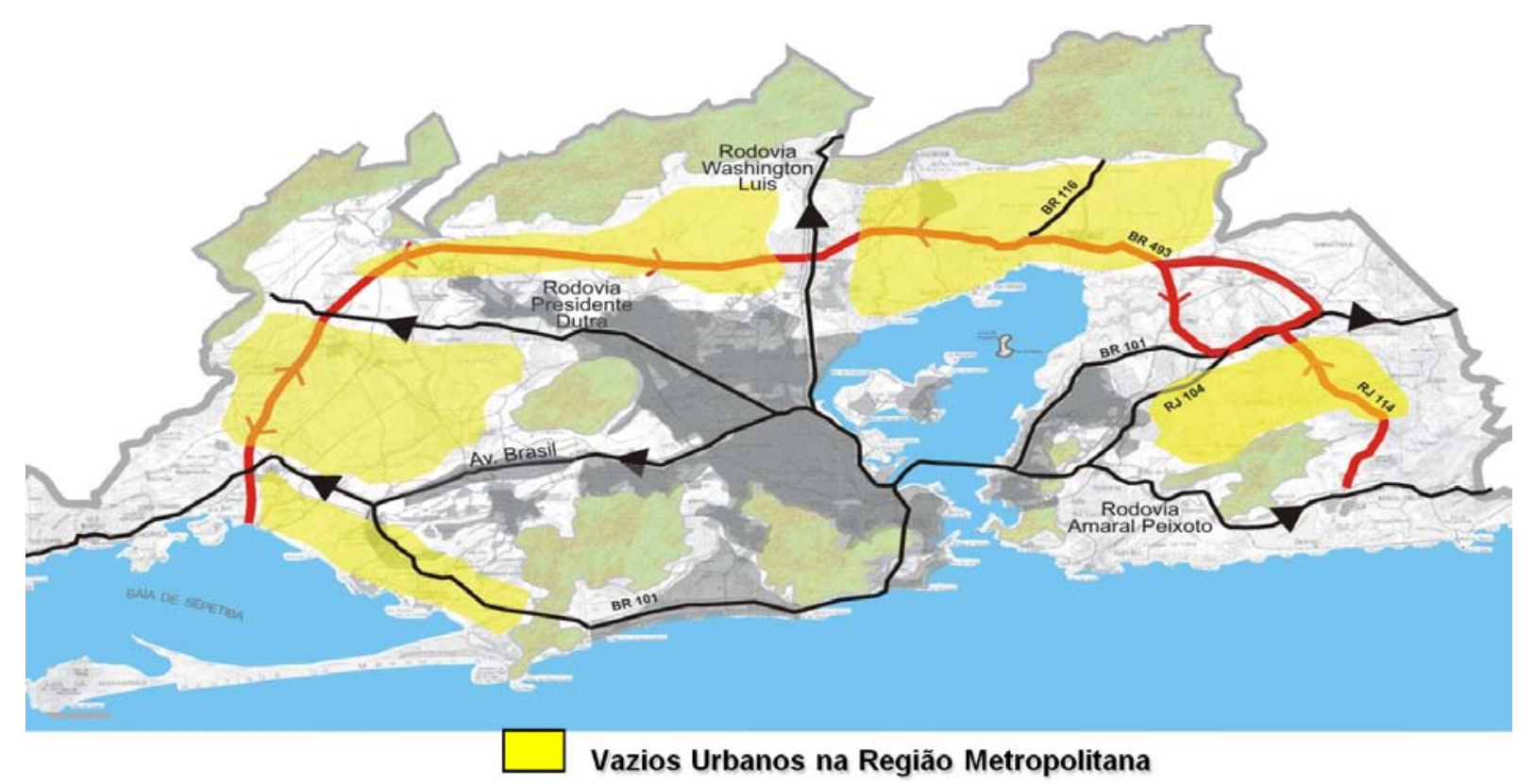

Figura 32 - 0 Arco e os vazios urbanos da Região Metropolitana. Fonte: SEOBRAS, 2007, Slide 22.

No discurso de inauguração do AMRJ, a presidente Dilma Rousseff afirmou que o Rio de Janeiro é um dos estados com ocupação territorial mais consolidada. Assim, na visão da governante, diferentemente do que acontece em alguns outros locais do país, na RMRJ é difícil se abrirem novas fronteiras territoriais. Nesse contexto, Dilma caracteriza o Arco como uma rodovia que liga grandes obras que estão sendo realizadas neste estado, mas ressalta que "ao fazer isso, abre o acesso a um território que estava desocupado e que estava na 
Baixada. Sendo assim, abre oportunidades sociais e econômicas” (SITE DO PLANALTO). Por conta dessa particularidade, Dilma chama o Arco de "caminho do futuro".

Tanto o PDAM (2011) quanto o RIMA (2007) preveem que as novas oportunidades de emprego gerarão uma redistribuição da população na RMRJ. Cardoso e Araujo (2012) também apontam para essas mudanças demográficas de atração e expulsão populacional. Ao analisar as possíveis transformações das centralidades hoje existentes, Rego (2011) acredita que o Arco por si só não modificará significativamente toda a rede urbana. Porém, a autora ressalva que, se pensarmos no conjunto de empreendimentos vinculados ao Arco, é inexorável o poder transformador do Arco na mancha urbana da RMRJ.

Como vimos, essa forte tendência de atração populacional já está se confirmando. Diversas são as empresas que estão comprando terrenos no entorno imediato do Arco para futura construção de empreendimentos residenciais e hoteleiros. Cardoso e Araujo (2012) exemplificam essa movimentação imobiliária:

A expansão residencial no território do leste fluminense tem sido apontada como uma saída estratégica para o saturado mercado imobiliário da cidade do Rio de Janeiro. Desta forma, na Baixada Fluminense estão sendo previstos grandes empreendimentos habitacionais dos mais variados padrões, para atender aos diversos perfis socioeconômicos decorrentes dos diferentes tipos de empregos que serão ali gerados. A empresa Brascan Residential Properties, por exemplo, tem investido profundamente nas áreas de influência do Arco Metropolitano, e já comprou terrenos no município de Maricá com dimensões de 5,5 milhões de metros quadrados e 8 milhões de $\mathrm{m}^{2}$, os quais abrigarão setores hoteleiros e residenciais (CONSTRUÇÃO e MERCADO, 2008). Terrenos situados nos municipios de Nova lguaçu, Seropédica e ltaguai também estão na mira do setor empresarial: a incorporadora InPar, por exemplo, investiga possibilidades de investimentos nestas áreas e afirma que já havia um processo de revalorização da Baixada Fluminense que o Arco Metropolitano tende a impulsionar ainda mais (ibidem). (CARDOSO E ARAÚJO, 2012. p. 111).

Para os autores, há uma tendência de expansão do mercado imobiliário no Rio de Janeiro em direção à Baixada Fluminense acompanhada de uma crescente valorização nos últimos anos. Parte dessa expansão imobiliária se deu a partir da inserção de crédito no setor habitacional, sobretudo com o Programa Minha Casa Minha Vida (PMCMV). Tal programa viabilizou financiamentos a longo prazo para famílias com renda de até dez salários mínimos. Comumente são habitações oferecidas nas franjas da mancha urbana, onde os terrenos são consideravelmente mais abundantes e baratos.

0 crescimento imobiliário gerado pelo AMRJ vem sendo noticiado nos sites especializados. Em páginas da internet voltadas para compra e venda de imóveis é comum ver anúncios que destacam no título a proximidade com o Arco. Em novembro de 2014, o 
portal da editora de revistas do setor de construção civil, PINIWEB, publicou uma reportagem na qual se destacava o estimulo ao mercado imobiliário na Baixada em decorrência do Arco Metropolitano e COMPERJ.

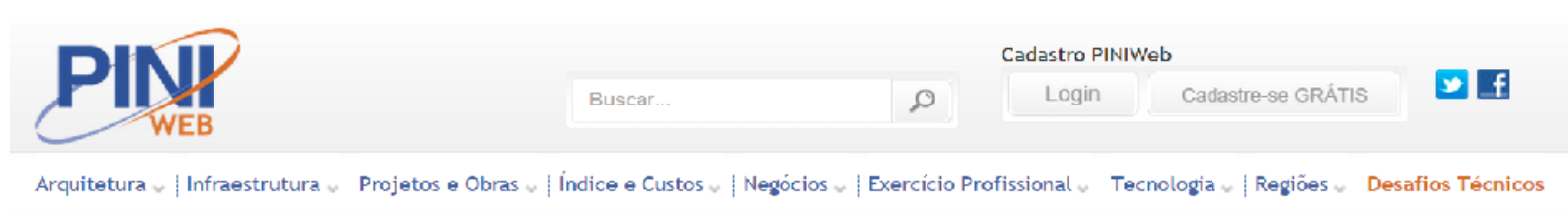

\section{Rio de Janeiro}

Notícias

\section{Arco Metropolitano e Comperj estimulam mercado imobiliário na Baixada}

Diversos condomínios horizontais são lançados na região e também na rodovia que liga Itaboraí a Maricá

Maria Vasquez

$21 /$ Novembro/2014

Tweet $\{0$ If Recomendar $3 8 + 1 \longdiv { 0 }$

Arco Metropolitano e Comperj estimulam mercado imobiliário na Baixada

Ver Maior

Figura 33 - ”Boom” imobiliário no entorno do Arco. Fonte: VASQUEZ (2014).

Segundo a reportagem de Vasquez (2014) no portal PINIWEB, a grande tendência para a Baixada é o surgimento de novos condomínios horizontais, com infraestrutura de segurança e de lazer, além de lojas de conveniências e salas de serviços. A jornalista informa que vários empreendimentos desse gênero foram lançados nas cidades da Baixada Fluminense, com terrenos a partir de sessenta mil reais. Para ela, "cada vez mais empresas e indústrias se instalando na região, essas cidade deixam de ser apenas dormitórios para serem também geradoras de arrecadação.” (VASQUEZ, 2014). A jornalista cita dois exemplos de empreendimentos desse tipo:

Um exemplo desses empreendimentos é o Granland lguaçu, da Facility Realty, o primeiro condomínio-clube da região. 0 projeto oferece 209 lotes, de 200 $\mathrm{m}^{2}$, podendo ser adquiridos dois, três ou mais lotes formando lotes de $400 \mathrm{~m}^{2}$ ou $600 \mathrm{~m}^{2}$, para a construção casas duplex de três e quatro quartos. 0 empreendimento oferece uma ampla estrutura de lazer e ainda a comodidade de estar perto de um dos principais e mais novo shopping da região.

Outra área valorizada é a cidade de Maricá. A RJ 114, conhecida como a Rodovia do Petróleo por ligar Itaboraí a Maricá, já conta com vários empreendimentos do tipo. A Alphaville Urbanismo investiu em Maricá com o bairro planejado Terras Alphaville Maricá que foi entregue no ano passado e já registra valorização de 70\%. (VASQUEZ,2014), 
Um outro exemplo é o Fusion Work and Live, localizado em um terreno de 15 mil metros quadrados de Itaguaí. Este condomínio da João Fortes Engenharia possui salas comerciais de $23 \mathrm{~m}^{2}$ a $389 \mathrm{~m}^{2}$, apartamentos de $61,10 \mathrm{~m}^{2}$ a $143,06 \mathrm{~m}^{2}$ e apartamentos com serviços de $37 \mathrm{~m}^{2}$ a $43 \mathrm{~m}^{2}{ }^{67}$

Devido a esse "boom" imobiliário no entorno do Arco, Moraes (2013) pergunta: “Afinal, a quem pertence o Arco Metropolitano do Rio de Janeiro?". Cardoso e Araujo (2012) comentam que o crescimento dos investimentos imobiliários ali realizados englobam também grandes incorporadoras, como a RJZ Cyrela, que tem apostado em empreendimentos de alto padrão na Baixada Fluminense. Para eles, esse interesse na Baixada é também impulsionado pelo AMRJ. O presidente da Brascan, Marcos Levy, confirma que: "0 Arco Rodoviário, com o Polo Petroquímico de ltaboraí, está trazendo investimentos da ordem dos bilhões de dólares. (...) Esse será o grande boom imobiliário do Rio” (CONTE, 2008).

Com tantos atrativos sendo criados, é consenso que ocorrerá um crescimento demográfico significativo na região de influência do Arco. Novamente frisamos que não estamos aqui condenando como maléfico todo e qualquer crescimento demográfico. A questão aqui é como se dará tal crescimento. A descentralização da oferta de emprego na metrópole fluminense nos parece bastante positiva, pois, como vimos, a população da região metropolitana fluminense padece de muitos problemas de mobilidade dado que uma grande quantidade de pessoas necessita se deslocar todos os dias de suas casas em cidades da periferia da RMRJ, rumo à seus empregos na capital.

0 fato de o Arco ter um plano diretor que aborda esse assunto, nos parece bastante positivo. Afinal, é necessário pensar a estruturação do território a longo prazo. Contudo, cabe lembrar que, para que essa descentralização econômica seja bem sucedida, não basta construir uma rodovia e incentivar os setores comerciais. É necessário planejar o rebatimento do seu processo em todas as demais áreas.

Na visão de Moraes (2013), a escala estadual e nacional de benefícios do Arco faz com que a micro escala dos territórios cortados pela rodovia não seja enxergada com o devido cuidado. A autora explicita a importância de analisar o Arco em todas as escalas, destacando a relevância de singularizar as situações, de não desprezar as heterogeneidades da região atingida e de não ignorar a população local. Para ela, esses pontos não estão

\footnotetext{
67 Fonte de informações: http://www.joaofortes.com.br/institucional/ficha/FusionComplexoMetropolitano Deltaguai /conteudo.aspx\#mn_empreendimento
} 
sendo levados em consideração e, com isso, teremos graves problemas socioambientais, apesar dos benefícios econômicos intrínsecos a uma obra deste porte.

Lembramos que a expansão econômica e demográfica do Arco pode se dar, territorialmente, de modo a expandir a mancha urbana ou de modo densificar a mancha já existente. Apesar de estudar prováveis cenários de espraiamento urbano, Rego (2011) também desenha um possível cenário otimista, no qual não ocorrerá dispersão urbana, nem crescimento sobre áreas atualmente "livres". Neste cenário, a autora afirma que novas centralidades poderão surgir em áreas já urbanizadas e outras centralidades já existentes poderão se fortalecer, em um movimento de densificação do meio urbano e não de crescimento espraiado da mancha urbana.

Ferreira e Ferrara (2012) lembram que, nas últimas décadas, ${ }^{68}$ essa defesa de uma "compactação" das cidades vem ganhando força entre aqueles que buscam a chamada "sustentabilidade urbana". A principal vantagem da "cidade compacta" seria o melhor aproveitamento das redes de infraestrutura urbana (de abastecimento de água, saneamento, recolhimento de resíduos sólidos, iluminação publica, sistema de transporte público, etc.). Assim, também se reduziria o tempo de deslocamento e, consequentemente, se reduziria o consumo de combustíveis gastos com a mobilidade urbana.

Contudo, o Plano prevê que esse fenômeno da expansão econômica e demográfica ocorrerá de forma espacialmente desigual: em alguns locais haverá o aumento da densidade populacional e em outros a expansão da mancha urbana com a ocupação de novas áreas.

Os grupos de trabalho das oficinas realizadas pelo grupo de pesquisa SEL-RJ demonstraram preocupação com a urbanização dos espaços que ainda permanecem livres de edificações. Sobretudo aqueles que possuem ocupação rarefeita ou estão em encostas ambientalmente sensíveis junto à unidades de conservação. Segundo lsidoro, Alcantara e Tângari (2011), nessas oficinas foram citados problemas de delimitação das áreas destinadas ao uso industrial e a inexistência de critérios ou limites de ocupação dos espaços livres existentes.

Ao descrever a área de estudo $2^{69}$, o PDAM menciona que já ocorrem nessa área movimentos de transformação demográfica e alteração do uso do solo. Sendo assim,

68 Tendo como marco referencial o ano de 1992 com a realização da Conferência da ONU sobre Desenvolvimento e Meio Ambiente, em que se estabeleceu os princípios da Agenda 21.

${ }^{69}$ Constituída pelos municípios de Japeri, Paracambi, Queimados, Nova lguaçu, Mesquita, Nilópolis, São João do Meriti, Belford Roxo, Duque de Caxias e Magé e também pela Área de Planejamento 3 do município do Rio de janeiro. 
constata que muitas localidades rurais já estão se consolidando como urbanas ou industriais.

Cardoso e Araújo (2012) também afirmam que a influência do AMRJ no processo de expansão da mancha urbana já vem ocorrendo desde o anúncio e início das obras, em 2007. Segundo estes autores, as regiões vizinhas ao Arco vêm sendo cada vez mais alvo de ocupação territorial, tanto para fins industriais quanto residenciais. As indústrias são atraídas pela infraestrutura de portos, aeroportos e pelo COMPERJ. Já a população é atraída pelas ofertas de emprego da etapa de obras e pela propagação do discurso ideológico (já citado no item 3.2) de futura criação de novos postos de trabalho.

$\mathrm{Na}$ estrada de Adrianópolis, localizada no município de Nova lguaçu, é possível observar a expansão da malha urbana nas áreas próximas ao ARMJ, pois ao longo dela se proliferaram indústrias. Além disso, foi visível a expansão espacial do aterro municipal que também fica próximo a esse entroncamento (CARDOSO E ARAÚJO, 2012).

Pela análise de imagens de satélite entre 2006 e 2015, podemos observar o rápido crescimento de Itaguaí. Na figura 34 marcamos em amarelo as áreas que em 2006 eram cobertura vegetal e em 2015 já está ocupada. Assim, notamos que a urbanização se deu com a expansão da malha urbana nas proximidades do Arco e da Rodovia Rio-Santos (RJ099).

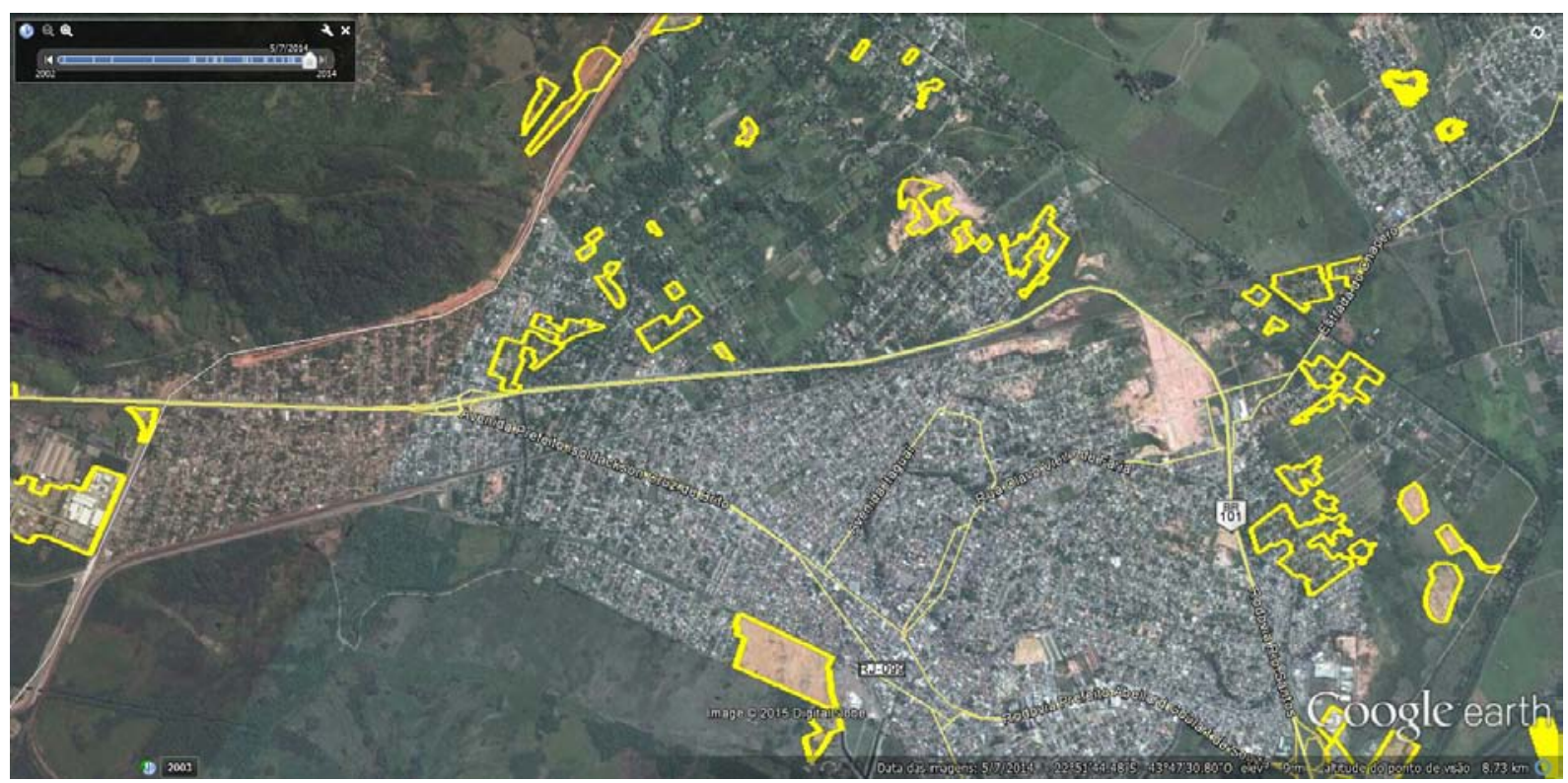

Figura 34 - Áreas desmatadas para extração mineral em Seropédica (surgimento entre 2006 e 2015). Fonte: Elaboração própria com base em imagens do Google Earth, 2015.

Apesar dessa justificativa de possibilidade de expansão territorial se apresentar como um aspecto positivo do ARMJ, tanto o RIMA (2007) como o PDAM (2011) consideram que 
tal expansão pode se desdobrar em aspectos negativos, acarretando uma série de problemas, como veremos a seguir.

Ao longo do Plano também são citadas algumas preocupações com a possível ocorrência de impactos socioambientais negativos por conta de desdobramentos da construção do Arco Metropolitano. Dentre os processos negativos decorrentes do crescimento econômico e do crescimento populacional, o plano destaca o aumento da demanda por infraestrutura e serviços públicos e a geração de externalidades negativas ambientais e sociais. Esses fatores, aliados à provável ocorrência de áreas de baixa densidade econômica nas zonas rurais e periurbanas, fazem com que o Plano ainda aponte a tendência à ocupação de terras agrícolas por outros usos do solo, frisando sobretudo o risco de favelização.

Cardoso e Araujo (2012) destacam que o RIMA do Arco cita de forma superficial os impactos dessas dinâmicas decorrentes da implantação da rodovia e de seus empreendimentos estruturantes.

Lembrando da crítica de Villaça (1999) ao Plano Policromático de Doxiadis, que continha quinhentas páginas de diagnóstico e apenas nove sobre implementações, analisamos, também dessa forma quantitativa, os aspectos sociais do PDAM (2011).

Podemos facilmente constatar que, apesar do longo diagnóstico, a concepção de diretrizes para promover a qualidade de vida da população atingida não é o foco desse instrumento de planejamento. No total, o relatório final do plano possui mais de setecentas e quarenta páginas. No tópico de debate sobre os futuros impactos do Arco, há um item intitulado "5.3 Desenvolvimento Econômico e Social” que ocupa setenta e seis páginas. Ao vermos agrupadas em um só item a questão social e a questão econômica, pode-se imaginar que estes temas serão tratados de forma intimamente relacionada, sendo as questões econômicas pensadas com o propósito direto de gerar um desenvolvimento social.

Contudo, as primeiras setenta e quatro páginas desse item dispõem somente sobre questões econômicas. Nestas páginas o Plano cita, cidade a cidade, todas as grandes indústrias existentes e as que se instalarão em breve. Além disso, traça diretrizes específicas para o crescimento das indústrias, determinando qual a vocação industrial de cada cidade e informando suas potencialidades e suas condicionantes.

Dentre as "Condicionantes à ocupação econômica" de todas as áreas de estudo do Plano aparece a frase: "Alerta-se que o ordenamento territorial deve se ater ao risco de surgirem diversas ocupações subnormais e favelização" (PDAM, 2011, p. 489, 507, 528). 
Percebemos assim, que a questão econômica apenas se aproxima da questão social quando observa que esta, supostamente, pode condicionar e atrapalhar o crescimento econômico.

Assim, depois dessas setenta e quatro páginas há o subitem “5.3.6. Condições de Vida”, no qual as questões sociais são de fato o foco do debate. Porém, este subitem possui menos de duas páginas, nas quais o Plano traça, de forma genérica e superficial, diretrizes gerais sobre a temática social. 0 documento apenas lista os possíveis rebatimentos da expansão urbana. Entre eles: as pressões sobre o sistema de saúde e de educação disponível; o aumento do déficit habitacional, sobretudo no tocante à população de baixa renda; e o agravamento dos problemas de abastecimento de água e de saneamento ambiental.

Além disso, em outros momentos, o plano também cita como conseqüência do crescimento da malha urbana e das atividades industriais a expulsão da população local e o aumento das pressões sobre o meio ambiente. Veremos a seguir essas questões mais detalhadamente. 
Capítulo 4 


\section{Capítulo 4:}

\section{Impactos sobre a urbanização e o meio ambiente}

\subsection{Infraestrutura urbana básica}

Em decorrência desse processo de expansão econômica e demográfica, o PDAM (2011) prevê pressões sobre os sistemas de abastecimento de água, de coleta de resíduos sólidos, de energia elétrica, de manejo de esgotos sanitários e de águas pluviais, além do aumento de demanda por equipamentos de lazer, serviços de saúde e de educação.

0 documento destaca os riscos que corre o município de Guapimirim, que dista apenas oito quilômetros do COMPERJ. A pequena distância poderá transformar Guapimirim em uma importante opção de moradia para os trabalhadores do Complexo Petroquímico. Contudo, o Plano alerta que a infraestrutura do local, principalmente de água e esgoto, "ainda não oferece condições de receber uma ampliação significativa no contingente populacional” (PDAM, 2011, p.556).

Segundo Carneiro (2009), em vários municípios da Baixada Fluminense observa-se que historicamente a expansão do perímetro urbano se deu de forma descontrolada, uma vez que não foi acompanhada da infraestrutura e dos serviços básicos necessários. Para o autor, esta forma desorganizada de expansão comprova a falta de critérios técnicos e de planejamento na delimitação do perímetro urbano legal. Ele ainda expõe que muitas vezes, no processo de planejamento urbano, os municípios declaram como área urbana trechos de uso rural visando somente ao aumento da arrecadação tributária. Para Carneiro (2009), isto é feito sem que se pense nas implicações físicas que tal ação tem sobre as cidades, como a expulsão de atividades agrícolas produtivas, o aumento da especulação imobiliária, a descontinuidade do tecido urbano e a dificuldade para futura implantação de infraestrutura urbana.

0 ex-secretário de Obras do estado e atual governador, Luiz Fernando Pezão confirma a existência de uma histórica dívida pública com relação à infraestrutura urbana (JORNAL DO COMÉRC10, 2011). Contudo, enquanto a expansão urbana já se apresenta como uma realidade, implementada desde o anúncio da licitação do Arco, as melhorias de infraestrutura ainda são identificadas apenas nos discursos. 
O PDAM (2011) faz uma série de recomendações para os municípios da área de influencia do Arco no que tange à infraestrutura. Uma delas é a elaboração de estudo de viabilidade locacional para implantação de aterros sanitários intermunicipais que, segundo o plano, podem ser construídos e/ou operacionalizados por parcerias público-privadas. De fato foi construída em Seropédica uma Central de Tratamento de Resíduos (CTR),operada pela empresa Ciclus $^{70}$, através de concessão da Comlurb. Essa $\mathrm{CTR}^{71}$ recebe resíduos dos municípios de Seropédica, Itaguaí e do Rio de Janeiro.

Ainda sobre a questão dos resíduos sólidos, o Plano recomenda a implementação de ações como, por exemplo, um sistema de coleta seletiva dos resíduos urbanos e de centrais de compostagem. Porém, tais ações ainda não são realizadas plenamente nem na capital do estado, que possui a maior arrecadação e a melhor capacidade administrativa da RMRJ.

Em determinado momento, o PDAM (2011) coloca o esgotamento sanitário como o principal problema enfrentado pela população dos municípios da RMRJ. É importante lembrar que a questão sanitária tem vinculação direta com os problemas ambientais, a contaminação hídrica e os problemas de saúde mais comuns. Assim, o Plano destaca a urgência de resolução dessa questão enumerando diversas alternativas individuais e coletivas, como a construção de novas Estações de Tratamento de Esgoto (ETEs), mas faz ressalva à necessidade de se produzir um diagnóstico detalhado da situação para que se possa decidir sobre a melhor opção de encaminhamento da questão.

No capítulo de diretrizes, o PDAM (2011) descreve os próximos passos a serem tomados para minorar os problemas de saneamento ambiental, sendo eles: i) ampliar as alternativas de captação, tratamento, adução, reserva e distribuição de água, mediante identificação de novas fontes e novos sistemas ii) ampliar os estudos para identificar e resolver o grande atraso do serviço de esgotamento sanitário; e iii) planejar e implementar o Plano Regional de Macrodrenagem.

Cardoso e Araujo (2012) pontuam que sempre há a promessa de implantação de infraestrutura urbana nos municípios da Baixada, ainda que esta seja feita de forma superficial e pouco específica. Os autores colocam também que o PDAM e o RIMA

\footnotetext{
${ }^{70}$ A Ciclus (Razão Social: SERB - Saneamento e Energia Renovável do Brasil S/A) é uma concessão da Comlurb - Companhia Municipal de Limpeza Urbana - formada como Sociedade de Propósito Específico (SPE) que une a credibilidade da Júlio Simões em logística à expertise da Haztec em gestão de resíduos.

${ }^{71}$ Essa CTR conta com: aterro sanitário bioenergético, estação de tratamento de chorume para transformação em água de reuso, unidades de beneficiamento de entulho da construção civil e de podas de árvores, viveiros de mudas de espécies nativas da Mata Atlântica, laboratórios e Centro de Educação Ambiental e estação de captação e tratamento de biogás para geração de energia limpa.
} 
propagam a promessa de que serão tomadas medidas de contenção de ocupação desordenada e que não haverá espaço para expansão urbana desordenada. Tanto Cardoso e Araujo (2012) como Carneiro (2009) apontam que esse é apenas mais um discurso retórico que não será concretizado.

Tal posicionamento tem base no fato de que, na atualidade, a realidade dos serviços de saneamento ambiental é precária em todos os seus componentes.Segundo Carneiro (2012), até nos municípios com bons índices, como por exemplo, mais de 90\% de domicílios ligados à rede geral de água, são comuns problemas relativos à irregularidade na frequência do abastecimento,baixa pressão na rede e má qualidade da água que chega às residências. Por conta desses problemas, muitas vezes os moradores recorrem a soluções paliativas, como poços artesanais,para cobrir as falhas no sistema formal de abastecimento de água. Segundo o autor, as atuais deficiências no abastecimento de água e no esgotamento sanitários geram problemas de saúde pública, atingindo, sobretudo, as crianças.

Atualmente, os vinte e um municípios da área de abrangência do AMRJ apresentam um conjunto de indicadores que denotam grande precariedade e pobreza. Muitos, por exemplo, não têm condições de atender à demanda atual de tratamento e disposição de resíduos sólidos e também apresentam indicadores sociais deficitários no tocante aos serviços de saúde e de educação (CARDOSO, ARAÚJO, 2012).

Ao analisarmos os dados do Censo Demográfico de 2010 (figura 35), podemos notar que os municípios cortados pelo AMRJ apresentam, quase sempre, os piores índices em comparação aos demais municípios do estado do Rio de Janeiro. Dentre os oito municípios cortados pelo AMRJ, Itaguaí e Nova lguaçu se destacam como os que obtêm índices mais similares à média da RMRJ e à média de todos os municípios do estado de forma geral. 


\begin{tabular}{|c|c|c|c|c|c|c|c|c|c|c|c|}
\hline \multirow[b]{2}{*}{ Descrição do dado / Município } & \multicolumn{8}{|c|}{ Municípios do Arco Metropolitano } & \multicolumn{3}{|c|}{$\begin{array}{l}\text { índices para } \\
\text { Parâmetros }\end{array}$} \\
\hline & 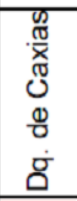 & 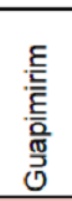 & 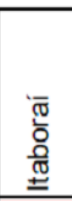 & $\begin{array}{l}\bar{\sigma} \\
\stackrel{\bar{J}}{\sigma} \\
\stackrel{\mathbb{\sigma}}{ \pm}\end{array}$ & 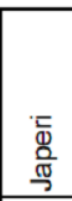 & 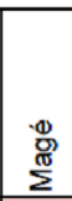 & 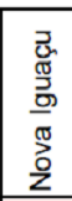 & 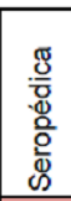 & 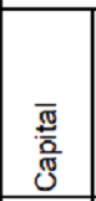 & $\sum_{\underline{x}}^{\vec{\alpha}}$ & 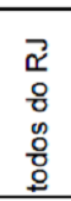 \\
\hline \% População residente em área rural & 0,3 & 3,4 & 1,2 & 4,5 & - & 5,3 & 1,1 & 17,8 & - & 3,0 & 15,7 \\
\hline $\begin{array}{l}\% \text { Pessoas com } 15 \text { anos ou mais que não } \\
\text { sabem ler e escrever }\end{array}$ & 5,0 & 7,5 & 6,6 & 5,4 & 7,1 & 5,9 & 4,6 & 5,9 & 2,9 & 5,0 & 7,8 \\
\hline \% Domicílios com saneamento adequado & 55,7 & 43,1 & 21,0 & 67,0 & 55,9 & 30,8 & 64,7 & 62,0 & 93,5 & 60,4 & 59,3 \\
\hline \% Domicílios com saneamento semiadequado & 42,8 & 53,4 & 74,7 & 31,6 & 41,7 & 66,2 & 33,6 & 35,6 & 6,5 & 37,6 & 35,4 \\
\hline \% Domicílios com saneamento inadequado & 1,5 & 3,2 & 3,9 & 0,6 & 2,5 & 2,5 & 1,4 & 0,9 & 0,0 & 1,5 & 0,8 \\
\hline $\begin{array}{l}\text { Rendimento médio mensal domiciliar per capita } \\
\text { nominal (em R\$) }\end{array}$ & 498 & 505 & 482 & 546 & 368 & 478 & 493 & 528 & 1.204 & 614 & 580 \\
\hline $\begin{array}{l}\% \text { pessoas com rendimento mensal domiciliar } \\
\text { per capita nominal de até } 1 / 2 \text { salário mínimo }\end{array}$ & 35,1 & 38 & 37,8 & 32,3 & 47 & 38,8 & 37,8 & 35,4 & 20,7 & 33,1 & 34,5 \\
\hline
\end{tabular}

Municípios com índices piores do que: Legenda de cores:

1 dos índices de parâmetro

2 dos índices de parâmetro

3 dos índices de parâmetro

Figura 35 - Precariedade atual dos municípios cortados pelo AMRJ. Fonte: Elaboração própria com dados do Censo Demográfico 2010 - IBGE. Índices sociais do estado do Rio, da RMRJ e dos municípios cortados pelo AMRJ - CENSO 2010.

Pelos dados do censo (Figura 35), também podemos notar que a questão do saneamento se revela problemática em cinco dos oito municípios cortados pelo Arco: Duque de Caxias, Guapimirim, Itaboraí, Japeri e Magé. Desses, o município de Itaboraí(local do COMPERJ), merece destaque, porque possui os piores índices, tendo apenas 21\% dos domicílios com saneamento adequado, 74,7\% com saneamento semiadequado e 3,9\% com saneamento completamente inadequado.

Um estudo da FIRJAN (2008) revela que após o asfaltamento da rodovia Rio-Santos (na década de 1970) os municípios cortados pela via passaram a apresentar índices piores do que os demais municípios da Região Metropolitana de São Paulo (RMSP) e da Região Metropolitana do Rio de Janeiro (RMRJ), conforme mostram os gráficos a seguir.

Quanto à questão dos domicílios atendidos por rede geral de esgoto, nota-se claramente na figura 36, que enquanto nos municípios fora da Rio-Santos havia uma crescente e significativa melhora, nos municípios da Rio-Santos a situação se agravou. 


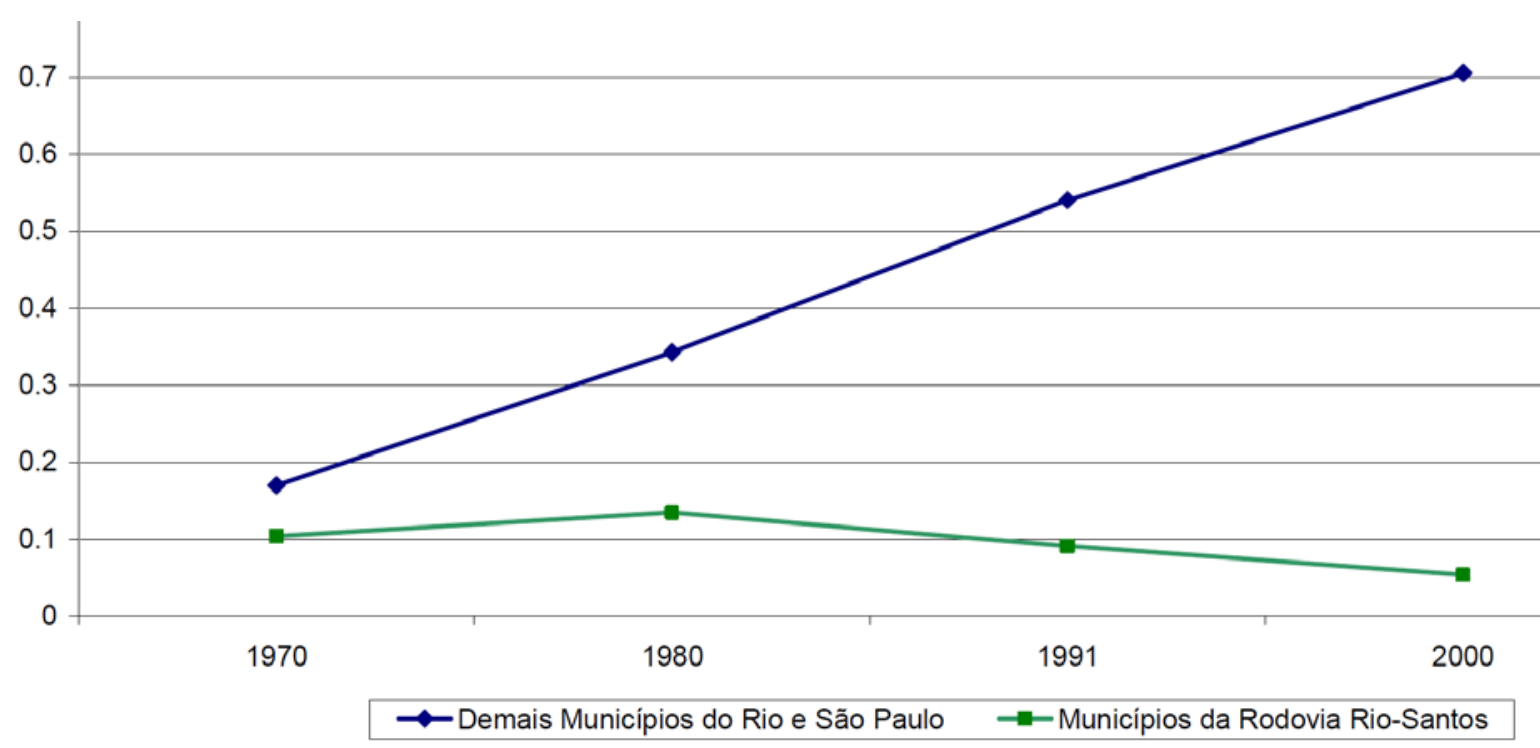

Figura 36 - Rodovia Rio-Santos - Evolução percentual de residentes com rede geral de esgoto.Fonte: FIRJAN (2008) a partir de tendências e microdados dos Censos demográficos de 1970, 1980,2000 (IBGE).

Quanto à iluminação, os gráficos mostram que a situação dos municípios da RioSantos não é consideravelmente diferente da situação dos demais. Porém, quanto aos indices de trabalho infantil, ocorreu também um grande prejuízo nas áreas da rodovia. Pelo gráfico da figura 37 nota-se que os municípios da Rio-Santos não acompanham a queda acentuada nesse indicador observada nos demais municípios a partir de1980. Nos municípios da Rio-Santos, a queda só ocorre a partir de 1991 e, mesmo assim, de forma bem tímida.

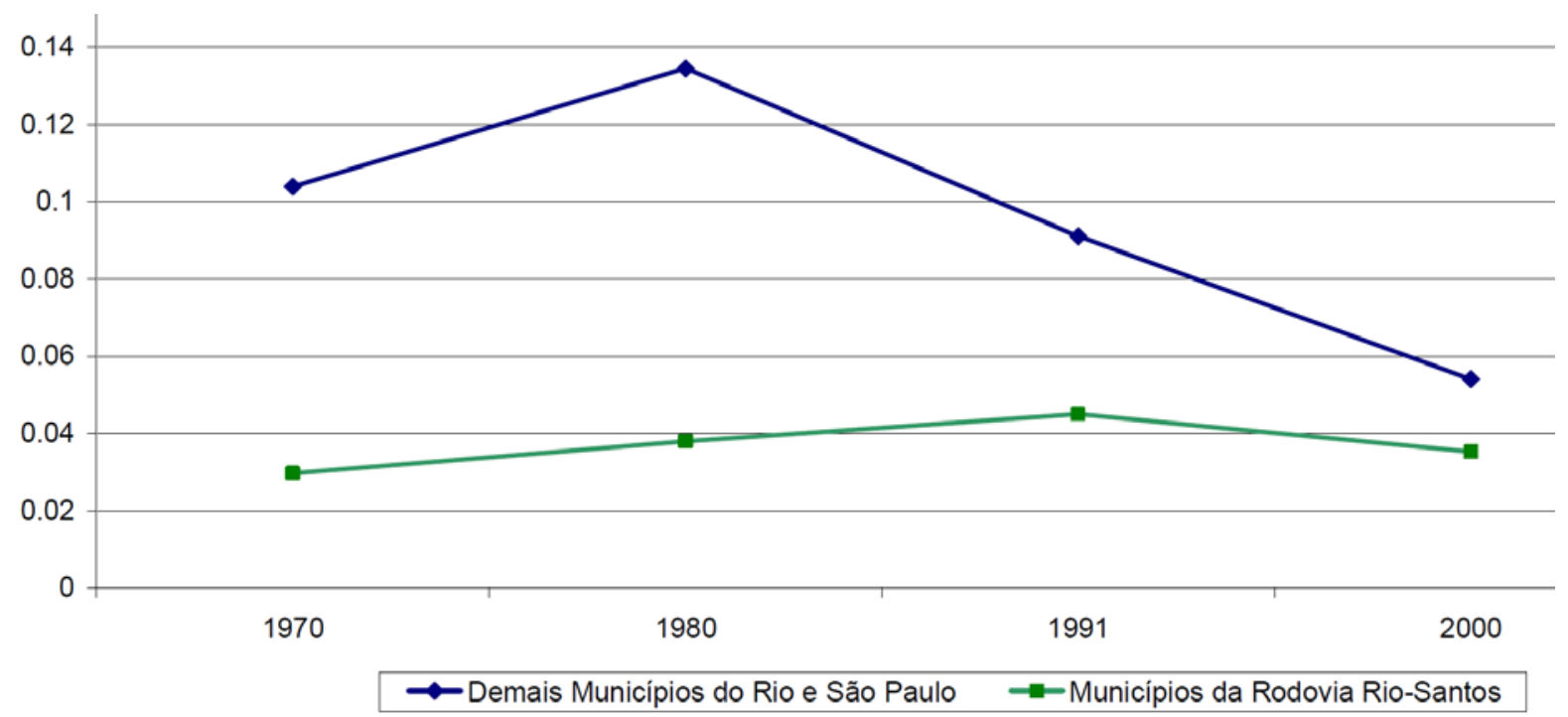

Figura 37 - Rodovia Rio-Santos - Evolução percentual de crianças que trabalham. Fonte: FIRJAN (2008) a partir de tendências e microdados dos censos demográficos de 1970, 1980,2000 (IBGE). 
Como apontado no estudo da FIRJAN (2008), há indícios de que as administrações dos municípios cortados pelo Arco terão que lidar com impactos semelhantes a estes citados. Agrava essa situação o fato de que estes municípios já apresentam atualmente, como vimos na figura 35, índices preocupantes, quando comparados aos demais municípios do estado do Rio de Janeiro.

Nesse contexto de precariedade de infraestrutura básica, Pinto (2010) afirma que "a implantação do Arco Metropolitano e do COMPERJ servirá como atração de numerosos contingentes populacionais, agravando as precárias condições de moradia e infraestrutura das populações locais" (PINTO, 2010).Ao citar empreendimentos como o COMPERJ, a CSA, a CSN, as obras no Porto de Itaguaí, as obras de Macrodrenagem e Urbanização e a construção do Arco Metropolitano, Carneiro (2012) expõe que dentre os empreendimentos projetados, o Arco provavelmente é o que causará transformações mais significativas na estrutura urbana da Baixada Fluminense, criando novos vetores de expansão e novas centralidades urbanas.

Carneiro (2012)analisa o impacto do Arco Metropolitano na intensidade das inundações nas áreas urbanas situadas na bacia do rio lguaçu, na Baixada Fluminense. De acordo com essa análise, a falta de conexões viárias dos últimos anos foi o principal fator limitador da expansão urbana. Assim, ele alerta para o fato de que o novo trecho do traçado do Arco rodoviário passará justamente pelas áreas ainda não urbanizadas das bacias contribuintes à Baía de Guanabara.

Para este autor, a urbanização desses espaços intensifica a degradação ambiental e a impermeabilização dos solos. Conseqüentemente, essa nova grande área impermeável da RMRJ aumenta a possibilidade e a intensidade das futuras inundações.Assim, a manutenção dessa região com área não urbanizada é fundamental para o controle de inundações urbanas.Em determinado trecho, o PDAM (2011) parece concordar com Carneiro (2012). 0 Plano cita que a maior parte da Bacia da Baía de Sepetiba encontra-se desprovida de esgotamento sanitário, logo, “a situação sanitária da região é muito grave, principalmente nas áreas de baixada, sujeitas a inundações periódicas” (PDAM, 2011, p.93).

Ao falar da manutenção de áreas vazias nas marginais de cursos d'água (com criação de APPs) e da implantação ou recuperação de pôlderes, Carneiro (2012) destaca que essas são medidas importantes, mas não são suficientes para o controle de cheias. Ele enfatiza que para um melhor controle das inundações, é necessário pensar nas taxas de impermeabilização do território da bacia como um todo. Para isso, é necessário o estudo da 
proporção entre áreas urbanas e áreas livres. 0 autor ainda ressalta que medidas de controle de urbanização e, consequentemente de controle de impermeabilização do solo, têm custos infinitamente menores que a implementação da drenagem urbana em áreas sujeitas a alagamentos.

Desta forma, Carneiro (2012) defende que o aumento demográfico deve ser planejado e coordenado para que seja feito de modo a adensar áreas já urbanizadas. Assim, para conter a expansão urbana, ele sugere algumas alternativas. Dentre elas estão: a) a criação de uma Área de Preservação Ambiental (APA) de domínio estadual, garantindo uma zona de baixo impacto hidrológico ao adotar restrições para o uso do solo; b) a criação de um consórcio público voltado ao planejamento integrado de políticas públicas de impacto no território e de interesse plurimunicipal;e c) a implantação de medidas compensatórias de drenagem sustentável visando ao amortecimento de vazões nas partes altas da bacia. Com isso, o autor recomenda fortemente "a retomada do planejamento de longo prazo, calcados em mecanismos de cooperação eficazes, evitando-se arranjos com viés voluntaristas e de caráter eleitoral" (CARNEIRO, 2009, p. 3).

Nos grupos de trabalho das oficinas realizadas pelo SEL-RJ, surgiram algumas propostas relacionadas aos problemas do sistema de redes de infraestrutura. Entre as frases dos participantes dessas oficinas, lsidoro, Alcantara e Tângari (2011) destacaram que há uma preocupação com o crescimento populacional e a expansão urbana. Assim, foi considerada a necessidade de um trabalho conjunto entre governo e população para não saturar o sistema de redes de infraestrutura, especialmente saneamento básico. Entretanto, os moradores também frisam que tal infraestrutura deve ser implantada antes do aumento da demanda. Eles apontam que o crescimento industrial pode agravar problemas de saúde da população, que já sofre com redes de hospitais públicos inadequadas para atender a demanda atual. A preservação de áreas vegetadas e a sua vinculação com o sistema de saneamento ambiental também foram mencionadas no debate.

A falta de saneamento e a poluição provocada pelas novas fábricas que se instalarão na área podem agravar problemas com a SAÚDE da população, que não conta com redes de hospitais públicos adequada." (frase-conceito de participante) (ISIDORO, ALCANTARA E TÂNGARI, 2011, p. 14).

"É de suma importância que se promova a EDUCAÇÃO de forma ampla, para que consigamos preservar a COBERTURA DO SOLO melhorando sistematicamente a INFRAESTRUTURA de uma determinada região." (fraseconceito de participante) (ISIDORO, ALCANTARA E TÂNGARI, 2011, p. 9). 
Segundo Carneiro (2012), ao se autointitular como uma proposta com base no desenvolvimento sustentável, o projeto do AMRJ precisa contabilizar seus impactos urbanos. Para o autor, o PDAM e, sobretudo, o RIMA, deveriam ter debatido com profundidade as questões vinculadas ao crescimento da mancha urbana e sua ligação com a macrodrenagem da RMRJ.

Contudo, ao citar como justificativa do AMRJ, a "Introdução de novos vetores de expansão urbana para os municípios localizados em sua área de influência”, o RIMA (2007) se mostra altamente incongruente. 0 autor ressalta que este ponto deveria ser visto como justificativa inversa, ou seja, como razão justificatória da não construção da rodovia, devido aos inúmeros malefícios por esta ocasionados.

Cabe destacar que este último aspecto não é, necessariamente, mais uma virtude do projeto, como são os demais itens anunciados pelo governo do estado. Ao contrário, ao expandir a ocupação para os espaços ainda não urbanizados terse-ão intensificadas a degradação ambiental e a impermeabilização dos solos, cujos resultados são prejuízos sociais e econômicos, conforme demonstrado na modelagem hidrodinâmica apresentada no item 3.1. (CARNEIRO, 2012, p. 144).

Pelo exposto, percebemos que, no caso do Arco, se aplica um dos pontos colocados por Marx e Engels (1989) nos qual eles explicam que a ideologia é uma distorção da realidade, como uma câmara escura, a ideologia cria uma imagem invertida da realidade.

\subsection{Habitação}

Em 2010 o déficit habitacional do estado do Rio de Janeiro era de mais de quinhentas mil habitações. Destas, mais de duzentas mil correspondiam ao déficit da cidade do Rio de Janeiro e mais de cento e sessenta mil aos demais municípios da região metropolitana fluminense. Diferentemente do que ocorre no estado de São Paulo, tanto na região metropolitana como no restante do estado do Rio de Janeiro, o ônus excessivo com aluguel é o maior fator do déficit. Contudo, como em São Paulo, este fator e a coabitação são, sem dúvida, os dois primeiros motivos de déficit (figura 38). 


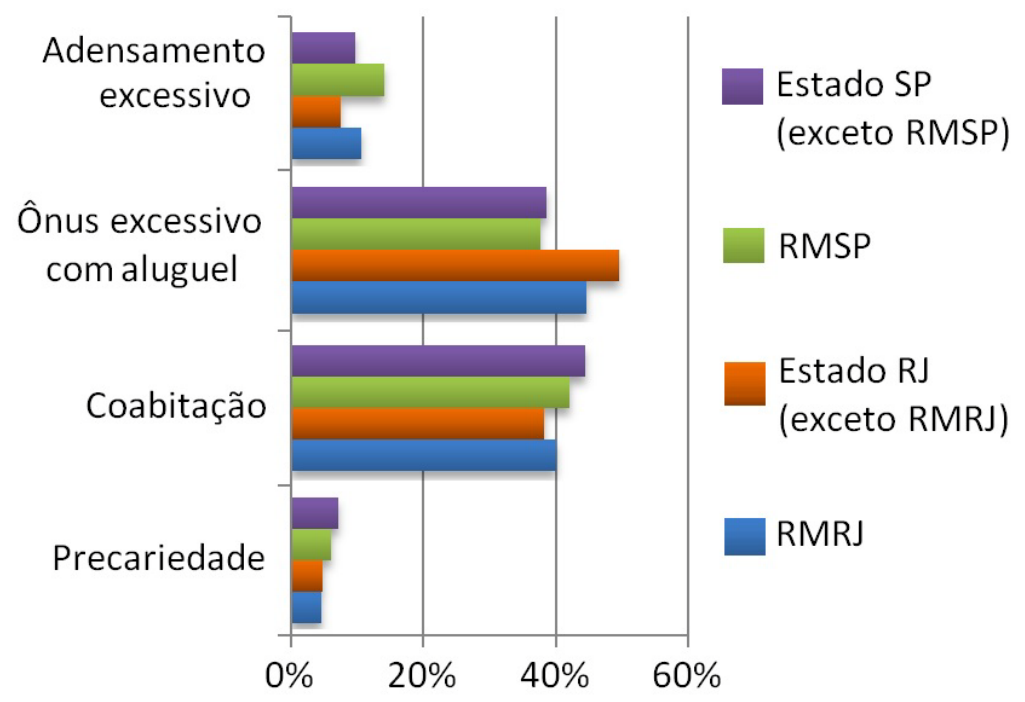

Figura 38 - Déficit habitacional relativo por componente. Fonte: Elaboração própria com base nos dados do censo demográfico, 2010 do IBGE, in (FUNDAÇÃO JOÃO PINHEIRO, 2013).

Ao falar do "histórico da rede de transporte" no item 4.1.4, o PDAM cita que as estradas são, por si só, um fator de crescimento demográfico. Assim, quando aliamos a atração gravitacional exercida pelas estradas com a atração dos empreendimentos Estruturantes, temos um quadro de potencial "boom demográfico". Como já vimos aqui, este quadro ocorre, sobretudo, devido à divulgação da ideia de criação de inúmeros novos empregos em diversos municípios da baixada fluminense. Portanto, exigem estratégias conjuntas que devem ser pactuadas de forma regional.

O Plano identifica, nos processos decorrentes da implantação do Arco Metropolitano, um fator de potencial mudança nos padrões de uso e ocupação da sua área de abrangência. Assim, possivelmente ocorrerá uma dinâmica típica da introdução de um novo eixo de transportes. O PDAM (2011) caracteriza essa dinâmica, inicialmente, pela instalação de atividades econômicas ou urbanas de grande porte, como indústrias ou shopping centers, por exemplo. Posteriormente essas atividades atraem atividades complementares de pequeno porte, dinamizando o processo de ocupação da área. Consequentemente, este desenvolvimento econômico mais completo gera crescimento populacional e demanda por habitação, que também geram demandas por educação, saúde, lazer, etc..

Por conta dessas alterações nos processos de uso e ocupação do solo, o Plano prevê a ocupação irregular de áreas protegidas ao longo do traçado do Arco, com a formação de aglomerados subnormais.Também antecipa que ocorrerá processos de especulação imobiliária e adensamento de áreas já urbanizadas. 
Assim, com base nos dados do déficit habitacional de 2007, o PDAM (2011) estuda as necessidades habitacionais e a projeção do número de domicílios da RMRJ e do Estado do Rio de Janeiro entre 2010 e 2030, apontando para dados alarmantes. "De fato, a solução do déficit habitacional existente e o atendimento à demanda futura vislumbram a necessidade da construção, no Estado, de quase 3 milhões de novas moradias” (PDAM, 2011, p.188). Dessas três milhões,um milhão e oitocentas habitações (63\%) seriam na RMRJ.

Motivados por duas questões, apresentaremos aqui nossos cálculos do crescimento do déficit. A primeira motivação se dá por possuirmos hoje acesso a dados mais atualizados que os do Plano, que usou informações do déficit de 2007 e de 2008 . A segunda é o fato do Plano não deixar claro qual é a faixa de renda dessa demanda habitacional futura. Para os nossos cálculos de projeção utilizaremos os percentuais de projeções do número de domicílios em 2020 e 2030 realizadas por David Vetter Consultoria Econômica Ltda., constantes do PDAM (2011). Porém, aplicaremos eles somente ao número do déficit de domicílio. Cabe lembrar que, no estado do Rio de Janeiro, sessenta e nove por cento do déficit habitacional corresponde às faixas de zero a três salários mínimos.

Ao analisarmos os dados de projeção do déficit habitacional, notamos que os municípios da RMRJ que terão as maiores taxas de crescimento (segundo David Vetter Consultoria Econômica Ltda.), são aqueles que possuem um déficit habitacional relativamente pequeno, em comparação com os demais municípios. Os municípios de Duque de Caxias e Nova lguaçu, por exemplo, possuem um déficit superior a vinte mil unidades habitacionais, mas crescerão a taxas menores do que a média do estado do Rio, ficando na média da RMRJ. Destacamos porém, o caso de ltaboraí e de Magé, que já possuem déficit habitacional superior a cinco mil habitações e possuem taxas de crescimento superiores à média estadual e à média da Região Metropolitana. 


\begin{tabular}{|c|c|c|c|c|c|c|c|}
\hline & 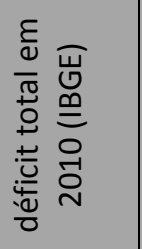 & 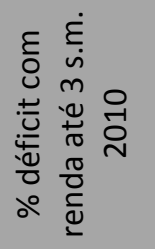 & 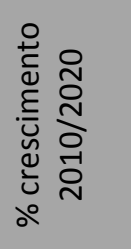 & 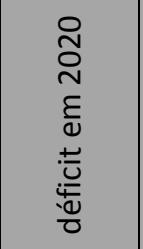 & 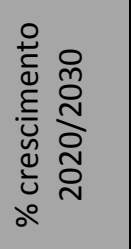 & 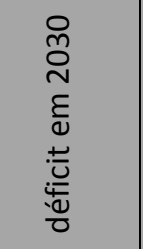 & 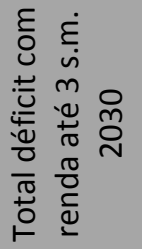 \\
\hline Capital & 220.774 & $68 \%$ & $12 \%$ & 247.266 & $18 \%$ & 291.774 & 198.679 \\
\hline \multicolumn{8}{|l|}{ Municípios cortados pelo Arco } \\
\hline Duque de Caxias & 26.555 & $71,4 \%$ & $12 \%$ & 29.742 & $18 \%$ & 35.095 & 25.042 \\
\hline Guapimirim & 1.397 & $74,1 \%$ & $24 \%$ & 1.733 & $33 \%$ & 2.305 & 1.709 \\
\hline Itaboraí & 5.993 & $70,7 \%$ & $17 \%$ & 7.012 & $24 \%$ & 8.694 & 6.145 \\
\hline Itaguaí & 3.512 & $67,2 \%$ & $21 \%$ & 4.250 & $29 \%$ & 5.482 & 3.683 \\
\hline Japeri & 2.366 & $71,2 \%$ & $12 \%$ & 2.650 & $18 \%$ & 3.127 & 2.228 \\
\hline Magé & 6.025 & $70,6 \%$ & $16 \%$ & 6.989 & $23 \%$ & 8.596 & 6.068 \\
\hline Nova Iguaçu & 22.072 & $65,7 \%$ & $11 \%$ & 24.500 & $16 \%$ & 28.420 & 18.680 \\
\hline Seropédica & 2.026 & $65,7 \%$ & $19 \%$ & 2.411 & $28 \%$ & 3.086 & 2.029 \\
\hline \multicolumn{8}{|l|}{ Demais municípios da RMRJ } \\
\hline Belford Roxo & 14.092 & $70,3 \%$ & $11 \%$ & 15.642 & $17 \%$ & 18.302 & 12.873 \\
\hline Cachoeiras de Macacu & 1.353 & $78,2 \%$ & $19 \%$ & 1.610 & $27 \%$ & 2.044 & 1.598 \\
\hline Maricá & 3.322 & $68,1 \%$ & $31 \%$ & 4.351 & $40 \%$ & 6.092 & 4.148 \\
\hline Mesquita & 5.794 & $69,0 \%$ & $9 \%$ & 6.315 & $14 \%$ & 7.199 & 4.970 \\
\hline Nilópolis & 6.214 & $66,6 \%$ & $9 \%$ & 6.774 & $14 \%$ & 7.722 & 5.145 \\
\hline Niterói & 12.690 & $61,6 \%$ & $12 \%$ & 14.212 & $18 \%$ & 16.771 & 10.338 \\
\hline Paracambi & 1.643 & $76,2 \%$ & $16 \%$ & 1.906 & $23 \%$ & 2.344 & 1.786 \\
\hline Queimados & 3.338 & $65,0 \%$ & $13 \%$ & 3.772 & $20 \%$ & 4.527 & 2.941 \\
\hline Rio Bonito & 1.713 & $70,4 \%$ & - & - & - & - & - \\
\hline São Gonçalo & 32.195 & $67,5 \%$ & $11 \%$ & 35.736 & $17 \%$ & 41.811 & 28.226 \\
\hline São João de Meriti & 16.462 & $70,4 \%$ & $8 \%$ & 17.779 & $13 \%$ & 20.090 & 14.136 \\
\hline Tanguá & 747 & $76,6 \%$ & $16 \%$ & 866 & $24 \%$ & 1.074 & 823 \\
\hline Total RMRJ & 390.282 & & $12 \%$ & 437.115 & $18 \%$ & 515.796 & \\
\hline Estado do Rio de Janeiro & 515.067 & & $15 \%$ & 592.327 & $22 \%$ & 722.639 & \\
\hline
\end{tabular}

Figura 39 - Evolução do déficit habitacional. Fonte: Elaboração própria com base em David Vetter Consultoria Econômica Ltda constantes (in PDAM, 2011, p.188) e Fundação João Pinheiro (2014).

Tendo em vista o crescimento do déficit habitacional nos municípios do entorno do Arco, o PDAM (2011), dentre as suas condicionantes à ocupação, faz recomendações como: a) atenção às políticas públicas em Itaboraí, pois uma vez finalizadas as obras, o COMPERJ gerará grandes expectativas de emprego; b) atenção às políticas públicas em São Gonçalo, que também sofrerá impactos decorrentes da implantação do COMPERJ; e c) atenção às políticas ambientais de Maricá (município também próximo ao COMPERJ), devido à falta de legislação municipal específica para reger suas áreas de vegetação nativa. Cabe ressaltar que estes mesmos municípios são citados no tópico seguinte: "Áreas definidas para uso industrial" pelas suas oportunidades locacionais de expansão no setor industrial. 
Nota-se que ao mencionar as áreas que ainda podem ser ocupadas na RMRJ, 0 PDAM estimula o uso industrial e condena a ocupação informal por população de baixa renda. Um exemplo desse discurso se dá no item "5.3. Desenvolvimento Econômico e Social”, no qual, ao analisar a “Área de Estudo 1", o Plano identifica a existência de várias indústrias que deverão ter o crescimento incentivado, falando inclusive que "ainda há 12,6\% de espaço disponível para atração de novos empreendimentos” (PDAM, 2011, p.493). No capítulo de diretrizes para "Disciplinamento do Uso e da Ocupação do Solo", o PDAM enfatiza a necessidade de propor aos municípios que os vazios urbanos lindeiros ao Arco sejam destinados à atividades industriais de baixo impacto e a serviços logísticos de apoio industrial.

Paralelamente, observamos que não há nenhum tópico específico para tratar da utilização de áreas vazias ou estoque de possíveis áreas públicas para futuramente implantar habitação de interesse social ou equipamentos sociais, seja de saúde, educação, lazer, etc.. Desta forma, as áreas vazias são primordialmente vistas como áreas voltadas para ocupação industrial ou outros tipos de expansão com fins econômicos, sem que seja apresentada possibilidade de áreas para uso habitacional dos trabalhadores destas indústrias.

Uma das poucas recomendações do PDAM quanto às questões sociais se restringe à necessidade de realização de investimentos em infraestrutura urbana devido à precária situação nesta área. Contudo, ao abordar as melhorias de infraestrutura, o PDAM deixa transparecer o interesse de que elas tenham rebatimento no setor industrial e no setor imobiliário voltado para as classes de alta renda.

No caso de Cachoeira de Macacu isso fica claro, uma vez que a recomendação fundamental é "a realização de investimentos para superar sua falta de infraestrutura para melhor escoamento da produção" (PDAM, 2011, p.551). Já a melhoria de infraestrutura de Maricá é vista como potencializadora da expansão do mercado imobiliário habitacional e da consolidação de um perfil turístico.

A presença do aeroporto e do heliporto, somado ao crescimento imobiliário e ao interesse de grandes construtoras e redes hoteleiras, pode gerar uma mudança no perfil do turismo na região.

Além disso, Maricá poderá se transformar, no futuro, numa clara opção de moradia para o COMPERJ, dado a questão aeroportuária e a qualidade das habitações em construção, desde que seja feito um esforço para cobrir o déficit de infraestrutura, principalmente na pavimentação, distribuição de água e coleta de esgotos (PDAM, 2011, p.558). 
Segundo o PDAM, alguns dados apontam que na RMRJ há uma considerável mobilidade entre local de moradia e local de trabalho. Niterói, por exemplo, é reconhecidamente uma cidade de moradia para classe média e alta. Isso ocorre devido ao fato de muitas pessoas que ali trabalham por baixos salários não conseguem moradia no municipio em decorrência da grande valorização da terra. Comumente, esses trabalhadores de Niterói moram no município vizinho, São Gonçalo. Já o município de Duque de Caxias possui salário médio mais alto do que Niterói, mas, vê seus trabalhadores de alto padrão indo morar em outros locais, como por exemplo o bairro da llha do Governador, na capital.

Por conta dessa realidade metropolitana fluminense, o Plano busca medidas para tentar evitar que os municípios que receberão grandes indústrias sejam locais de moradia apenas das classes baixas. Desta forma, o Plano passa a mensagem de que os municípios devem se esforçar para ficar em situação semelhante à de Niterói e evitar a de Duque de Caxias.

Com isso, o Plano volta a sua preocupação para as melhorias de infraestrutura básica a serem implantadas nos municípios para atender às demandas das classes mais altas, fazendo com que os problemas de infraestrutura deixem de ser um fator repelidor destas. Nesse contexto, há também uma preocupação com o fomento a atividades culturais e a estruturas de cunho ambiental que possam trazer benefícios turísticos que criem fatores atrativos para as classes altas.

Nota-se, assim, o estímulo a uma disputa entre os municípios. Vencerá aquele que conseguir atrair os futuros funcionários dos cargos de alta remuneração. Nessa competição, pouca atenção é dada para o acolhimento dos funcionários dos cargos de baixa remuneração.

Desta forma, no plano não há espaços para reflexões de escala regional, na qual ficaria claro que alguma área (deste ou daquele município) precisa ser destinada à absorção do contingente populacional de baixos salários. Assim, não detectamos no Plano a óbvia conexão do raciocínio de que, se nenhum município se planejar para recebê-los, fatalmente ocorrerá a "favelização" que o PDAM constantemente aponta como o mal a ser evitado.

Por um lado, o "boom imobiliário" no entorno do Arco é visto com bons olhos pelas grandes empresas de construção civil e do setor residencial de alta e média classe. Porém, por outro, a ocupação irregular dos terrenos por população de baixa renda é vista como um grande problema a ser combatido pelo governo do estado e municipalidades. 0 mesmo governo municipal que precisa combater a ocupação de terrenos por favelas é orientado 
também a dar condições de infraestrutura para a instalação de moradias para os trabalhadores dos mais altos salários.

logo na sua introdução, o PDAM (2011) se propõe a apontar soluções para desenvolvimento econômico e social, infraestrutura urbana, saneamento, habitação, transporte e mobilidade a partir de "projetos integrados". No o último capítulo, o Plano indica diretrizes para habitação de interesse social que parecem estar de fato preocupadas com uma resolução socialmente justa do problema habitacional. Este capítulo propõe, por exemplo, a construção de habitação de interesse social em áreas com boa localização, providas de infraestrutura adequada, com fácil acesso a serviços, ao local de trabalho, etc. No entanto, o Plano não desenvolve essas ideias, citando-as de forma muito breve.

O Plano ainda lembra que os programas habitacionais existentes têm permanecido subaproveitados, mas também não entra no debate de como criar estratégias para melhor aproveitá-los. Novamente, fazendo a análise quantitativa da abordagem do PDAM, vale observar que o tópico de diretrizes possui sessenta e sete páginas. Essas se distribuem da seguinte forma:

- 13 páginas para questões sobre a qualidade ambiental

- 3 páginas para ordenamento territorial

- 2 páginas para habitação

- 3 páginas para infraestrutura

- 4 páginas para desenvolvimento institucional e Governança

- 42 páginas para desenvolvimento Econômico e Social

Nas diretrizes, o tópico de "desenvolvimento Econômico e Social" novamente aborda basicamente o crescimento industrial e pouco trata das questões sociais. Ele detalha diretrizes para cada setor, tendo, por exemplo, subtópicos específicos para "Síntese das metas e ações para a Cadeia Naval e Estruturas Offshore". Deste modo, cabe questionar por que o PDAM é tão cuidadoso e detalhista com suas propostas para o setor industrial e, ao mesmo tempo, tão generalista e superficial nas suas propostas para infraestrutura e habitação.

Quando indagado sobre a inexistência de uma estratégia habitacional do PDAM, Ricardo Pontual (informação pessoal, 2014) ${ }^{72}$, coordenador da parte de Urbanismo do Plano, respondeu que a equipe de consultoria da qual ele fez parte elaborou simulações de

\footnotetext{
${ }^{72}$ Entrevista concedida no dia 06 de Abril de 2014, no Rio de Janeiro - RJ. Gravada em áudio, formato MPEG-4.
} 
"projetos integrados de habitação". Neles, seriam construídos habitações e comércio voltados para as diversas faixas de renda, e também seriam implantados infraestrutura básica, equipamentos de saúde, educação e lazer. Além disso, estes locais seriam conectados ao sistema de mobilidade urbana dos municípios. Assim, os chamados "projetos integrados" seriam, na prática, novos bairros completos nos municípios.

Ainda em relação a questão habitacional, o consultor acredita que o Programa Minha Casa Minha Vida não é uma boa solução para a região do entorno do Arco. Segundo Pontual (informação pessoal, 2014), este programa comumente promove habitação de forma estratificada, não mesclando as classes sociais, pois prevê a construção de habitações para as famílias de baixa renda em áreas afastadas dos centros urbanos, em locais de grande escassez de infraestrutura básica, de comércio e de equipamentos de saúde, educação e lazer

0 Minha Casa Minha Vida continua estratificando a oferta habitacional por segmento social sem integrar nada. Não só se espalhando pelo subúrbio, lugar onde não tem transporte, não tem nada, como segmentando essas famílias, isolando essas famílias de tudo. 0 projeto integrado é justamente para dar uma alternativa de que aquilo cresça como bairro, com todas as facilidades, com comércio, etc. (PONTUAL, informação pessoal, 2014).

Pontual (informação pessoal, 2014) afirma que nos relatórios parciais entregues à administração pública pela equipe de consultoria de urbanismo, há vários modelos de projetos integrados de habitação. Além disso, ele conta que foram pensadas alternativas para que esses projetos fossem viabilizados em parcerias com empresas privadas ou até com proprietários da terra de forma a construir bairros completos antes da especulação e da supervalorização dos terrenos. Segundo o consultor, essa é uma forma mais funcional do que a criação de um banco de terras.

Ele expõe que, desde a época em que ele trabalhava no Banco Nacional de Habitação (BNH), a estratégia de estoque de terras nos municípios do Rio de Janeiro não funcionava. Pontual conta que já foi um defensor da criação de banco de terras, mas que essa estratégia acaba sendo muito onerosa. Os terrenos ficavam muito tempo vazios, e eram enormes os gastos com guardas para evitar invasões. Segundo ele, mesmo quando um município consegue manter o terreno vazio até a data de início da obra, comumente ele não consegue impor o uso dessa terra às construtoras, por conta da força dos agentes imobiliários.Assim, para ele, a melhor solução seria atuar logo no início das obras e em conjunto com os setores privados para a criação desses projetos integrados. 
Pontual (informação pessoal, 2014) ${ }^{73}$ comenta que não chegaram a mapear todas as áreas da RMRJ possíveis para realizar tais "projetos integrados”. Fizeram apenas uma gama de exemplos, para mostrar que era possível a aplicação em diferentes áreas. Contudo, esses estudos não entraram no relatório final do Plano. Na entrevista, o consultor disse não saber o motivo dessa exclusão.

No relatório final do Plano, consta apenas a visão de habitação de baixa renda como foco de pobreza e violência. Nas palavras do PDAM, "são antevistos riscos de aumento dos níveis de violência urbana, caso se intensifiquem processos de favelização e de ocupações subnormais na região, gerando novos focos de concentração de pobreza” (PDAM, 2011, p.561).

Para o Plano, além da violência, o provável crescimento populacional, caracterizado por setores de baixa renda que buscam as novas possibilidades de emprego, também agravarão os problemas de infraestrutura urbana.

Os serviços de saneamento ambiental - água, esgoto, drenagem urbana e resíduos sólidos - também deverão sofrer aumento das demandas, em decorrência do aporte de população ou mesmo mudança espacial de concentrações populacionais, e em virtude da implantação de grandes empreendimentos industriais.

A questão do abastecimento de água pode se tornar crítica em alguns municípios da Baixada Fluminense em que os níveis de cobertura dos serviços ainda são baixos, tais como em Mesquita e Nova lguaçu. (...) Quanto à coleta e tratamento de esgotos, a situação é ainda mais grave, pois o nível de cobertura dos serviços é muito baixo, repercutindo negativamente na qualidade da água da rede de drenagem e mesmo de mananciais de abastecimento público"(PDAM, 2011, p.561).

O RIMA (2007) adverte que o problema de "violência, favelização e desemprego", já comum em centros urbanos, também atinge as áreas de influência do Arco. Entretanto, o relatório de impactos associa esses problemas à perda do dinamismo econômico da RMRJ que vem ocorrendo nas últimas décadas e à consolidação de muitos municípios da metrópole como “cidades dormitórios”. Assim, a dinamização econômica prevista com a implantação do Arco e dos Empreendimentos Estruturantes supra citados é assinalada como uma oportunidade de alterar esse quadro regional. 


\subsection{Meio ambiente}

Ao apresentar o uso e ocupação do solo da área de influência do Arco, o Plano dá uma visão geral de todo esse espaço que apresenta $46 \%$ da região encoberta por Ecossistemas Naturais e 26\% destinada a uso agropastoril, tendo apenas 22\% de área urbanizada e 1\% com outros usos (praias, afloramentos rochosos, etc.).

Tal área é formada por ecossistemas naturais essenciais para a proteção de: mananciais hídricos; rios; encostas e regulação da temperatura local. Por conta disso, o PDAM (2011) destaca a relevância dessas áreas na proteção da qualidade de vida silvestre e humana. Pela tabela abaixo podemos ver que todos os municípios cortados pelo Arco têm a maior fração da sua área ocupada por usos agropastoris e/ou florestais (figura 40).

\begin{tabular}{lrrr}
\hline \multicolumn{1}{c}{ Município } & Agropastoril\% & Floresta $\%$ & Urbano $\%$ \\
\hline São João de Meriti & $6 \%$ & $0 \%$ & $94 \%$ \\
\hline Belford Roxo & $26 \%$ & $12 \%$ & $62 \%$ \\
\hline Nilópolis & $47 \%$ & $2 \%$ & $51 \%$ \\
\hline Rio de Janeiro & $17 \%$ & $32 \%$ & $49 \%$ \\
\hline São Gonçalo & $27 \%$ & $27 \%$ & $46 \%$ \\
\hline Niterói & $8 \%$ & $45 \%$ & $41 \%$ \\
\hline Mesquita & $15 \%$ & $53 \%$ & $34 \%$ \\
\hline Duque de Caxias & $22 \%$ & $50 \%$ & $27 \%$ \\
\hline Queimados & $66 \%$ & $5 \%$ & $25 \%$ \\
\hline Japerí & $60 \%$ & $18 \%$ & $22 \%$ \\
\hline Nova Iguaçu & $26 \%$ & $52 \%$ & $22 \%$ \\
\hline Maricá & $20 \%$ & $57 \%$ & $18 \%$ \\
\hline Itaboraí & $60 \%$ & $23 \%$ & $16 \%$ \\
\hline Itaguaí & $42 \%$ & $43 \%$ & $14 \%$ \\
\hline Magé & $23 \%$ & $65 \%$ & $11 \%$ \\
\hline Seropédica & $71 \%$ & $11 \%$ & $11 \%$ \\
\hline Tanguá & $59 \%$ & $33 \%$ & $7 \%$ \\
\hline Guapimirim & $34 \%$ & $58 \%$ & $6 \%$ \\
\hline Paracambi & $53 \%$ & $43 \%$ & $3 \%$ \\
\hline Mangaratiba & $10 \%$ & $87 \%$ & $2 \%$ \\
\hline Cachoeiras de Macacú & $27 \%$ & $71 \%$ & $1 \%$ \\
\hline
\end{tabular}

Figura 40 - Percentual de cobertura de uso do solo Agropastoril, Florestal e Urbano dos Municípios da área de influência do Arco Metropolitano em 2007. Fonte: (PDAM, 2011,p.399) (grifo nosso).

Assim, o PDAM (2011) afirma que o planejamento metropolitano deve respeitar essas áreas para compatibilizar o crescimento econômico com os princípios ambientais. Como outros empreendimentos que vêm sendo realizados nos últimos anos, o Plano Diretor do Arco Metropolitano também pretende ser um instrumento que visa ao desenvolvimento sustentável. Até a data da sua publicação, o PDAM era chamado de "Plano Diretor Estratégico de Desenvolvimento Sustentável do Arco Metropolitano do Rio de Janeiro". Logo na sua apresentação, o PDAM diz que "permitirá ao Governo do Rio de Janeiro a 
efetiva coordenação do desenvolvimento sustentável de toda a área de influência do Arco Metropolitano" (PDAM, 2011, p.2).

Ao descrever a cobertura vegetal ao longo do Arco, o RIMA (2007) aponta a existência de fragmentos florestais que serão seccionados parcialmente ou totalmente pela rodovia, fazendo menção, por exemplo, ao caso da Floresta Nacional Mário Xavier. 0 Relatório também comenta a conflituosa relação entre as manchas urbanas e as manchas de vegetação das Unidades de Conservação.

Conforme já comentado no capítulo 1, segundo Ferreira e Ferrara (2012), o processo de urbanização e de industrialização esteve historicamente ligado ao aumento dos impactos ambientais.Segundo Machado(2003), a ausência de uma visão ambiental de preservação dos ecossistemas na época da construção da grande maioria das rodovias brasileiras foi a grande causadora dos danos ambientais nos corredores viários existentes. Tais danos geram até hoje enormes passivos ambientais legados às gerações futuras.Ao abordar o caso da BR-101N (Niterói - Manilha), construída em 1974, também no estado do Rio de Janeiro, Pinto (2010) descreve relevantes processos de degradação ambiental que envolveram, entre outros: os danos ao ecossistema manguezal, o desaparecimento de praias e, em decorrência, a drástica diminuição de atividades de catação de caranguejo e pesqueiras.

Diante desse cenário de provável degradação ambiental, acreditamos que a construção de uma rodovia é uma decisão política que deve ser debatida com a população. Uma vez decidido implantar a rodovia, é necessário realizar um planejamento que trate de questões ligadas à temática ambiental da nova via apontando saídas para os conflitos entre urbanização e preservação. Contudo, no PDAM (2011) percebemos em muitos momentos que essa abordagem é feita de forma a respaldar a possibilidade de um forte crescimento industrial concomitante a uma melhora ambiental.

0 Estado do Rio de Janeiro participa desse movimento, com programas de vigoroso recrudescimento econômico, ao mesmo tempo em que fortalece sua conduta ambiental, cuidando de seus recursos naturais na perspectiva de processos sustentáveis. (PDAM, 2011, p.3).

Assim, analisaremos aqui algumas das decisões públicas tomadas sobre como construir a rodovia, para mostrar que no caso do Arco tais conflitos não só existem, como as suas resoluções privilegiaram outros fatores que não a questão ambiental. Mostraremos a seguir que em determinados momentos, havia alternativas para construir a rodovia causando um menor impacto ambiental negativo. Contudo, essas alternativas foram preteridas. 
Para análise do debate ambiental que envolve o Arco apresentaremos primeiramente os impactos ambientais gerados inicialmente pela obra e posteriormente os impactos que se darão no decorrer do tempo de operação desta rodovia.

\subsubsection{Pressões ambientais da obra}

No decorrer dos sete anos da obra, destacamos três casos emblemáticos sobre os impactos ambientais da construção da rodovia: a falta de matéria-prima, a ameaça à rã Physalaemus Soaresi e a ameaça ao peixe Notholebias Minimus, ambos endêmicos da Floresta Nacional (FLONA) Mário Xavier.

\section{A falta de matéria-prima}

No início de agosto de 2011, o governador Sergio Cabral publicou no Diário Oficial um decreto que tornou de interesse social um terreno de 23,3 hectares na região de Barão de Guandu. Este terreno se localizava no município de Nova lguaçu e estava demarcado anteriormente como Área de Preservação Permanente (APP). Segundo notícia do jornal 0 GLOBO (BERTA, 2011), o objetivo dessa liberação do uso do solo seria a utilização deste espaço como local para o desmonte de saibro para o abastecimento do lote 1 do Arco Metropolitano.

Pouco dias depois, outro caso demonstra a falta de matéria-prima para a construção do Arco. Desta vez foi noticiado a extração ilegal de argila comandada por milicianos na região de Santa Cruz (O GLOBO, 2011). Segundo o delegado Fábio Scliar, da Delegacia de Meio Ambiente da Polícia Federal do Rio, a argila era comprada por empreiteiras contratadas para executar as obras do Arco Metropolitano. Na época, o delegado não tinha certeza se as empresas sabiam que estavam adquirindo material ilegal e também não divulgou os nomes das empresas. 


\section{Argila ilegal extraída por milícia de Santa Cruz parava no Arco Metropolitano, informa Polícia Federal}

Figura 41 - Extração ilegal de argila que abastecia obras do arco. Fonte: O GLOBO (2011).

Um ano depois, o Jornal do Brasil (MELLO, 2012) noticiou a saída da Delta do consórcio que executaria um lote do trecho 'C' do AMRJ. Uma das razões alegadas pela empresa para nem sequer ter iniciado as obras desde a assinatura do contrato em 2010, foi a falta de matéria-prima. Nesta mesma reportagem, o periódico declarou que havia rumores de que a Delta teria sido surpreendida pela Polícia Federal tentando comprar ilegalmente areia com milicianos.

Durante os mais de dois anos sem iniciar a obra, o consórcio capitaneado pela Delta usou diversos motivos para justificar o atraso. As explicações variaram da falta de licenciamento ambiental, por conta de uma espécie de pererecas ameaçada de extinção que foi encontrada na área, até à falta de reserva de jazidas para o fornecimento de areia para o empreendimento.

Tudo isto, segundo o próprio DNIT, gerou um "desequilíbrio financeiro". Há informações, inclusive, de que a Delta teria sido surpreendida pela Polícia Federal tentando comprar areia, ilegalmente,com milícias de Itaguaí, na Baixada Fluminense, para utilizar nas obras do Arco Metropolitano. (MELLO, 2012)

Em nota publicada no mesmo jornal, dias depois, a Delta se defendeu afirmando que "Toda aquisição de material e equipamentos é realizada em acordo com a legislação, atendendo aos princípios éticos, através de fornecedores legalizados. Portanto, é leviana a informação de compra de areia por meios escusos" (AULER, 2012).

Analisando comparativamente imagens de satélite da construção do segmento "C" do AMRJ, datadas entre os anos de 2008 e 2015, notamos que podem ser percebidas novas áreas de desmatamentos para extração mineral. É provável que algumas dessas áreas tenham sido abertas justamente para atender à necessidade de materiais para a construção do AMRJ, dada a proximidade dessas áreas com a obra. Duas delas, inclusive, possuíam ligação direta com a construção da rodovia, conforme mostrado nas quatro imagens a seguir. Nessa pesquisa não tivemos elementos que possibilitassem verificar se o processo de extração nessas áreas se deu de forma totalmente legal. Limitamo-nos assim a somente identificá-las. 
A figura 42 mostra um trecho do município de Seropédica em que o AMRJ passará próximo da estrada RJ-125. Nesta imagem, podemos observar (marcados em amarelo) o aumento de uma área de extração mineral existente e o surgimento de dois novos pontos. Ainda nesta figura, a seta vermelha indica o ângulo da figura $43^{74}$, onde vemos a construção do Arco à direita e o acesso direto com a referida área de extração.

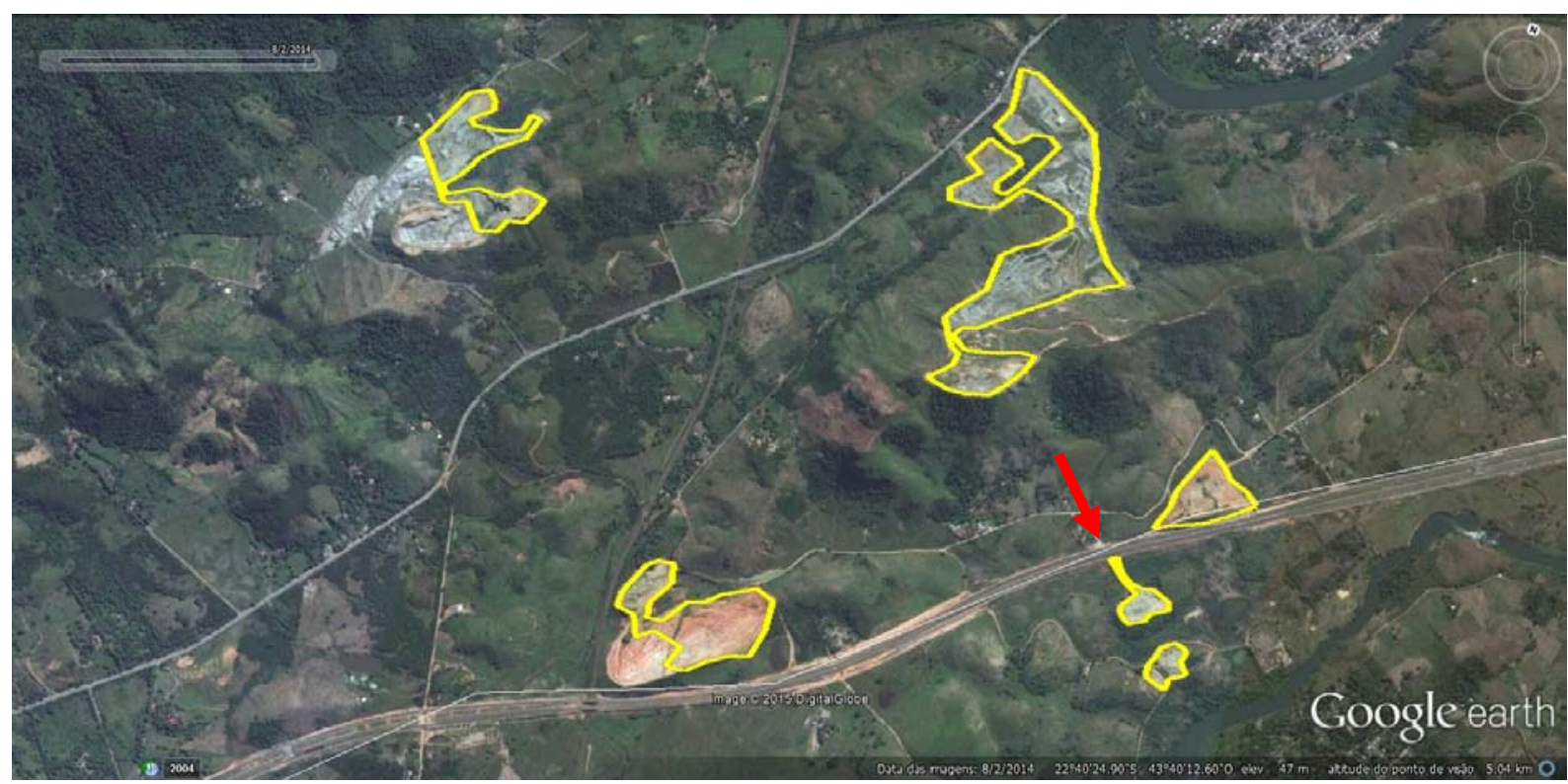

Figura 42 - Áreas desmatadas para extração mineral em Seropédica (surgimento entre 2008 e 2015). Fonte: Elaboração própria com base em imagens do Google Earth, 2015.

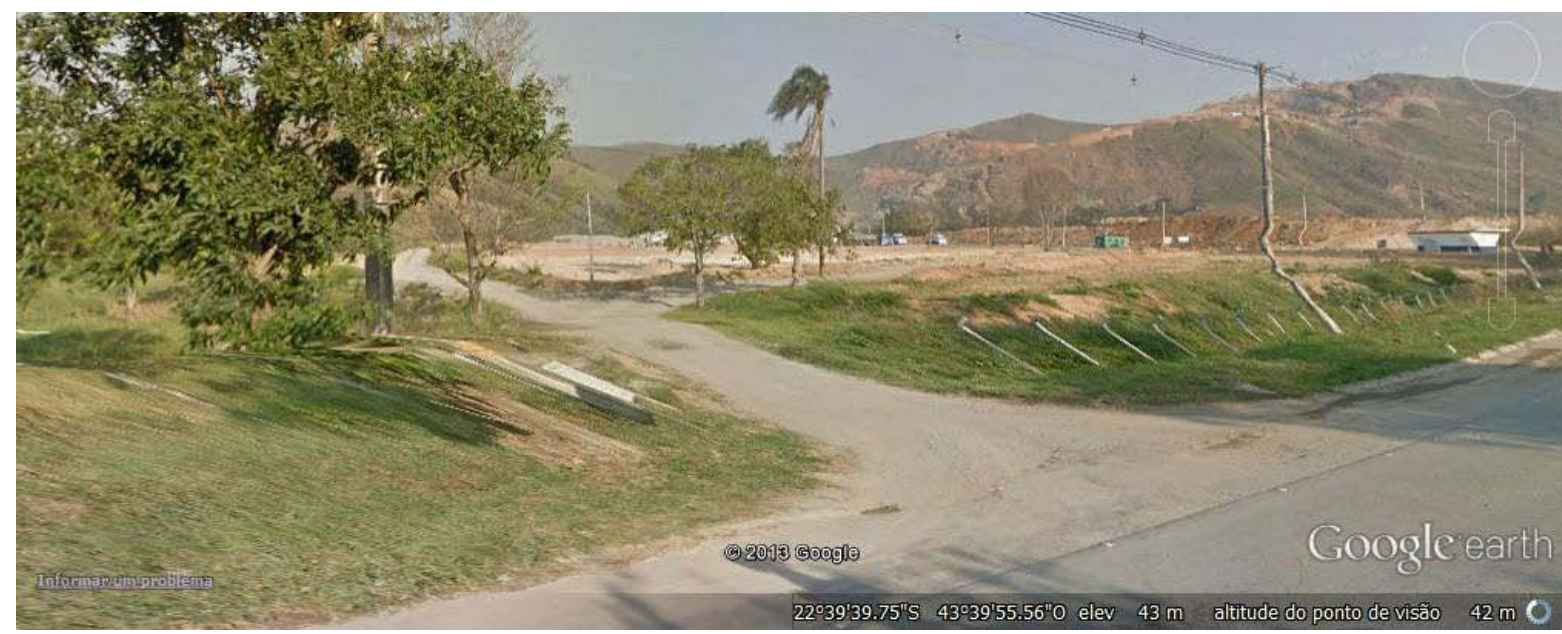

Figura 43 - Entrada da área de extração mineral em Seropédica (local marcado na figura 42). Fonte: Imagem do Google Earth, 2013.

Em outro trecho do município de Seropédica, próximo à rodovia Presidente Dutra (BR-116), a mesma situação se repete. A figura 43 está indicando (em amarelo) mais um

\footnotetext{
${ }^{74}$ Esta figura é uma foto tirada para o mecanismo de visualização streetview do software Google Earth.
} 
ponto de extração mineral surgido entre fevereiro e julho de 2011. Também foi possível identificar um caminho que liga a área diretamente desmatada a um trecho do AMRJ que está em obras. A figura 44 é uma foto ${ }^{75}$ (ângulo indicado por seta vermelha) do trecho em que o Arco cruza com a RJ-116. Nela, é possível identificar a entrada desse caminho que leva à área de extração. Parte dessa área, ainda aparece ao longe, atrás das árvores que ficam do lado esquerdo da foto.

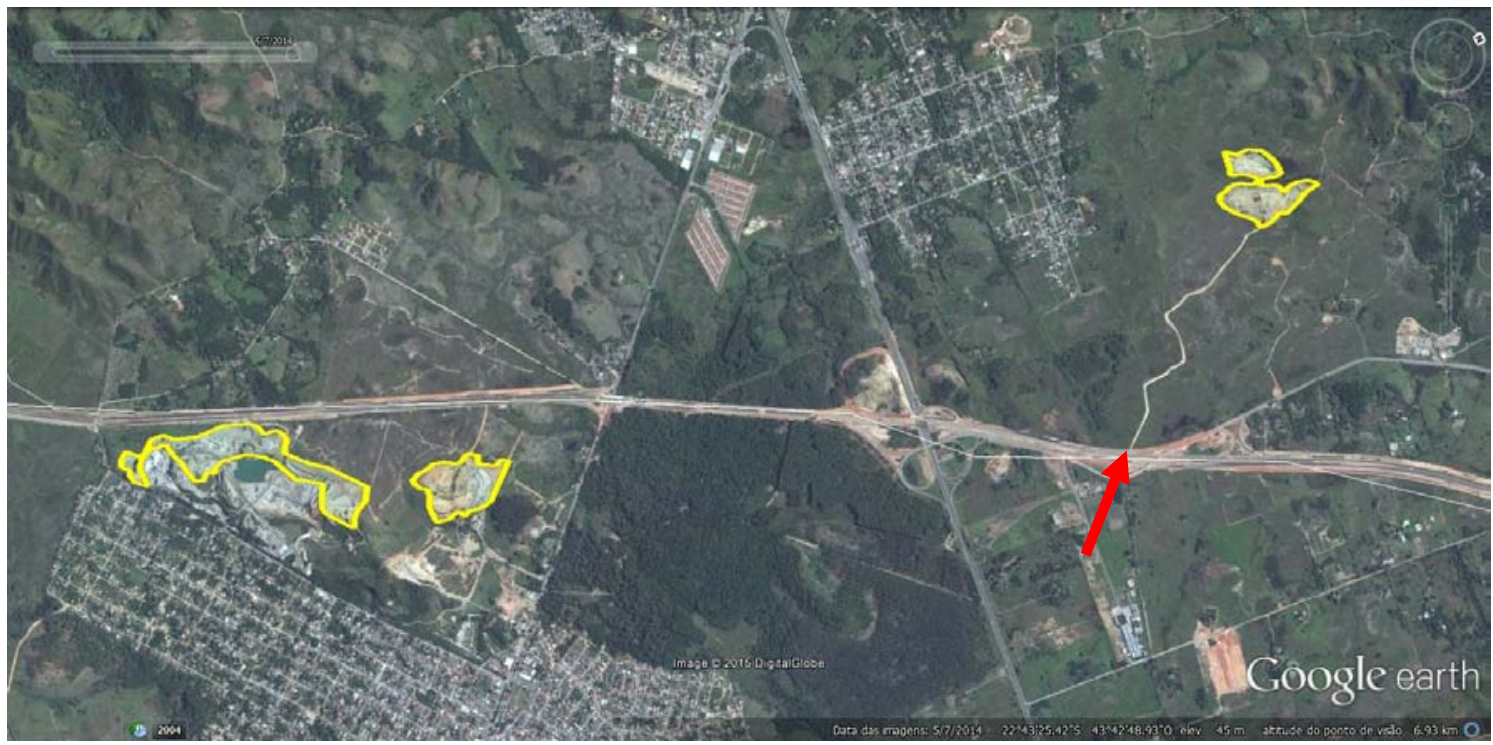

Figura 44 - Áreas desmatadas para extração mineral vinculada ao AMRJ. Fonte: Elaboração própria com base em imagens do Google Earth, 2015.

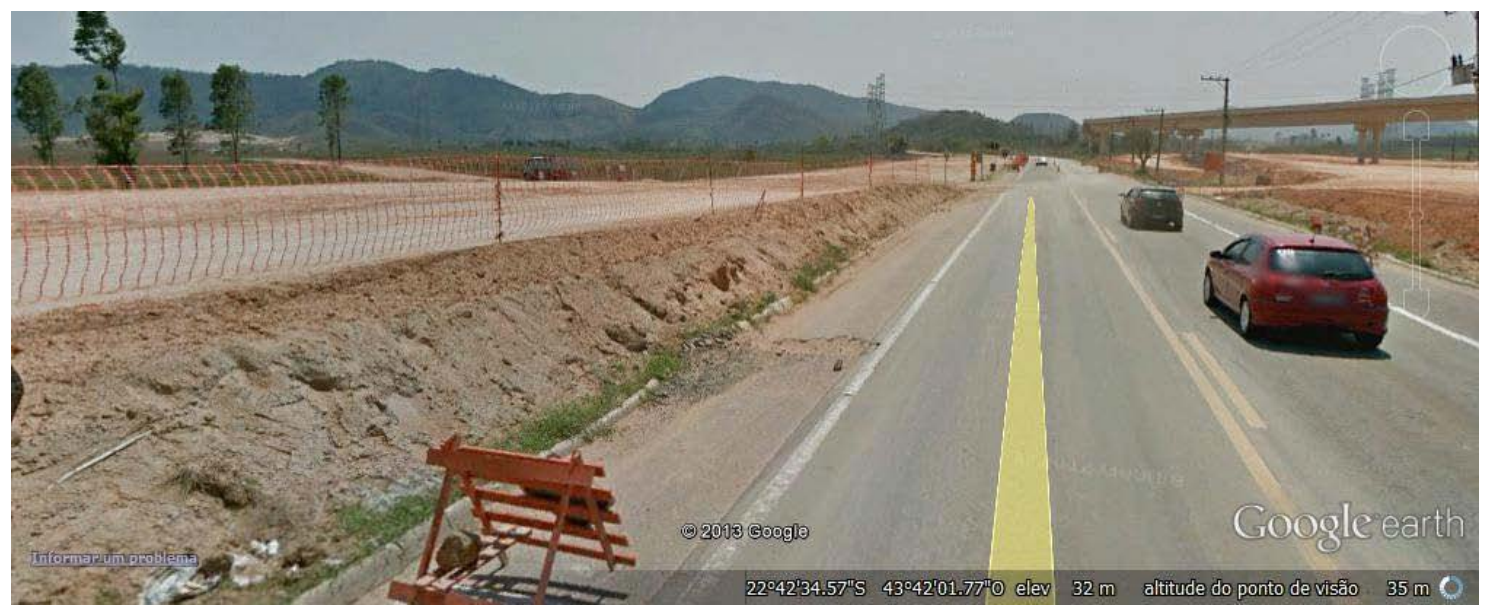

Figura 45 - 0 acesso direto ao AMRJ da área desmatada marcada na figura 44. Fonte: Elaboração própria com base em imagens do Google Earth, 2013.

Em outros trechos, como na rodovia Prefeito Abeilard Goulart de Souza (RJ-099), percebemos o aumento dos lagos artificiais, oriundos da exploração de areia. A imagem

\footnotetext{
${ }^{75}$ Tirada para o mecanismo de visualização streetview do software Google Earth, 2015.
} 
abaixo marca em amarelo todos os lagos que não existiam em 2006 e passaram a existir em 2014. Essas áreas distam cerca de dez quilômetros do Arco.

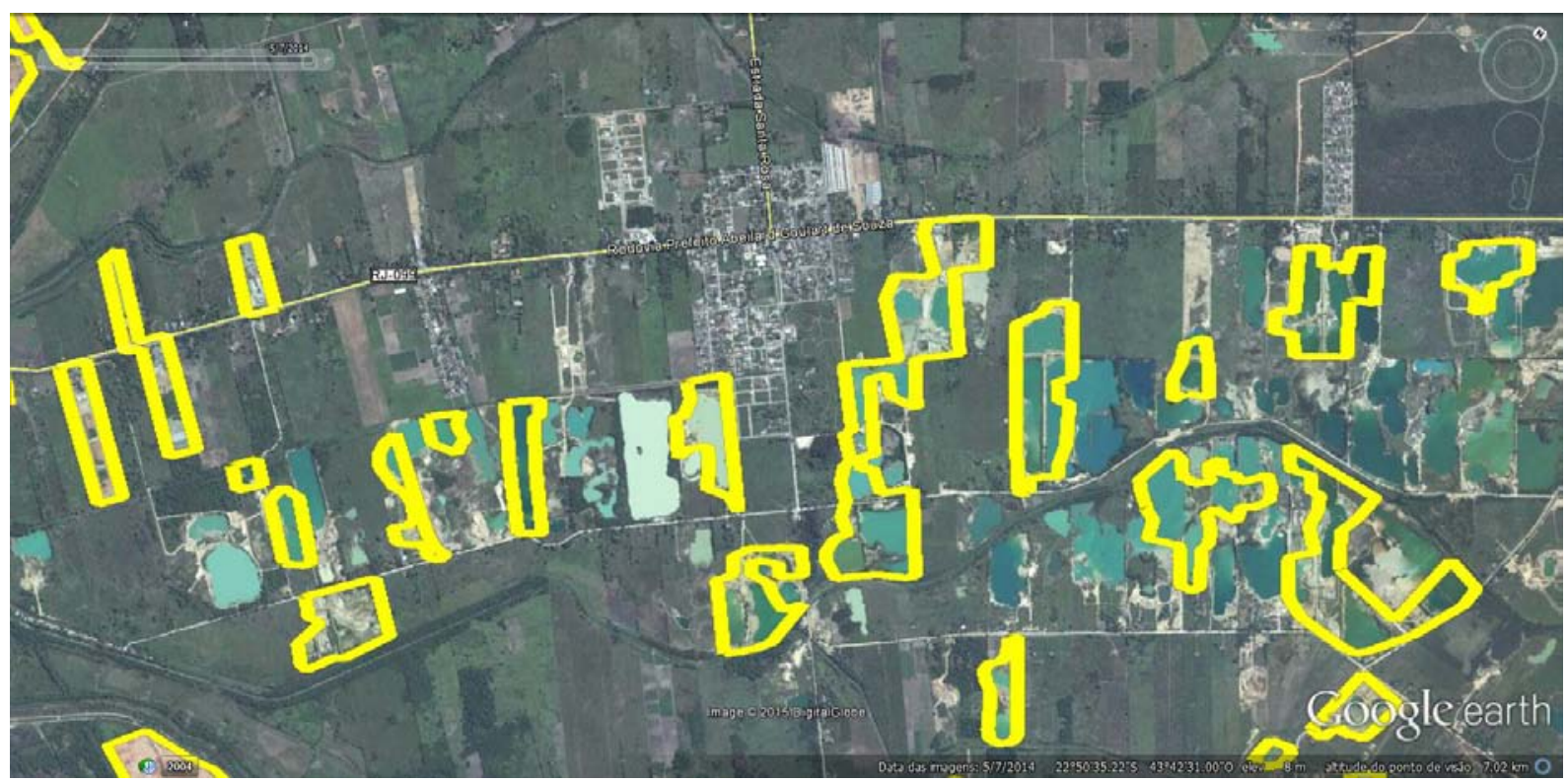

Figura 46 - Áreas desmatadas para extração mineral. Fonte: Elaboração própria com base em imagens do Google Earth, 2015.

\section{0 caso da rã}

Conforme veremos mais detalhadamente na figura 53, o Arco Metropolitano corta a Floresta Nacional (FLONA) Mário Xavier, ameaçando assim a biodiversidade ali existente. Em julho de 2009, foram encontradas na FLONA Mário Xavier, perto das obras do Arco, algumas pequeninas rãs da espécie Physalaemus Soaresi, já ameaçada de extinção. "A perereca foi descoberta na década de 1960. Pesquisas mostram que ela não existe em nenhuma outra área a não ser naquela reserva específica” - explicou o biólogo Sérgio Potsch, responsável pelo laboratório de répteis e anfíbios da Universidade Federal do Rio de Janeiro ao Portal de notícias G1 (MENDONÇA, 2009).

A primeira proposta governamental noticiada foi a criação de um "bichoduto" que permitiria a passagem da espécie de rã por debaixo da rodovia. Contudo os técnicos do Instituto Brasileiro do Meio Ambiente e dos Recursos Naturais Renováveis (IBAMA) não estavam seguros de que esta seria uma solução eficiente. Criou-se, então, um impasse entre o presidente da época, Luiz Inácio Lula da Silva, e os técnicos do IBAMA. 


\title{
Lula volta a reclamar da 'perereca' que atrasa obras
}

\author{
POR LEILA SUWWAN - ENVIADA ESPECIAL /// \\ Figura 47 - Notícia sobre o conflito envolvendo a rã. Fonte: SUWWAN, 2010.
}

Na época, o professor e criador do curso de Biologia da Universidade Federal Rural do Rio de Janeiro, lzekson (in RURAL SEMANAL, 2009) parabenizou a ação do IBAMA no caso e desaprovou o tom de ironia com que o assunto estava sendo tratado pela mídia. Ele comentou que a extinção de uma espécie é algo definitivo, e a impossibilidade de pesquisar sobre uma espécie implica na eterna inviabilização da aplicação de um conhecimento. 0 professor lembra que "uma espécie de perereca, de rã ou de sapo pode conter informações valiosíssimas para salvar a vida de muita gente e a sua proteção e conservação é sempre muito mais importante para o ser humano do que um viaduto, um túnel, uma estrada" (IZEKSON, in RURAL SEMANAL, 2009,p. 2).

0 posicionamento do ex-presidente da República Luiz Inácio Lula da Silva sobre a demora da liberação do IBAMA também foi criticado por Célio Haddad, especialista em anfíbios e professor da Universidade Estadual Paulista Júlio de Mesquita Filho (UNESP). Haddad (in BOURSCHEIT, 2009) expôs o impasse entre conhecimento científico e o dito “desenvolvimento nacional”. Segundo ele, o tempo de pesquisa do IBAMA é fundamental para que se possa ter argumentos sólidos que determinem a proteção ambiental. Assim, ele argumenta que "muita coisa é exterminada antes de ser conhecida. lsso é uma irresponsabilidade, mas travar o conhecimento é fundamental para que não haja elementos para se evitar a degradação. Você só consegue proteger bem aquilo que você conhece" (HADDAD, in BOURSCHEIT, 2009).

Para estes especialistas em anfíbios, a passagem do Arco na área em que foi encontrada a rã em questão, a Physalaemus Soaresi, é extremamente grave por diversos fatores. Entre eles, destacaremos aqui os dois mais relevantes.

0 primeiro é que essa rã, até hoje, só foi encontrada nessa área, apesar de ser um anfíbio com voz muito característica e que pode ser ouvido a uma centena de metros, conforme indica lzekson, primeiro cientista a descrever essa espécie em 1965. Outros especialistas também ressalvam que, ainda que se tomem medidas mitigadoras, a manutenção da rodovia neste local é, por si só, um impacto suficiente para extinguir a espécie rara de rã. 
Haddad (in BOURSCHEIT, 2009) vai além e alerta que a passagem do Arco na FLONA se configura como um crime ecológico de responsabilidade das instituições públicas envolvidas no caso. Para ele, esta situação é um caso de desrespeito à legislação. Sendo assim, alguém deveria pagar seriamente pela extinção da espécie. 0 pesquisador ainda sugeriu que o local fosse "transformado em um tipo de reserva onde não se poderia mexer, protegendo aquela e outras espécies" (HADDAD, in BOURSCHEIT, 2009, p.1).

0 segundo fator diz respeito à importância dos anfíbios na pesquisa de remédios para as doenças dos seres humanos. Izekson (in RURAL SEMANAL, 2009) explica que as rãs têm secreções na pele que servem como defesa contra predadores, fungos, bactérias, vírus e protozoários, pois possuem a pele nua e úmida e vivem em locais também muito úmidos. Segundo o pesquisador, cada espécie de rã produz as suas substâncias químicas exclusivas que estão sendo pesquisadas em todo o mundo, inclusive aqui no Brasil. Ele ressalta que algumas dessas substâncias detectadas na pele de anfíbios podem ser capazes de matar protozoários existentes no sangue humano, e se forem devidamente sintetizadas, podem, por exemplo, resolver o gravíssimo problema da Doença de Chagas, que assola milhões de brasileiros.

De acordo com Haddad (in BOURSCHEIT, 2009), os compostos ativos da pele da Physalaemus Soaresi jamais foram estudados. Assim, Potsch (2009) lembra que: “A lei está sendo desrespeitada e poderemos perder uma chance de fazer achados importantes. Hoje, estamos descobrindo substâncias úteis em espécies pouco estudadas“ (POTSCH in BOURSCHEIT, 2009, p.2).

Segundo MENDES (2011), após essa polêmica, foram propostos dois viadutos sobre a área onde vivem os animais ameaçados de extinção e também a construção de cercas vivas para reduzir o ruído e a carga de fumaça emitida pelos carros. Contudo, de acordo com Rocco (in MENDES, 2010), a ideia dos viadutos com um "bichoduto" foi aceita pelos técnicos do Instituto Chico Mendes de Conservação da Biodiversidade (ICMBio) ${ }^{76}$ mas,para eles, essa é uma solução apenas mitigadora, sem representar a eliminação total do impacto ambiental, que só poderia ser atingida com a passagem da rodovia por fora da FLONA.

Potsch (in MENDONÇA, 2009) também acredita que essa é apenas uma solução paliativa. Para ele, o barulho e a poluição dos veículos que passarão diariamente na rodovia

\footnotetext{
76 Autarquia vinculada ao Ministério do Meio Ambiente cuja finalidade é executar as ações do Sistema Nacional de Unidades de Conservação, podendo propor, implantar, gerir, proteger, fiscalizar e monitorar as UCs instituídas pela União. Fonte: <http://www.icmbio.gov.br/portal/quem-somos/o-instituto.html>, último acesso em janeiro de 2015.
} 
poderão interferir na vida e na reprodução da espécie, pois ela tem uma audição muito sensível. Com isso, quanto aos "bichodutos", o pesquisador lembra que provavelmente eles serão extremamente barulhentos, devido ao ruído causado pelos veículos pesados que trafegarão em cima desses dutos. Este pesquisador também destaca que a desova dessa rã se dá pela fabricação de uma espécie de espuma e ressalta que a poeira da rodovia poderá contaminar essa espuma e também a água onde vivem esses animais. Assim, segundo ele, ainda não é possível calcular qual tipo de interferência a rodovia ocasionará na colônia de rãs.

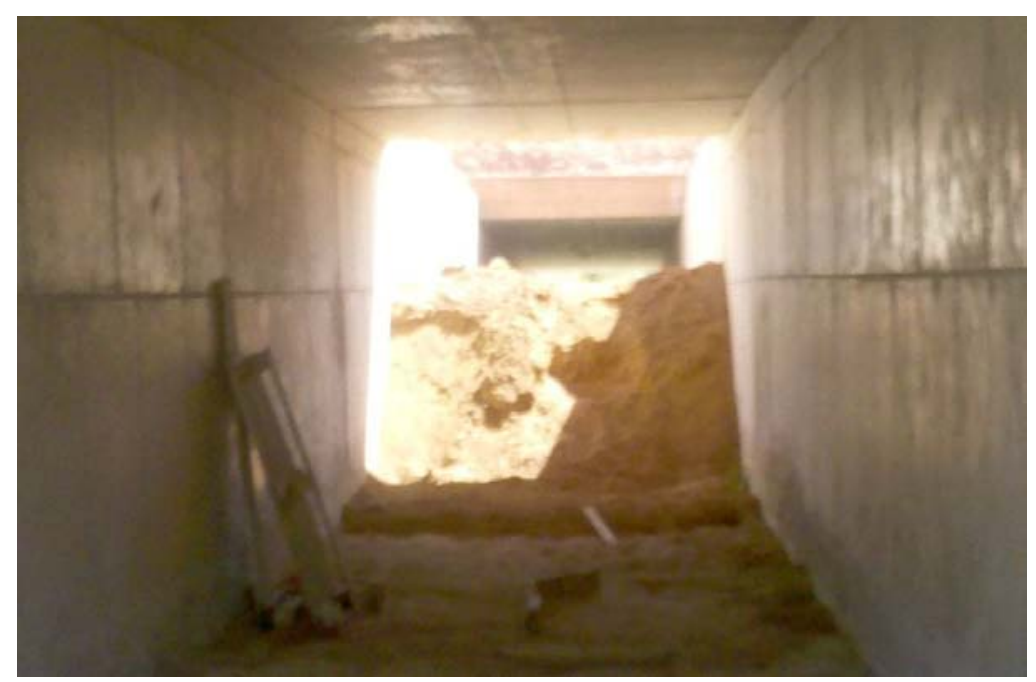

Figura 48 - 0 Bichoduto durante a obra. Fonte: acervo pessoal de Ticianne R. de Souza, foto de 16/05/2014.

Em visita de campo, pudemos constatar que, durante a obra, os bichodutos (figura 48) não cumpriam a sua função. No local encontramos ferramentas da obra e montes de argila com cerca de um metro e oitenta centímetros de altura, que bloqueavam a passagem dos animais. Segundo o funcionário da FLONA que acompanhava a visita essa situação era constante.

Também constatamos que um trecho (figura 49) da floresta estava sendo assoreado por chuvas que levavam areia da obra para dentro de uma poça onde foram encontradas rãs da espécie Physalaemus Soaresi. Além da areia, havia na poça peças de prisma de concreto que caíram da pista e outras peças que estavam prestes a cair. 


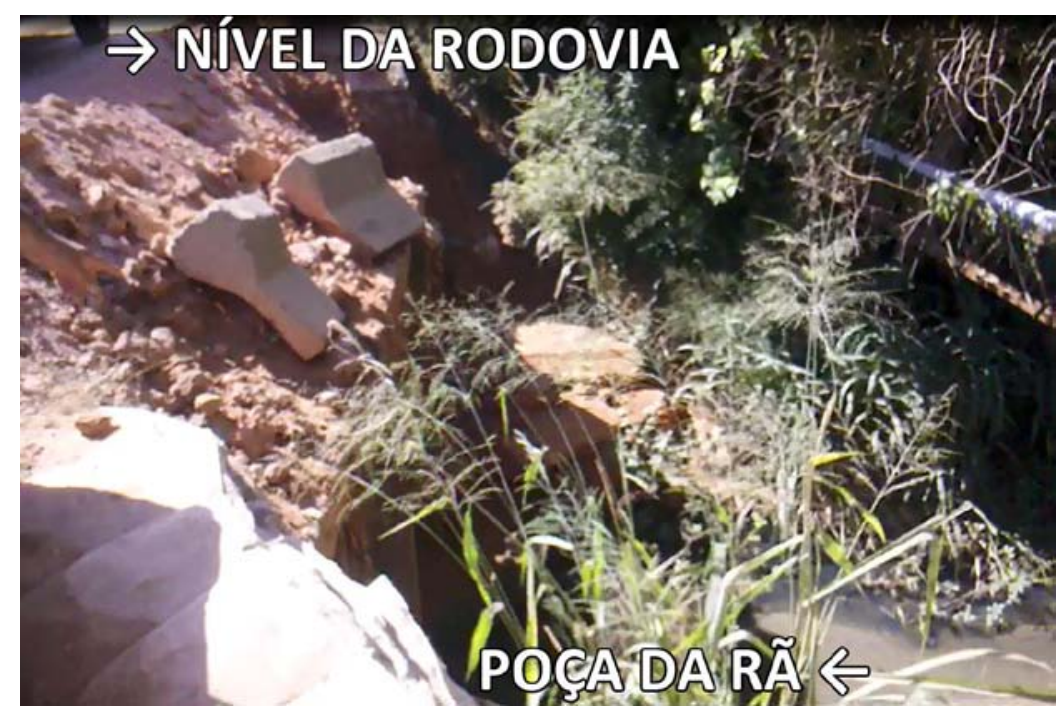

Figura 49 - Assoreamento em poça da Physalaemus Soaresi. Fonte: acervo pessoal de Ticianne Ribeiro de Souza, foto de 16/05/2014.

\section{0 caso do peixe}

Dois meses depois da descoberta da rã, na mesma floresta foi descoberta a presença do peixe Notholebias Minimus, o que dificultou ainda mais a retomada da obra no local. Bourscheit (2009b) critica o Estudo e Relatório de Impacto Ambiental do Arco Metropolitano, que não menciona em nenhum momento a existência da ameaçada rã Physalaemus Soaresi. Porém, destaca que o EIARIMA reconhece a existência do peixe-dasnuvens (Leptolebias Minimus) na FLONA, lembrado, no próprio documento, como sendo "endêmico do Rio de Janeiro e reconhecido como vulnerável na lista de espécies ameaçadas de extinção do Estado do Rio de Janeiro".Contudo, segundo o biólogo Nielsen (in BOURSCHEIT, 2009b),podem existir no local cinco espécies parecidas de peixe. Assim, ele recomendou a revisão do RIMA no que tange à proteção da ictiofauna.

Segundo o ex- diretor de Conservação da Biodiversidade do Instituto Chico Mendes (in BOURSCHEIT, 2009b), uma análise preliminar do caso dessas espécies em extinção indicou que o Arco não ameaça nem o peixe (Leptolebias Minimus) nem a rã (Physalaemus Soaresi), já que a ocorrência dos mesmos se dá em local distante do traçado do Arco.Já para o professor Pereira (in BOURSCHEIT, 2009b), há um descaso histórico do governo com a preservação nessa área. De acordo com ele, o Arco é uma ameaça às espécies, ainda que a rodovia não passe exatamente em cima do seu habitat natural. Ele ainda ressalta que o próprio Estudo de Impacto Ambiental da obra reconhece essa possibilidade, afirmando que 
"a fauna silvestre pode sofrer impactos diversos devido ao ruído e poluição, tais como emigração, inibição da natalidade, etc.” (in BOURSCHEIT, 2009b).

Pereira (in BOURSCHEIT, 2009b) discorre sobre o descaso dos governantes e também levanta uma possível armação entre entidades nacionais para violar as normas ambientais e viabilizar a obra. Ele ainda ressalta que houve uma opção pelos custos ambientais aos custos financeiros, na qual se optou por uma ação de menor aporte financeiro, que extermina espécies raras para atender aos interesses do empreendedor. 0 professor lembra também que essas espécies aparecem como ameaçadas de extinção na lista vermelha da União Internacional para Conservação da Natureza. Portanto, é um problema internacional de conservação. Assim, ele aponta que este caso demonstra um absurdo distanciamento entre a academia e as instâncias governamentais de conservação.

Em reportagem da Agência Brasil (2012), o coordenador regional do 1CMBio Luis Felipe de Luca declarou que vinha trabalhando na composição de alternativas de estrutura do traçado para garantir as espécies locais. No entanto, segundo a matéria, ele teria dito que diante da dificuldade de inviabilizar uma estrada de importância estratégica regional e nacional, o instituto entendeu que poderia ser dada uma autorização para o início das obras.

Mostrando o conflito, a Agência Brasil (2012) também traz o depoimento do vicepresidente da Associação de Moradores do Bairro Esperança, vizinho à Floresta Nacional Mário Xavier, em Seropédica, Antônio Félix de Oliveira. Segundo o Sr. Oliveira, a comunidade lutou muito para que a rodovia fosse desviada 200 metros da FLONA, evitando que cortasse a mata, mas não obteve qualquer resposta do Poder Público. Ele também alertou para a falta de participação popular na tomada dessa decisão: "Nem audiência nos deram, porque nós, da associação, somos pobres. 0 Arco Metropolitano já está feito, não tem mais saída" (Oliveira in AGÊNCIA BRASIL, 2012).

Ciente desse cenário, no início de outubro de 2012, o Ministério Público Federal (MPF) convocou uma audiência pública por meio da Procuradoria Regional dos Direitos do Cidadão (PRDC/RJ ${ }^{77}$ ) para discutir os impactos ambientais da construção do Arco Metropolitano no Rio de Janeiro. 0 objetivo do evento foi "esclarecer os termos das licenças expedidas para a instalação do empreendimento, tendo em vista a presença de impactos

\footnotetext{
${ }^{77}$ Existem inquéritos civis relacionados às obras em andamento em mais de uma unidade do MPF no Rio de Janeiro. Na capital, o inquérito civil está sob a responsabilidade da procuradora da República Gisele Porto e, no interior, do procurador da República Renato Machado.
} 
irreversíveis sobre ecossistemas terrestres e aquáticos nos locais atingidos pelas obras da via" (ACSPR-RJ, 2012).

Na convocação dessa audiência, o MPF ainda colocou que estava apurando, inclusive através de inquéritos civis $^{78}$, os impactos das obras do Arco Metropolitano à Reserva Biológica Federal do Tinguá. Tais impactos são devido ao desmatamento de vegetação de Mata Atlântica no local, e à Floresta Nacional Mário Xavier e ao impacto das intervenções do empreendimento no habitat de espécies em extinção, como a rã Physalaemus Soaresi e o peixe Notholebias Minimus (ACSPR-RJ, 2012).

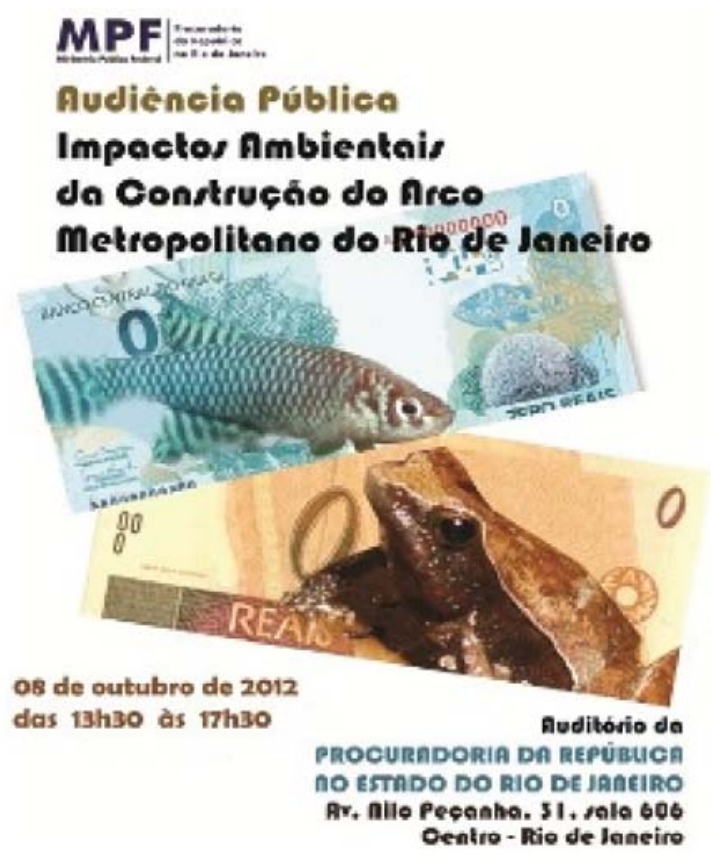

Figura 50 - Cartaz de divulgação da Audiência Pública "Impactos Ambientais da Construção do AMRJ”. Fonte: Site da Plataforma Dhesca Brasil, 2012.

\footnotetext{
${ }^{78}$ Entre as justificativas do MPF para convocar esta Audiência Pública estão os Inquéritos Civis $\mathrm{n}^{\circ}$ 1.30.017.000193/2007-18 e $n^{\circ} 1.30 .012 .000 S 41 / 2008-70$. 0 primeiro tramita na PRM São João de Meriti e apura os impactos do Arco Metropolitano à REBlO Tinguá, em função da supressão de vegetação de Mata Atlântica na sua zona de amortecimento. Já o segundo, apura a ocorrência de danos ambientais à Floresta Nacional Mário Xavier em razão da implementação do projeto denominado Arco Metropolitano do Rio de Janeiro. No Edital de chamada da audiência (ACSPR-RJ 2012), o MPF ainda cita a informação Técnica $n^{\circ}$ 003/2011RAN/ICMBI0,na qual é noticiado que "a execução da obra do Arco metropolitano causou fragmentação, destruição e alteração de habitats do último fragmento de área de vida disponível para a rã (Physalaemus Soaresi) e talvez o último para o peixe Notholebias Minimus, espécie de peixe anual também em perigo de extinção". O MPF menciona também o ofício DBGLO/IBAMA/NO 81/20J2, que noticia o fechamento, por prazo indeterminado, do Centro de Triagem de Animais Silvestres do IBAMA, situado na Floresta Nacional Mário Xavier, em razão das obras do Arco Metropolitano. No edital de chamada da audiência, o Ministério Público Federal lista ainda os estudos de inventário florestal para subsidiar a emissão das autorizações de supressão de vegetação e a realocação do CETAS (item 8.8 , Relatório Técnico $n^{\circ}$ 02/2012-PR/RJ/SEP), bem como a ocorrência de impactos irreversíveis sobre ecossistemas terrestres e aquáticos que sequer foram estudados, delimitados ou dimensionados no ElA.
} 
Segundo notícia do jornal O GLOBO (BOTTARI, 2012), a polêmica em torno dessas espécies, só foi superada quando o estado concordou em desembolsar doze milhões de reais para erguer a ponte sobre o pequeno lago no qual a rã foi localizada. Essa ponte, é, assim, uma tentativa de preservar o habitat natural da espécie.

Apenas em junho de 2013, quatro anos após as descobertas das espécies no trajeto do Arco, o 1CMBio publicou no Diário Oficial da União a portaria que aprova o Plano de Ação Nacional (PAN) para a conservação de animais ameaçados, sendo contempladas neste PAN cinquenta e três espécies de peixes (entre eles o Notholebias Minimus) e uma espécie de anfíbio (a Physalaemus Soaresi).

\subsubsection{Riscos pós-obra}

Como já mencionado, no seu texto de apresentação, o PDAM demonstra acreditar que a implantação de empreendimento de grande porte como o Arco Metropolitano possa ser feita de modo 'sustentável'. Contudo, ao longo do Plano, várias passagens deixam claro que, no passado, a criação de rodovias e de grandes empreendimentos industriais foram a razão de sérios problemas de degradação ambiental.

Ao apresentar o cenário atual da "área de estudo 2", o PDAM deixa transparecer, ainda que indiretamente, certa preocupação com os impactos da implementação do Arco na preservação ambiental da sua área de influência. 0 Plano cita a ação maléfica das estradas em área de interesse de preservação da biodiversidade. Isso se dá em trechos como no comentário que diz que "São grandes os esforços para a conservação da biodiversidade local [da região de influencia do Arco], já que esta região é atravessada por importante malha viária (BR 116, BR 101, RJ 097), induzindo a ocupação antrópica” (PDAM, 2011, p.71).

Como já comentamos no capítulo anterior, ao abordar essa ocupação antrópica lsidoro, Alcantara e Tângari (2011) colocam que a valorização do solo gera, entre outras consequências, a expulsão dos moradores originais. Nos seus estudos, essas autoras também elaboraram um cenário no qual a pressão da especulação imobiliária induz à expulsão das classes populares. Sem outra alternativa de moradia, essas classes acabam ocupando encostas ainda preservadas e outras áreas ambientalmente sensíveis ao longo da nova rodovia. 
Vários autores e comunicadores já expuseram os prejuízos socioambientais causados pelo AMRJ. Dentre os impactos a esse meio ambiente colocados por Montezuma (2013) e por Esteves (2013), estão também a poluição atmosférica, sonora e do solo, incluindo a sedimentação de corpos hídricos interceptados pelo Arco, e a expansão de áreas urbanas sobre áreas protegidas, incluindo a fragmentação de ecossistemas e perda ou alteração das funções ecológicas.

No que diz respeito à poluição dos corpos hídricos, já citamos aqui os problemas ambientais decorrentes do aumento de tráfego de navios e dos procedimentos de dragagem da Baía de Sepetiba. Além disso, sobre esses problemas, o Plano também alerta que a baía é abrigo de espécies de aves nativas, endêmicas e ameaçadas de extinção. Assim, o uso do Porto de ltaguaí por si só já é uma ameaça.

O PDAM também aborda a contaminação dos recursos hídricos devido à interferência do Arco. A rodovia cruza rios de relevância ambiental para preservação da biodiversidade e para o abastecimento de água para grande parte da população fluminense, como é o caso do Rio Guandu. 0 traçado do Arco Metropolitano também interfere em córregos e nascentes da bacia do Rio Guandu.

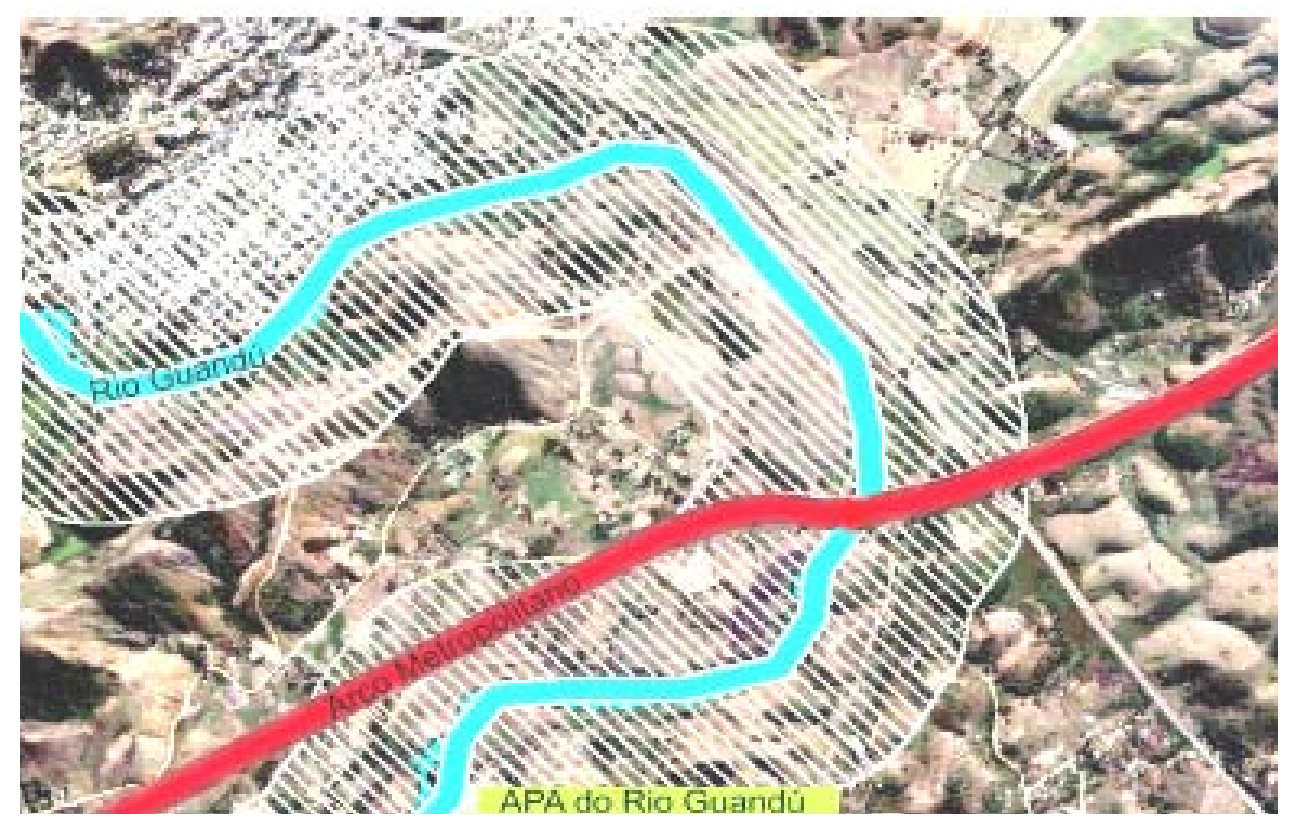

Figura 51 - Interferência do Arco no Rio Guandú e na sua faixa marginal de proteção. Fonte: PDAM, 2011, p.452.

Além da importância da proteção dos mananciais, o RIMA (2007) também menciona a possibilidade de derramamentos ao longo do AMRJ devido ao tráfego de caminhões com material perigoso. Caso ocorram derramamentos na via, estas substâncias perigosas 
provavelmente infiltrarão no solo, podendo chegar a interferir na qualidade das águas superficiais e subterrâneas do entorno do Arco.

No Plano é relatado um exemplo de impacto negativo decorrente de instalações industriais ocorrido na região delimitada como 'Área de Estudo $1^{79}$. Esta região é hoje indicada como um importante polo econômico para a Região Metropolitana do Rio de Janeiro, devido à presença do porto de Itaguaí e de empreendimentos siderúrgicos. Contudo, o PDAM (2011) lembra que,originalmente, esta área era coberta por Floresta Ombrófila Densa, manguezais, matas ciliares e comunidades aluviais que já não existem mais. Apesar da grande degradação dos antigos fragmentos florestais, o PDAM (2011) destaca que ainda existem, nesta região, áreas ambientalmente valiosas que resistem à essa forte pressão antrópica.

Ao falar da Bacia da Baía de Sepetiba, o Plano adverte que a alta concentração de indústrias nessa região pode agravar ainda mais esse quadro.Porém, algumas páginas depois, o PDAM ameniza a ação maléfica das indústrias e atribui aos esgotos domésticos boa parte da culpa pela poluição das baías de Sepetiba e da Guanabara. Desta forma, levanta a hipótese de que "a poluição orgânica de origem industrial é de menor relevância frente aos níveis de poluição de origem doméstica verificados na bacia, em face do bom desempenho ambiental das principais indústrias com potencial de geração desse tipo de carga” (PDAM, 2011, p.95).

O Plano vai assim, ao longo do seu texto, relativizando quem seria o maior setor poluidor. O documento cita que tanto as indústrias como as 'ocupações irregulares' prejudicam o meio ambiente, mas não fornece dados comparativos claros sobre a contribuição de um e de outro. Ao apresentar a cena atual das Águas Subterrâneas na região da Bacia da Baía de Sepetiba, por exemplo, o PDAM (2011) adverte que os processos irregulares de ocupação das margens dos canais de drenagem são a causa de grande parte do problema atual. Tais ocupações ocorrem, quer seja por favelas ou por instalações comerciais, como por postos de gasolina, pequenas fábricas e oficinas.

O RIMA (2007) também alerta para a questão das indústrias e das 'ocupações irregulares' como antropismo que afeta diretamente o meio ambiente. No item "pontos críticos de cruzamentos da rodovia” o RIMA cita as áreas do Arco nas quais deverão ocorrer

\footnotetext{
${ }^{79}$ Constituída pelos municípios de Itaguaí, Seropédica, Mangaratiba e pelas subáreas de planejamento 5.3 e 5.2, da Área de Planejamento 5, AP-5, do município do Rio de Janeiro (PDAM, 2011, p.6).
} 
maior pressão de ocupação e tendências de crescimento. Neste item, enfatiza a necessidade de cuidados especiais quanto ao ordenamento do uso e ocupação desses espaços.

Tanto o PDAM (2011) como o RIMA (2007) citam as principais Unidades de Conservação (UCs) que estão na área de abrangência do AMRJ. 0 Plano se refere a todas as UCs de forma homogênea, enquanto o Relatório dá destaque para as unidades adjacentes ou cortadas pelo Arco, tendo como fundamentação a Resolução CONAMA n 13/90. Essa resolução condiciona a instalação de qualquer atividade próxima a uma Unidade de Conservação (em um raio de $10 \mathrm{~km}$ ) à autorização do órgão responsável pela administração da respectiva unidade. Assim, levando em consideração tal resolução, para a construção do Arco foi necessária a autorização dos responsáveis das UCs listadas a seguir.

\begin{tabular}{|c|c|c|c|}
\hline Nome & Tipo & Administração & Distância (m) \\
\hline FLONA/Mario Xavier & Uso Sustentável & Federal & 0 \\
\hline APA Rio D'ouro & Uso Sustentável & Municipal & 0 \\
\hline APA Retiro & Uso Sustentável & Municipal & 0 \\
\hline APA Guandu & Uso Sustentável & Estadual & 0 \\
\hline APA do Tinguá & Uso Sustentável & Municipal & 10 \\
\hline REBIO Tinguá & Proteção Integral & Federal & 1.300 \\
\hline APA Morro Agudo & Uso Sustentável & Municipal & 1.800 \\
\hline APA Jaceruba & Uso Sustentável & Municipal & 2000 \\
\hline APA Gericinó - Mendanha & Uso Sustentável & Estadual & 9.500 \\
\hline
\end{tabular}

Figura 52 - Unidades de Conservação listadas por proximidade ao AMRJ. Fonte: (RIMA, 2007, p.29).

O Plano coloca uma grande apreensão com os processos de urbanização ao longo do Arco, temendo que o crescimento demográfico e a agricultura tragam malefícios para as áreas ambientais por conta de grandes desmatamentos. No entanto, vê como positiva a "nova dinâmica de desenvolvimento regional” dada pela criação de zonas industriais em determinados trechos da rodovia, sobretudo nas proximidades de centros industriais como Duque de Caxias. 0 documento ainda levanta a necessidade do reordenamento territorial, tendo em vista a instalação de uma nova dinâmica socioeconômica com a chegada do Arco.

Tanto o Plano quanto o Relatório alertam, por diversas vezes, para a importância da conservação ambiental, citando, por exemplo, a relevância da continuidade das áreas preservadas, com a criação de corredores ecológicos e evitando a formação de "ilhas de vegetação".

Contraditoriamente, em um trecho do município de Seropédica, o Arco corta, quase que ao meio, a Floresta Nacional Mário Xavier, causando assim diversos problemas na fauna local, como acabamos de ver. Em um dos mapas do Estudo de Impacto Ambiental (2007) 
fica claro que outras opções foram cogitadas, inclusive uma variante em que o traçado do Arco quase não afetaria a FLONA Mário Xavier, conforme a figura 53.

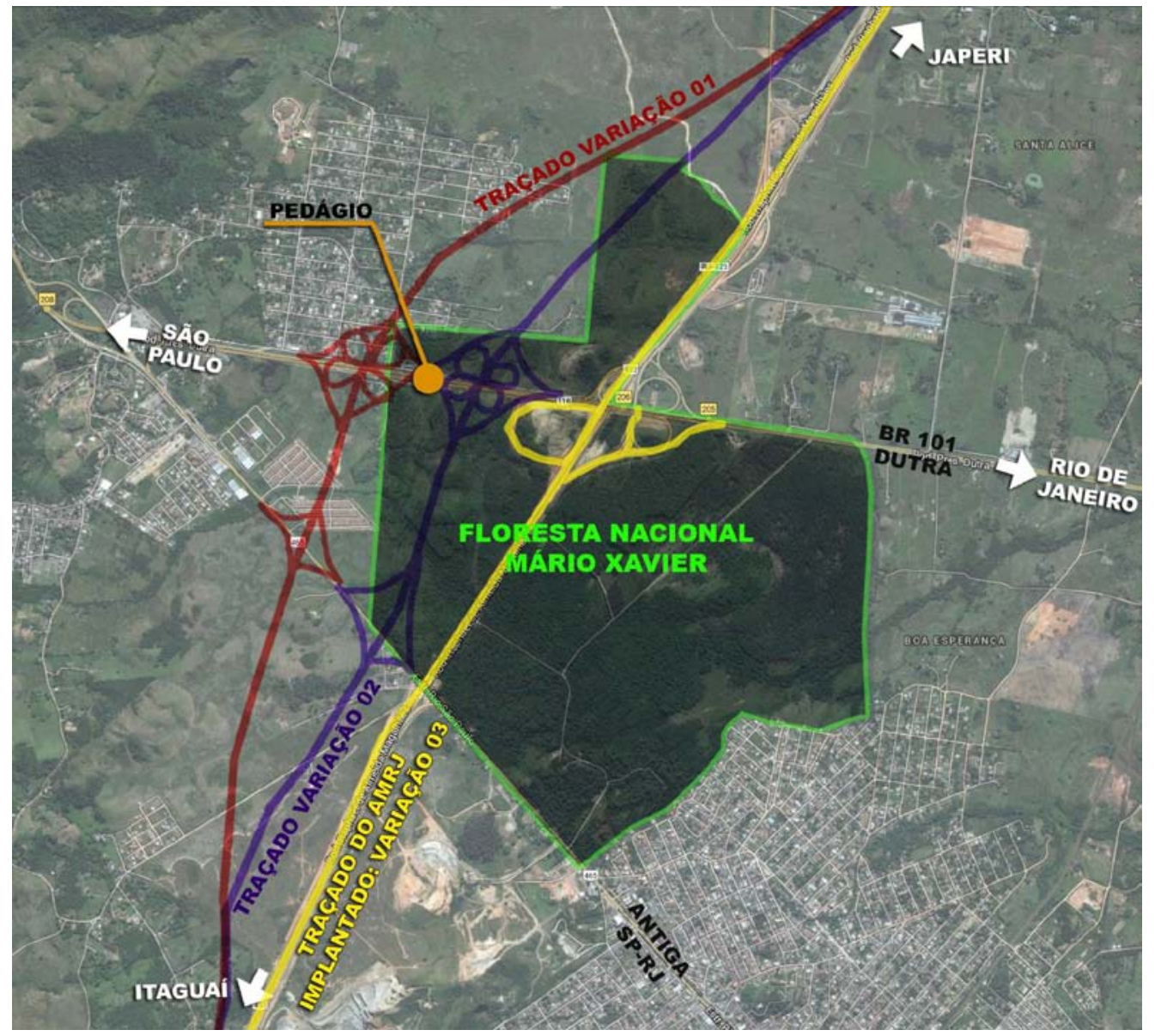

Figura 53 - Opções de traçado do Arco sobre FLONA Mário Xavier. Fonte: Elaboração própria com base no RIMA (2007) e no Google Earth.

Sobre esta floresta, cabe ainda destacar que o RIMA (2007) apresenta uma série de mapas com os remanescentes de Mata Atlântica que integram o Corredor de Biodiversidade da Serra do Mar em cada município da área de influência indireta do Arco Metropolitano. Curiosamente, nestes mapas a FLONA Mário Xavier não aparece pintada com a cor verde, que indica os locais onde há vegetação de Mata atlântica.

Alguns autores lembram que na época do licenciamento foi usado o fato de parte da FLONA Mário Xavier ser ocupada por plantação de eucalipto. Isso pode explicar o erro do RIMA. Contudo, em visita ao local, pudemos constatar que o eucalipto está restrito a apenas uma parcela da floresta e grande parte dela ainda tem Mata Atlântica.

Além disso, a floresta é classificada como tendo Bioma Mata Atlântica segundo os dados do Instituto Chico Mendes de Conservação da Biodiversidade (ICMBio). Assim, tal erro é tecnicamente pouco justificável. Portanto, pode-se levantar a hipótese de que essa visão 
da floresta como uma plantação de eucalipto pode ter sido intencional para minimizar a repercussão dos impactos ambientais dentro da Floresta.

Alguns especialistas atacam essa postura afirmando que "a FLONA não é uma reserva de eucaliptos. Até agora o 1CMBio foi negligente com ela e com as espécies que lá vivem. A rã e outros animais passaram batidos (foram esquecidos) nos estudos ambientais” (PEREIRA in BOURSCHEIT, 2009b). Potsch (in MENDONÇA, 2009) também lembra que ainda que se argumente que a mata em si não tem grande importância científica, aquela mata tem um relevante significado como habitat de inúmeras espécies ameaçadas de extinção.

O RIMA (2007)afirma que esta opção de traçado é decorrente da hipótese de que o menor impacto seria causado se o Arco Metropolitano, (via cuja seção transversal descrita no próprio RIMA (2007) varia de cinquenta a cem metros) seguisse, nesse trecho, o caminho de uma antiga estrada estadual (a RJ-105), desativada há muitos anos. Em uma simples visita de campo, foi possível notar que a referida RJ-105 estava longe de ter dimensões compatíveis com a implantação do Arco, possuindo no máximo, quatro metros de seção. Pela descrição dos funcionários da FLONA Mário Xavier, antes do início das obras do Arco, este caminho se assemelhava mais com uma trilha comum no meio da floresta do que com uma antiga estrada, não justificando assim, tal intervenção.

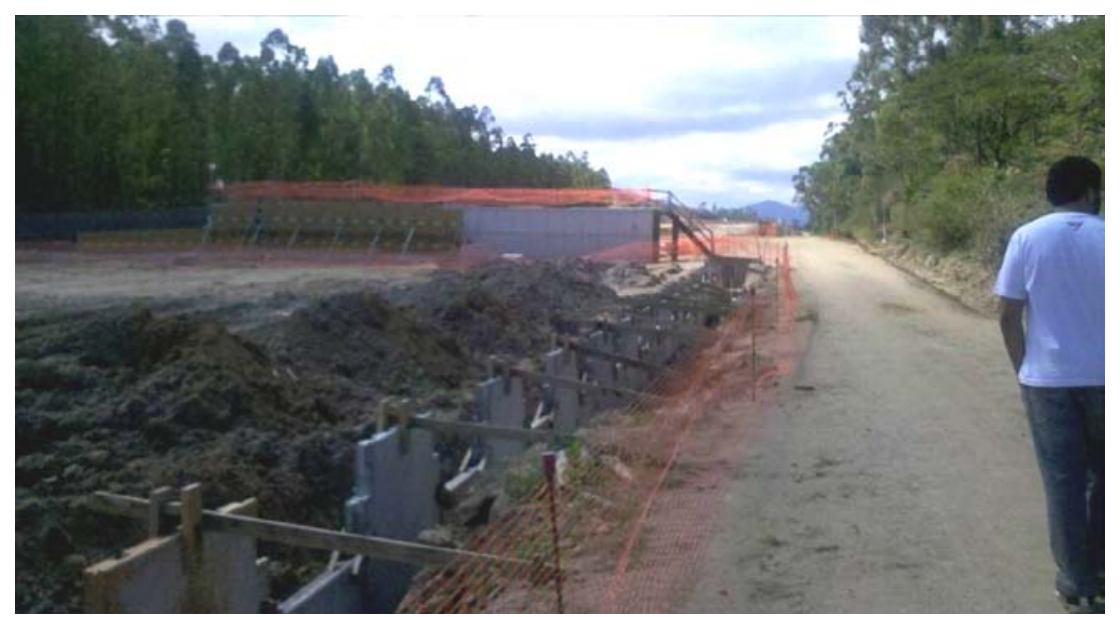

Figura 54 - A trilha que abriga a maior rodovia do estado Foto. À direita da foto, o caminho da antiga "estrada" estadual (RJ-105). À esquerda da foto, a obra do AMRJ e todo o espaço por ela desmatado. Fonte: acervo de Ticianne Ribeiro de Souza, 2013.

Além da alteração do traçado a pesquisadora Simone Freitas (2012) também aponta que a rodovia poderia ter sido construída em ponte no trecho que passa pela Floresta, como ocorre, por exemplo, na rodovia imigrantes (SP-160). Segundo Freitas (2012) a passagem das espécies pelos dois lados da floresta é fundamental para a sobrevivência da espécie pela maior possibilidade de reprodução. Ela explica, que os bichodutos sob rodovias, em geral, 
não são locais atrativos para os animais, pois são barulhentos, não se assemelham com uma floresta e ainda os deixa demasiado expostos a predadores. Assim, ainda que a ponte também cause danos ambientais durante as obras, ela permite a recomposição da floresta no pós obra, viabilizando a livre passagem dos animais.

Com esse exemplo, reiteramos que não estamos aqui questionando a necessidade e a utilidade da construção do Arco. Estamos apenas questionando o modo como a rodovia foi construída. Se havia soluções técnicas que viabilizavam a construção de uma rodovia e também preservavam a biodiversidade, porque elas não foram executadas?

Sobre a escolha entre as alternativas de traçado, uma das respostas que se aventou e que apareceu nas entrevistas, embora não possamos comprová-la, foi que a alternativa executada foi eleita por conta da maximização da cobrança de pedágio. Segundo relato de Andrea Ribeiro (informação pessoal ${ }^{80}$ ), ex-coordenadora da FLONA Mário Xavier, a escolha do traçado seguiu a necessidade de se construir o Arco a leste do pedágio existente na Dutra (BR-116). Assim, todos os veículos do percurso RMSP - RMRJ continuarão tendo que pagar esse pedágio, cujo valor cobrado pela concessionária "CCR Nova Dutra" é superior a dez reais desde junho de 2012. De acordo com Andrea Ribeiro (informação pessoal), apesar da segunda opção de traçado também se localizar a leste do pedágio, ela foi descartada por não ter distância mínima suficiente entre o pedágio e as alças de ligação do AMRJ que viabilizasse a manutenção do pedágio existente no local atual.

Segundo Riley Rodrigues, especialista da FIRJAN ${ }^{81}$ (informação pessoal, 2014) essa alternativa de passar por dento da FLONA se deu por conta do custo com desapropriações. Como a floresta é uma área pública, passar pela floresta (conforme traçado variação 3 da figura 53) significou uma economia com desapropriação. Vale lembrar que o trecho "C" do Arco tem cerca de 74 quilômetros e teve inúmeras áreas desapropriadas. A passagem do Arco por fora do FLONA (conforme traçado variação 1 da figura 53) acarreta em apenas cerca de cinco quilômetros a mais de desapropriação do que a variação 3 implantada.

Quanto à possibilidade de passagem em ponto, Andrea Ribeiro (informação pessoal, 2014) e Riley Rodrigues (informação pessoal, 2014) apontam que essa opção teria sido descartada devido ao custo da construção de uma ponte ser superior ao custo dos

\footnotetext{
${ }^{80}$ Entrevista concedida no dia 16 de Maio de 2014, na sede da Floresta Mario Xavier, Seropédica - RJ. Gravada em áudio, formato MPEG-4.

${ }^{81}$ Especialista do Sênior em Competitividade Industrial e Investimentos da Federação das Indústrias do estado do Rio de Janeiro.
} 
"bichodutos". Novamente, ressaltamos que o trecho todo que corta a Floresta Nacional Mario Xavier possui menos de dois quilômetros.

Percebemos assim, que os prejuizos ambientais na FLONA não se deram pela necessidade de se construir a rodovia mas sim, por uma economia de custos em uma obra orçada inicialmente em menos de oitocentos milhões e que foi finalizada por 1,9bilhões, ou seja, mais do que o dobro do valor estimado.

Além dessa escolha por corte de custos ter se dado justo nas questões de impactos ambientais,vale ressaltar que a Floresta é uma área pública justamente para viabilizar a sua preservação. Esta área não faz parte de um banco de terras públicas disponíveis para qualquer fim, uma FLONA não é um terreno como um outro qualquer. A Floresta Mario Xavier é uma área demarcada deste de 1984 como "Floresta Nacional".

"Floresta Nacional" é uma categoria definida pelo Sistema Nacional de Unidades de Conservação da Natureza (SNUC) ${ }^{82}$ que designa áreas de posse e domínio públicos, cuja visitação é permitida, mas é condicionada às normas estabelecidas para o manejo da unidade. A lei do SNUC ainda coloca que atividades de pesquisas ambientais nessas áreas são permitidas e devem ser incentivadas. Na criação de uma FLONA, caso o governo federal não seja proprietário de toda a área, os terrenos particulares incluídos na delimitação da floresta devem ser desapropriadas, para que o Estado seja o único proprietário.

Assim, o Estado é dono da FLONA Mário Xavier exatamente para que preservação dela seja garantida. 0 fato do próprio governo utilizar essa prerrogativa de posse, para infringir a preservação da área, pode ser considerado uma improbidade administrativa e faz com que se levante acusações de que o Estado estaria cometendo um crime ambiental, conforme aqui já colocado por Haddad (in BOURSCHEIT, 2009).

Um ano antes da conclusão do relatório final do Plano do Arco, Marciano et al. (2010) já indicavam as várias Áreas de Proteção Ambiental que seriam afetadas pelo AMRJ e demonstravam uma expectativa de que o PDAM tratasse dessas questões.Ainda que tivessem expectativas quanto ao PDAM, Marciano et al. (2010) advertiram que as autoridades não haviam debatido sobre a perda de biodiversidade na FLONA Mário Xavier. Os autores demonstravam assim, que as questões de cunho ambiental estavam sendo menosprezadas, não sendo amplamente divulgadas e recebendo tratamento secundário.

O RIMA (2007) parece justificar o Arco como um mal necessário. Em suas propostas de medida ambiental aparecem constantemente as palavras "evitar" e "desnecessários".

\footnotetext{
${ }^{82}$ Conforme lei No 9.985 , de 18 de julho de 2000.
} 
Assim, o relatório propõe, entre outros: evitar desmatamentos desnecessários; evitar a implantação de canteiros de obras próximos a ambientes florestados quando desnecessário; e evitar a formação de focos erosivos nas margens dos rios.

Cardoso e Araújo (2012) também constataram que os discursos presentes em outros documentos oficiais indicam uma preocupação com as questões ambientais, mas não são taxativos. Desta forma, o projeto consegue mitigar as críticas feitas a ele e, ao mesmo tempo, permitir que as decisões variem de acordo com os interesses financeiros que giram em torno do empreendimento. Conforme já falamos no primeiro capítulo, tem-se assim, uma abertura para a aplicação arbitrária dos documentos oficiais. De acordo com Maricato (2002), essa arbitrariedade tende a favorecer aos grupos dominantes da sociedade.

Neste mesmo viés, discursos e ações de instituições responsáveis pela preservação do meio ambiente como o IBAMA, ou mesmo o Instituto Chico Mendes de Conservação da Biodiversidade (ICMBio) também se aproximam da postura refletida no EIA-RIMA, o qual afirma que "a fauna silvestre pode sofrer impactos diversos devido ao ruído e poluição, tais como emigração, inibição da natalidade etc.", porém não se mostra taxativo neste aspecto, tampouco indica soluções de alteração no traçado para fora da FLONA, pois isto representaria um aumento considerável nos custos financeiros do empreendimento. No cerne desta conjuntura, nebulosa e mascarada, pode-se pensar que a euforia desenvolvimentista à qual foi associado o projeto do Arco conseguiu sucesso retórico ao criar consensos sobre a necessidade e a inevitabilidade do projeto, inviabilizando quaisquer objeções referentes aos impactos ambientais e sociais dessa intervenção (CARDOSO E ARAÚJO, 2012, p. 108 e 109).

Os autores ainda consideram que as ameaças ambientais não se dão apenas na Floresta Nacional Mário Xavier, apesar desta área de proteção ambiental ter tido mais destaque na mídia. Conforme listado no primeiro parágrafo deste tópico, outras importantes APAs sofrerão impactos do Arco, como por exemplo, as APAs do Retiro, Tinguá e rio D’Ouro (ver figura 56).

Com base no modelo de simulação de crescimento urbano Clarke Urban Grow Model (SLEUTH), o PDAM constata que, entre 2007 e 2030, as áreas florestais não irão diminuir. Segundo o Plano, essas áreas aumentarão pouco significativamente conforme mostra o gráfico abaixo. No mesmo gráfico nota-se que os usos urbanos aumentarão em mais de 50\%, enquanto os outros usos diminuirão. 


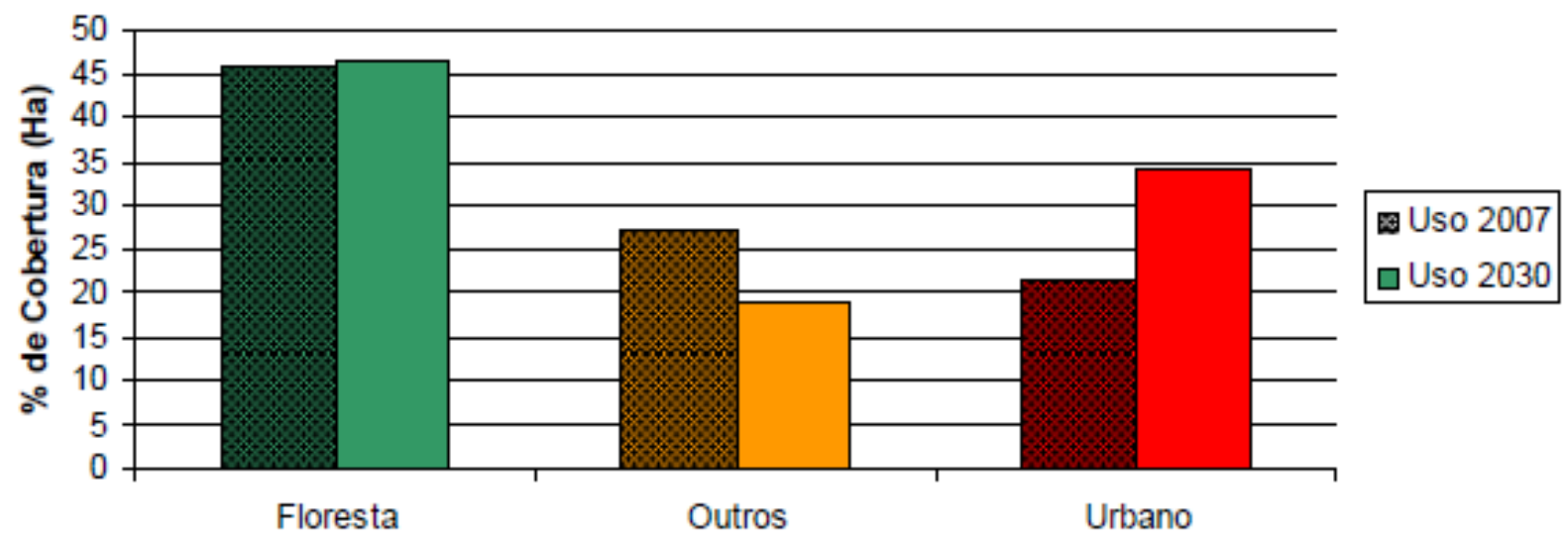

Figura 55 - Dinâmica de Uso de Solo. Fonte: PDAM, 2011, p.435.

Contudo, ao apresentar os prováveis cenários futuros, o Plano se contradiz expondo uma perspectiva diferente. Sendo mais realista, o documento prevê enormes pressões sobre as áreas de preservação ambiental. A facilitação do acesso às Unidades de Conservação e a implantação de determinadas atividades nas suas zonas de amortecimento são indicadas como grande ameaça à preservação das UCs.

Cabe lembrar que implantação da rodovia em si é também um causador de inúmeros desmatamentos. A própria tipologia desta rodovia (ver figura 7 do capítulo 2) também é indutora de urbanização acelerada, vez que prevê vias laterais que permitem o fácil acesso às ocupação em áreas lindeiras ao Arco.

Ademais, a recomendação de estímulo à industrialização em áreas ao longo do Arco (como vimos anteriormente) também representa uma grande ameaça à preservação ambiental, visto que existem terrenos vagos ao longo do Arco próximo às UCs. Além de passar por dento da FLONA Mário Xavier, como já vimos, o AMRJ também corta a Área de proteção ambiental (APA) da Pedra Lisa, a APA do Rio D'ouro e passa ao lado da APA Tinguazinho (ver figura 56). 


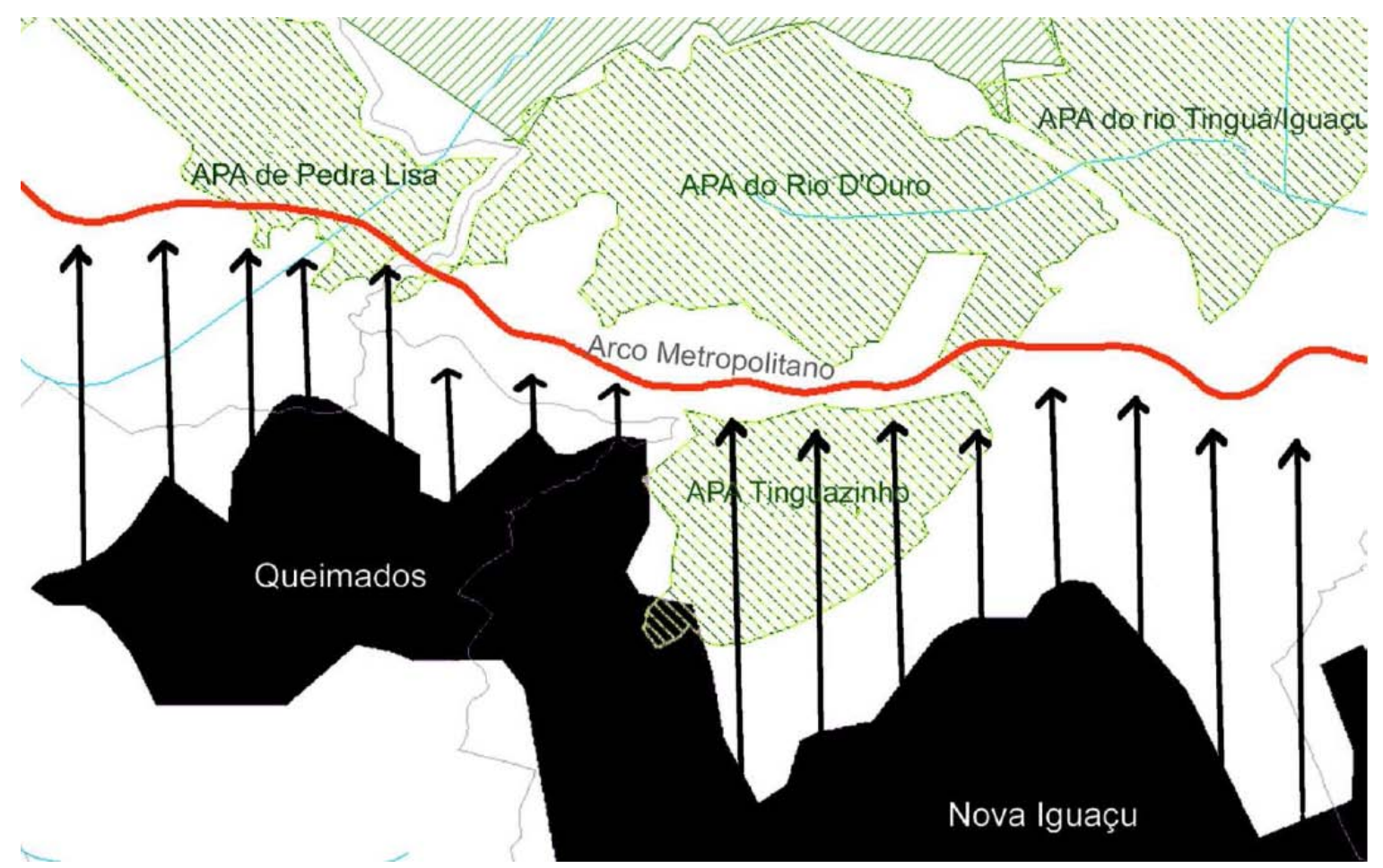

Figura 56 - Pressão sobre as Unidades de Conservação (terrenos vagos em branco, mancha urbana em preto, Arco em vermelho e UCs em verde. Fonte: PDAM, 2011, p. 450.

Pela análise de imagens do Google Street View (2015) podemos notar que no trecho em que o Arco passa entre a APA Tinguazinho e a APA do Rio D'Ouro, a rodovia não apresenta barreiras que inibam satisfatoriamente à ocupação das áreas adjacentes a estas APAs (figura 57). Pelas imagens datadas de dezembro de 2014, notamos que já há, inclusive, acessos informais do Arco á vias previamente existentes (figura 58).

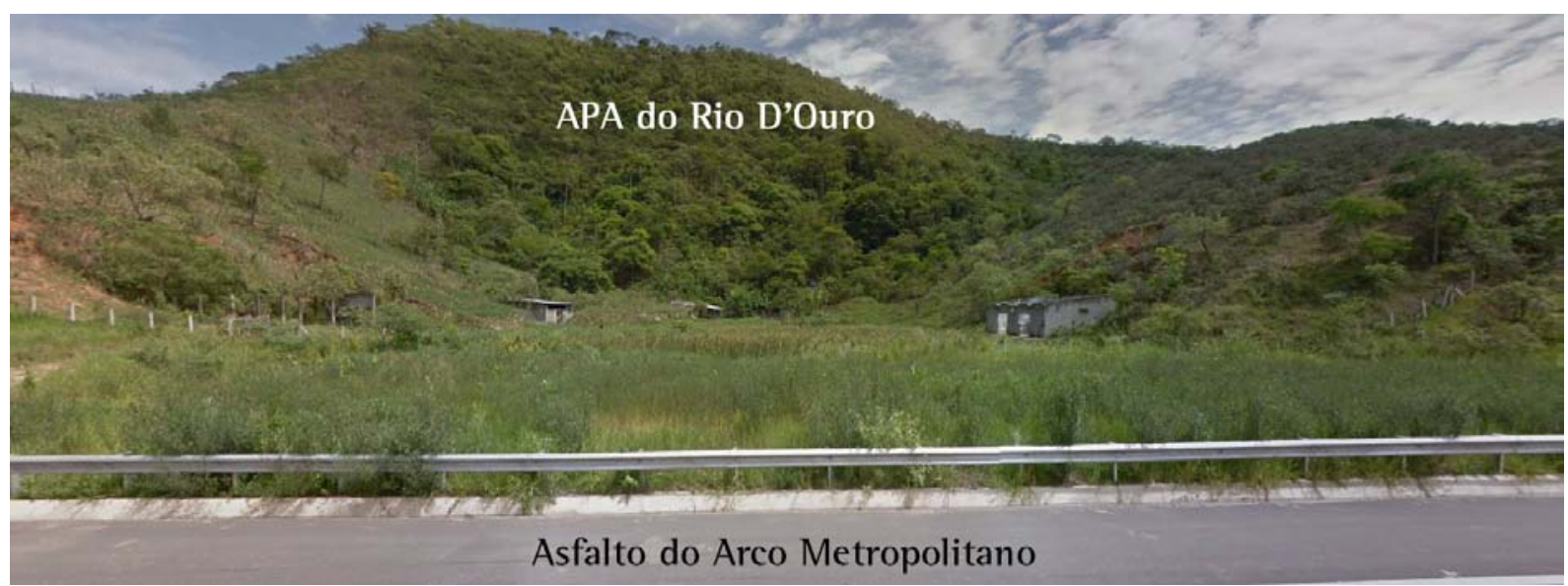

Figura 57 - Divisão entre a rodovia e a APA do Rio D’Ouro, com edificações em locais planos. Fonte: Elaboração própria com base em imagens do Google Street View, 2015. 


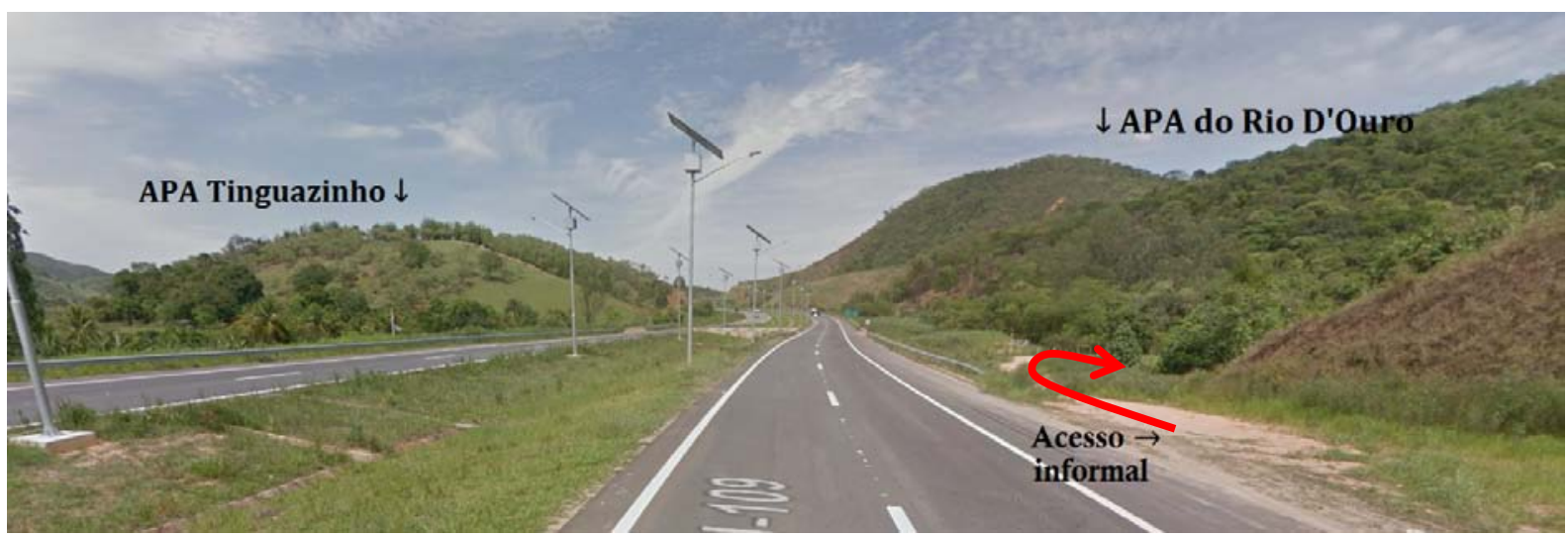

Figura 58 - Passagem entre a APA Tinguazinho e a APA do Rio D’Ouro. Fonte: Elaboração própria com base em imagens do Google Street View, 2015.

Conforme mostra a imagem a seguir (figura 59), no trecho em que o Arco passa por dentro da APA da Pedra Lisa não há qualquer tipo sinalização muito menos barreiras físicas. Em um determinado momento não há nem meio fio entre o asfalto da rodovia e a vegetação da área de proteção.

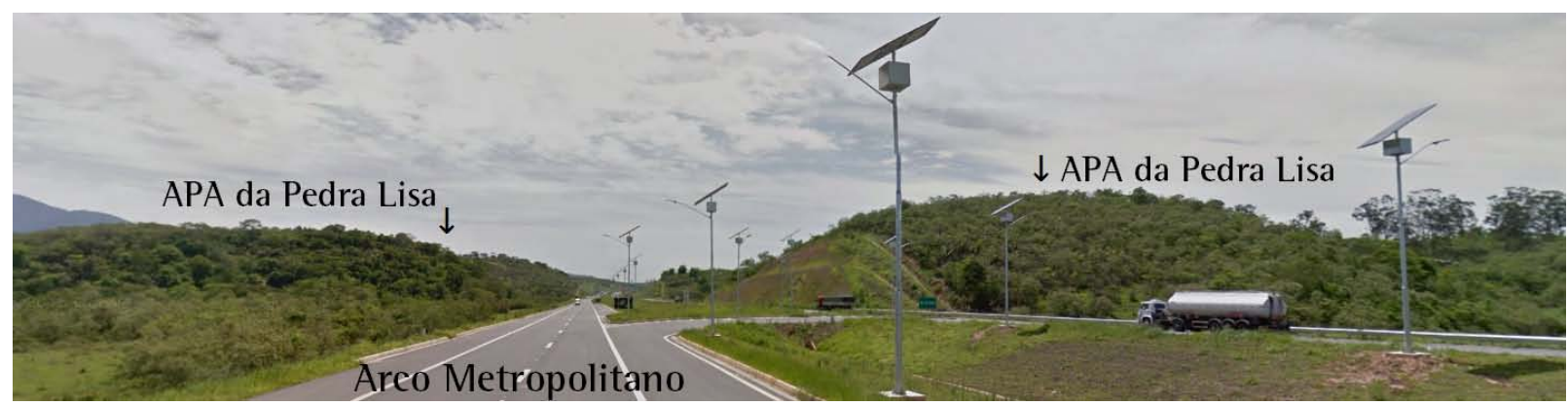

Figura 59 - Inexistência de barreiras entre o Arco Metropolitano e a APA da Pedra Lisa. Fonte: Elaboração própria com base em imagens do Google Street View, 2015.

Com relação à compensação ambiental do Arco, boa parte do plantio previsto se dará no Parque Estadual da Pedra Branca (PEPB). Este parque é visto como uma "joia ambiental", localizada na zona oeste carioca, mas possui problemas "decorrentes do abandono pelo poder público e da ocupação irregular, que só aumenta desde sua criação, em 1974" (THUSWOHL, 2011). Apesar destes problemas, há uma tentativa de transformação do parque em atração de turismo ecológico. Por isso, fazem parte dos planos do governo estadual a alteração dos atuais limites e criação de um "Parque do Carbono".

0 plantio das mudas no "Parque do Carbono" se daria em decorrência de processos de compensação ambiental de empreendimentos privados e públicos como, por exemplo, o Arco Metropolitano. A princípio, o projeto prevê que sejam utilizadas mudas de cinquenta espécies nativas. Em 2011 foi noticiado o inicio da primeira fase de plantio em uma área de 
204 hectares,com verbas da Petrobras, como compensação pelas emissões do campo Lula de Pré-Sal (MOTTA, 2011). De acordo com o diretor de Biodiversidade e Áreas Protegidas do Instituto Estadual de Ambiente (INEA), André llha (in THUSWOHL, 2011), outras empresas também poderão compensar suas emissões de gases poluentes ali. Ele explicou que, à medida que crescem, as mudas sequestram o carbono da atmosfera e, consequentemente, reduzem os gases de efeito estufa.

Em 2015, entramos em contato com o Coordenador do PEPB, Alexandre Marau Pedroso, que informou que o plantio das mudas referentes à compensação ambiental do Arco Metropolitano ainda não foi executado. Segundo Alexandre, eles já disponibilizaram o arquivo georreferenciado com a demarcação de uma área de 180 hectares, para o setor de licenciamento do INEA escolher, juntamente com o Gerente de Reflorestamento da Secretaria Municipal de Meio Ambiente do Rio de Janeiro, Marcelo Hudson, uma área de 40 hectares para o plantio dessas mudas.

Cardoso e Araujo (2012) fazem uma crítica à postura governamental perante as compensações ambientais. Eles consideram que o ElA-RIMA do Arco tende a admitir os impactos ambientais sem cogitar a hipótese de reduzi-los ou evitá-los, apenas indicando que eles deverão ser compensados.

No item "Gestão de Áreas Protegidas e Conservação da Biodiversidade", em único parágrafo, o Plano expõe o fato do traçado da rodovia cortar uma Unidade de Conservação e, ao mesmo tempo, trata de "garantia de proteção de recursos naturais" e "proteção da Biodiversidade”, não reconhecendo que a existência da própria rodovia no meio de Unidades de Conservação já é, por si só, fator suficiente para colocar em risco esses dois itens.

Quanto às proposições, o PDAM (2011) aponta como diretriz ambiental a revisão dos Planos de Manejo/Gestão das UCs da região de influência, priorizando aquelas que forem cortadas pelo Arco ou que estejam mais próximas da rodovia. O Plano também prevê que os recursos da Compensação Ambiental do Arco e de outros empreendimentos que venham a se instalar na região sejam utilizados para: regulamentação fundiária; instrumentalização da gestão e manutenção das Unidades de Conservação; programas de recuperação de APPs (com ênfase nas matas ciliares) de áreas degradadas; e revegetação de áreas para promoção de corredores ecológicos (PDAM, 2011). Além disso, aponta como diretrizes ambientais o fortalecimento do Corredor da Biodiversidade e a recuperação de Áreas Degradadas e de Áreas de Preservação Permanente. 
Contudo, após essas recomendações, de forma extremamente contraditória, o Plano recomenda o Desenvolvimento de Atividades Econômicas Sustentáveis (de baixo impacto ambiental) no entorno das Unidades de Conservação e das zonas de amortecimento. Como apontamos anteriormente, o Arco em si é uma obra de cunho econômico, de alto potencial poluidor, que estimula um modal menos sustentável de transporte e que passa por dentro de uma unidade de conservação (UC) e nas zonas de amortecimento de outras tantas.

Além disso, cabe lembrar que o Arco é uma rodovia que tem o intuito de estimular a instalação de novas industrias na baixada fluminense e proporcionar facilidades logísticas aos "empreendimentos alicerces" e aos "empreendimentos aderentes". Conforme informações constantes no próprio PDAM (2011) todos esses empreendimentos possuem alto potencial poluidor.

Logo nas suas primeiras páginas, em um exemplo claro do uso ideológico do mito desenvolvimentista, como visto no capitulo 1, o PDAM afirma que o Rio de Janeiro participa do atual modelo de desenvolvimento do país, "com programas de vigoroso recrudescimento econômico, ao mesmo tempo em que fortalece sua conduta ambiental, cuidando de seus recursos naturais na perspectiva de processos sustentáveis” (PDAM, 2011, p.3).

Contudo, como vimos aqui, o termo "sustentabilidade" pode ser empregado de diversas formas. Como já colocado por Harvey (2014), o capitalismo se apropria desse termo, utilizando-o de forma superficial e comercial. Cabe lembrar que, para diversos autores, a "sustentabilidade”, na sua essência de preservação da natureza, é incompatível em concomitância como sistema de produção e consumo capitalista atual (FERRElRA; FERRARA, 2012) (BERTUCCl et al. 2002). Assim, uma argumentação não falaciosa sobre a "sustentabilidade" passa necessariamente pela discussão da mudança no padrão de consumo e da busca de meios alternativos menos destrutivos para sobreviver harmonicamente no planeta (FERREIRA; FERRARA, 2012).

Ao mesmo tempo em que propõe o “desenvolvimento sustentável”, o Arco Metropolitano faz parte de uma série de investimentos bilionários para a instalação de uma complexa rede de empreendimentos no setor industrial. Conforme indicado na figura 60, todos esses empreendimentos, sem nenhuma exceção, foram classificados pela FEEMA ${ }^{83}$ (2007) como sendo de alto potencial poluidor.

\footnotetext{
${ }^{83}$ Fundação Estadual de Engenharia do Meio Ambiente (FEEMA), fundida em 2009 à Superintendência Estadual de Rios e Lagoas (SERLA) e ao Instituto Estadual de Florestas (IEF) com a criação do Instituto Estadual do Ambiente (INEA).
} 


\begin{tabular}{|c|c|c|c|c|}
\hline EMPREENDIMENTO & MUNICÍPIO & $\begin{array}{l}\text { ÁREA DE } \\
\text { ESTUDO }\end{array}$ & SETOR & $\begin{array}{l}\text { POTENCIAL } \\
\text { POLUIDOR * }\end{array}$ \\
\hline Arco Metropolitano & $\begin{array}{l}\text { Itaboraí, Guapimirim, } \\
\text { Magé, Duque de } \\
\text { Caxias, Nova Iguaçu, } \\
\text { Japeri, Seropédica e } \\
\text { Itaguaí }\end{array}$ & I, II, III & $\begin{array}{l}\text { Transportes } \\
\text { Logistica }\end{array}$ & Alto (construção) \\
\hline $\begin{array}{c}\text { Plataforma Logística CSN } \\
\text { - } \quad \text { Expansão TECON } \\
\text { - } \text { Expansão TECAR } \\
\text { - Pólo Logístico } \\
\text { Porto Privativo Lago da } \\
\text { Pedra }\end{array}$ & Itaguaí & \multirow{9}{*}{ I } & \multirow[t]{6}{*}{$\begin{array}{l}\text { Transportes } \\
\text { Logística }\end{array}$} & Alto \\
\hline Porto Sudeste LLX & Itaguaí & & & Alto \\
\hline Porto Petrobrás & Itaguaí & & & Alto \\
\hline Porto Usiminas & Itaguaí & & & Alto \\
\hline Porto Gerdau & Itaguaí & & & Alto \\
\hline Porto Itaguaí - CDRJ & Itaguaí & & & Alto \\
\hline $\begin{array}{ll}\text { CSA Usina Siderúrgica } \\
\text { - Porto CSA }\end{array}$ & Rio de Janeiro & & $\begin{array}{l}\text { Siderurgia } \\
\text { Transportes } \\
\text { Logistica }\end{array}$ & Alto \\
\hline $\begin{array}{l}\text { CSN } \\
\text { - Usina Siderúrgica } 2\end{array}$ & Itaguaí & & Siderurgia & Alto \\
\hline Coquepar & Seropédica & & Petroquímica & Alto \\
\hline REDUC - Ampliação Refinaria & Duque de Caxias & \multirow[b]{3}{*}{ II } & Petroquímica & Alto \\
\hline Bayer - Expansão & Belfort Roxo & & Química & Alto \\
\hline Estaleiro EISA & Rio de Janeiro & & Indústria Naval & Alto \\
\hline COMPERJ & Itaboraí / São Gonçalo & \multirow{4}{*}{ III } & Petroquímica & Alto \\
\hline STX Europe & Niterói & & \multirow[t]{3}{*}{ Indústria Naval } & Alto \\
\hline Estaleiro Mauá & Niterói & & & Alto \\
\hline Estaleiro Aliança & Niterói & & & Alto \\
\hline
\end{tabular}

Figura 60 - Potencial poluidor dos empreendimentos alicerces e dos empreendimentosaderentes. Fonte: FEEMA, 2007. MN-050.R-2 - Classificação de Atividades Poluidoras. (PDAM, 2011, p. 455)

Assim, nas áreas do COMPERJ e da Província Portuária de Sepetiba são esperadas alterações da qualidade do ar devido às novas emissões atmosféricas previstas. Tais emissões podem levar a "concentrações máximas de ozônio ainda maiores que as atualmente apuradas" no local (PDAM, 2011, p. 451). 0 mesmo pode ocorrer em todo o eixo do Arco por conta do aumento do tráfego de veículos em áreas hoje não urbanizadas.

Além dos impactos ambientais decorrentes do aumento do tráfego de navios e dos serviços de dragagem, o PDAM reconhece que o Programa de Despoluição da Baía de Guanabara $(\mathrm{PDBG})^{84}$ não conseguiu os resultados esperados. Agravando esse cenário, é necessário lembrar que, com base em dados da FEEMA (2007), as indústrias alimentícias e químicas (especialmente as petroquímicas) são as principais responsáveis pelo lançamento de carga poluente na Baía da Guanabara, sobretudo no que diz respeito aos metais pesados. Assim, fica claro que todos os ditos "empreendimentos alicerces" e os "empreendimentos aderentes" representam um enorme risco ao meio ambiente.

Ao citar o complexo logístico-industrial no qual o Arco se insere, o PDAM segue com essa lógica de desenvolvimento sustentável apoiando-se no compromisso que diversos

${ }^{84}$ O Programa de Despoluição da Baía de Guanabara (PDBG) foi iniciado em 1994 com financiamento do Banco Interamericano de Desenvolvimento (BID) e do Banco Japonês para Cooperação Internacional. Em 2006 foi encerrado oficial sem resultados efetivos.A partir de 2007 o Governo do Estado do Rio de Janeiro reiniciou o programa. Apesar dos avanços, até o presente momento não foi eficientemente solucionado o problema de poluição da Baía de Guanabara. 
distritos industriais da RMRJ assumiram com o "desenvolvimento sustentável”. Um dos exemplos citados é o Distrito Industrial de Santa Cruz, implantado sob o 'Programa de Fomento ao Desenvolvimento Industrial Sustentável do Estado do Rio de Janeiro - Rio Ecopolo'.

Localizado no bairro de Santa Cruz, zona oeste do Rio de Janeiro/RJ, teve sua implantação sob o referido programa Rio Ecopolo em 2002, quando as empresas industriais que integravam o Distrito Industrial de Santa Cruz estabeleceram um termo de compromisso para manter um rumo de desenvolvimento sustentável. (PDAM, 2011, p.37).

Cabe ressaltar que o PDAM é anterior às fortes denúncias feitas pela Fundação Oswaldo Cruz de graves problemas de contaminação e poluição ocorridas nessa localidade, por conta do início do funcionamento da TKCSA. No relatório intitulado "Avaliação dos impactos socioambientais e de saúde em Santa Cruz decorrentes da instalação e da operação da empresa TKCSA", Dias et al. (2011) indicaram que o pó emitido pela siderúrgica, que está em funcionamento desde o segundo semestre de 2010 em Santa Cruz, contém substâncias tóxicas como silício, enxofre, manganês e outros. Os pesquisadores também citam no seu relatório todos os empreendimentos vinculados ao Arco (listados na figura 60) e comentam que eles "requerem uma efetiva fiscalização ambiental e avaliação dos impactos à saúde por parte dos órgãos públicos, de forma que as eventuais irregularidades cometidas no caso TKCSA não sejam recorrentes, trazendo riscos à saúde coletiva." (DIAS et al., 2011, p.51)

Apesar deste enorme risco, não há no Plano uma projeção que indique quantitativamente as consequências desses passivos nos diversos aspectos ambientais (poluição do ar, hídrica, etc.) da área de influência do Arco. Argumentando que o INEA é o órgão responsável pelo licenciamento de cada um desses empreendimentos, o PDAM (2011) simplesmente se exime de qualquer comentário ou avaliação sobre os impactos ambientais dos empreendimentos. Restringe-se apenas a citar os dados da FEEMA (2007), não apontando nenhuma nova informação sobre esses processos de licenciamento.

Com relação ao Arco Metropolitano, o Plano informa que diversos estudos apontam que tanto a fase de obras quanto o funcionamento da rodovia têm um alto potencial poluidor. Entre os fatores estão a poluição do ar e a poluição sonora, devido à previsão do grande fluxo de veículos, e também inúmeros problemas decorrentes do grande fluxo de carga perigosa. 
Quanto à poluição sonora, o Plano sugere formas de monitoramento e a utilização do espaço por tipos de usos que se adequem ao aumento de ruído e à poluição atmosférica. Já o RIMA, frisa que a redução de tais tipos de poluição não pode ser vista como "um fato a ser acompanhado" e sim como um "desafio a ser vencido".

Aparentemente, o PDAM busca "resolver" a questão dos ruídos e da poluição atmosférica priorizando a implantação de indústrias nas áreas próximas do Arco, para assim evitar que possíveis moradias sejam afetadas pelo ruído e pela má qualidade do ar proveniente da rodovia. Contudo, não é mencionado nada em relação à qualidade das condições de trabalho nessas futuras indústrias.

Quanto à poluição atmosférica, o estudo da FEEMA (2007) analisou os índices de emissões por fontes fixas (como indústrias, mineração e termelétricas) e por fontes móveis (como tráfego rodoviário, aéreo, marítimo e fluvial). Dentre as estações que registraram quase a totalidade das violações por ozônio, mais de 99\%, encontram-se instaladas na área de influência do polo petroquímico de Duque de Caxias e próximas a duas grandes rodovias: a Washington Luiz e a Rio-Teresópolis.

Ainda que o Programa de Controle da Poluição do Ar por Veículos Automotores (PROCONVE) tenha, a partir de 2009, estabelecido limites mais restritivos para emissões de poluentes, as taxas de emissão por fontes móveis vêm aumentando devido ao crescimento acelerado da frota de veículos ao longo dos últimos anos (PDAM, 2011).

O Plano também admite que os caminhões constituem uma das principais fontes de emissão de óxidos de nitrogênio. Ele ainda destaca a "necessidade urgente" de optarmos por modais menos poluentes com a troca da matriz energética. Dito isso, a construção de novas rodovias, como o AMRJ, poderia ser vista como mais um fator estimulador do crescimento da frota de veículos poluidores, que deve ser preterida em defesa ao estímulo de modais como ferroviário ou aquaviário.

Segundo o PDAM (2011), a RMRJ tem uma configuração geográfica e um sistema de circulação atmosférica que favorece a boa qualidade do ar. Mesmo assim, atualmente já existem diversas áreas com concentrações inadequadas de poluentes, em decorrência da concentração de indústrias, pessoas e veículos. Logo, já que o AMRJ induzirá justamente ao aumento desses três fatores geradores de poluição atmosférica, claramente ele acarretará uma piora do cenário atual. 
No que diz respeito à saúde, o documento exibe os péssimos indicadores hegemônicos da RMRJ e parece concordar com os estudos de Sol Garson Braule, ${ }^{85}$ que acredita que a poluição oriunda das operações no COMPERJ pode ter impactos negativos no já precário sistema de saúde pública do município de ltaboraí.

Ao estudar a poluição do ar, o PDAM admite que haverá um considerável acréscimo de emissões de poluentes no trecho da RMRJ pelo qual passará o Arco Metropolitano. Contudo, o plano se refere a esse aumento sempre ressalvando, como contraponto, a possível diminuição da poluição do ar nos trechos da Avenida Brasil e Ponte Rio-Niterói.

Desta forma, o Plano busca uma visão macro espacial da poluição atmosférica da região metropolitana para ressaltar os "efeitos positivos" da criação do Arco, valorizando esse "deslocamento/redistribuição" da poluição. Como já vimos aqui, esse suposto alívio do tráfego é bastante falho. Tal alívio não ocorreu e ainda estima-se que, com a instalação de novas indústrias e a urbanização de novas áreas, teremos um aumento substancial da frota total de veículos na RMRJ.

Como medidas ambientais sobre a qualidade do ar e emissão de ruídos, poeiras e gases por parte do ARMJ, o RIMA (2007) propõe ações práticas a serem realizadas durante a fase de obras. Tais ações visam a proteção do trabalhador na obra da rodovia e pontuam as possibilidades de mitigação dos problemas gerados pela construção do Arco. No entanto, na fase de operação da rodovia, o Relatório seguiu a linha do Plano e identificou somente a necessidade de monitoramento e o respeito às normas existentes.

Sobre os riscos de acidentes rodoviários com cargas perigosas, o RIMA (2007) propõe diversas medidas ambientais, tanto para a fase de obra, quanto para a fase de operação da rodovia. Entre estas medidas está a criação de diversos programas ambientais. Contudo, a maioria delas estava voltada para a fase de obras.

Devido ao fluxo de carga perigosa, o PDAM lembra que o risco de acidentes de grande impacto poluidor estará presente em todo o trajeto do Arco. Este risco existirá durante todo o seu tempo de operação, podendo potencializar riscos de incêndios em áreas vegetadas, contaminar solo dos terrenos lindeiros e, ainda, contaminar mananciais atravessados e/ou nascentes próximas à rodovia, com reflexos negativos sobre a biota aquática.

\footnotetext{
${ }^{85}$ Nesse trecho o PDAM aproveita dados organizados na tese de doutorado da economista Sol Garson Braule Pinto intitulada "Regiões Metropolitanas: Obstáculos institucionais a cooperação em políticas urbanas", defendida no Instituto de Pesquisa em Planejamento Urbano e Regional da UFRJ no ano de 2007.
} 
Capítulo 5 


\section{Capítulo 5:}

\section{Considerações finais}

Como vimos, o Arco Metropolitano é uma peça fundamental de um grande projeto econômico neodesenvolvimentista para a RMRJ. 0 discurso daqueles que defendem o Arco aponta que os investimentos públicos na construção dessa rodovia se justificam, sobretudo, por dois grandes motivos. 0 primeiro é a necessidade de escoamento da produção do novo Complexo Petroquímico da Petrobras no estado do Rio de Janeiro (COMPERJ) pelo porto de Itaguaí. O segundo é a diminuição do fluxo de veículos de carga em importantes vias metropolitanas, principalmente na Avenida Brasil e na Ponte Rio-Niterói.

Contudo, mostramos aqui que há a possibilidade de a Petrobras não usar a rodovia como forma principal de escoamento da sua produção, uma vez que está construindo o seu próprio porto e sua própria estrada em localidade consideravelmente mais próxima que Itaguaí, a praia de ltaoca, em São Gonçalo.

Quanto à suposta melhoria do fluxo na Avenida Brasil e na Ponte Rio-Niterói, entendemos que toda nova via traz algum alívio para as vias existentes no seu entorno. Contudo, no caso do Arco, não há dados consistentes e nem uma análise profunda que possa afirmar que este alívio seja significativo. Além disso, mostramos aqui que o transporte de carga representa apenas 1\% das viagens motorizadas da RMRJ (PDTU, 2010) e que essas vias já possuem restrições aos veículos de cargas nos horários de maior fluxo.

Como já abordado, o AMRJ não é uma medida que trará benefícios quanto à mobilidade urbana da população que habita a região metropolitana. 0 Arco é uma rodovia que facilita apenas o transporte de cargas, que hoje enfrenta trânsito lento e restrições de horários nas vias de cidades populosas da RMRJ, como Rio de Janeiro e Niterói. Além disso, em um possível cenário de considerável aumento industrial futuro, o Arco será uma via importante para atender às demandas logísticas dessas novas indústrias e para minimizar os impactos dessa nova demanda nas vias existentes.

Nas duas justificativas citadas, percebemos o uso do discurso ideológico. Busca-se a legitimação do Arco por meio de duas ideias. A primeira induz que a rodovia é fundamental para o crescimento de uma grande empresa cujo acionista majoritário é o governo brasileiro. A segunda se refere à suposição que esta obra trará melhoria da mobilidade da população 
fluminense. Embora nenhuma dessas ideias seja de fato consistente elas são de grande apelo popular. Assim, cabe levantar a dúvida sobre a real intenção dessas justificativas.

Os argumentos em defesa do Arco se encaixam perfeitamente no conceito de ideologia, pois visam à aceitação de um empreendimento como o Arco construindo uma argumentação com base em ideias equivocadas e invertidas (MARX E ENGELS, 1989). 0 discurso ideológico sobre a melhoria do fluxo na Ponte e na Av. Brasil não contém a real história do problema da mobilidade urbana, mas faz uma alusão a ele para ganhar legitimidade. Tal discurso possui veracidade, mas deturpa a realidade sobre o transporte de cargas, como se o Arco fosse beneficiar toda a população.

Entretanto, como já vimos anteriormente, entre os principais beneficiados estão os "empreendimentos aderentes" ao Arco e as indústrias que, futuramente, poderão se instalar na região. Estima-se uma considerável redução nos custo com transporte decorrente apenas da implantação da rodovia. Assim, além destes empreendimentos, os empresários de produtos de baixo valor agregado também lucrarão com a criação do Arco, pois o custo do transporte influencia consideravelmente no valor final do produto.

Logo, estas ideias de beneficio de mobilidade para população e de necessidade fundamental para uma empresa com capital estatal, apesar de serem pouco consistentes, se consolidaram como verdadeiras e concretas, tendo sido pouco contestadas. Com isso, podemos ver claramente que as principais justificativas para a construção do Arco têm caráter de mito, uma vez que não são baseadas na coerência e na racionalidade, tendo apenas respaldo imaterial e subjetivo (CHAUl, 2000).

De forma combinada, os investimentos no porto de Itaguaí e no Arco trarão uma série de facilidades e oportunidades econômicas para diversas empresas que venham a se instalar no entorno do Arco. De acordo com o PDAM (2011), cabe destacar que o Arco e os investimentos no porto de Itaguaí beneficiam, sobretudo, empresas dos setores portuário, logístico, petroquímico, siderúrgico, químico, de mineração, de óleo e de gás. Além disso, nesse cenário, também se beneficiam desses investimentos públicos empresas de engenharia que se dedicam a grandes obras, como por exemplo à construção de rodovias, e que atuam em obras de engenharia especializadas em fornecimento de material, construção e montagem de indústrias desses setores.

Talvez não coincidentemente, estes tipos de empresas foram as que mais contribuíram com recursos na campanha política do ex-governador Sérgio Cabral (do Partido do Movimento Democrático Brasileiro - PMDB), eleito pela primeira vez no ano 
anterior ao anúncio do AMRJ. Cerca de 50\% da receita da campanha de Sérgio Cabral de 2006 foi financiada com recursos de construtoras contratadas na obra do AMRJ (16\%); empresas do setor de petroquímica, de óleo e gás, de mineração, sucroalcooleiro (16\%); empresas vinculadas ao setor de navegação (7\%); e companhias de engenharia especializadas em construções para esses setores citados (11\%).

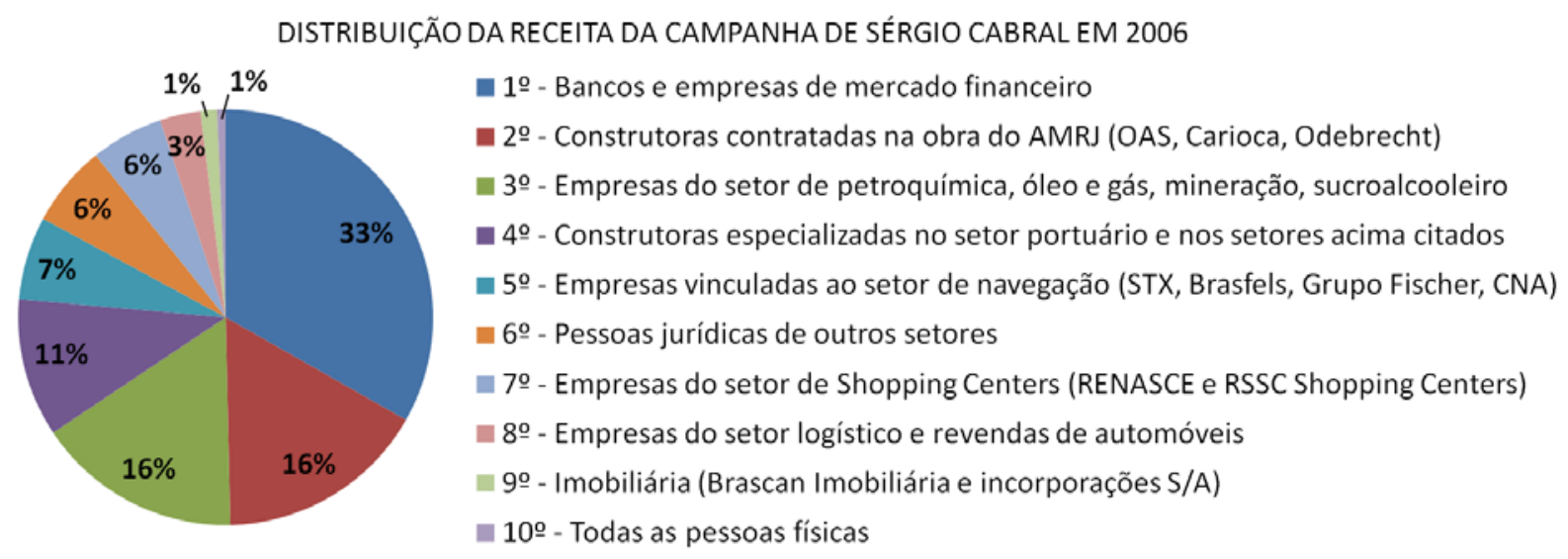

Figura 61 - A distribuição da receita da campanha de Sérgio Cabral nas eleições para governador do estado do Rio de Janeiro em 2006. Fonte: Elaboração própia com base no SITE DO TSE (2006).

Vemos assim um viés patrimonialista no qual o "interesse público" e os interesses privados do Sr. Sergio Cabral de retorno às empresas que investiram na sua campanha eleitoral se convergem na contratação de algumas delas para a construção do Arco Metropolitano ou no beneficiamento de outras, após a conclusão da obra.

Dessa campanha, também destacamos a participação da empresa Brascan, do ramo imobiliário, que doou cento e vinte e cinco mil reais à campanha. Esta empresa tem investido bastante nas áreas de influência do Arco Metropolitano. Antes mesmo do Arco ficar pronto, em 2008, a empresa já havia comprado grandes terrenos no município de Maricá,um deles chegando a ter oito milhões de metros quadrados (CONTE, 2008).

Nesse sentido, em alguns discursos (RIMA, 2007; SITE DO PLANALTO, 2014) também notamos que o Arco tem como objetivo dar acesso a áreas da RMRJ ainda não urbanizadas, valorizando inúmeros terrenos rurais ou vazios. Assim, essa rodovia expande o mercado imobiliário e proporciona uma grande oportunidade locacional de baixo custo para empresas que buscam grandes terrenos com facilidades de escoamento de produção.

Notamos, então, o fenômeno da máquina de crescimento urbano, no qual há a coalizão de forças de diversos setores que têm algo a ganhar com o "crescimento" de determinada região. No caso do Arco, diversos setores industriais se unem a setores imobiliários, logísticos e de construção, financiando uma campanha eleitoral em busca de 
poder político para alcançar seus interesses financeiros.Contudo, para implantar suas ideias, esses setores econômicos precisam fazer com que elas pareçam verdadeiras e justas, mantendo-se aparentemente como a defensora do interesse coletivo, dando aos seus pensamentos a forma de universalidade (VILLAÇA, 1999).

Com esse intuito, os documentos públicos do Arco e os grandes veículos de notícias propagam a ideia de que, apesar de todos os malefícios, o Arco é uma obra benéfica a toda a população devido à sua grande geração de emprego. Entretanto, podemos dizer que esse argumento é apenas parcialmente verdadeiro. Como vimos, dos oitocentos mil empregos propagandeados, apenas 1,35\% está de fato previsto pela operação dos empreendimentos do PAC. Destes 1,35\% apenas 14\% se referem a empregos diretos de longa duração referentes à operação dos empreendimentos, enquanto 86\% são oportunidades de curto prazo relacionadas a etapas de obras destes empreendimentos.

Desta forma, na argumentação do Arco sobre a criação empregos, podemos ver que o discurso ideológico se baseia em um fato real, lógico e coerente, mas amplia esse benefício de forma que pareça muito maior do que de fato o é. Chauí (1980) já alertava que a ideologia não é uma invenção gratuita, fantasiosa e arbitrária. Ela sempre possui uma base real, porém, normalmente está de ponta-cabeça. Assim, propagandeia-se de forma exacerbada a criação de empregos ao mesmo tempo que se camuflam fatos sociais que prejudicam a manutenção dessa ideia, distorcendo a realidade para implantar um projeto que na verdade é um objetivo financeiro das classes dominantes.

Ainda em relação à questão da geração de empregos presente no discurso do Arco, podemos dizer que ela se relaciona com a concepção de mito de Furtado (1974). Sua função principal é, a partir de um fato verossímil, orientar, nortear um processo social, influenciando o pensamento da população fluminense. E, bem como um farol na escuridão, ao mesmo tempo em que ilumina um determinado campo de percepção, obscurece e até inviabiliza a visão de outras questões.

Um das questões obscurecidas por este argumento é o caso dos pescadores artesanais da baía de Sepetiba. Em contraponto com a criação de empregos, estes pescadores vêm perdendo cada vez mais suas possibilidades de trabalho. Ao mesmo tempo que viabilizam a entrada de navios cada vez maiores, as dragagens na baía de Sepetiba e obras no porto de ltaguaí levantam lama e movimentam as águas, criando um local inóspito para os peixes. Nos últimos anos ocorreu também uma diminuição das áreas permitidas às atividades destes pescadores. Este acontecimento gerou problemas de saúde devido ao fato 
de que agora eles precisam pescar em localidades mais longínquas e, consequentemente, passar mais tempo no mar. Além disso, esse cenário se agrava ainda mais quando analisamos o risco de colisão que os pequenos barcos dos pescadores sofrem por ter que dividir o espaço náutico com um crescente fluxo de embarcações de grande porte.

Constatamos na nossa pesquisa que os principais meios de divulgação do Arco (PDAM, 2011; RIMA, 2007; SEOBRAS, 2013; SITE DO PLANALTO, 2014) tratam as questões aqui colocadas com acuidades diferentes. Enquanto a geração de emprego ganha um grande destaque, os malefícios para a população local dificilmente são mencionados. Assim, cria-se uma imagem de que as empresas que irão se instalar ao longo do Arco são a única ou a melhor forma de geração de empregos e renda para a região.

Chauí (1980) aborda esse tipo de narrativa de visão unilateral pontuando que uma das características do discurso ideológico é a elaboração de histórias nas quais são enaltecidos os "poderosos" e os "vencedores", e se oculta os trabalhadores, os servos, os escravos justamente como forma de legitimar a dominação da classe dominante. A autora menciona que os dominados aparecem nos textos ideológicos sempre a partir do modo como eram vistos e compreendidos pelos vencedores. Deste ponto de vista deturpado, a história dos "grandes feitos" e dos "grandes progressos" é contada sem elucidar o que são esses "grandes”, sobretudo sem esclarecer: Grandes em relação a quê? E grandes para quem? Ela acrescenta ainda que essa "grandeza” dos “grandes e poderosos"sempre depende da exploração e dominação dos “pequenos”.

Nesse sentido, observamos que em todos os discursos analisados, em meio à exaltação das novas e grandes indústrias, não há espaço para o debate sobre as consequências para os pescadores tradicionais ou para as comunidades quilombolas existentes na região e muito menos para os pequenos produtores rurais que hoje ocupam terras que interessam aos grandes agentes imobiliários e, futuramente, às novas indústrias.

Conforme falamos no primeiro capítulo, é importante aqui questionar o estado patrimonialista brasileiro e a atuação de certos "representantes do povo" mas também lembrar, conforme Marx e Engels (1989) que, na história mundial, os Estados, independente de sua época, sempre defenderam os interesses das classes dominantes. Nesse sentido, Villaça (1999) mostra que o planejamento urbano e regional foi um instrumento destes Estados, apresentando um discurso ideológico para legitimar os interesses das classes dominantes, camuflando-os como propostas necessárias para beneficiar toda a população. 
Assim, para oficializar suas ideias como interesse de Estado, essa "máquina de crescimento urbano" por trás do Arco busca legitimação perante a sociedade, usando como argumento a geração de empregos e a possibilidade de gerar divisas com os impostos. Tais impostos poderiam ter rebatimentos sociais, se fossem aplicados em benefício da coletividade. No entanto, ainda que o Arco seja um grande vetor de crescimento econômico da RMRJ, é importante lembrar que crescimento econômico não indica necessariamente distribuição de renda e nem melhoria socioambiental. Pelo contrário, o desenvolvimento puramente econômico pode, inclusive, gerar problemas socioambientais (FURTADO, 1974). Ainda que muito se fale desse crescimento industrial, pouco se fala sobre a já precária situação da infraestrutura da região. Nenhum estudo governamental se debruça sobre os impactos desse crescimento nas redes de infraestrutura existentes.

Essa falha ocorre inclusive no PDAM, que foi concluido posteriormente a estudos acadêmicos como o de Carneiro (2009). 0 autor já alertava para os problemas da expansão do perímetro urbano feita de forma desacompanhada de melhorias na infraestrutura e nos serviços básicos dos municípios da Baixada Fluminense. Este documento elaborado sob coordenação do Governo do Estado do Rio de Janeiro e com recursos Federais, comodamente, direciona para os frágeis organismos municipais a responsabilidade de ações que solucionem tais questões estruturais.

Cabe ressaltar que os municípios cortados pelo Arco já apresentam hoje péssimas condições de abastecimento de água, de esgotamento sanitário (FIRJAN, 2011), de pavimentação, iluminação, coleta de lixo e saúde (PDAM, 2011). Se levarmos em conta o ocorrido nos municípios cortados pela rodovia Rio-Santos (FIRJAN, 2008), a tendência é que no entorno do Arco esta situação de precariedade se acentue ainda mais nos próximos anos. Carneiro (2012), por exemplo, alerta que o Arco influencia no aumento da mancha urbana e, consequentemente, intensifica a degradação ambiental e a impermeabilização dos solos. 0 aumento dos espaços metropolitanos impermeabilizados tem sérios impactos na frequência e na intensidade das inundações.

Os desmatamentos decorrentes da construção do Arco e da expansão urbana por este gerada também provocam impactos negativos na preservação da biodiversidade. Como vimos, no caso da Floresta Mario Xavier, ainda que um trecho vegetado não tenha preservação relevante por sua flora, ele pode abrigar espécies da fauna brasileira ameaçadas de extinção. lsso se agrava quando há indícios de que, apesar de termos no Brasil rigorosas lei ambientais, estas leis são desconsideradas por simples questões comerciais que 
beneficiam apenas a determinados grupos. Um exemplo aqui relatado é o caso da rã Physalaemus Soaresi que teve seu habitat prejudicado em prol da viabilidade da ampliação da cobrança de pedágio.

Conforme vimos anteriormente, uma provável consequência do Arco será o aumento nos índices de poluição dos municípios cortados pelo Arco. lsso poderá ocorrer tanto pelo uso da rodovia como pela ocupação do seu entorno. Além de ser o meio de transporte que apresenta a menor eficiência energética, o modal viário é o que mais emite poluentes na camada atmosférica (PDAM, 2011). Ademais, acidentes de trânsito envolvendo o transporte de cargas perigosas podem ocasionar poluição do solo, dos rios e córregos cortados pela rodovia, além de contaminação dos lençóis freáticos do entorno da mesma. Agravando esse cenário, devemos também lembrar que todos os "empreendimentos aderentes" são de alto potencial poluidor (FEEMA, 2007).

Mesmo cientes de toda problemática da poluição, os discursos governamentais dizem ter como objetivo o "desenvolvimento sustentável". Essa contradição entre o discurso da "sustentabilidade" e o alto potencial poluidor nos remete ao trecho no qual MARX e ENGELS(1989) afirmam que, em toda a ideologia, os homens e suas relações nos aparecem de cabeça para baixo, como em uma câmera escura,na qual, exatamente como a inversão dos objetos na retina, a ideologia trabalha com uma visão invertida do real. Os autores concluem que, com a inversão de processos, são criados discursos de frases ocas com uma coleção de fatos sem vida e desvinculadas da história real.

Quanto à problemática da infraestrutura, o discurso do Arco também se comporta como ideológico ao explorar a ideia de industrialização e de expansão urbana descontextualizadas da realidade histórica e social de péssimas condições de infraestrutura básica. Colocando a cargo das frágeis municipalidades a resolução desse problema, o Plano do Arco manipula a inserção da ideia de "desenvolvimento" para que ela passe a ser a versão da realidade que se quer impor, se configurando assim como uma ideologia.

Pelos pontos apresentados acima, percebemos claramente que o Arco é uma obra que beneficia a poucos e traz malefícios para a população de forma geral. Contudo, conforme colocado por Marx e Engels (1989), o discurso ideológico é usado para que as classes dominadas não fiquem indignadas e não se insurjam contra a classe dominante. Nesse intuito, o discurso ideológico se encarrega de ocultar as divisões e as diferenças sociais e de reconstruir de modo invertido, abstrato e imaginário a ideia da classe 
dominante. Porém, no concreto, tal ideia não se mantém, não se fundamenta e, por isso,permanece sempre no plano imediato do aparecer social (CHAUÍ, 1980).

Essa noção de discurso ideológico explica o porquê dos documentos governamentais não entrarem no debate profundo sobre infraestrutura básica, mas sempre citarem o "risco da favelização”. Seguindo o ponto de vista das classes dominantes, o PDAM (2011) não problematiza a desigual oferta de infraestrutura nas cidades brasileiras e se limita a citar que a provável "favelização" pode agravar problemas sociais e aumentar os índices de violência urbana.

Infelizmente, esse tipo de tratamento dado às favelas não é peculiar do PDAM. Nabil Bonduki $^{86}$, em seu livro “Origens da Habitação Social no Brasil”, de 1998, já demonstrou como as favelas eram marginalizadas pelo Estado no início do século XX, sendo vistas como ameaça para toda a população por serem locais de proliferação de doenças e berços do vício e do crime. Ao focar nas consequências da existência de favelas e não nas suas causas, o discurso ideológico omite que a existência do problema habitacional e dos fatos que decorrem dele é fator inerente a um sistema capitalista que se mantém pela exploração de trabalhadores e pela omissão do Estado na resolução das questões de infraestrutura básica e habitação.

Althusser (1970) afirma que o discurso ideológico é uma invenção impregnada de ilusão e fabricada por uma classe que se baseia na alienação da divisão social do trabalho para ter legitimidade. Esse discurso faz alusão à realidade, se conformando como um reflexo pálido e vazio da sociedade. Também trabalhando esse distanciamento entre a realidade das comunidades de baixa renda com o modo de produção da sociedade, Chauí (1980) coloca que a definição da liberdade como igual direito de escolha é a ideia burguesa da liberdade e não a realidade histórico-social da liberdade. Com isso a autora indaga:

Todos podem realmente escolher o que desejarem? 0 nordestino, vítima da seca e do proprietário das terras, realmente "escolhe" vir para o sul do país? Escolhe viver na favela? 0 peão metalúrgico "escolheu" livremente fazer horasextras depois de 12 horas de trabalho? (CHAUl, 1980, p.89).

A autora ainda afirma que também é parte do papel da ideologia fazer com que aquelas ideias "verdadeiras", criadas pela classe dominante, não só sejam absorvidas e acreditadas por todos, como também sejam vistas como ideias autônomas. Por essa noção

\footnotetext{
${ }^{86}$ No livro Origens da habitação social no Brasil. Arquitetura moderna, lei do inquilinato e difusão da casa própria. Editora Estação Liberdade. São Paulo. 1998.
} 
de autonomia, estas ideias não dependem de ninguém e são representantes da realidade, pois não foram feitas por ninguém.

Dessa mesma forma, a valorização fundiária e a gentrificação de localidades, como a região portuária de ltaguaí, são vistas como acontecimentos naturais e autônomos. Nestes acontecimentos não é citada a ação dos interesses industriais e portuários nessa área e as sucessivas restrições impostas ao meio de sobrevivência dos pescadores artesanais desse local.

Ao analisar "A Ideologia Alemã" (MARX E ENGELS, 1989), Althusser (1970) faz uma proposição aparentemente paradoxal: a ideologia não tem história. Com esta frase, o autor mostra que a ideologia não é história, mas é uma faceta da história, já que toda a sua realidade está propositalmente fora de si mesma. A ideologia não passa de uma falsa realidade, uma representação imaginária do mundo, tendo como único ponto de vista o da classe dominante. Sendo assim, ela é uma visão deturpada e invertida da sociedade. Ao mesmo tempo, o discurso ideológico tem como pano de fundo a história da luta de classes, vista por Marx, Engels e Althusser como a história constante da sociedade.

Ao analisarmos o caso do Arco, percebemos que ele se encaixa perfeitamente nessa concepção de ideologia colocada por estes autores. Assim, podemos dizer que os discursos governamentais do Arco se enquadram como um elemento do aparelho ideológico do Estado, nos quais se adota a ideologia da classe dominante assegurando a opressão de classe e garantindo as condições da exploração e da reprodução desta (ALTHUSSER, 1970).

Conforme mostramos ao longo desta dissertação, os discursos governamentais do Arco invertem aspectos da realidade social da RMRJ, deturpam os impactos sociais dessa nova rodovia e omitem questões político-econômicas e socioambientais fundamentais para o debate da necessidade e dos custos materiais e imateriais dessa obra. Esse esvaziamento de questões conflituosas também é característico dos discursos ideológicos. Nestes, ocultase parte da realidade, já que ela põe em risco a ideologia e, consequentemente, os objetivos da classe dominante em determinar aos demais membros da sociedade o que e como pensar, valorizar e fazer.

Sendo assim, por vezes é necessário criar lacunas e omissões como forma de sustentação, uma vez que se toda a verdade fosse dita, o discurso ruiria de dentro para fora. Desta maneira, para ocultar a verdade sem perder coerência racional, a ideologia precisa da existência de "brancos", de "lacunas" ou de "silêncios" que nunca poderão ser preenchidos 
para não perder sua frágil coerência ideológica. Estes "brancos propositais" ou "vazios programados" são responsáveis pela coerência racional (CHAUí, 1980).

Pelo exposto, notamos que os discursos de justificativa de implantação do AMRJ ocultam o conflito de classes, ainda que suas entrelinhas deixem visível a história da luta de classes. Por intermédio governamental, esses discursos apresentam, de forma impositiva, determinações sobre a construção da rodovia, não sendo composto por um amplo debate entre os diversos atores da sociedade. Assim, os discursos oficiais sobre o Arco apresentam apenas o ponto de vista da classe dominante, não representando os interesses da totalidade da população, por não conter os interesses das classes dominadas. Seguindo a linha do raciocínio de Chaui (1980), se estes discursos não deixassem essas lacunas, talvez eles não existissem. Bem como a obra do Arco, perderia o peso das suas duvidosas justificativas e, com ele, talvez, perderia também a aceitação da sua razão de ser.

Ao final dessa dissertação a questão que se abre é: será o Arco a única obra do período neodesenvolvimentista com essas características ou esta nova conjuntura política econômica brasileira repete esse padrão em outros empreendimentos brasileiros? Poderíamos dizer isso também do Rodoanel Mario Covas, do Porto Maravilha, do Porto de SUAPE ou do Rodoanel da Região Metropolitana de Recife?

Terminamos essa análise do Arco Metropolitano do Rio de Janeiro apontando que é necessário avaliar se, no Brasil, podemos dizer que as políticas de estruturação territorial e urbanas são movidas, preponderantemente, pelo discurso ideológico do neodesenvolvimentismo, mesmo que, na prática, isso não resulte em melhorias concretas dos problemas socioespaciais e sim no favorecimento de interesses específicos. Caso isso se comprove, o neodesenvolvimentismo terá se fortalecido politicamente por um viés patrimonialista no contexto da "máquina de crescimento urbano" e não pelo atendimento das reais necessidades da população. 


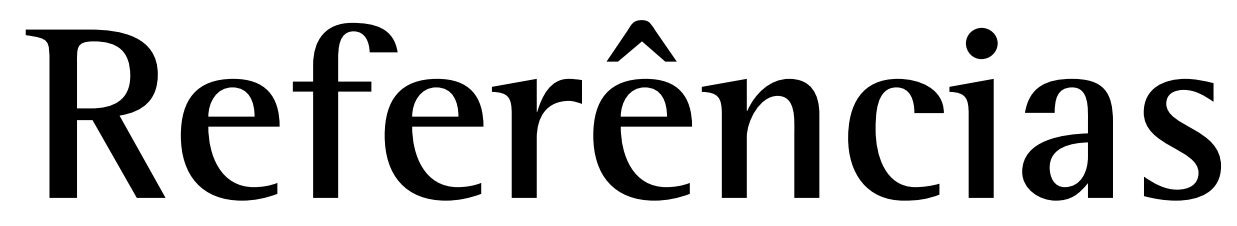

Bibliográficas 


\section{Referências Bibliográficas}

- ACSELRAD, Henri. Ambientalização das lutas sociais - o caso do movimento por justiça ambiental. Revista Estudos Avançados, vol.24, $n^{\circ} 68,2010$, Disponível em: <http://www.scielo.br/pdf/ea/v23n68/10.pdf>. Acesso em fevereiro de 2015.

- ACSPR-RJ - Assessoria de Comunicação Social da Procuradoria da República no Rio de Janeiro. MPF/RJ realiza audiência pública para debater impactos ambientais. Notícia com convocatória e edital publicados no Site do Ministério Público Federal em 26 de Setembro de 2012. Disponível em: <http://noticias.pgr.mpf.gov.br/noticias/noticias-dosite/copy_of_meio-ambiente-e-patrimonio-cultural/mpf-rj-realiza-audiencia-publicapara-debater-impactos-ambientais-do-arco-metropolitano/?searchterm=Physalaemus $>$. Acesso em Maio de 2013.

- AGÊNCIA BRASIL. Audiência pública debate impactos ambientais da construção do Arco Metropolitano do Rio. Notícia editada por Aécio Amado e publicada em 8/10/2012 no Site da Agência Brasil. Disponível em: <agenciabrasil.ebc.com.br/ noticia/2012-10-08/audiencia-publica-debate-impactos-ambientais-da-construcao-doarco-metropolitano-do-rio>. Acesso em Julho de 2013.

- AlTHUSSER, Louis. Aparelhos Ideológicos do Estado. Editora Presença / Martins Fontes, Lisboa, 1970.

- AULER, Marcelo. Delta diz que "sítio arqueológico" impediu obra no Arco Metropolitano. Portal de notícias do Jornal do Brasil, 12/09/2012 às 18h39 - Atualizada em 13/09/2012 às 12h08. 2012b Disponível em: < http://www.jb.com.br/rio/noticias/2012/09/12/delta-diz-que-sitio-arqueologicoimpediu-obra-no-arco-metropolitano/>. Acesso em janeiro de 2015.

- BERTA, Ruben. Decreto libera uso de área de preservação para obras do Arco Metropolitano. 02/08/2011 0:00, atualizado 03/11/2011 17:36. Rio de Janeiro. Portal de notícias do jornal 0 GLOBO. Disponível em: <http://oglobo.globo.com/rio/decretolibera-uso-de-area-de-preservacao-para-obras-do-arco-metropolitano-2708116>.

Acesso em maio de 2014.

- BERTUCCI, Ademar de Andrade; LEROY, Jean-Pierre; ACSELRAD, Henri; PÁDUA JA, SCHLESINGER Sérgio, PACHECO, Tânia. Tudo ao Mesmo Tempo Agora: Desenvolvimento, Sustentabilidade, Democracia o Que lsso Tem a Ver com Você ? Editora Vozes, Petrópolis, 2002. 
- BlOG DO PlANAlto (da Presidência da República), Arco Metropolitano diminuirá tráfego nas principais vias do Rio de Janeiro, 1 de julho de 2014. Disponível em: $<$ http://blog.planalto.gov.br/arco-metropolitano-diminuira-trafego-nas-principais-viasdo-rio-de-janeiro/>. Acesso em janeiro de 2015.

- BONDUKl, Nabil. Origens da habitação social no Brasil. Arquitetura moderna, lei do inquilinato e difusão da casa própria. Editora Estação Liberdade. São Paulo. 1998.

- BOTTARl, Elenilce. Obra de Arco Metropolitano não tem sequer $1 \mathrm{~km}$ de asfalto. Portal de notícias do Jornal 0 Globo. Rio de Janeiro. 7 de outubro de 2012. Disponível em: $<$ oglobo.globo.com/rio/obra-de-arco-metropolitano-nao-tem-sequer-1 km-de-asfalto6311068>. Acesso em novembro de 2013.

- BOURSCHEIT (2009b), Aldem. Uma rã carioca marcada para morrer. Matéria publicada no site "o eco" em 17 de julho de 2009. Disponível em: <www.oeco.com.br/reportagens /22155-uma-ra -carioca-marcada-para-morrer>. Acesso em Maio de 2013.

- BOURSCHEIT, Aldem. Mais uma espécie ameaçada pelo PAC. Matéria publicada no site "o eco" em 03 de agosto de 2009. Disponível em: <http://www.oeco.org.br /reportagens/22242-sobram-duvidas-sobre-mario-xavier>. Acesso em julho de 2013.

- BRAGANÇA, Daniele. Petrobras não poderá usar rio Guaxindiba para transporte. Reportagem do site 0 ECO, 17/01/13. Disponível em: <http://www.oeco.org.br/saladaverde/26841-petrobras-nao-podera-usar-rio-guaxindiba-para-transporte>. Acesso em janeiro de 2015.

- BRASIL, Ministério das Cidades - Secretaria Nacional de Habitação \&t Fundação João Pinheiro. Déficit Habitacional no Brasil- municípios selecionados e macrorregiões geográficas. Brasília: Ministério das cidades, 2010. Dados obtidos através do programa: Instalador do Déficit Habitacional Referência 2010, edição editada no dia 28 de maio de 2014. Disponivel em <http://www.fjp.mg.gov.br/index.php/produtos-eservicos1/2742-deficit-habitacional-no-brasil-3> Acesso em janeiro de 2015.

- BRESSER-PEREIRA, Luiz Carlos. A quase-estagnação brasileira e sua explicação novodesenvolvimentista. Artigo para Seminário Indústria e Desenvolvimento Produtivo do Brasil realizado na Escola de Economia da Fundação Getúlio Vargas. São Paulo. Maio de 2014. 
- BRESSER-PEREIRA, Luiz Carlos. Estado desenvolvimentista, nacionalismo e liberalismo Artigo para reunião anual da Sociedade Brasileira de Ciência Política, Gramado, agosto de 2012.

- CAPPELll, Paulo Arco Metropolitano vai gerar 10 mil empregos. Portal de notícias do jornal 0 DIA, 01/07/2014. Disponível em: <http://odia.ig.com.br/odiaestado/2014-0701/arco-metropolitano-vai-gerar-10-mil-empregos.html>. Acesso em janeiro de 2015.

- CARDOSO, Adauto Lucio; ARAÚJO, Flávia de Sousa. A via expressa das políticas públicas no Rio de Janeiro: reflexões acerca dos impactos do Arco Metropolitano. In: Grandes Projetos Metropolitanos: Rio de Janeiro e Belo Horizonte. Editora Letra Capital. 2012.

- CARNEIRO, Paulo Roberto Ferreira. Impacto do Arco Metropolitano sobre a intensidade das inundações na Baixada Fluminense. In: Grandes Projetos Metropolitanos: Rio de Janeiro e Belo Horizonte. Editora Letra Capital. 2012.

- CARNEIRO, Paulo Roberto Ferreira. O Arco Metropolitano e o futuro da baixada fluminense. Artigo publicado no site do Observatório das Metrópoles. Setembro de 2009. Disponível em: <www.observatoriodasmetropoles.ufrj.br>. Acesso em Maio de 2013.

- CARSON, Rachel L. Primavera Silenciosa. Tradução Claudia Sant'Ana Martins. São Paulo: Gaia, 2010.

- CARVALHO, Marcela. Secretário de Desenvolvimento Regional participa de seminário sobre Arco Metropolitano. Notícia publicada no dia 18/04/2011 no site do governo do estado. Disponivel em: <http://www.rj.gov.br/web/sedrap/exibeconteudo?article-id $=427346>$. Acesso em março de 2012 .

- CAVAlCANTl, Clóvis. Meio ambiente, Celso Furtado e o desenvolvimento como falácia. Revista Ambiente e Sociedade. Vol. 5, $\mathrm{n}^{\circ}$ 2. Campinas, 2003. Disponível em: $<$ http://ref.scielo.org/2kpgxm>. Acesso em fevereiro de 2015.

- CEPERJ - Fundação Centro Estadual de Estatísticas, Pesquisas e Formação de Servidores Públicos do Rio de Janeiro>. Tabela de Produto Interno Bruto dos municípios do estado do Rio de Janeiro (entre 1999 e 2012). Disponível em: <www.ceperj.rj.gov.br/ ceep/pib/PIB_MUNICIPAL_1999_\%202012.xls>. Acesso em janeiro de 2015.

- CHAUI, Marilena. Convite à Filosofia. Editora Ática, São Paulo, 2000. 
- CHAUÍ, Marilena. O que é ideologia. Editora Brasiliense. Coleção Primeiros Passos. São Paulo, 1980.

- CONTE, Guilherme. Arco Metropolitano do Rio de Janeiro vira chamariz de investimentos em habitação e indústrias. Revista Construção \& Mercado. Maio de 2008. Disponível em: <http://ademi.webtexto.com.br/article.php3?id_article=26442>. Acesso em março de 2012.

- CRUZ, Renata. Construtoras investem em áreas cortadas pelo Arco Metropolitano. 01/03/2010. Site do Governo do Estado do Rio de Janeiro. Disponível em: <www.rj. gov. $\mathrm{br} / \mathrm{web} /$ seobras/exibeconteudo? article-id=176876>. Ultimo acesso em: Maio de 2013

- Dennis L. Meadows, Donella H. Meadows y Jorgen Randers. The limits to growth, $A$ Report for the club of rome's Project on the predicament of mankind. Universe Books, Nova lorque, 1972. Disponivel em: <http://www.donellameadows.org/wp-content /userfiles/Limits-to-Growth-digital-scan-version.pdf >. Acesso em fevereiro de 2015.

- Departamento de Estradas de Rodagem do estado do Rio de Janeiro (DER-RJ). Mapa rodoviário do estado do Rio de Janeiro. 2006. Disponível em: http://www.der.rj.gov.br/mapas_n/dowmap.htm Acesso em janeiro de 2015.

- Departamento de Estradas de Rodagem do estado do Rio de Janeiro (DER-RJ). AutoCad do AMRJ com imagens de satélite. Setembro de 2007

- DHESCA BRASIL. Audiência Pública "Impactos Ambientais da Construção do Arco Metropolitano do Rio de Janeiro". Notícia veiculada no Site da Plataforma Dhesca Brasil. 2012. Disponível em: <http://www.dhescbrasil.org.br/index.php?option=com _contentCtview=articleCtid=676:audiencia-impactos-ambientais-arcometropolitano\&tcatid=69:antiga>. Acesso em Maio de 2013.

- $\quad$ DIAS, Alexandre Pessoa; PORTO, Marcelo Firpo de Souza; MENEZES, Antonio Carneiro; BÚRIGO, André Campos. Avaliação dos impactos socioambientais e de saúde em santa cruz decorrentes da instalação e operação da empresa TKCSA. Relatório da Fundação Oswaldo Cruz, Escola Nacional de Saúde Publica e Escola Politécnica de Saúde Joaquim Venâncio. Rio de Janeiro. 22 de setembro de 2011. Disponível em: <http://www .epsjv.fiocruz.br/upload/d/Relatorio_TKCSA.pdf>. Acesso em janeiro de 2015.

- DIAS, Marcelo. Barcas Rio-Niterói têm a segunda tarifa mais cara do mundo. 12/03/13, 21:32. Disponível em: <http://extra.globo.com/noticias/rio/barcas-rio-niteroitem-segunda-tarifa-mais-cara-do-mundo-7790353.html>. Acesso em janeiro de 2015. 
- DUPAS, Gilberto. 0 mito do progresso. Artigo na revista Novos Estudos, $n^{\circ}$ 77, São Paulo, março de 2007. Disponível em: <http://www.scielo.br/pdf/nec/n77/ a05n77.pdf>. Acesso em fevereiro de 2015

- DUQUE DE CAXIAS, Câmara municipal de. Plano Diretor municipal. Lei Complementar n.01 de 31 de outubro de 2006.

- ESTEVES, Ricardo. 0 que esperar do Arco Metropolitano: Objetivos e Impactos. Duque de Caxias. Fevereiro de 2013. Palestra promovida pela Central de Cursos de Extensão da PUC-Rio. Disponível em: <http://www.slideshare.net/arqleoname/arcometropolitano-ricardo-esteves>. Acesso em fevereiro de 2013

- FAORO, Raymundo. Os Donos do Poder: Formação do Patronato Político Brasileiro. Rio de Janeiro, editora Globo, 1975, 3a edição 2001, revista.

- FCDDHBR - Fundação Centro de Defesa dos Direitos Humanos Bento Rubião. Avaliação Final Plano Diretor de Itaguaí. Rede de Avaliação e Capacitação para Implementação dos Planos Diretores Participativos (RACIPPP) parceria: IPPUR-UFRJ e Ministério das Cidades. 2008a.

- FCDDHBR - Fundação Centro de Defesa dos Direitos Humanos Bento Rubião. Avaliação Final do Plano Diretor de Magé. (RACIPPP) parceria: IPPUR-UFRJ e Ministério das Cidades. 2008.

- FCDDHBR - Fundação Centro de Defesa dos Direitos Humanos Bento Rubião. Avaliação do Plano Diretor de Guapimirim (RACIPPP) parceria: IPPUR-UFRJ e Ministério das Cidades. 2008.

- FERREIRA, João Sette Whitaker. Notas de aula "Les théories du " développementisme " et de la dépendance (de 1940 au néolibéralisme des années 1990)" realizada no curso "Territoires du développement et L'urbanisation en Amérique Latine" do Institut des Hautes Etudes de l'Amérique latine (IHEAL), Paris, 2012.

- FERREIRA, João Sette Whitaker. O Mito da Cidade-Global: o Papel da Ideologia na Produção do Espaço Urbano. Editora Vozes, Petrópolis, 2007.

- FERREIRA, João Sette Whitaker; FERRARA, Luciana (2012). A Formulação de uma Nova Matriz Urbana no Brasil, Baseada na Justiça Socioambiental. Artigo produzido para o Ministério das Cidades, Ministério do Meio Ambiente e ONU - Habitat para Diálogos da Rio+20, Rio de Janeiro, junho de 2012. 
- FlORI, José Luís. A Governabilidade Democrática na Nova Ordem Econômica. Novos Estudos Cebrap, n. 43, p.157 - 172, setembro de 1995. Disponível pelo Instituto de Estudos Avançados da Universidade de São Paulo em: <http://www.iea.usp.br /publicacoes/textos/fiorigovernabilidade.pdf>. Acesso em junho de 2014.

- FIRJAN (Federação das Indústrias do Estado do Rio de Janeiro). Avaliação de Impactos Logísticos e Socioeconômicos da Implantação do Arco Metropolitano do Rio de Janeiro. № 3, julho/2008. Resumo Executivo. Elaboração técnica: COPPEAD-UFRJ e Tendências Consultoria. Disponível em: <http://www.firjan.org.br/data/pages/2C908CE9 215B0DC40121793A16451EFC.htm>. Acesso em março de 2012.

- FIRJAN (Federação das Indústrias do Estado do Rio de Janeiro). Índice FIRJAN de Desenvolvimento Municipal. Disponível em: <www.firjan.org.br/ifdm>. Acesso em janeiro de 2015.

- FREITAS, Marcelo Bessa; RODRIGUES, Silvio Cesar Alves. As consequências do processo de desterritorialização da pesca artesanal na Baía de Sepetiba (RJ, Brasil): um olhar sobre as questões de saúde do trabalhador e o ambiente. Artigo publicado na revista Ciência \& Saúde Coletiva, vol.19 n¹0, Rio de Janeiro. Outubro de 2014. ISSN 14138123 13. Disponível em: <http://www.scielo.br/scielo.php?pid=S1413-81232014001004001ct script=sci_arttext $>$. Acesso em janeiro de 2015.

- FREITAS, Simone R. 0 papel das estradas na mudança da paisagem: 0 caso das florestas tropicais. Apresentação feita na VI Oficina Arquitetura da Paisagem e 111 Oficina Quapa-SELRJ. Rio de Janeiro, 2012.

- FURTADO, Celso. 0 mito do desenvolvimento econômico. Rio de Janeiro: Paz e Terra, 1974.

- G1 R10. Após pane, passageiros botam fogo em trem da Supervia em Bonsucesso. 11/09/2013. disponível no link: <http://g1.globo.com/rio-dejaneiro/transito/noticia/2013/09/apos-pane-passageiros-botam-fogo-em-trem-dasupervia-em-bonsucesso.html>. Acesso em janeiro de 2015.

- G1 Rl0. RJ lança operação especial de ônibus rodoviários para o carnaval. 03/02/2015 07h22. Disponível em: <http://g1.globo.com/rio-de-janeiro/noticia/2015/02 /rj-lanca-operacao-especial-de-onibus-rodoviarios-para-o-carnaval.html>. Acesso em março de 2015. 
- G1 R10. Saída para o feriado deixa trânsito lento na Ponte Rio-Niterói. 13/02/2015, 09h55. Disponível em: <http://g1.globo.com/rio-de-janeiro/transito/noticia/2015/02/ saida -para-o-feriado-deixa-transito-lento-na-ponte-rio-niteroi.html>. Acesso em março de 2015.

- GERBASE, Fabíola. Estado só fez 35\% dos 70,9 km do Arco Metropolitano, que ligará Itaboraí ao Porto de Itaguaí. Portal de notícias do Jornal 0 GLOBO. Rio de Janeiro. 21 de julho de 2011. Disponível em: <http://oglobo.globo.com/transito/estado-so-fez-35dos-709-km-do-arco-metropolitano-que-ligara-itaborai-ao-porto-de-itaguai-2713071>. Acesso em março de 2012

- GOOGLE EARTH. Programa de visualização de imagens de satélite. Período das imagens: de 2002 a 2015. Disponivel em: <http://www.google.com.br/earth/download /ge /agree.html>. Acesso em janeiro de 2013.

- GOOGLE STREET VIEW. Site de visualização de imagens de satélite. Período visualizado: de 2012 a 2014. Disponível em: <maps.google.com.br/maps>. Acesso em janeiro de 2013 .

- HARVEY, David. Do gerenciamento ao empresariamento: a transformação da administração urbana no capitalismo tardio. Espaço \&t Debates: Revista de Estudos Regionais e Urbanos, São Paulo, ano XVl,n. 39, p.48-64, 1996.

- HARVEY, David. Seventeen Contradictions and the End of Capitalism. Editora Profile Books. Londres, 2014.

- IPEA - Instituto de Pesquisa Econômica Aplicada. Renda - desigualdade - coeficiente de Gini Atualizado em: 04/11/2013. Disponível em: <www.ipeadata.gov.br>. Acesso em dezembro de 2014.

- ISIDORO, Inês; ALCANTARA, Denise de; TÂNGARl, Vera Regina. Uma inovação metodológica no estudo das unidades de paisagem: As Oficinas Locais nos municípios influenciados pelo Arco Metropolitano. Novembro de 2011. VI Colóquio QUAPÁ-SEL. Disponível em: <http://silviomacedo.files.wordpress.com/2011/11/artigo-9.pdf>. Acesso em: Maio de 2012

- JAPERl, Câmara municipal de. Plano Diretor do Município de Japeri. Lei Complementar n. 064 de 29 de março de 2006. 
- JORNAL DO COMMERCIO. Arco Metropolitano: ocupação desordenada preocupa empresários. Edição 14/05/2011. Disponível em: <http://ademi.webtexto.com.br/ article.php3?id_article=20364>. Acesso em: setembro-2012.

- JUNIOR, Orlando Alves dos Santos; MONTANDON, Daniel Todtmann (orgs.). Os planos diretores municipais pós-estatuto da cidade: balanço crítico e perspectivas. Editora Letra Capital, Observatório das Metrópoles do IPPUR/UFRJ. Rio de Janeiro. 2011.

- LINS, Marina Navarro. Inaugurado há 6 meses, Arco Metropolitano segue em obras. 19 de janeiro de 2015. Disponível em: < http://extra.globo.com/noticias/rio/inauguradoha-6-meses-arco-metropolitano-segue-em-obras-15090756.html>. Acesso em fevereiro de 2015.

- LOGAN, John R.; MOLOTCH, Harvey Luskin. Urban Fortunes: The Political Economy of Place. University of California Press, Berkeley, 1987.

- LOPES, Rafael; LOPES, Bianca; BALBINO, Aline. Manifestação contra aumento das barcas é mantida. Portal de notícias do Jornal O FLUMINENSE. 29/02/2012. Disponível em: <http://jornal.ofluminense.com.br/editorias/cidades/manifestacao-contra-aumentoda-barcas-e-mantida ultimo acesso em 06 de março de 2012>. Acesso em janeiro de 2013.

- MACHADO, Carlos José Saldanha. Por uma revisão das políticas públicas de construção de rodovias face aos danos ambientais caudados nas bacias hidrográficas. Portal de notícias do Jornal da Ciência - Órgão da Sociedade Brasileira para o Progresso da Ciência, Rio de Janeiro, v. 2348, 22 ago. 2003.

- MARCIANO, A.C. dos S., DA CUNHA, A.S., MORAES, C.F. de J. FURMAN, J.B. \& Sánchez, C. A Questão Ambiental e o Arco Metropolitano do Rio de Janeiro. TEKOA - Revista Virtual do Curso de Ciências Biológicas da Universidade Veiga de Almeida. Ano IV - $4^{\text {a }}$ edição. Junho de 2010.

- MARICATO, Ermínia. As idéias fora do lugar e o lugar fora das idéias. in A cidade do pensamento único: Desmanchando consensos. 3a Edição. Editora Vozes. Petrópolis. 2002. p.121-192

- MARX, Karl e ENGELS, Friedrich. A ideologia Alemã. Editora Martins Fontes. São Paulo. 1989. 
- MELLO, lgor. Delta abandonou Arco Metropolitano; obra está sem data para ser inaugurada. Previsão inicial da entrega era para 2010. Construtora nem montou canteiro de obras. Portal de notícias do Jornal do Brasil, 12/09/2012 às 06h51. Disponível em: <http://www.jb.com.br/rio/noticias/2012/09/12/delta-abandonou-arcometropolitano-obra-esta-sem-data-para-ser-inaugurada/>. Acesso em janeiro de 2015.

- MENDES, Taís. Em vez de 'bichoduto', Arco pode ganhar dois viadutos para proteger pererecas. Portal de notícias do Jornal O GLOBO. 25 de maio de 2010. Disponível em: <oglobo.globo.com/rio/em-vez-de-bichoduto-arco-pode-ganhar-dois-viadutos-paraproteger-pererecas-3002947>. Acesso em novembro de 2013.

- MENDONÇA, Alba Valéria. Além da perereca, outro bicho raro pode atrapalhar Arco Metropolitano. 30 de novembro 2009. Disponível em: <g1.globo.com/Noticias/Rio/0,M UL1322997-5606,00-ALEM+DA+PERERECA+OUTRO+BICHO+RARO+PODE+ ATRAPALHAR+ARCO+ METROPOLITANO.html>. Acesso em novembro de 2013.

- MENDONÇA, Alba Valéria; BRITO, Guilherme. Viagem pelo Arco Metropolitano leva mais tempo do que pela Av. Brasil: G1 testou via até o porto de ltaguaí e comparou com caminho convencional. Acesso pela BR-040 é confuso e com cones na pista. 02/07/2014, 12h25. Disponível em: <http://g1.globo.com/rio-de-janeiro/noticia/2014 /07/viagem-pelo-arco-metropolitano-leva-mais-tempo-do-que-pela-av-brasil.html>. Acesso em janeiro de 2014.

- MONTEZUMA, Rita. Conexões e Rupturas: a dupla face da mesma moeda. Duque de Caxias. Fevereiro de 2013 Palestra promovida pela Central de Cursos de Extensão da PUC-Rio. Disponível em: <http://www.slideshare.net/arqleoname/arco-metropolitanorita-montezuma>. Acesso em fevereiro de 2013.

- MORAES, Carolina. Afinal, a quem pertence o Arco Metropolitano do Rio de Janeiro? Texto veiculado no Site da Coordenação Central de Extensão da Pontifícia Universidade Católica do Rio de Janeiro (CCE-PUC-RJ). 7/2/2013. Disponível em: <www.cce.pucrio.br/noticias/arcometropolitanorj.html>. Acesso em Maio de 2013.

- MOTTA, Cláudio. Parque do Carbono: plantio de 2,6 milhões de árvores para compensar emissões de gases no estado. Portal de notícias do Jornal 0 GLOBO, 03/02/2011, atualizado 04/11/2011, 4:25. Disponível em: <http://oglobo.globo.com /rio/parque-do-carbono-plantio-de-26-milhoes-de-arvores-para-compensar-emissoesde-gases-no-2827732>. último acesso em novembro de 2013. 
- MOTTA, Fabio. ESTADO DE SÃO PAULO, Jornal. Título original da foto: Reflexo em fachada de prédio mostra o protesto contra o aumento da passagem de ônibus no Rio de Janeiro, pela Avenida Rio Branco, chegando ao Teatro Municipal, no centro da cidade. Outubro de 2013. Disponível em: <http://estadaofotos.tumblr.com/post/532279 84292/reflexo-em-fachada-de-predio-mostra-o-protesto>. último acesso em novembro de 2013.

- MÜLlER, Angélica Müller; DI SÁBATTO, Tatiana. Entrevista com Maria Augusta de Toledo Tibiriçá Miranda. Data da entrevista: 24/05/2005. Editora Relume, p. 5.

- NACIF, Cristina; NAME, Leonardo. Avaliação do Plano Diretor do Município Itaboraí. (RACIPPP) parceria: IPPUR-UFRJ e Ministério das Cidades. 2008.

- NATAL, Jorge. Inflexão econômica e dinâmica espacial pós-1996 no Estado do Rio de Janeiro. Revista nova Economia, Belo Horizonte, vol. 14, no 3, pp. 71-90, setembrodezembro de 2004. Disponível em: <http://www.face.ufmg.br/ novaeconomia/sumarios /v14n3/140303.pdf>. Acesso em fevereiro de 2015.

- NOVA IGUAÇU, Câmara Municipal de. Plano Diretor Participativo de Nova Iguaçu. Lei $n^{\circ}$. 4.092, de 28 de junho de 2011.

- 0 DIA. Abertura de estrada que liga ltaboraí a ltaguaí prevê criação de 800 mil empregos. 26 de junho de 2012. Disponível em: <http://odia.ig.com.br/portal/rio/o-diabaixada/estado-promete-arco-pronto-at\%C3\%A9-o-fim-do-ano-1.549479>. Acesso em janeiro de 2015.

- O DIA. Estado promete Arco pronto até o fim do ano. 25 de abril de $2012 \mathrm{~b}$. Disponível em: http://odia.ig.com.br/portal/rio/o-dia-baixada/estado-promete-arco-pronto-at\%C3 \%A9 -o-fim-do-ano-1.549479>. Acesso em novembro de 2013.

- O FLUMINENSE, Localização estratégica do Arco Metropolitano atrai empresas publicada em 19/02/2015. disponível em: <http://www.ofluminense.com.br/editorias/ economia/nova-fronteira-do-desenvolvimento>. Acesso em fevereiro de 2015.

- O FLUMINENSE, São Gonçalo: criação de novo porto vai gerar cerca de 20 mil empregos. 16/05/2013. Disponível em: <http://www.pmdbnacamara.org.br/noticias/ s\%C3\%A3o-gon\%C3\%A7alo-cria\%C3\%A7\%C3\%A3o-de-novo-porto-vai-gerar-cercade- 20-mil-empregos>. Acesso em janeiro de 2015. 
- 0 GLOBO. Argila ilegal extraída por milícia de Santa Cruz parava no Arco Metropolitano, informa Polícia Federal. Notícia publicada no dia 19/08/11. Disponível em: <oglobo.globo.com/rio/argila-ilegal-extraida-por-milicia-de-santa-cruz-parava-noarco-metropolitano-informa-policia-federal-2688082>. Acesso em novembro de 2013.

- OLIVEIRA, Fabrício Leal de; SANTOS, Mauro Monteiro Rego dos. Relatório sobre o Plano Diretor Urbanístico do Município de Duque de Caxias - Lei complementar № 01 de 31 de outubro de 2006. Rede de Avaliação e Capacitação para Implementação dos Diretores Participativos. 2008.

- OLIVEIRA, Francisco de. A Economia Brasileira: Crítica à Razão Dualista. Revista Estudos Cebrap $\mathrm{n}^{\circ}$ 02, 1972. Disponivel em: <http://beta.cebrap.org.br/v2/files /upload/biblioteca_virtual/a_economia_brasileira.pdf>. Acesso em fevereiro de 2015.

- OLIVEIRA, Francisco de. 0 estado e a exceção ou o estado de exceção? Revista Brasileira de Estudos Urbanos e Regionais , V. 5 , n 1, maio de 2003. Texto preparado como base para a conferência de abertura do X Encontro Nacional da Associação Nacional de Pós-Graduação e Pesquisa em Planejamento Urbano e Regional, Belo Horizonte, 26/5/2003.

- PACífiCO, Alan Gustavo Fernandes. Política, transporte aquaviário e planejamento: a gestão do sistema de circulação na Região Metropolitana do Rio de Janeiro. Rio de Janeiro. Maio de 2011. Anais do XIV Encontro Nacional da ANPUR. Disponível em: <http://www.anpur.org.br/revista/rbeur/index.php/anais/article/view/2656/2596>.

Acesso em: Maio de 2013

- PACífICO, Alan; CAPRILES, Ana Huara; TINOCO, Victor. Os Planos Diretores (19972008) da cidade de Nova lguaçu: Uma análise do (re) ordenamento territorial do município e a questão rural. 2010. Anais do XXII ENCONTRO NACIONAL DE GEOGRAFIA -UFRN. Natal, 2010. Disponível em: <http://www.cchla.ufrn.br/cnpp/pgs/anais/ Arquivos \%20GTS\%20-020recebidos\%20em\%20PDF/0S\%20PLANOS\%20DIRETORES\%20_19972008_\%20DA\%20CIDADE\%20DE\%20NOVA\%20IGUA\%C3\%87U\%20UMA\%20AN\%C3\% 81LISE\%20D0\%20_RE_\%200RDENAMENTO\%20TERRITORIAL\%20D0\%20MUNIC\%C3 \%8DPI0\%20E\%20A\%20QUEST\%C3\%830\%20RURAL.pdf>. Acesso em fevereiro de 2015.

- PIKETTY, Thomas. 0 capitalismo no século XXI. Editora: Intrínseca, 2014.

- PINTO, Amanda Rodrigues de Carvalho. Arco Metropolitano e COMPERJ: construindo novos eixos da (re) estruturação produtiva no espaço do leste metropolitano do Rio 
de Janeiro. Porto Alegre - RS, julho de 2010. Anais do XVI Encontro Nacional dos Geógrafos. Disponível em: <http://www.agb.org.br/evento/download.php?idTrabalho $=2241>$. Acesso em Maio de 2013.

- REGO, Andrea Queiros. O Arco Metropolitano e prospecções sobre as centralidades urbanas da região metropolitana do estado do Rio de Janeiro. Anais do XIV Encontro Nacional da ANPUR, 23 a 27 de Maio de 2011 Rio de Janeiro - RJ - Brasil

- REZENDE, Vera. Planejamento urbano e ideologia: quatro planos para a cidade do Rio de Janeiro. Civilização Brasileira - coleção Retrados do Brasil volume 159. Rio de Janeiro. 1982

- RIBEIRO, Gustavo. Estado prevê a construção de mais 10 BRTs até 2018. Portal do jornal O DIA, 02/11/2014 23:13:12. Disponível em: <http://odia.ig.com.br/noticia/riode-janeiro/2014-11-02/estado-preve-a-construcao-de-mais-10-brts-ate-2018.html>. Acesso em janeiro de 2015.

- RIO DE JANEIRO (governo do estado). Apresentação do Plano Diretor do Arco Metropolitano (PDAM) do Rio de Janeiro feita por Sérgio José Teixeira. Publicado pela Secretaria de Obras do Estado do Rio de Janeiro. 2009. Disponível em: < http://www.forumCOMPERJ.com.br/spic/bco_arq/MesaRedonda_Sergio\%20Teixeira\%20\%20SEDEl S.pdf>. Acesso em agosto de 2011.

- RIO DE JANEIRO (governo do estado). Arco Metropolitano do Rio de Janeiro. Apresentação do AMRJ realizada pela Secretaria de Obras do Governo do estado. em reunião do CONAMA, julho de 2011. Disponivel em: <http://www.mma.gov.br/port/conama/reuniao/dir867/ApresentARCORodv_GovRJ.pdf>. Acesso em Março de 2013

- RIO DE JANEIRO (governo do estado). Plano Diretor de Transporte Urbano (PDTU) da Região Metropolitana do Estado do Rio de Janeiro. Resultado da Pesquisa Origem/Destino. Publicado pela Companhia Estadual de Engenharia de Transporte e Logística da Secretaria de Estado de Transporte. 2005.

- RIO DE JANEIRO (governo do estado). Relatório de Impacto Ambiental (RIMA): Projeto de Implantação do Arco Metropolitano do Rio de Janeiro BR-493/RJ-109. Junho/2007. Publicado pelo Departamento de Estradas e Rodagem do Rio de Janeiro (DER-RJ). Disponível em: <http://www.firjan.org.br/site/anexos/Decisaorio/20112013/RIMA-Arco_Metropolitano.pdf>. Acesso em setembro de 2011. 
- RJTV $1^{\text {a }}$ EDIÇÃO. Motoristas reclamam da falta de sinalização no Arco Metropolitano. 10/07/2014. Disponível em: <http://globotv.globo.com/rede-globo/rjtv-1a-edicao /v/motoristas-reclamam-da-falta-de-sinalizacao-no-arco-metropolitano/3488280/>. Acesso em fevereiro de 2015.

- ROSSI, Clóvis. No mundo, 1\% mais rico terá mais do que 99\% restante, diz ONG. FOLHA DE S. PAULO. 20/01/2015 Disponivel em: <http://www1.folha.uol.com .br/mercado/2015/01/1577498-no-mundo-1-mais-rico-tera-mais-do-que-99-restantesdiz-ong.shtml>. Acesso em janeiro de 2015

- RURAL SEMANAL: Informativo da Universidade Federal Rural do Rio de Janeiro. ANO XVI. Pág. 2 Rebio- Tinguá. 08 de junho de 2009. Disponivel em: <http://www.oeco.org .br/images/docs/jul2009/ra_carioca_semanal.pdf>. Acesso em Maio de 2013.

- SAMPAIO JUNIOR, Plínio de Arruda. Desenvolvimentismo e neodesenvolvimentismo: tragédia e farsa. Revista Serviço Social \& Sociedade, $n^{\circ}$ 112, São Paulo Oct./Dec. 2012. Disponível em: <http://ref.scielo.org/dk98r5>. Acesso em fevereiro de 2015.

- SEOBRAS - Assessoria de Comunicação da Secretaria de Estado de Obras. Arco do desenvolvimento. Informativo da Secretaria de Estado de Obras - Ano 1 - Número 2 Edição Especial. Maio de 2007. Disponível em: <http://download.rj.gov.br/documentos/ 10112/243528/DLFE-29838.pdf/BoletimMaio.pdf>. Acesso em Março de 2013

- SEOBRAS - Secretaria de Estado de Obras. Obras do Arco Metropolitano chegam a 65\% da conclusão. 08 de outubro de 2013 Disponível em: <www.rj.gov.br/ web/seobras/exibeconteudo?article-id=1798017>. Acesso em novembro de 2013.

- SEOBRAS - Secretaria de Estado de Obras. Obras do Arco Metropolitano entram na reta final. 10 de outubro de 2013 Disponível em: <http://www.rj.gov.br/web/imprensa/ exibeconteudo? article-id=1798166>. Acesso em dezembro de 2013.

- Seropédica. Plano Diretor Participativo do Município de Seropédica, Lei 328/06, aprovado em 03 de dezembro de 2006

- SETRANS - Secretaria de Estado de Transportes do estado do Rio de Janeiro. AMRJ Eixo Estratégico de Integração Metropolitana. 22 de Agosto de 2007

- SISCÚ, João; PAULA, Luiz Fernando de; MICHEL, Renalt. Por que novodesenvolvimentismo? Revista de Economia Política, vol. 27 n 4 São Paulo Oct./Dec. 2007. Disponível em: <http://ref.scielo.org/6xn7cs >. Acesso em fevereiro de 2015 
- SITE DO 1BGE. Tabela 3422 - Pessoas ocupadas na semana de referência, que trabalhavam fora do domicílio e retornavam para seu domicílio diariamente, por tempo habitual de deslocamento para o trabalho - Resultados Gerais da Amostra 2010. Disponível em: <http://www.ibge.gov.br/home/pesquisa/pesquisa_google.shtm?cx=009 791019813784313549\%3Aonz63jzsr68ctcof=FORID\%3A9Ctie=1SO-8859-1 $\mathrm{ctq}=\%$ 5DMais $+\mathrm{de}+2+$ horas+todos+-+lBGECtsa=PesquisarCtsiteurl=www.ibge.gov.br\%2FCtref=Ctss $=8 \mathrm{j} 64 \mathrm{j} 2>$. Acesso em janeiro de 2015 .

- SITE dO PlANAlTo (da Presidência da República) Discurso da Presidenta da República, Dilma Rousseff, na cerimônia de abertura ao tráfego do Arco Metropolitano do Rio de Janeiro, assinatura de contrato de financiamento para abastecimento de água na Baixada Fluminense e anúncio de novos investimentos Duque de Caxias/RJ, Duque de Caxias-RJ, $1^{\circ}$ de julho de 2014. Disponível em: <http://www2.planalto.gov.br/acompanhe-o-planalto/discursos/discursos-da-presidenta/ discurso-da-presidenta-da-republica-dilma-rousseff-na-cerimonia-de-abertura-aotrafego-do-arco-metropolitano-do-rio-de-janeiro-assinatura-de-contrato-definanciamento-para-abastecimento-de-agua-na-baixada-fluminense-e-anuncio-denovos-investimentos-duque>. Acesso em janeiro de 2015.

- SITE DO TSE - Tribunal Superior Eleitoral. Consulta a prestação de contas final eleições 2006. Disponivel em: <http://www.tse.jus.br/eleicoes/eleicoes-anteriores/ eleicoes-2006/consulta-a-prestacao-de-contas-final-de-candidatos-e-comitesfinanceiros-eleicoes-2006>. Acesso em janeiro de 2015.

- STURM, Heloisa Aruth. Obra de rodovia no rio revela 70 sítios arqueológicos. Portal de notícias do jornal Estado de São Paulo. Janeiro de 2013. Disponível em: $<w w w . e s t a d a o . c o m . b r / n o t i c i a s / c i d a d e s . o b r a-d e-r o d o v i a-n o-r i o-r e v e l a-70-s i t i o s-$ arqueologicos,982876,0.htm>. Acesso em novembro de 2013.

- STURM, Heloisa Aruth. Obra de rodovia no Rio revela 70 sítios arqueológicos, 11 de janeiro de 2013. Portal de notícias do Jornal Estado de São Paulo. Disponível em: $<$ www.estadao.com.br/noticias/cidades,obra-de-rodovia-no-rio-revela-70-sitiosarqueologicos,982876,0.htm>. Acesso em setembro de 2013.

- SUPERVIA. Mapa de estações e Integrações. Disponível em: < http://www.supervia.com.br/estacoes.php>. Acesso em janeiro de 2015.

- SUWWAN Leila. Lula volta a reclamar da 'perereca' que atrasa obras . 29/07/2010 0:00, atualizado 04/11/2011. Disponível em: <http://oglobo.globo.com/politica/lulavolta-reclamar-da-perereca-que-atrasa-obras-2972821>. Acesso em novembro de 2013. 
- THOMPSON, John B. Ideologia e Cultura Moderna. Traduzido por Gilda Fantinati Caviedes. Editado pela Universidad Autónoma Metropolitana. Coyoacán, México. 1993

- THUSWOHL, Maurício. A faca e o queijo na mão 0 maior parque urbano do mundo pode se tornar também, pelo menos, o melhor do Rio de Janeiro. Publicado na Revista do Brasil da Rede Brasil Atual 04/04/2013 12:31, última modificação 22/04/2011 13:47. Disponível em: < http://www.redebrasilatual.com.br/revistas/58/afaca-e-o-queijo-na-mao/view. >. Acesso em novembro de 2013.

- TSE - Tribunal Superior Eleitoral. Consulta a prestação de contas final eleições 2006. Disponível em: <http://www.tse.jus.br/eleicoes/eleicoes-anteriores/eleicoes-2006/ consulta-a-prestacao-de-contas-final-de-candidatos-e-comites-financeiros-eleicoes2006 ultimo acesso em janeiro de 2015.

- VASQUEZ, Maria. Arco Metropolitano e COMPERJ estimulam mercado imobiliário na Baixada. 21 de Novembro de 2014. Portal PINIWEB. Disponível em: <http:// piniweb. pini.com.br/construcao/rio-de-janeiro/arco-metropolitano-e-comperj-estimulammercado-imobiliario-na-baixada-332676-1.aspx>. Acesso em janeiro de 2015.

- VEJA. Petrobras obtém licença para porto de acesso ao COMPERJ, 18/09/2012. Disponível em: < http://veja.abril.com.br/noticia/economia/petrobras-consegue-licencapara-porto-de-acesso-ao-comperj>. Acesso em janeiro de 2015.

- VILLAÇA, F. Espaço intra-urbano no Brasil. São Paulo. Studio Nobel, FAPESP, Lincoln Institute, 2001.

- VILLAÇA, Flávio. Uma contribuição para a história do planejamento urbano no brasil.. In: DEAK, C e SCHIFFER, S.R.. (Org.). In: 0 processo de urbanização no Brasil. Editora FUPAM/EDUSP São Paulo. 1999, p. 169-244. 
Universidade de São Paulo Faculdadede Arquitetura e Urbanismo Área: Planejamento Urbano e Regional

\section{Dissertação de mestrado de maio de 2015 defendida pela aluna Ticianne Ribeiro de Souza orientada pelo professor doutor João Sette Whitaker Ferreira}

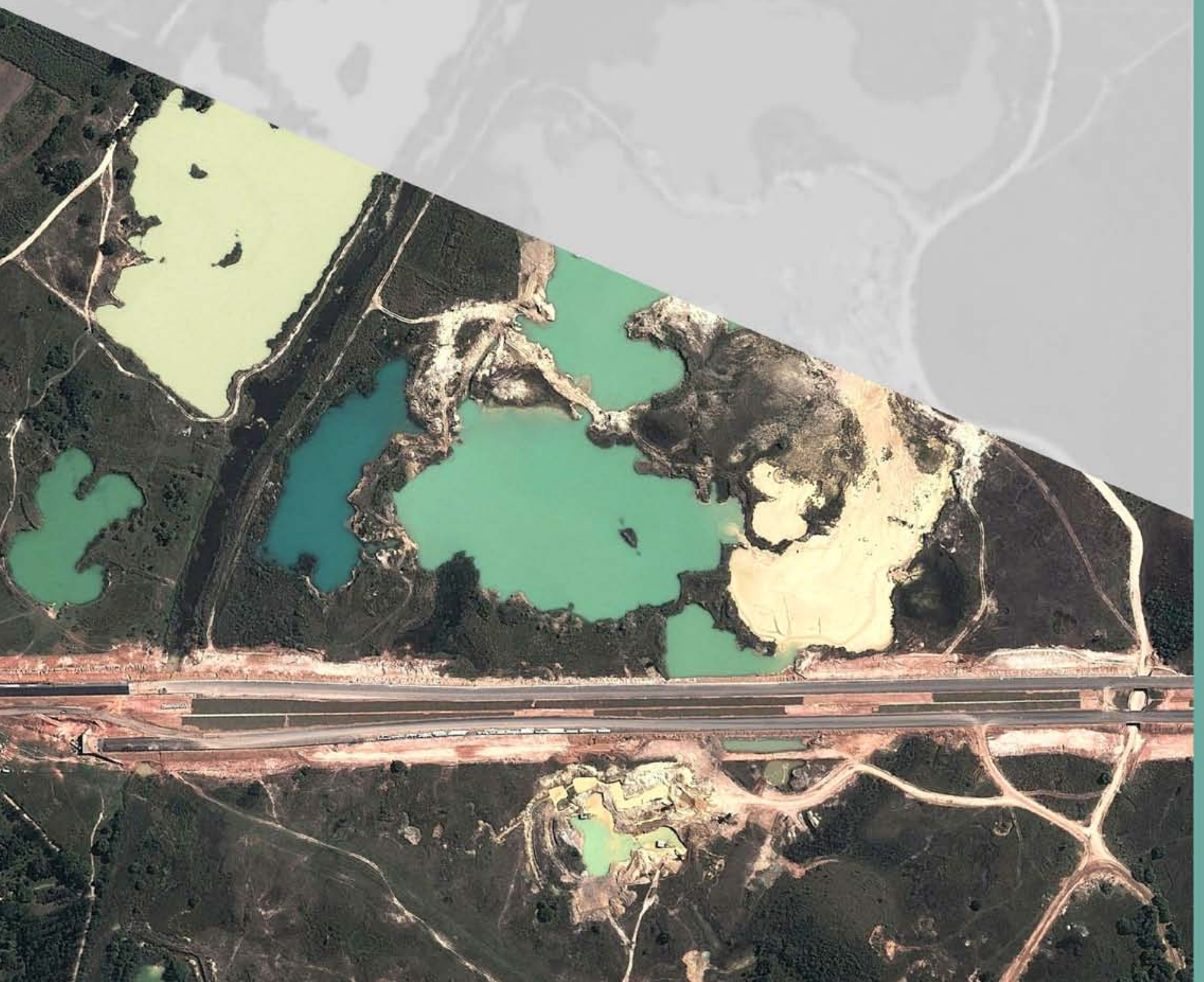

